

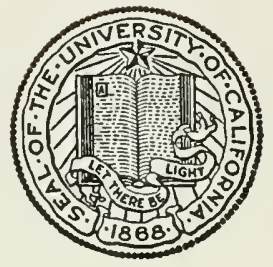

THE LIBRARY

OF

THE UNIVERSITY OF CALIFORNIA

LOS ANGELES

\section{ind home \\ LOS ANGELES COUNTY}

\section{FREE LIBRARY}

636.9 U.S. Bureau of education 14th Annual report on

introduction of domestic reindeer into Alaska. 1904.

\section{REFERENCE}




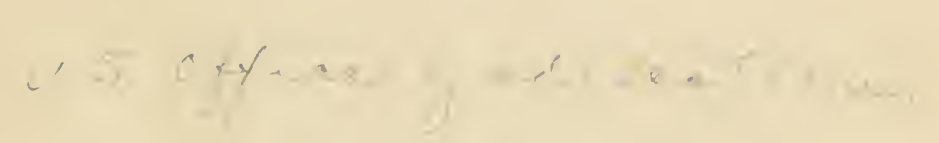







\begin{tabular}{|c|c|}
\hline $\begin{array}{c}\text { 58th Congress, } \\
\text { 3d Scssion. }\end{array}$ & SENATE. \\
\hline
\end{tabular}

\section{FOURTEENTH ANNUAL REPORT}

ON

\section{INTRODUCTION OF DOMESTIC REINDEER INTO ALASKA,}

WITH

\section{MAPS AND ILLUSTRATIONS,}

BY

SHELDON JACKSON, LL. D., GENERAL AGENT OF EDUCATION IN ALASKA.

1904.

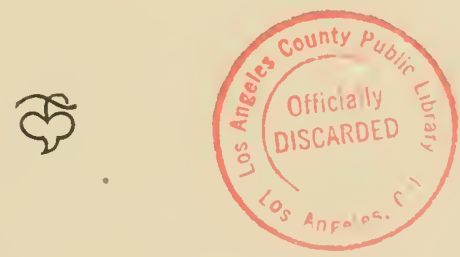

WASHINGTON: GOVERNMENT PRINTING OFFICE. 1905. 



\section{LETTER OF TRAISIITTAL.}

\section{In the Senate of the United States, December 1?, 1904.}

Resolved, That the Secretary of the Interior be directed to transmit to the Senate the report of Dr. Sheldon Jackson upon "The Introduction of Domestic Reindeer into the District of Alaska" for 1904, with maps and illustrations.

\section{Attest:}

Charles G. Bennett, Secretary, H. M. Rose, Chiej Clerk.

[Indorsement.]

Department of the Interior, December 14, 1904 .

Respectfully referred to the Commissioner of Education for immediate compliance with the request contained in the within resolution, with the return of this paper.

Thos. Ryax, Acting Secretary.

\section{Department of thie Interior,}

Bureat of Edecation, Wrashington, D. C., December 15, 1904.

SiR: I have the honor to acknowledge, by reference from you, a copy of a resolution adopted by the Senate of the United States on December 12, 1904, "directing the Secretary of the Interior to transmit to the Senate the report of Dr. Sheldon Jackson upon "The Introduction of Domestic Reindeer into the District of Alaska " for 1904."

In compliance with said resolution, I have the honor to forward herewith the report of the United States general agent for education in Alaska on the subject and covering the period named.

Very respectfully, your obedient servant,

IV. T. Harris, Cominissionem

The Secretary of tile Interior. 
Departient of the Ixterior,

Wastiugton, December 16; 1904 .

SIR: I am in receipt of Senate resolution of the 12 th instant-

That the Secretary of the Interior be directed to transmit to the Senate the report of Dr. Sheldon Iackson upon "The Introduction of Domestic Reindeer into the District of Alaska."

In response thereto, I have the honor to transmit herewith copy of a letter from the Commissioner of Education forwarding the report indicated in the above-mentioned resolution, together with its accompanying maps and illustrations.

Very respectfully,

E. A. Hitcilcocs, Secretary.

The President pro tempore. Uxited States Sexate. 


\section{TABLE OF CONTENTS.}

Action of the United States Senate........................... Page.

Action of the Secretary of the Interior.............................. 3

Letter of transmittal, Commissioner of Education to Secretary of the Interior . ..... 3

Letter of transmittal, Secretary of the Interior to the United States Senate...... . 4

Annual report of Sheldon Jackson............................... 9

Tabulated statement of reindeer imported from Siberia, with increase from

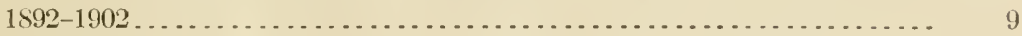

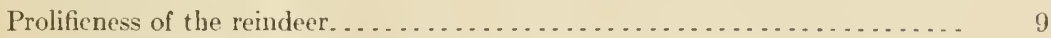

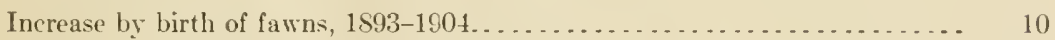

Reindeer sold, butchered, and died, 1892-1904.................... 10

Tabulated statement showing proportion of sexes in the reindeer herds. . . . . . 10

Loan of reindeer to religious denominations..................... 11

Tabulated statement of reindeer loaned....................... 12

Reindeer apprentices......................................... 13

Tabulated statement of apprentices, with their holdings. . . . . . . . . . . . 16

Establishment of new reindeer stations......................... 17

Proposed new stations in near future ........................ 18

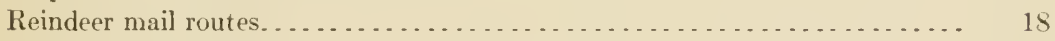

Finn teachers and herders ........................................ 18

Chain of relay stations.................................... 15

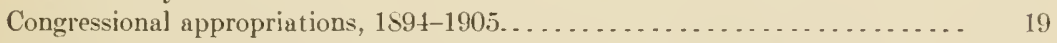

Expenditure of appropriation for the year ending June 30, 1904 . . . . . . . . 19

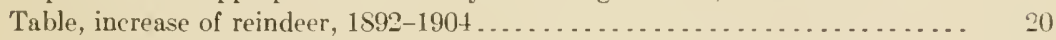

Table of ownership of relndeer............................ 20

Table, reindeer belonging to the Gorernment ...................... 20

Table, individual ownership of reindeer, 1904................... 21

Personnel........................................... 22

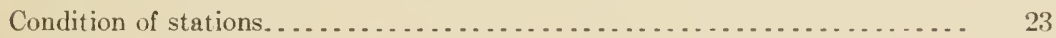

Cruise of William Hamilton, Ph. D . . . . . . . . . . . . . . . . . . . . . . . . 26

Cooperation of Treasury Department......................... 28

\section{APPENDIX.}

Request to the Secretary of the Treasury for transportation of agents of the Bureau of Education on revenue cutters. . . . . . . . . . . . . . . . . . . . . . . .

The Secretary of the Treasury grants permission for the agents of the Bureau of

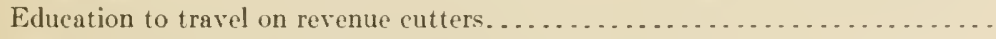

Letters of instruction to assistant agent of education in Alaska..............

Itinerary of William Hamilton, $\mathrm{Ph}$. D., assistant agent of education in Alaska..... 
Extracts from daily journal from Unalakleet to Bethel and return, Norember and December, 1903, by Carl O. Lind, I1. D., general superintendent, central division. . Memoranda concerning reindeer route between Bethel and Copper Center, Alaska, by the United States Geological Sursey, May 3, 1901 . . . . . . . . . . . . . . . . . Annual report:

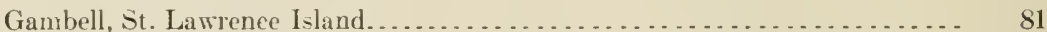

Eaton reindeer station .... . . . . . . . . . . . . . . . . . . . . . . . . . . 95

Cape Prince of Wales reindeer station, Wales...................... 106

Golofnin reindeer station................................. 114

Bethel reindeér station ..................................... 115

Kotzebue reindeer station ................................ 116

Reindeer in Alaska, by Prof. C. C. Georgeson, special agent in charge Alaska agrieultural experiment stations (reprinted from Professor Georgeson's report on reindeer and caribou to the Department of Agriculture) ..................

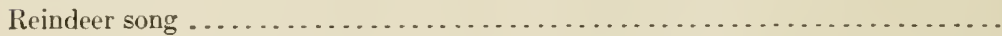




\section{ILLLSTRATIONS.}

\begin{tabular}{|c|c|c|}
\hline Subject. & Pliotographer. & No. \\
\hline Chilkat canoe under sail ................. & Blankenberg...... & \\
\hline 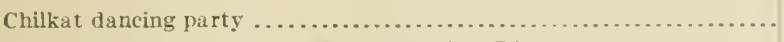 & $\ldots$. do $\ldots . . . . . . .$. & 2 \\
\hline Episcopal Church, st. James Mission, Yukon River ..... & Wm. Hamilton.. & 3 \\
\hline Episcopal Home, St.James Mission, Yukon River........ & .... do.......... & 4 \\
\hline Erosion of the banks of the Yukon Rirer................ & $\ldots$. do........ & \\
\hline Eskimo child ren, Golofnin Home.................. & Kinne.......... & \\
\hline Eskimo children, Cnalakleet ...................... & & \\
\hline Eskimo school boys, kyak racing (noon recess) ...................... & ...... & \\
\hline Eskimo orphans, Norwegian Evangelical Lutheran Mission .......... & Tappan Adn & \\
\hline 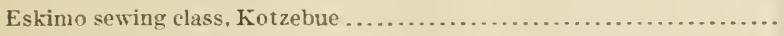 & & 10 \\
\hline Fairbanks, cit 5 hall. ................ & Wn. Hanilton. & 11 \\
\hline Fairbanks, main street ............... & $\ldots$. do $\ldots . . . \cdots \cdot$. & 12 \\
\hline Finlander, teachers and herders...... & & 13 \\
\hline Fort Gibbon, Yukon River..................... & Wm. Hamilton.. & 14 \\
\hline Golofnin Home.................................. & Kinne ........... & 15 \\
\hline 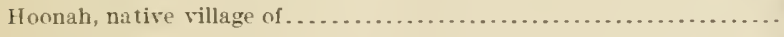 & & 16 \\
\hline Inlian houses on the Yukon............................. & Wm. Hamilton.... & 17 \\
\hline 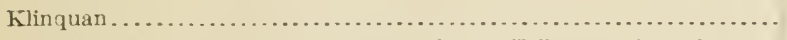 & n................. & 18 \\
\hline Presbyterian Industrial School, Sitka, Wm. A. Kelly, superintendent.... & E. W. Merrill ........ & 19 \\
\hline 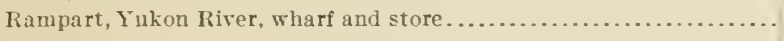 & Wm. Hamilton..... & 20 \\
\hline Reindeer: & & \\
\hline Arrival of Laplanders at Bethel.. & & \\
\hline Herd at Golofnin Bay ....................... & Kinne ..... & 22 \\
\hline Herd at Inalakleet ............................... & & 23 \\
\hline Herders' houses near Bethel, Kuskokwim Valley............. & & 24 \\
\hline 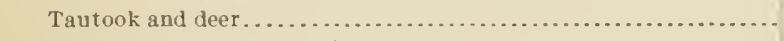 & Kinne...... & 2 \\
\hline Wasely and Tommy skinning reindeer............. & & 26 \\
\hline 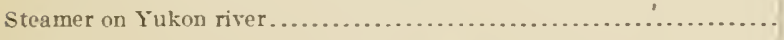 & Wm. Hamilton.. & 27 \\
\hline 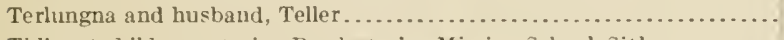 & Tappan Adney... & \\
\hline Thlinget child ren entering Presbyterian Mission School, Sitka.. & & 29 \\
\hline Thlinget child ren trained in Sitka school....................... & & 30 \\
\hline 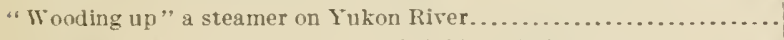 & Wm. Hamilton.. & 31 \\
\hline 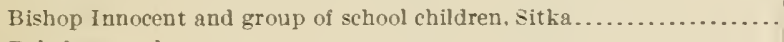 & & 32 \\
\hline 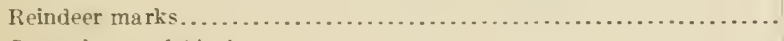 & & 33,34 \\
\hline 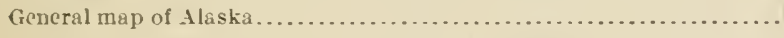 & & P. 2 \\
\hline ketch map of reindeer stations and routes of trarel............... & & Y. 2 \\
\hline
\end{tabular}





\title{
FOURTEENTH ANNUAL REPORT
}

\author{
(I) TIE
}

\section{INTRODUCTION OF DOMESTIC REINDEER INTO ALASKA.}

\author{
DEPARTMENT OF TIE INTERIOR, \\ Bureau of Educition, Alaska Division, \\ Washington, D. C., December 1in, 1304 .
}

SIR: I have the honor to submit the fourteenth annual report on the introduction of reindeer into Alaska. Anmual reports more or less full have been received from all the stations. These reports show that on the 30 th of June, 1904 , there were $S, 1 S 9$ domestic reindeer in Alaska, of which number 2,28t were fawns, born during the spring of this year.

These 8,189 reindeer are distributed in 12 herds at 11 central stations.

A review of the statistical tables is full of encouragement. Table I shows in detail that between the years 1892 and 19021,280 reindeer were imported from Siberia into Alaska; and that from these imported deer and their fawns, commeneing with 143 in 1892 , the deer have increased in 1904 to a grand total of 8,189 .

TABLE I.-Increase from 1892 to $190 \%$.

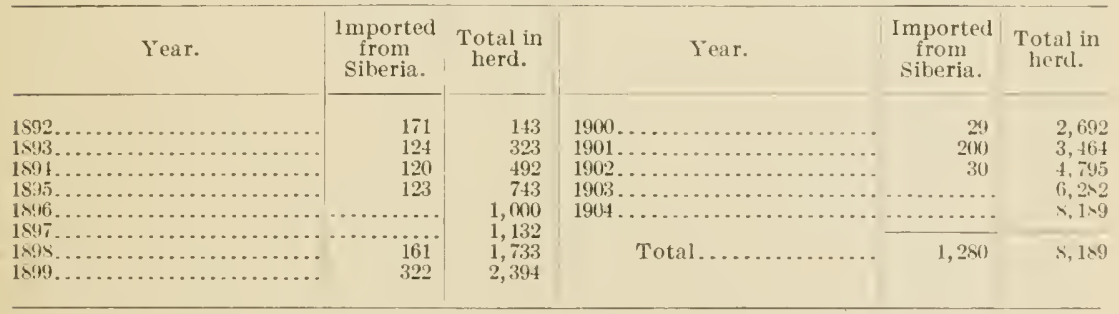

Table II shows the prolifieness of the reindeer. The statistics corering the years 1892 to 1904 show that the ilicrease of the reindeer herds progresses at an average rate of 45 per cent per anmum, doubling the total once in $2 \frac{1}{3}$ years. Thus in 1907 the total number of reindeer in Alaska should be 16,000; in 1909, 32,000; in 1912, 64,000 ; in 1915, 12S,000. The increase by birth of 1,877 last year made a good showing; the increase of $2.2 S 4$ this present year makes a better snowing, and if the same percentage of increase is continued 
until 1915, the number of fawns born that year should number approxinately over 38,000 . This ever-inereasing annual birth of fawns will settle farorably many important questions in the development of Alaska.

TABLE 1I.-Inerease of fauns, 1893 to 1904.

\begin{tabular}{|c|c|c|c|}
\hline Year. & $\begin{array}{l}\text { Balance } \\
\text { from } \\
\text { previous } \\
\text { year. }\end{array}$ & $\begin{array}{l}\text { Fawns } \\
\text { surviring. }\end{array}$ & $\begin{array}{c}\text { Per cent of } \\
\text { inerease of } \\
\text { herds by } \\
\text { fawns. }\end{array}$ \\
\hline 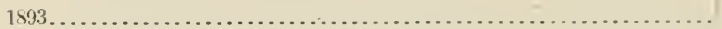 & 143 & 79 & 55 \\
\hline 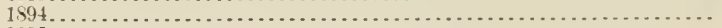 & 323 & 145 & 41 \\
\hline 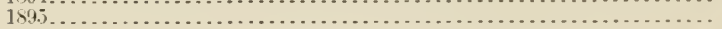 & 492 & 276 & 56 \\
\hline 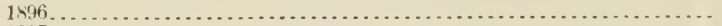 & $i 43$ & 357 & 49 \\
\hline 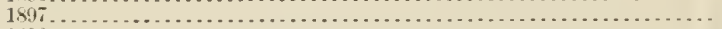 & 1,000 & 466 & 46 \\
\hline 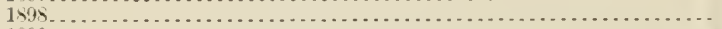 & 1,132 & 625 & $5 \overline{5}$ \\
\hline 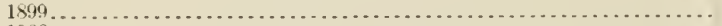 & 1,733 & 638 & 37 \\
\hline 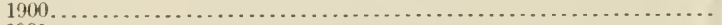 & 2,394 & 756 & 32 \\
\hline 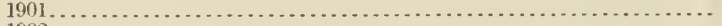 & 2,692 & 1,110 & $\$ 1$ \\
\hline 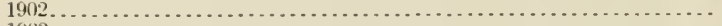 & 3,464 & 1,654 & 45 \\
\hline 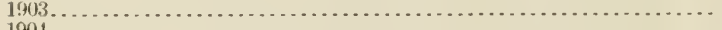 & 4,795 & 1,87 & 40 \\
\hline 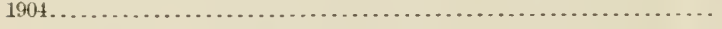 & 6,282 & 2,284 & 36 \\
\hline Total fawns surviving........... & & 10,267 & \\
\hline
\end{tabular}

Arerage annual increase of herds by fawns, 1893-1904, t5 per cent.

Those who have ioans of reindeer are allowed, under the supervision of the local agent in charge of the reindeer, to kill for their own use or sell to outsiders surplus male deer from their own herds. This method enables a herder to provide a support for his family. No female deer are allowed either to be killed or sold, except under special circumstances, when they can be sold to the Government for the establishment of new herds, without impairing the productivity of the herd.

TABLE III.-Number of reindeer sold, butchered, or died, 1892 to 1904.

\begin{tabular}{|c|c|}
\hline 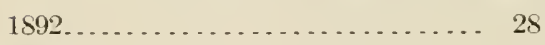 & 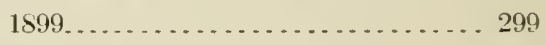 \\
\hline$\ldots \ldots \ldots \ldots$ & $1900 \ldots \ldots \ldots \ldots \ldots$. \\
\hline . & $1901 \ldots \ldots \ldots \ldots . . . \ldots . . . .$. \\
\hline ........ 148 & 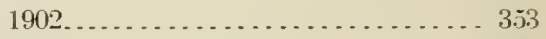 \\
\hline .. 100 & $1903 \ldots$ \\
\hline . . . ."1334 & $1904 \ldots \ldots \ldots . . .6 . . .6$ \\
\hline
\end{tabular}

TABLE IV. - Shouing sex of reindeer in herds, 190!.

\begin{tabular}{|c|c|c|c|c|c|c|c|}
\hline \multirow{2}{*}{ Station. } & \multicolumn{3}{|c|}{ Adults. } & \multicolumn{3}{|c|}{ Fawns, 1904.} & \multirow{2}{*}{$\begin{array}{l}\text { Totalat } \\
\text { station. }\end{array}$} \\
\hline & Male. & Female. & Total. & Male. & Female. & Total. & \\
\hline 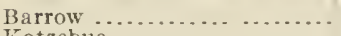 & & & . & & & & 599 \\
\hline 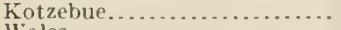 & & $\cdots$ & 482 & 112 & 120 & 232 & 71 \\
\hline 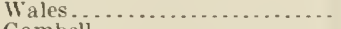 & 402 & 717 & 1,119 & 195 & 171 & 369 & 1,46 \\
\hline Gambell..................... & 60 & 87 & 147 & & 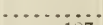 & 65 & 212 \\
\hline 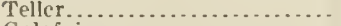 & 225 & 469 & 694 & 192 & 157 & 379 & $1,0 \%$ \\
\hline 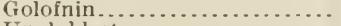 & 257 & 382 & 639 & $\ldots$ & . & 285 & 92 \\
\hline I'nalakleet ................... & 297 & 403 & 700 & 14.5 & 139 & $2>\frac{1}{2}$ & 93 \\
\hline Faton $\ldots \ldots \ldots \ldots \ldots \ldots$ & 249 & 385 & 637 & $15 \pi$ & 140 & 297 & 931 \\
\hline 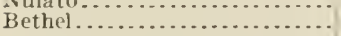 & @so & 459 & 739 & 152 & 155 & $30 \pi$ & 1,040 \\
\hline Total............. & 1,770 & 2,905 & 5,307 & 956 & 912 & 2,204 & $8,18 ?$ \\
\hline
\end{tabular}

a 246 of these deer xere killed in the relief expedition to the whalers at Point Barrow. 
Table IV shows that the number of male deer sold is not in excess of the efficieney of the herd.

In the establishment of reindeer stations in eentral and northwestern Alaska in 1892, the Bureau of Education found that in order to secure the best results and greatest permanency to the herds and largest suecess among the natives it was necessary to avail itself of the existing mission stations.

These mission stations have been located, in the light of a great deal of experience, at such places as furnish natural centers for the native population and at the same time afford the best facilities for communication with the United States in the short summer season.

They not only have the adrantage of being located in important centers of the native population in the north and west, but they bring with them certain other advantages which the Government may use for its purposes of instrueting the natires in the English language and in the arts of civilized life. In the first place, the mission station is a very effective center for the spread of the use of the English language among the natives, edueating not only the children who come to its sehools, but also the adult population attending its religious services or coming into any business relation with it whatever.

At each mission station there is constantly going on a process of selecting the trustworthy natives, those ambitious to learn the eivilization of the white men, those ambitious to hold and inerease property. The missions are able at any time to furnish a list of the natives in their vicinities noted for good character. At each of these stations 20 or 30 youth, selected from a village population of 300 or more, can be put in training as herdsmen and teamsters. No matter how large the Government appropriation should be, it would be necessary to connect the reindeer instruction and the establishment of permanent herds in northwest Alaska with these missionary stations.

In view of the above advantages, small herds of 100 reindeer each have been loaned to several stations belonging to different denominations as a Government aid in the nature of an outfit of industrial apparatus. The report of the Indian Bureau shows that the United States Government furnished 10,000 head of stock for the period of 1890-1S96 for one Indian ageney (the Blackfeet), and that seeds, implements, stock, wagons, harness, in large amounts, have been furnished to other ageneies. These donations are certainly more justifiable than donations made to prevent the savage peoples from starring, for they are given, in the form of apparatus, for the instruetion of these peoples in the industrial arts and in the practice of thrift. All these things prevent starration. Just as in the agricultural colleges of the sereral States, the Government money is used to pay for the stock of the model farm, which is used as the apparatus for the instruction of the pupils, so the reindeer herd is used as apparatus 
loaned to the missionary stations for the purpose of instruction of the natives. But an average of five year's' apprenticeship is needed for the full training of apprentices in the management of reindeer.

These herds have been loaned on the condition that they be used as apparatus for the instruction of natives in the art of herding deer and training them to harness, and on condition that after five years the Government may take from the herd a number of deer in good condition, equal to the original number furnished, the stations retaining the increase.

Reindeer loaned.

\begin{tabular}{|c|c|c|c|}
\hline Station. & $\begin{array}{l}\text { Number } \\
\text { loaned. }\end{array}$ & When loaned. & When due. \\
\hline Wrales (Congregational)..... & 118 & Alug., $\quad 1894$ & Gift. \\
\hline Golofnin Bay (Swedish Lutheran) .... & 50 & Jan. 16,1896 & Returned. \\
\hline 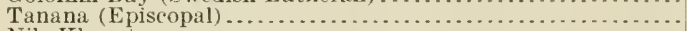 & 50 & .... do....... & Do. \\
\hline Nils Klemetsen ........... & 100 & July 1,1902 & July $30,1907$. \\
\hline 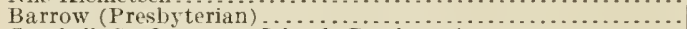 & 100 & Sept., 1895 & Returned. \\
\hline 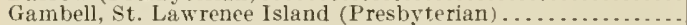 & 70 & July, $\quad 1900$ & June $30,1905$. \\
\hline Teller (Norwegian Lutheran) & 100 & Sept. 1,1900 & Aug. 31, 1905 \\
\hline 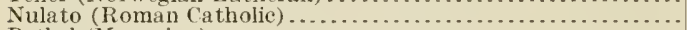 & 100 & Mlar., $\quad 1901$ & Mar., 1906. \\
\hline 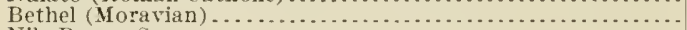 & 88 & Feb. 26, 1901 & Feb., 1906. \\
\hline 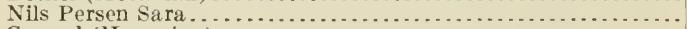 & 100 & July, $\quad 1901$ & June 30,1906 \\
\hline Carmel (Moravian)..... & 88 & Feb. 26,1901 & Fel)., 1901. \\
\hline Per $\mathbf{~}$. Spein ........ & 100 & July, $\quad 1901$ & June, 1906. \\
\hline Kotzebue (Friends). & 95 & Sept. 2,1901 & Sept., 1906. \\
\hline Alfred S. Nilina............. & 99 & July, & June $30,1906$. \\
\hline 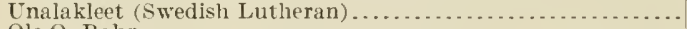 & 100 & July $\quad 1,1903$ & June $30,190 \mathrm{~s}$ \\
\hline 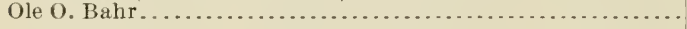 & 100 & July $\quad 1,1901$ & June $30,1906$. \\
\hline
\end{tabular}

\section{REINDEER AN IMPORTANT FACTOR IN THE CIVILIZATION OF THE}

ESKIMOS.

The President in his recent message to Congress calling attention to the changed conditions which have come to the natives of Alaska with the advent of large numbers of white men in their country emphasizes their need of attention, especially in the way of industrial schools and hospitals.

This raises the question, how can the natives of Alaska be made valuable helpers and assistants in the development of the country by white men now there engaged in mining, and in doing so provide a good support for themselves and families?

Any successful method of accomplishing such desirable results must keep clearly in view the aim to prepare the natives to become a help to the immigrants who come from the States for the purpose of conducting mining operations. There are two things which the native may be taught to do which wili enable him to help the immigrant: First, he may be taught how to create a supply of cheap food; second, he may be taught how to supply a cheap transportation by means of reindeer. It is known that in the river valleys certain garden vegetables may be produced in large quantities eren up to the Arctic Circle and for 50 miles beyond it. The native knows how 
to take fish from the rivers and from the sea for his family use, and with proper training can be made an equally suecessful fisherman for the market.

The experience of the past twelve years las proved that he can also become skillful in raising reindeer for food. With the cradual disappearance of the caribou and moose in sections of Alaska, and the difficulty and expense of bringing beef and mutton from the states to the inland mining camps, it is of great importance that the Eskimo be trained to raise reindeer with which to supply the immigrant miner with fresh meat.

When in the winter of $1597-98400$ sailors engaged in whaling were imprisoned in the ice off Point Barrow and in danger of perishing with scurvy and starration, they were saved by the reindeer herd driven by Eskimos from Bering strait to Point Barrow and slaughtered for food.

Already 65 Eskimos (nearly all of whom have served a five years' apprenticeship learning the business) own 2.779 deer. Reindeer multiply rapidly. From the 1,2s0 Siberian reindeer imported between 1.892 and 1903 and from their natural increase 10,267 fawns have been born in Alaska.

The Eskimo has always been skillful in driving dogs, and now, under instruction, he is proving equally skillful in driving reindeer, and upon various occasions, when the opportunity has offered, has invariably demonstrated his ability to successfully transport with reindeer mails, freight, and passengers between mining camps. Under contract with the Post-Office Department the United States mail has been carried by reindeer teams on the four postal routes between St. Michael and Kotzebue, Eaton and Nome, Teller and Deering, and Kotzebue and Point Barrow (this latter being the most northern mail route in the world). With the increase of reindeer and trained native teamsters such service will become universal in northern and central Alaskia.

When the native has thus become useful to the white man by supplying the markets with fish and fresh meat, and when he has become herdsman and teamster with reindeer, he has not only assisted the white man in solving the problem of turning to the use of civilization the vast territory of Alaska, but he has also solved his own problem. If useful to the white man as a self-respecting and industrious citizen. he has become a permanent stay and prop to civilization, and his future is provided for.

The conclusion resulting from this is that the native must be taught in school how to speak English, and be trained in industrial schools in the simple arts of agriculture and of reindeer herding and teaming with a view to provide cheap food and cheap transportation for the use of the immigrant. 
To accomplish such training it is important that an increased number of small industrial schools shall be established at centers convenient to the native population.

$\Lambda$ these schools, in addition to elementary instruction in the English language, there should be given special instruction $(a)$ in making fish nets and in adopting improved methods of catching and preparing fish for family use and for sale; $(b)$ in the care and raising of reindeer, and in their breaking in and use in transportation; $(c)$ wherever the conditions of soil and climate will allow, in the cultivavation of hardy regetables.

While destitution is not at present rery widespread among the natives, yet it may be wise to have at each of these schools a small supply of food and clothing to afford temporary relief for very special cases of destitution. The principal of the school can be made a bonded officer of the Government and be charged with the care and distribution of such supplies without additional expense to the Government.

The Secretary of the Interior has again and again called the attention of Congress to the need of hospitals for the natives. These should be provided for at once. But when the hospitals are erected they will necessarily be accessible to comparatively limited areas. In addition to the proposed hospitals, very important service may be rendered and a greatly increased number of natives benefited by the employment of a physician in connection with each of the industrial schools. This plan has been in successful operation at several of the missionary stations in Alaska.

\section{REINDEER AND THE MINER.}

While the original purpose in the introduction of domestic reindeer into Alaska was to assist in the civilization of the natives and to help them to a better and more certain method of gaining a livelihood, yet the reindeer will prove equally important to the white man who may seek a home or engage in business in subarctic Alaska.

In the development of the rich mineral resources of that region the miner will find the reindeer and the Eskimo herder and teamster the connecting link between himself and the resources of nature-for his comfort and for his profit.

The ordinary white man is unwilling to undergo the drudgery of herding in that rigorous climate, and unwilling to work for the small compensation that is paid for such services. He can do better. His directive ability can be more profitably employed as merchant and manager of transportation, in employing and directing the trained Eskimo herders and teamsters.

With the increase of domestic reindeer in Alaska it will become possible for white men to own large herds, but the men that will do 
the herding and teaming will always be Eskimos, Laplanders, and Finlanders.

Thus the Eskimo, trained as herder or teamster, will prove valuable to the white man, and the white man in turn, as director and employer, will be raluable to the native.

Already the reindeer have given evidence of some of the ways in which they will prove an important factor in the development of the great north region.

As the reindeer is the only draft animal in arctic regions that is able to secure its own food while on a journey, the question of cheapness and speed will bring it into universal use.

They will carry passengers, mails, and freight between the mining camps and the trunk railways that will yet penetrate Alaska.

Now, the object of the reindeer enterprise is to accomplish this very purpose-namely, to convert the nomadic tribes of fishers and hunters in northwestern and central Alaska into raisers of reindeer; to change their occupation from the precarious pursuits of hunting wild animals and of taking fish from the waters of inland rivers to that of herders and teamsters; to elevate a people who in their wild, uncivilized state are the prey of unscrupulous, transient immigrants into a self-supporting race, not enemies but friendly allies and auxiliaries of the white man.

\section{REINDEER APPRENTICES.}

To fit the natives to become the helpers of the white man in the development of Alaska, the Government, through the Bureau of Education, has established in a number of places the training of young men in the raising, care, and management of reindeer as an industrial branch of the public school system of central and northern Alaska.

Bright young Eskimo men are selected and placed in these schools for a period of five rears under skillful Finn or Lapp instructors who drill them in the business. The apprentice during his five years of training is supported and clothed either by the Gorernment, the mission station, or a herder, according as he is employed by one or the other of these parties. In addition to food and clothing he is allowed the loan of two female deer per year upon which he may place his mark and consider the herd as his private property, subject to Gorernment control with reference to slaughter and sale. After the close of the second year of apprenticeship these deer are retained in the general herd under the care of an experienced Lapp or Finn and under the superrision of the mission station with which the herder is connected. This general supervision extends for twenty years. This extended period of tutelage is to create in the roung Eskimos thrift and the reindeer habit-to teach them to preserve and accumulate their herds, to keep them in groups for self-protection, encouragement, and emulation, 
and to exercise a paternal oversight over them in their new civilization.

II, however, during this period of twenty years the herder indulges in a protracted season of intemperance, abandons or otherwise fails to care for the herd, the Govermment is at liberty to dispossess him of its loan and the increase thereof and reloans the same to other parties who may give evidence of making a better use of the loan. This works no injustice to the individual herder, as the herder during the five years of his apprenticeship has had from the Govermment or missionary station regular food and substantial clothing, far better than he would have had if he had remained away from the herd. The same is true after the years of his apprenticeship are ended; he will continue to receive food and clothing from his herd instead of the Govermment. When an apprentice becomes a herder he is expected to secure the support of himself and family by the sale of surplus male deer to butchers and miners, and expected to train some other apprentice. In most cases this subapprentice is some nember of the herder's family. There are now 39 Eskimo herders who have served an apprenticeship of five years or more supported at the different stations. The herders have 61 Eskimos now under training as apprentices who do not own any deer. As many of the herders have families of growing children and relatives living with them, it is estimated that at least 400 natives are now obtaining their support from the deer.

The reindeer are held by their owners subject to the conditions of a written agreement with the United States which prevents the slaughter of the female deer for meat and the sale of female deer to any other party than the Government, and insures the instruction of apprentices in the arts of training and breaking the deer to harness. Surplus male deer are allowed to be sold to miners or others for nieat or transportation purposes.

Number of apprentices, with their holdingls.

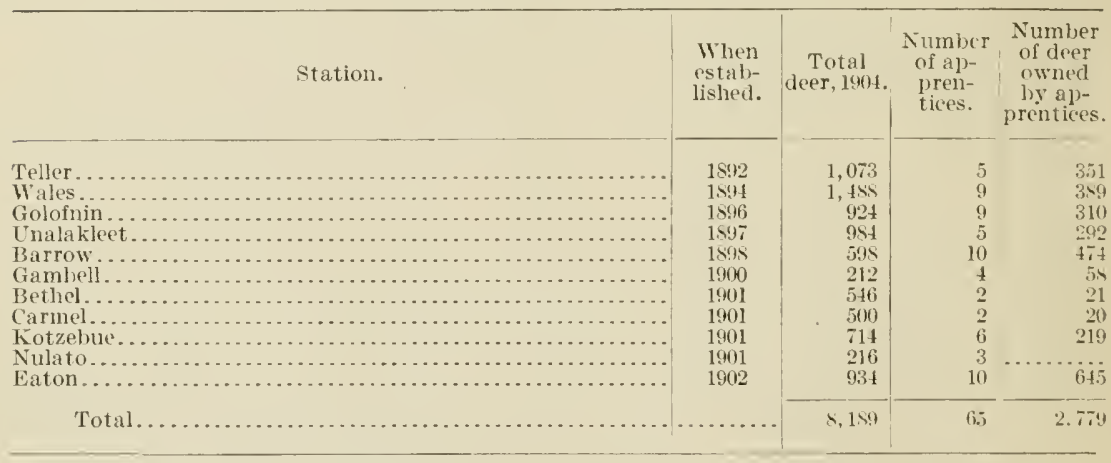


NEW REINDEER STATIONS ESTABLISIIED.

In view of the failure of the ammual mail and food supply to reach Barrow in the fall of 1903 , it was decided to establish an additional reindeer station at the southern edge of the summer ice fields om the Arctic coast, and Wainwright Inlet was selected. Mhlook with 140 reindeer, Shoudla with 5.5, and Paneoneo with 25, Eskino herders at Point Barrow, with a total of 220 reindeer, have been sent to stock the new station. Mr. John H. Kilbuck, of Kansas, who had been fifteen years in Alaska, was placed in charge of the new station, and last summer building material and supplies were forwarded to that point. Building material was also forwarded for a new reindeer station to be established in the neighborhood of Hope (Kivilenya River), midway between Bering Strait and Point Barrow. Electoona with 113 reindeer, and Otpelle with 22, hare been sent to open this station.

The above stations will be of much assistance in operating the winter reindeer mail route, which has been established by the PostOffice Depaŕtment at Washington, between Kotzebue and Barrow, a round trip of about 1,500 miles above the Aretic Circle. The reindeer herd at Barrow was divided into three herds-one remaining at Barrow, the second being sent to Wainwright, and the third to Point Hope, the three places being on the Arctic coast.

With the rapid increase of the herds, arrangements have been consummated for the establishment of two additional central stations: the one at Bettles, in the interior of Alaska, nortl of the Arctic Circle, on the Koyukuk, the great northern tributary of the Yukon River, 720 miles to the eastward of Nome, and the other at Copper C'enter, about 105 miles north of Vaklez, on Prince William Sound. Mr. W. T. Lopp, superintendent of the northwestern section of the reindeer herds in Alaska, will take charge of the driving of the herd of 300 reindeer this winter $(1904-5)$ from Lnalaklik to Bettles, in which he will be assisted by three Finlanders (Messrs. Adolph Saari, Marelius Jensen, and Charlie Raisanen) and two or three trained Eskimo herders. Mr. D. W. Cram, of Minnesota, has been appointed teacher of the school at Bettles and superintendent of the reindeer herd at that place. The herd of 300 head for Copper Center will be driven from Bethel, in the Kuskokwim Valley, in charge of Mr. H. E. Redmyer, assisted by Finlanders Messrs. Louis Karbum, Erick Lampela, and John Wuori, Peter J. Hatta (Lapp), and Eskimo drivers.

To replace the reindeer sent from Unalakleet to the new station at Bettles, Mr. W. T. Lopp drove 300 reindeer to Unalakleet from Wales and Teller.

S. Doe. $61,58-3-2$ 
And to replace the deer sent from Bethel on the Kuskokwim River to establish a herd at Copper Center, Dr. C. O. Lind will transfer 330 head of deer from Cnalakleet to Bethel.

LIST OF REINDEER STATIONS TIIAT SIIULLD BE ESTABLISIIED DUTING 1905.

North of the Aretic Circle, Point Lay, Thetis Coal Mines, and Corwin Lagoon. South of the Aretic Circle, Deering. On the Yukon River, Tanana, Anvik, and Koserefski. On the Kuskokwim River, Quinhagak and Ougavik.

REINDEER MAIL ROUTES.

During the past winter the United States mail was carried by reindeer between Teller and Wales, a round trip of 140 miles, and between Teller and Igloo, also a round trip of about 140 miles.

Fourteen round trips to Wales and ten round trips to Igloo, aggregating 3,300 miles, were made during last winter on these two routes. A winter mail was also carried by reindeer north of the Arctic Circle between Kotzebue and Barrow, a round distance of 1,500 miles. These three mail routes are all in northwest Alaska. Freighting with the reindeer was done at several of the mission stations, for miners and others, and a few of the miners purchased and used reindeer for packing and sledding on their prospecting expeditions.

$\mathrm{Mr}$. William $\mathrm{T}$. Lopp, formerly a Congregational missionary at Wales, has been appointed superintendent of the reindeer herds from Barrow south to Gambell, on St. Lawrence Island.

\section{FINN TEACIIERS ANII HERDERS.}

As the Finlanders are considered the most intelligent reindeer breeders in the world, arrangements were consummated last spring with Mr. J. H. Jasberg (himself a Finn), of Hancock, Mich., to select and hire from the large Finn population in northern Michigan eight men thoroughly aequainted with the management and care of reindeer. These men were distributed as follows: Messr's. Saari, Jensen, and Raisanen for Bettles; Messrs. Karbum, Lampela, and Wrori for Copper Center, and Messrs. Albert Lahti and Sigfrid Sotka for Gambell, St. Lawrence Island.

\section{CIIAINS OF STATIONS.}

As early as 1896 it began to be evident that in the distribution of the reindeer it was important that there should be chains of herding stations, about 100 miles apart, with intermediate relay stations along important lines of travel for reaching the native population. Map No. 2 shows the progress that has already been made 
in that direction. The full circles represent existing reindeer stations with the date of their establishment. Half circles represent proposed stations in the near future. The first important line was from Cape Prince of Wales east along the northern coast of Bering Sea to Unalakleet, 350 miles; the second from Cape Prince of Wales north along the Arctic Ocean to Point Barrow, s.50 miles; the third was from Unalakleet south along the east coast of Bering Sea to Carmel on the Nushagak River, 300 miles; the fourth from Lnalakleet eastward to Nulato in the Iukon Valley, 1.50 miles (this line will be extended from Nulato up the river 705 miles to Fort Yukon): the fifth from Kotzebue Sound eastward to Bettles on the Koyukuk River, 400 miles; and the sixth from Quinhagak at the mouth of the Kuskokwim River eastward to Copper Center north of Prince William Sound, between 400 and 500 nilles. These trunk lines of reindeer trarel will furnish increased facilities for reaching and civilizing the native population and for the white men in the development of the resources of the country.

Congressional appropriations for the introduction of domestic reindeer into Alasta from Siberia.

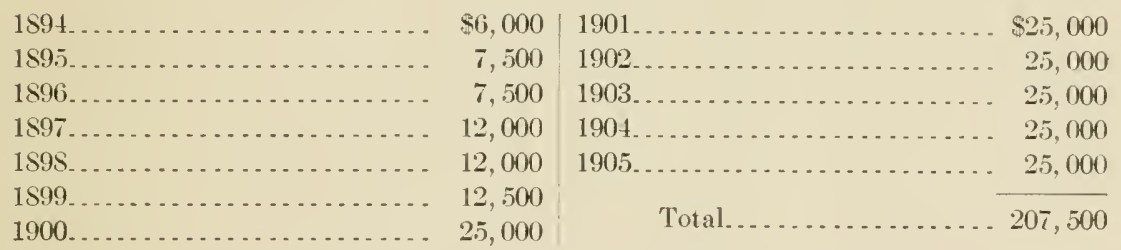

Expenditure of appropriation, "Reindeer for Alaska," 1904.

Amount appropriated. $\$ 25,000.00$

Salaries of six employees

$8,624.29$

Supplies for stations.

$5,515.70$

Freight.

778. 21

Traveling expenses

$2,246.96$

Printing of annual report (1,000 copies) 547.98

Plıotographs and electros for report.

2S. 70

Purchase of 265 deer in Alaska, at \$25 per head.

Outstanding liabilities. ................................. 550.00

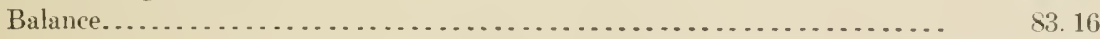

Total

$25,000.00$ 
Increase of reinder from 1892 to $1904_{-1}$.

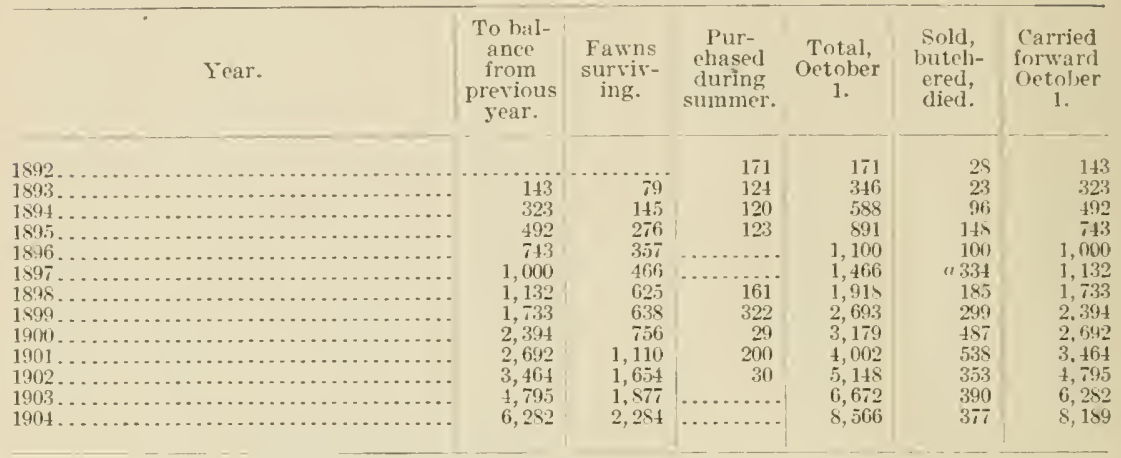

a 246 deer were killed in the relief expedition to the whalers at Point Barrow.

Table shouing ounership of reindeer.

\begin{tabular}{|c|c|c|c|c|}
\hline Name of station. & $\begin{array}{l}\text { Govern- } \\
\text { ment. }\end{array}$ & Station. & $\begin{array}{l}\text { Appren- } \\
\text { tices and } \\
\text { herders. }\end{array}$ & Total. \\
\hline Barrow..... & 95 & 29 & 119 & 243 \\
\hline Wainwright . . . . . . . . . & & & 220 & 220 \\
\hline 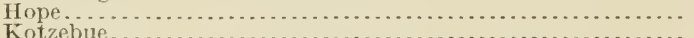 & & & 135 & $\frac{135}{i 14}$ \\
\hline 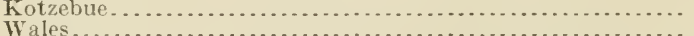 & 194 & $\frac{144}{939}$ & $\frac{-1376}{389}$. & $-1,485$ \\
\hline Gambell................. & 70 & 84 & 58 & 212 \\
\hline . & $50 \mathrm{~s}$ & 214 & 351 & 1,073 \\
\hline Goloinin & 121 & 370 & 433 & 921 \\
\hline Unalaklik.. & 512 & & 472 & 084 \\
\hline Eaton................. & 163 & 126 & 645 & 934 \\
\hline Nulato................. & 100 & 116 & & 216 \\
\hline Bethel................ & 398 & 282 & 366 & 1,046 \\
\hline Total................ & 2,321 & 2,304 & 3,561 & 8,189 \\
\hline
\end{tabular}

a Eleven of these are sled deer owned by white miners.

Deer belonging to the Government.

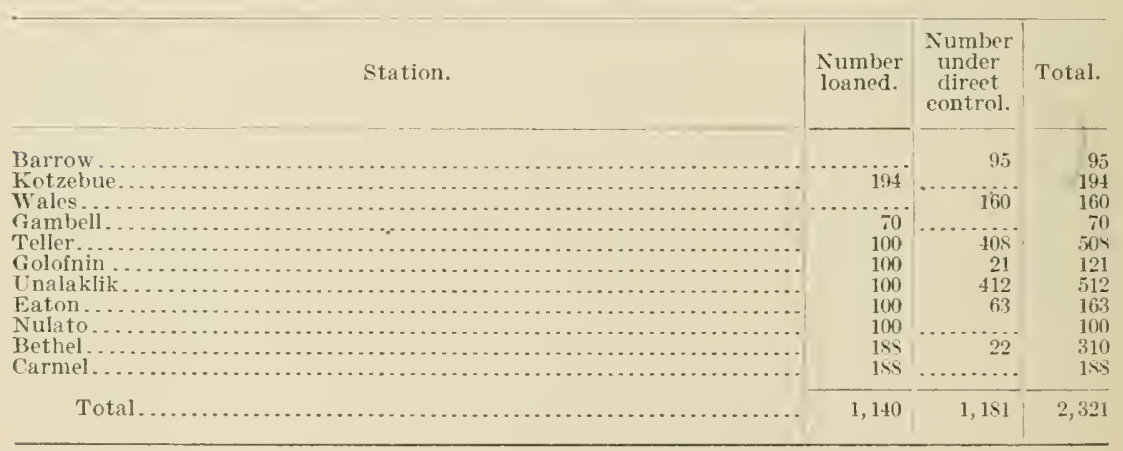


Oumership of reindeer in thish, 190\%.

Owner.

\begin{tabular}{|l|c|} 
Maults. & Fawns. \\
Male. Female. Total. Male. Female. Total. & Cirand \\
total.
\end{tabular}

POINT BARROW (ARCTIC).

Goverument

Mission.

James Brower, jr.

Ahlook (Fiskimo)

Shoudla (Eskimo).

Toktuk and Panigeo (Eskimos)

Segevan.

Panenteo.

Powrun (apprentice)

Engawishate (apprentices).

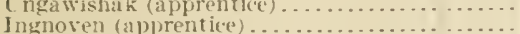

Subapprentices, 2 .

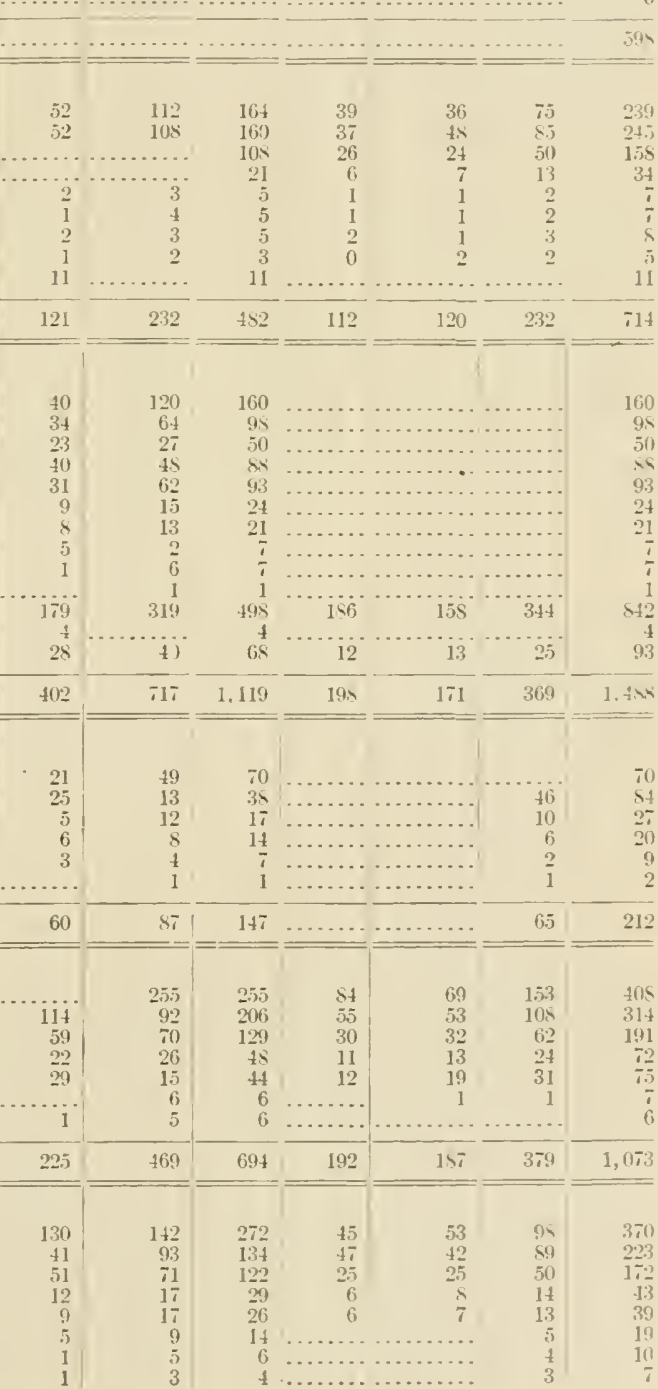

George Ootenna (Eskimo)

Thos. Sokwena (Eshimo)

Jas. Keok (Eshimo)

stanley Kiryeargruk (Eskimo)

Jos. Erungwouk (Eskimo)

Frank Jyatunguk (Eshimo)

Ohbook (Eskimo)...

Eraheruk (Eskimo)

Mlission...

Number at port Cla rence.

Number outside the pen.

Total.

GAMBELL (ST. LAWRENCE ISLAND)

Government .

Mission.

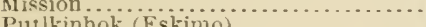

Sepillu (Eskimo)....

Penin (Eskimo).

Oonmonkok.

TELIER.

Gorernment.

Total

Albikok (Eskimo)

Dannak (Eskimo)

Sekenglook (Eskimo)

Serawlook (Eskimo)

Carrook (Eskimo).

Total.

\section{GOLOFNIN.}

Mission.

Nils Ǩlemetsen....

Traltook (Eskimo).

Constantine (Eskimo)

Taktuk (Eskimo).

Amahktoolik.

John (Eskimo) .

Alhert (Eshimo) 
Ounership of reinder in Alaska, 1904-Continued.

\begin{tabular}{|c|c|c|c|c|c|c|c|}
\hline \multirow{2}{*}{ Owner. } & \multirow[b]{2}{*}{ Male. } & \multicolumn{2}{|l|}{ Adults. } & \multicolumn{3}{|c|}{ Fawns. } & \multirow{2}{*}{$\begin{array}{l}\text { Grand } \\
\text { total. }\end{array}$} \\
\hline & & Female. & Total. & Male. & Female. & Total. & \\
\hline GOLOFNIN-continued. & & & & & & & \\
\hline Benjamin, Eskimo... & 1 & 3 & ! & & & 2 & \\
\hline Peter (Eskimo) ... & 2 & 3 & 5 & ........ & .......... & 1 & \\
\hline Mrs. Dexter (Eskim & 4 & $\begin{array}{r}3 \\
16\end{array}$ & $\begin{array}{r}7 \\
16\end{array}$ & & & $\frac{1}{5}$ & \\
\hline voserinnent & & & & & $\cdots$ & & \\
\hline Total. & 257 & 382 & 639 & 129 & 135 & 28.5 & 924 \\
\hline UNALAKLEET. & & & & & & & \\
\hline Government............. & 133 & 159 & 292 & 66 & 54 & 120 & 412 \\
\hline Ole Olsen Bahr.... & 78 & 120 & 198 & +1 & 41 & 82 & $2 \times 0$ \\
\hline Okitkon (Eskimo) & 25 & $4 \overline{7}$ & 72 & 11 & 14 & 25 & 97 \\
\hline Tatpan (Eskimo) .......... & 44 & 53 & 97 & 18 & 23 & 41 & $13 \times$ \\
\hline Stephan Ivanoff (Eskimo) .............. & 14 & 21 & 35 & 8 & 5 & 13 & 48 \\
\hline Bikongan (Eskimo) & 2 & 1 & $\begin{array}{l}3 \\
3\end{array}$ & 1 & & $\frac{1}{2}$ & 4 \\
\hline Moses Koutchok (Eskimo)................. & & & & & 2 & & \\
\hline Total ........ & 297 & 403 & 700 & 145 & 139 & 284 & 984 \\
\hline EATON. & & & & & & & \\
\hline Government............. & 29 & 26 & 55 & 4 & 4 & 8 & \\
\hline Mission....... . & 37 & 100 & 137 & 50 & 39 & 89 & 226 \\
\hline Nallogoroak (Eskino)... & 10 & 30 & 40 & 11 & 12 & 23 & 63 \\
\hline Mary Andrewuk (Eskimo)... & 117 & 140 & 257 & 55 & 46 & 101 & 358 \\
\hline Koktoak (Eskimo)............. & 11 & 19 & 30 & 9 & $T$ & 16 & 46 \\
\hline Angolook (Eskimo) & 17 & 24 & 41 & 8 & 9 & 17 & 58 \\
\hline 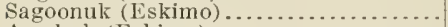 & 11 & 20 & 31 & 9 & 9 & 18 & 49 \\
\hline Accebuk (Eskimo). & j & 11 & 18 & 5 & 4 & 9 & 27 \\
\hline Arogook (Eskimo) ......... & 4 & 7 & 11 & 2 & 4 & 6 & 17 \\
\hline Amikravinik........................... & 5 & 6 & 11 & 3 & 3 & 6 & 17 \\
\hline 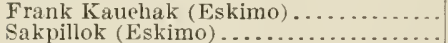 & 1 & $\frac{2}{3}$ & $\begin{array}{l}3 \\
3\end{array}$ & & $\frac{2}{1}$ & $\frac{2}{2}$ & $\begin{array}{l}5 \\
5\end{array}$ \\
\hline & & & & & & & \\
\hline Total....... & 249 & 388 & $63 \overline{7}$ & 157 & 140 & 297 & 934 \\
\hline NULATO (YUKON VALLEY). & & & & & & & \\
\hline Mission..................... & 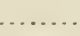 & .......... & 150 & & & 66 & 216 \\
\hline BETIFL (KUSKOKWIM). & & & & & & & \\
\hline Government................ & & 22 & 22 & & & & \\
\hline $\begin{array}{l}\text { Mission } \\
\text { Waseby (Eskimo) }\end{array}$ & 135 & 182 & $\begin{array}{r}323 \\
9\end{array}$ & 64 & 71 & 135 & 458 \\
\hline $\begin{array}{l}\text { Waseby }(\text { Eshimo }) \\
\text { Robert }(\text { Eshimo } \ldots \ldots \ldots\end{array}$ & $\begin{array}{l}4 \\
4\end{array}$ & $\frac{5}{7}$ & $\begin{array}{r}9 \\
11\end{array}$ & $\begin{array}{l}5 \\
2\end{array}$ & $\begin{array}{l}1 \\
3\end{array}$ & $\vdots$ & $\begin{array}{l}15 \\
16\end{array}$ \\
\hline Tommy $($ Eskimo $) . \ldots \ldots \ldots \ldots \ldots \ldots$ & 1 & 2 & 3 & & 2 & 2 & \\
\hline Henry (Eskimo)....................... & 1 & 2 & 3 & & 2 & 2 & 5 \\
\hline Sara (Lapp) ........ & 68 & 124 & 192 & 47 & 44 & 91 & 283 \\
\hline 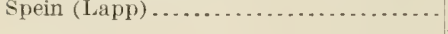 & 67 & 109 & 176 & & 32 & 66 & 242 \\
\hline Total....... & 280 & 459 & 739 & 152 & 155 & $30 \pi$ & $1 ; 046$ \\
\hline Grand total......... & 1,891 & 3,137 & 5,307 & 1,085 & 1,047 & 2,284 & 8,189 \\
\hline
\end{tabular}

\section{PERSONNEL.}

[nited States general agent education in Alaska: Sheldon Jackson. Assistant agent: William Hamilton.

General superintendents: Central division, Carl O. Lind, M. D., Unalakleet, Alaska; northwestern division, William T. Lopp, Males, Alaska.

Local superintendents: Samuel R. Spriggs, Point Barrow: Dana H. Thomas, Kotzebue; IV. T. Lopp, Wales; Ludvig Larson, Teller; Edgar O. Campbell, M. D., Gambell (St. Lawrence Island); O. P. Anderson, Golofnin: C. O. Lind, M. D., Unalakleet (Eaton); Adolf Stecker, Kuskokwim; Julius Jette, Nulato; G. S. Clevenger, H. E. 
Redmrer, Copper Center; J. H. Kilbuck, Wainwriglt: D. W. Cram, Bettles.

Special agent: J. H. Jasberer, Hancock, Mich.

Lap and Finn teachers: Allred Salmonsen Nilima, Kotzebue; Per Nilsen Bals, Nulato; Nils Klemetsen, Isak Andreson Bango, Teller; Albert Lahti, Sigfried Sotka, Gambell; Anders Johmson, Trnalakleet; Nils Sara and Per Spein, Bethel, Ktuskokwim Valler; John Wuori, Louis Karbum, Erick Lampela, and Peter Ilatta, Copper Centel' Adoll Sari, Ml. Jensen, C. Raisanen, Bettles.

Eshimo herders and apprentices.-Point Barrow: Ahlook, Shoudla, Brower, jr., Tokpuk, Panigeo, Segeran, Paneoneo, Powun, Lngawishok, Ingnoren. Ḱotzchue: Electoona. Otpelle. Ohamon, Oglivalek, Minungon, Munuok. Cape Prince of Wales: George Ootenna, Thomas Sokwena, James Keok, Stanley Kivrearzink, Joseph Erungwouk, Frank Iyatunguk, Peter Ibiono, Okboak, Eraheruk. Gambell (St. Lawrence Island): Putlkinhok, Sepilla. Pinink, Oommookok. Teller: Allikok, Dumnak, Sekeoglook, Serawlook, Coxrook. Golofnin Bay: Tautook, Constantine, Taktuk, Ahmahkcloolik, John, Albert, Benjamin, Peter, Mrs. Dexter. Unalakleet herd: Okitkon, Tatpan, Stephan Tranofl, Bikongan, Moses Koutchok. Eaton herd: Naliogoroak, Mary Andrewuk, Kotoak, Angolook, Sagoonuk, Acrebuk, Aragook, Amikravinik, Frank Kauchak, Sakpillok. Nulato: Stephen Annu, Alexander Kulana, John Rorondelel. Kuskokwim: Wasili, Robert, Tommy, and Henry.

STATIONS.

Kotzebue.-The past season at this station has been a most prosperous one. There was very little extremely cold weather and the snowfall was light. As a result a very small percentage of this year's fawns was lost. In midwinter Doctor Lind inspected the herd and reported it in the best possible condition. Early in October. 1903, a river steamer was caught in the ice near the mouth of the Kowak River with a number of people on board. Thus opportunity was given to the station to sell some surplus male deer and relieve the destitution of those on board. Many of the deer bought were used for transporting the owner and his property to the nearest camp. One man, after hauling $\$ 00$ pounds of supplies over 200 miles, disposed of his deer at a profit of $\$ 35$. The use of deer as sled and pack animals is growing in faror among the miners in this section.

Thales.-The winter of 1903-4 was a favorable one for the deer. From September to December the temperature was not above freezing nor below zero, and during the rest of the winter the weather never. got warm enough to melt the snow, though the coldest was only $25^{\circ}$ below zero. The result was that there was no ice on thecmoss and so the deer could obtain their food easily. A goutragt had been 
made to sell 168 female deer to the Government and deliver them at the Teller reindecr station sometime during the winter. Considerable difficulty was experienced in attempting to separate the deer to be sold from the rest of the herd. Finally it was deemed advisable to drive the entire herd to Teller where there were better facilities for dividing it. The trip was made in safety and the deer delivered in good condition.

Gambell (St. Laurence Island).--The winter was an unusually mild one and the herd did well until the spring, which the Laps report was a hard one for lawning. The grazing ground of the herd has been changed owing to the fact that they have been feeding too long on the same range, and also on account of the increase in the size of the herd. The new range is about 35 miles from the station in the center of a fine moss pasture entirely unused. Several deer have been damaged during the year by loose dogs. However, in each case the owners of the dogs were compelled to make restitution. Mr. Thomas Richards proved himself to be a most able assistant to Doctor Campbell at this difficult and dangerous station.

Teller.- The mission obtained the contract to earry the mail from Teller to Marys Igloo and from Teller to Cape Prince of Wales. The round trip to each place is about 140 miles. Serawlook, an apprentice, made 14 trips to Marys Igloo and 10 to the Cape, covering about 3,300 miles from November 1 to June 1 with reindeer. The majority of white people in the neighborhood ridiculed the idea that reindeer could bring the mail through on time and compete with dogs. It was also considered very unwise by them that a native should drive the mail. However, results were a surprise even to those who believed in the deer. Serawlook always made good time and on many trips exceeded the best time made by crack dog teams under most farorable conditions. One round trip was made in twentyseven hours, three hours faster than the best dog teams had ever made it.

Golofnin.-Mr. Anderson reports that the year has been a rery successful one. The number of deaths in the herd from disease or accident has been very small. Several were sold for the meat markets at Nome and Council City. A contract for freighting goods was suecessfully filled, which is expected to open a new field of usefulness for the deer in the future. The most trouble met with at Golofnin has been due to the carelessness of miners who leave their camps without taking sufficient eaution to completely extinguish their fires. The moss on which the reindeer feeds, being dry as tinder, burns very rapidly, and unless the fire is checked at once considerable pasturage may be destroyed.

Eaton (Unalakleet post-office).-During the year a permanent division of the herd was effected, Messis. Bals, sr., and Ole O. Bahr 
each having charge of one dirision. To separate the herd it was found advisable to build three corrals: thereby the work was done in less time and with much more accuracy. During the year Doctor Lind nuade an extensive tour of inspection of most of the herds. The round trip from Inalakleet to Bethel, Kuskokwim, lasted from Norember 9 to December 23. The deer finished the trip in excellent condition, only one being lost. During the winter an opportunity was unexpectedly presented to demonstrate in a more special way the utility of the reincleer to the white population of Alaska. A contract was taken to haul 7 tons of freight from the Fish River to the Innuchuk country, over 100 miles distant. The freight was carried safely to its destination in spite of a heary storm which was raging at the time. Some men traveling with dogs arrived thirty-five hours later, thus proving conclusively the superiority of deer over dogs.

The Unalakleet herds did rery well during the rear. The deer have had good pasture and were seldom prevented from getting at the moss by an icy erust forming over the snow. Although the two herds were never less than 20 miles apart, the herders had considerable difficulty in keeping the deer from strolling from one herd to the other. During the fawning season the weather was most beautiful and the death rate among the fawns in both herds exceptionally low.

The health among the herders lias been excellent. All the apprentices have done very well in their work and are highly thought of by the chief herders. At Unalakleet there are at present not less than 30 Eskimos who live wholly by the deer industry, and fully half that number are indirectly benefited by their relatives having deer.

Bethel, Kusholuim Valley.--It will be remembered that on February 5, 1903, two herds of reindeer in charge of Nils P. Sara and Per M. Spein were sent from Lnalakleet to strengthen the herds in the Kuskokwim Valley, and that owing to a combination of circumstances Messrs. Sara and Spein with their reindeer were detained with their herds for ten months in the neighborhood of Andreafski on the Yukon River.

Norember 7,1903 , Dr. C. O. Lind, accompanied by Nils Bals, a Lapp, and Nallogoroak, an Eskimo, left Unalakleet with reindeer teams for the herds at Andreafski, reaching the reindeer camp of Messr's. Sara and Spein on the 23d.

On November 26 a start was made with the families and herds of Sara and Spein for the Kuskokwim Valley (southwest Alaska), which was finally reached December 3.

Messrs. Sara and Spein were at once given charge of all the herds in the Kuskokwim Talley, taking the places of Messrs. N. P. and P. N. Bals, who had left the Fuskokwim for Lnalakleet.

S. Doc. $61,53-3-3$ 
Upon the return of Dr. C. O. Lind to Unalaklect, December 22, Mr. Nils Persen Bals was placed in charge of herd No. 2, at Unalaklik, on Norton Sound, and his son, Per Nilson Bals, was given charge of the Roman Catholic herd at Nulato, Lower Yukon River.

THE CRUISE OF DR. WILLIAM HAMILTON, ASSISTANT AGENT.

The annual visit of inspection of United States public schools in western Alaska and the tour of the Yukon River with a view of ascertaining the points at which it would be advisable to establish public schools was made by Dr. William Hamilton, the assistant agent. The following is an abstract of his itinerary:

Leaving Washington June 8, Dr. Hamilton joined the U. S. S. Thetis at Honolulu for the arctic cruise. From Honolulu the Thetis proceeded direct to Unalaska, where she arrived July 14. While the Thetis was coaling and making repairs to her machinery, Doctor Hamilton inspected the public school at Unalaska, conferring with the teachers and mombers of the local school committee and authorizing needed repairs to the school building.

On July 25 and 27 the seal islands St. George and St. Paul were visited. The schools on these islands, by the terms of their contract, are under the control of the North American Commercial Company, the lessee of the islands.

On July 30 the school and reindeer station on St. Lawrence Island were inspected, and Doctor Camphell and Mrs.Campbell, the teachers, were received on the Thetis for passage to the mainland, where, after three years of continuous residence on the island, they were to enjoy a well-earned vacation.

At Nome, July 31, the Thetis took on board mail matter for the remote schools on the shores of Bering Sea and the Arctic Ocean, and then procceded to St. Michael, near the mouth of the Yukon, where Doctor Hamilton left the vessel.

At St. Michael Doctor Hamilton made arrangements for the storing of the lumber for the new schoolhouse until the arrival of the carpenter who was to erect the building, increased the membership of the local school committee, and completed the arrangements for the opening of the new term of school in September.

On August 7 he left St. Michael on the steamer Rock Island for the long journey up the Yukon River. Among the passengers were Mr. H. E. Redmyer and his assistant, who were to have charge of the transportation of a herd of reindeer from Bethel to Copper Center, and many consultations were had regarding this important undertaking.

At Ikogmut (Russian mission) Mr. Redmyer's party left the steamer to commence the overland part of their journey. A United States public school was opened at Ikogmut October, 1904. 
Koserefsky (Iloly Cross Mission) was risited on August 10, and interviews were had with the teachers in charge of the school at that place.

The Episcopal mission at Anvik was risited on August 11, and a consultation had regarding the opening of a public school at this place.

A short stop was made at Nulato during the morning of August 13. $A$ teacher for the coming term was appointed and statistics obtained regarding the reindeer herd at this place.

On August 15 the Rock Island left the Yukon and entered the Tanana River, continuing its voyage to the towns of Chena and Tanana, on its upper waters. Young as these two towns are, they have already become incorporated and manage their own schools and other local affairs.

Returning to the mouth of the Tanana River, Doctor Hamilton left the Rock Island, which continued her royage down the river to St. Michael, and awaited the arrival of the steamer Sarah, en route to Dawson. During this stay he visited the neighboring Episcopal mission of St. James. It is the intention of the Bureau of Education to extend aid to the school in connection with this mission.

In the village of Tanana Doctor Hamilton found an experienced teacher, who was subsequently placed in charge of a new school at Rampart.

On September 1 the steamer Sarah arrived at Tanana, and Doctor Hamilton went on board for passage to Dawson. During the afternoon of September 2 the Sarah arrived at Rampart. Miss Parke, the teacher, at once went ashore, and with the assistance of a newly organized local school committee, arrangements were entered into for the opening of school.

Historic Fort Yukon was reached on the morning of September 4 . The teacher appointed by the Bureau of Education to open the school at this place had not yet arrived.

After cautiousty and successfully passing through the troublesome region known as the Yukon Flats, the Sarah tied up at Circle City wharf on September j. This once prosperous metropolis of the Yukon Valley is now almost deserted, as the result of a stampede to the Fairbanks mining district. However, there are many native children in the vicinity of the town, and it is proposed to reopen a public school at Circle City in the near future.

Near the mouth of Miller Creek is the town of Eagle, the last of the settlements on the American side of the international boundary line between Alaska and British Columbia. This important point, the location of the United States custom-house and army post. Fort Egbert, is incorporated and manages its own school affairs. Beyond the limits of the incorporation is a native village and it is the intention 
to organize a school for the benefit of the children in this settlement. From this point it is hoped to reach with school privileges the Ketchumstocks, a tribe inhabiting the interior country near the sources of Copper River.

A short distance above Eagle the steamer passed beyond the one hundred and forty-first meridian and entered British Columbia.

At Dawson Doctor Hamilton remained two days, during which time he spent many hours in the public schools of Dawson, becoming acquainted with the principal and teachers, and observed the methods used.

Leaving Dawson on the steamer Selkirt: September 9, he arrived at White Horse at the foot of White Horse Rapids, the limit of river travel and the northern terminus of the White Pass and Yukon Railway. From this place Doctor Hamilton reached Skagway over the White Pass and Yukon Railway on September 14.

From Skagway he proceeded to Sitka, where he repeatedly risited the three public schools and consulted with the members of the local school committee.

He left Sitka on September 29, and arrived at Seattle October 4.

Having completed his business with the firms in Seattle and San Francisco who had furnished the season's supplies for the work in Arctic Alaska, Doctor Hamilton left San Francisco on Octoher 12, arriving at Washington five days later, completing a tour of inspection which had covered about 14,500 miles.

\section{COOPERATION OF TIE TREASURY DEPARTMENT.}

I take this opportunity to express my thanks for the cooperation of the honorable the Secretary of the Treasury and of Capt. Charles F. Shoemaker, Chief of the Revenue-Cutter Scrvice, in granting transportation on the revenue cutters to the assistant agent of education and to teachers for remote points on the shores of Bering Sea, inaccessible by commercial vessels.

The cordial assistance rendered by Capt. Oscar C. Hamlet, commanding L. S. S. Thetis, and the numerous courtesies extended by him and by the officers attached to that vessel to persons in the employment of the Bureau of Education were especially appreriated.

All of which, with accompanying papers, maps, and illustrations, is respectfully submitted.

SHELDON JACKSON,

General Agent of Education in Alastia.

The Commissioner of Education. 


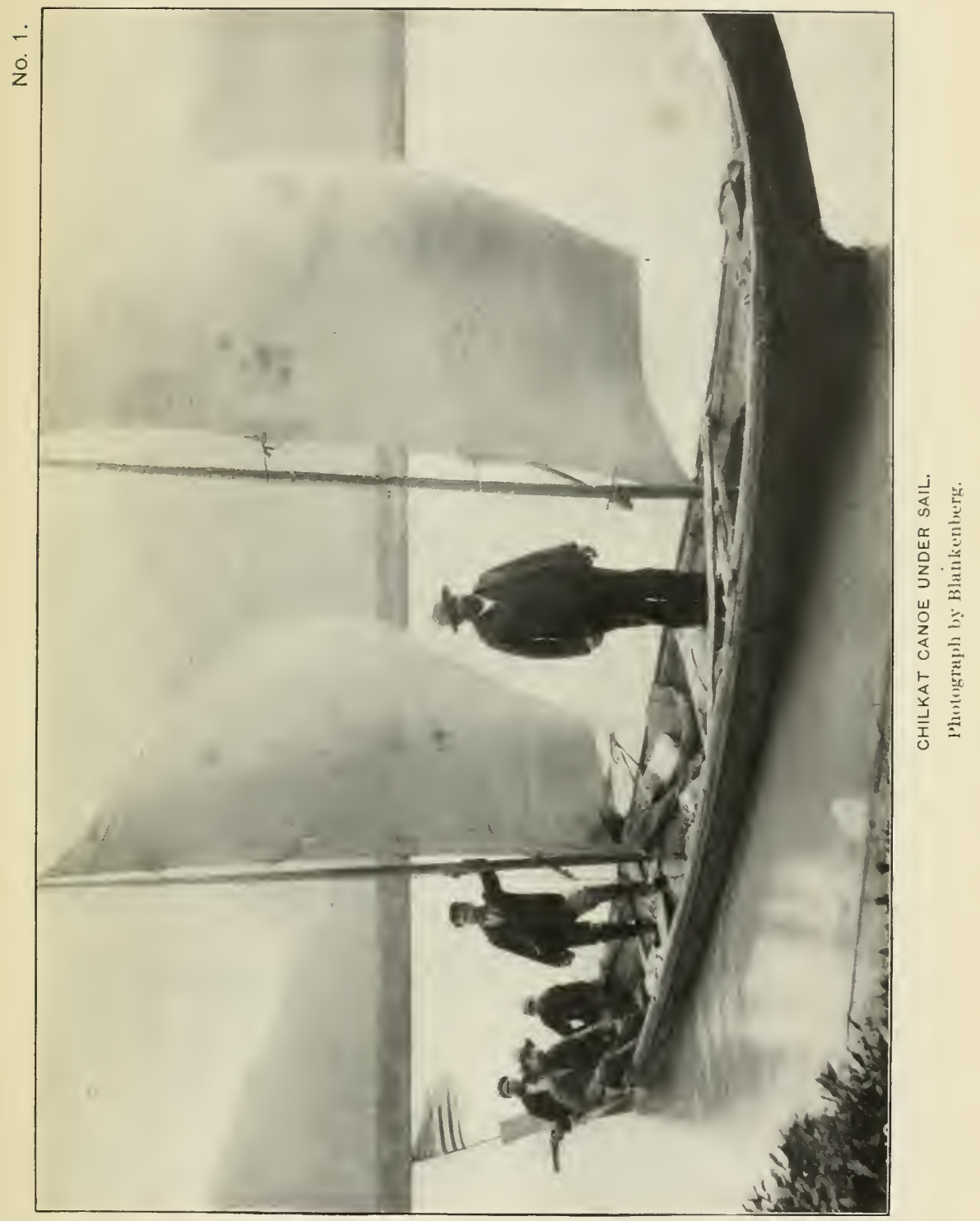



No. 2.

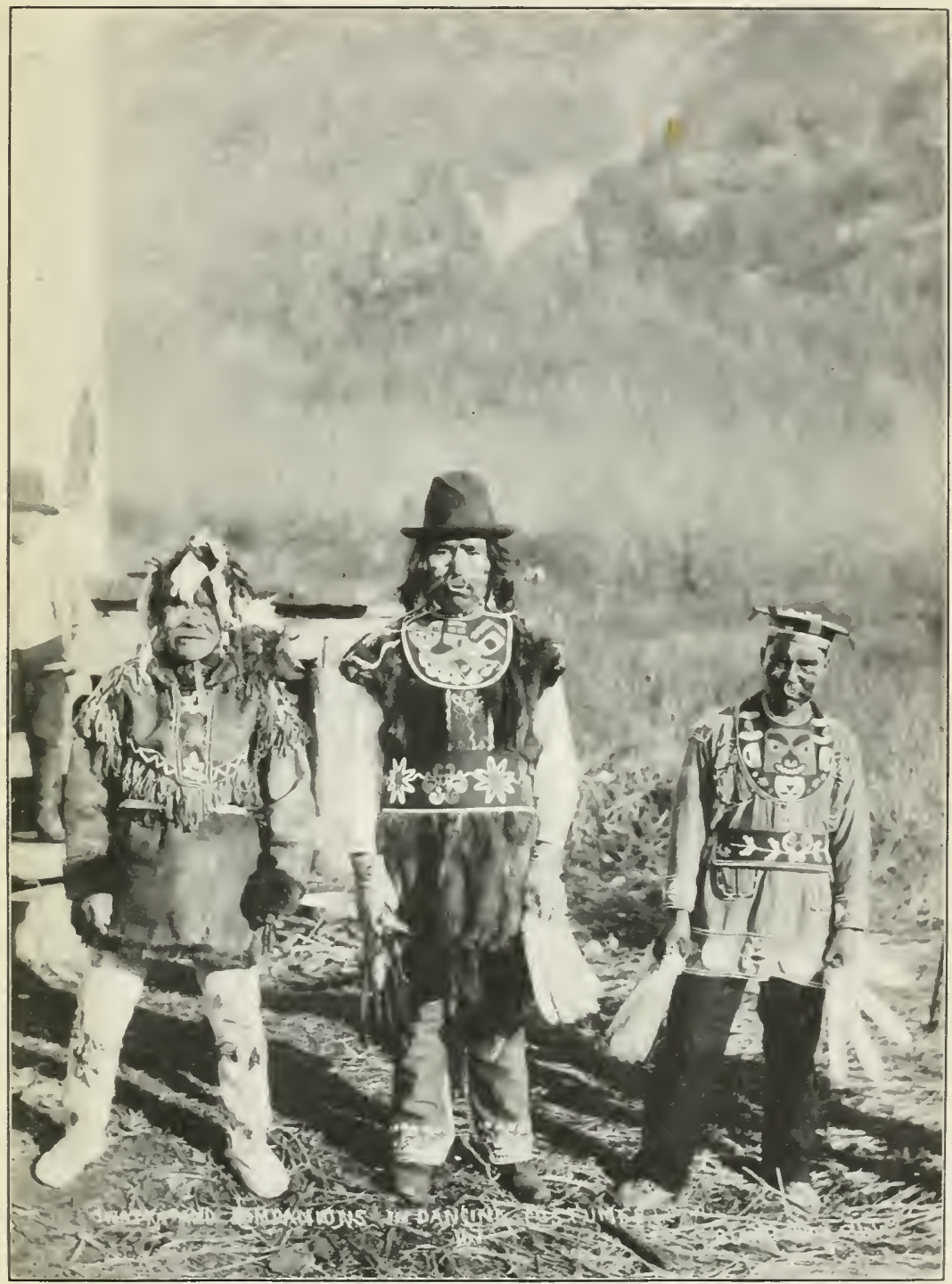

CHILKAT DANCING PARTY.

Photesraph bx Blankenberg. 

No. 3.

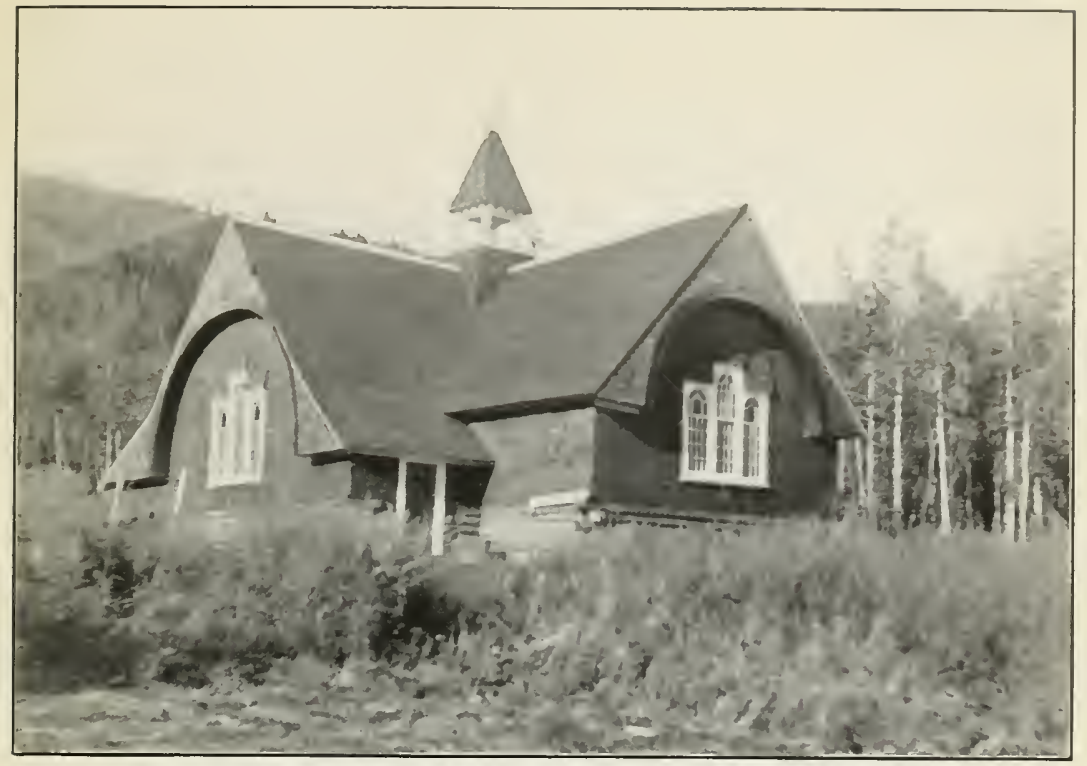

EPISCOPAL CHURCH, ST. JAMES MISSION, YUKON RIVER.

No. 4.

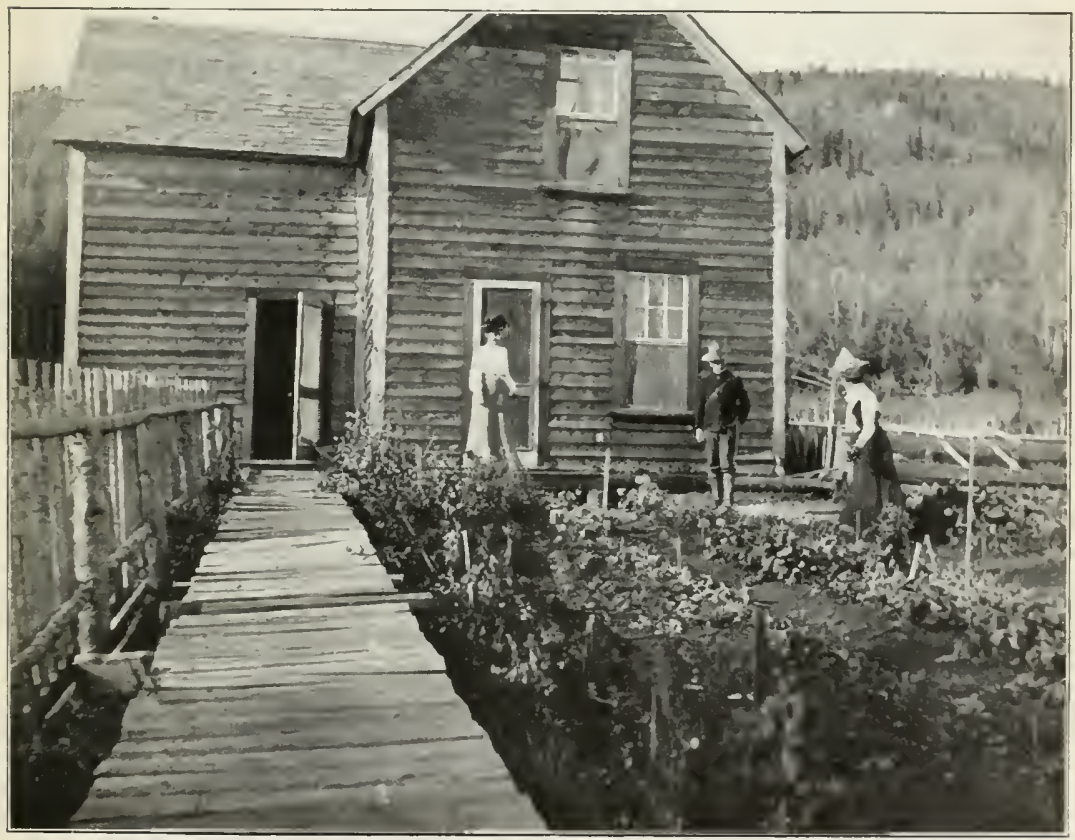

EPISCOPAL HOME, ST. JAMES MISSION, YUKON RIVER.

l'hotographe by Wm. Hamilton, l'h. W. 



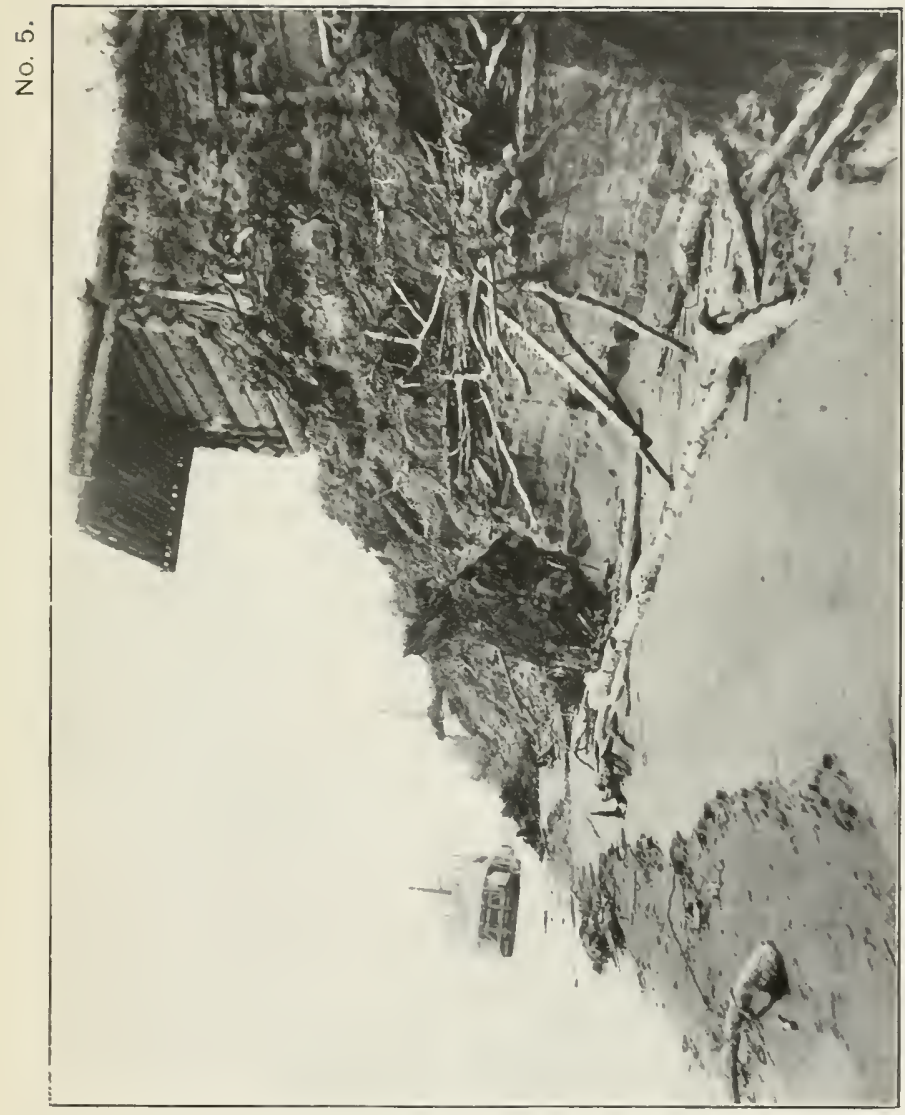





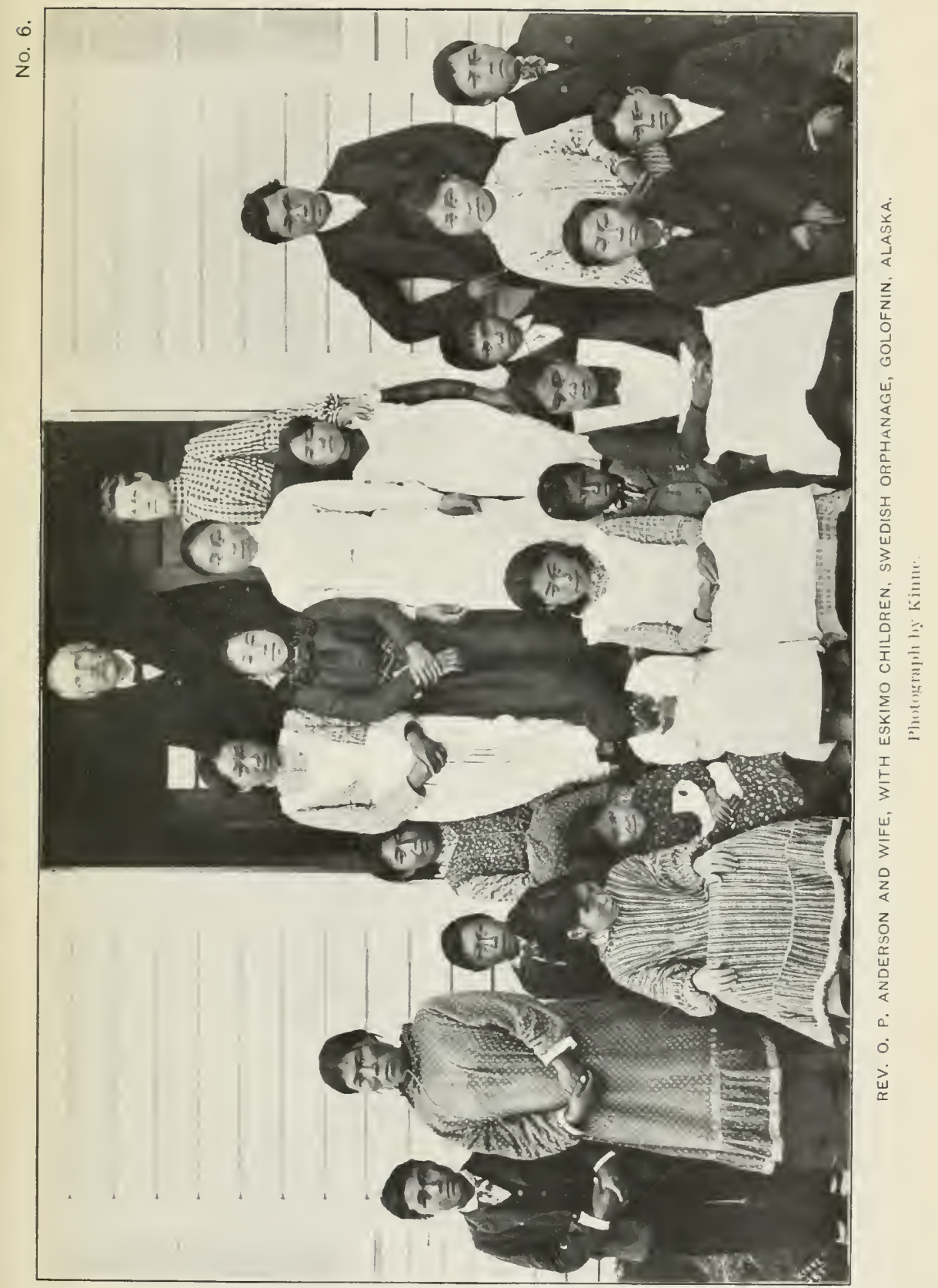





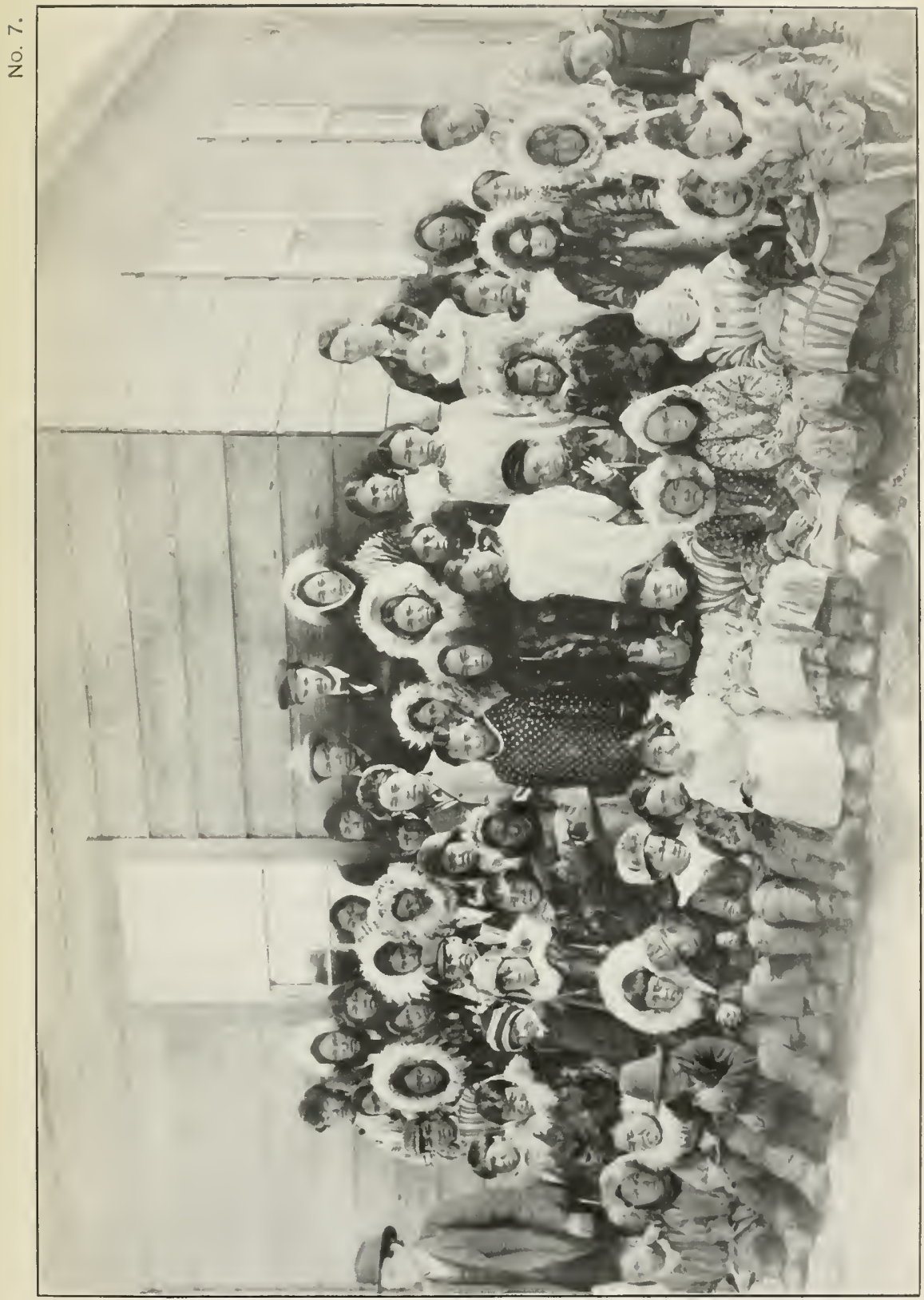





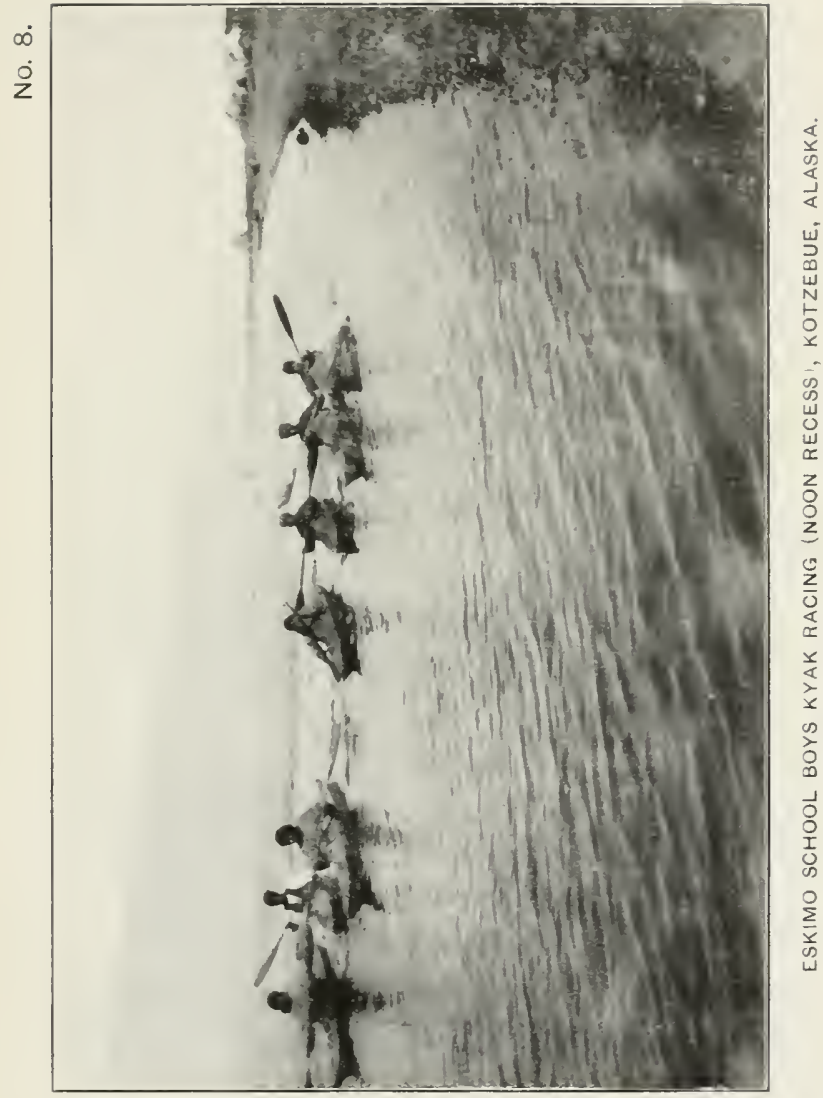





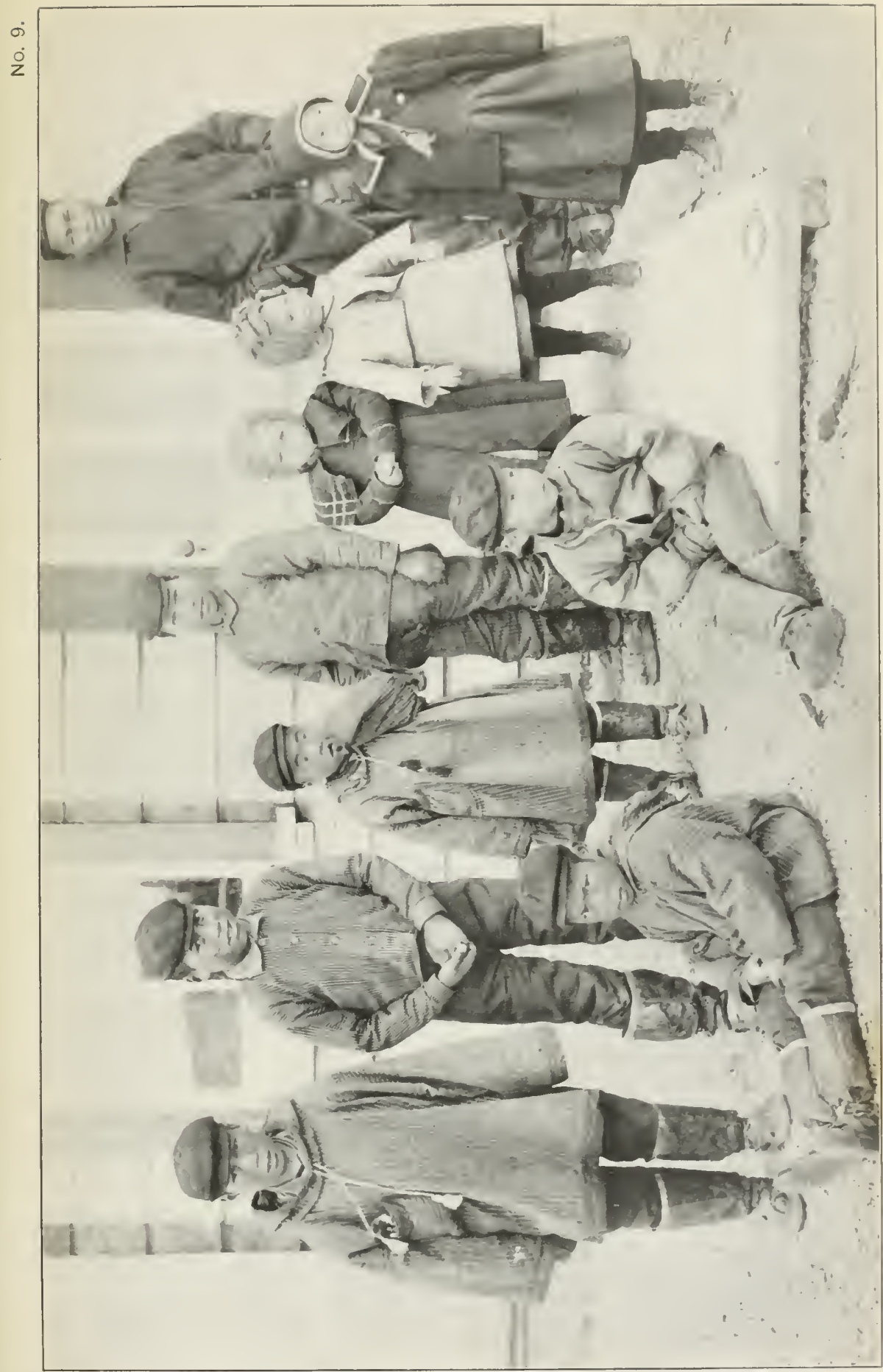





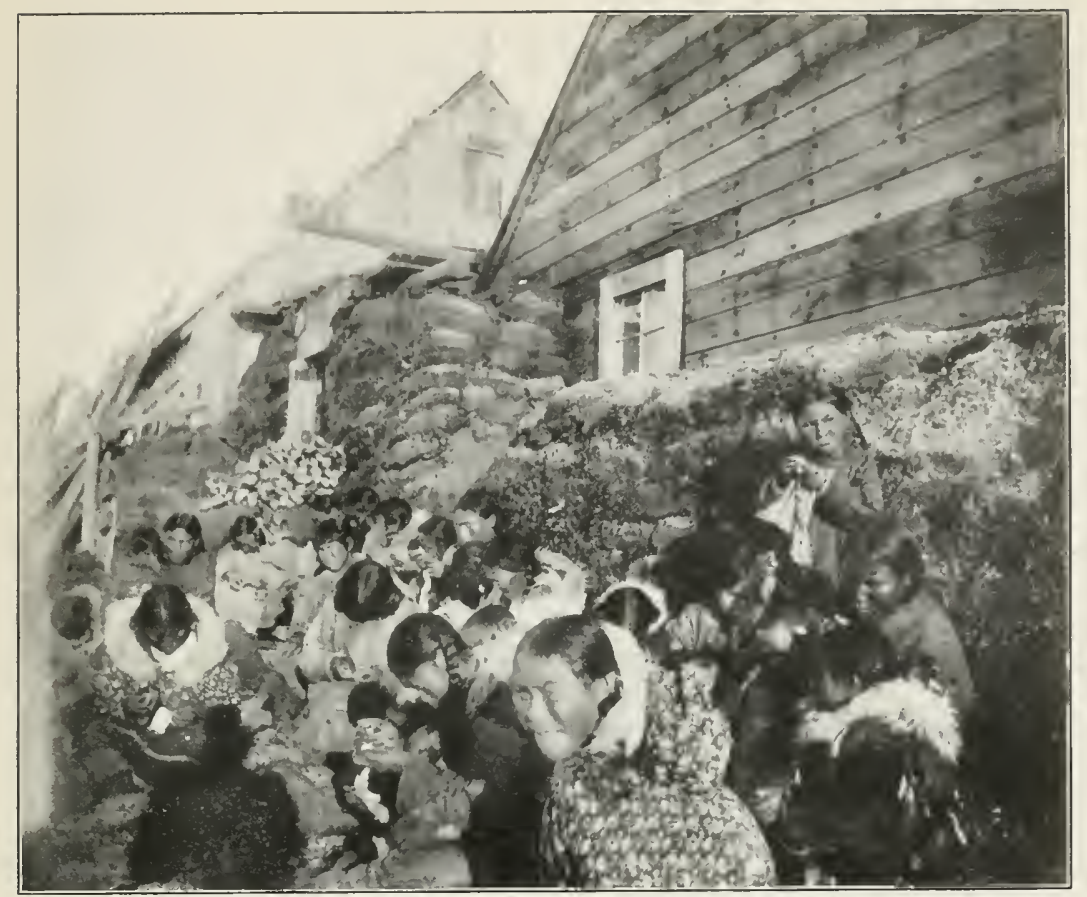

ESKIMO OUTDOOR-SEWING CLASS, FRIENDS' MISSION, KOTZEBUE, ARCTIC OCEAN.

No. 11.

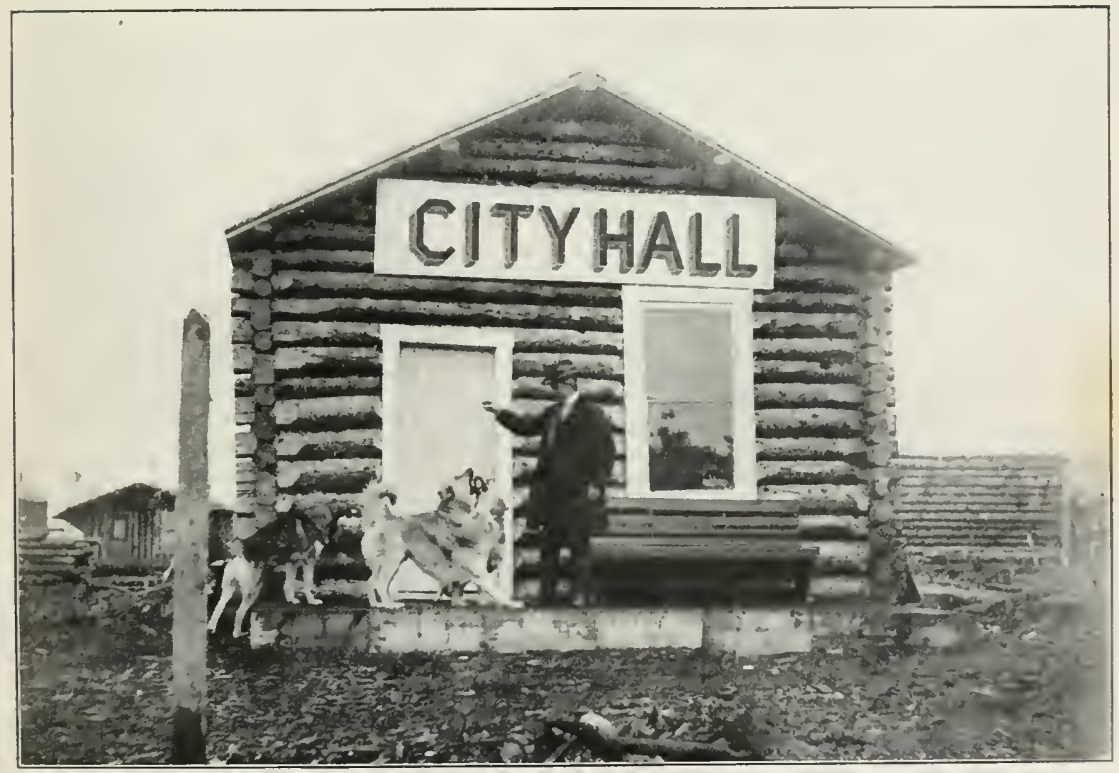

CITY HALL, FAIRBANKS, ALASKA, 1904. 



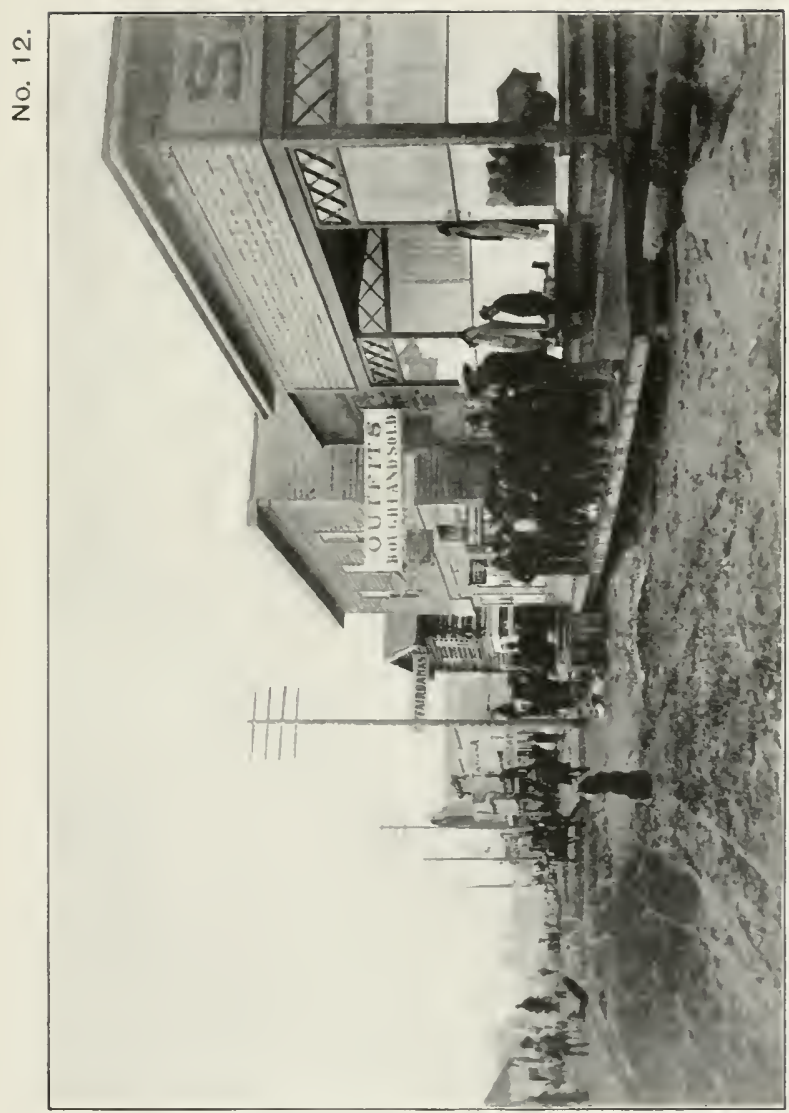

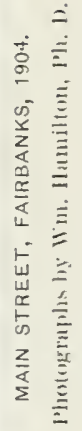





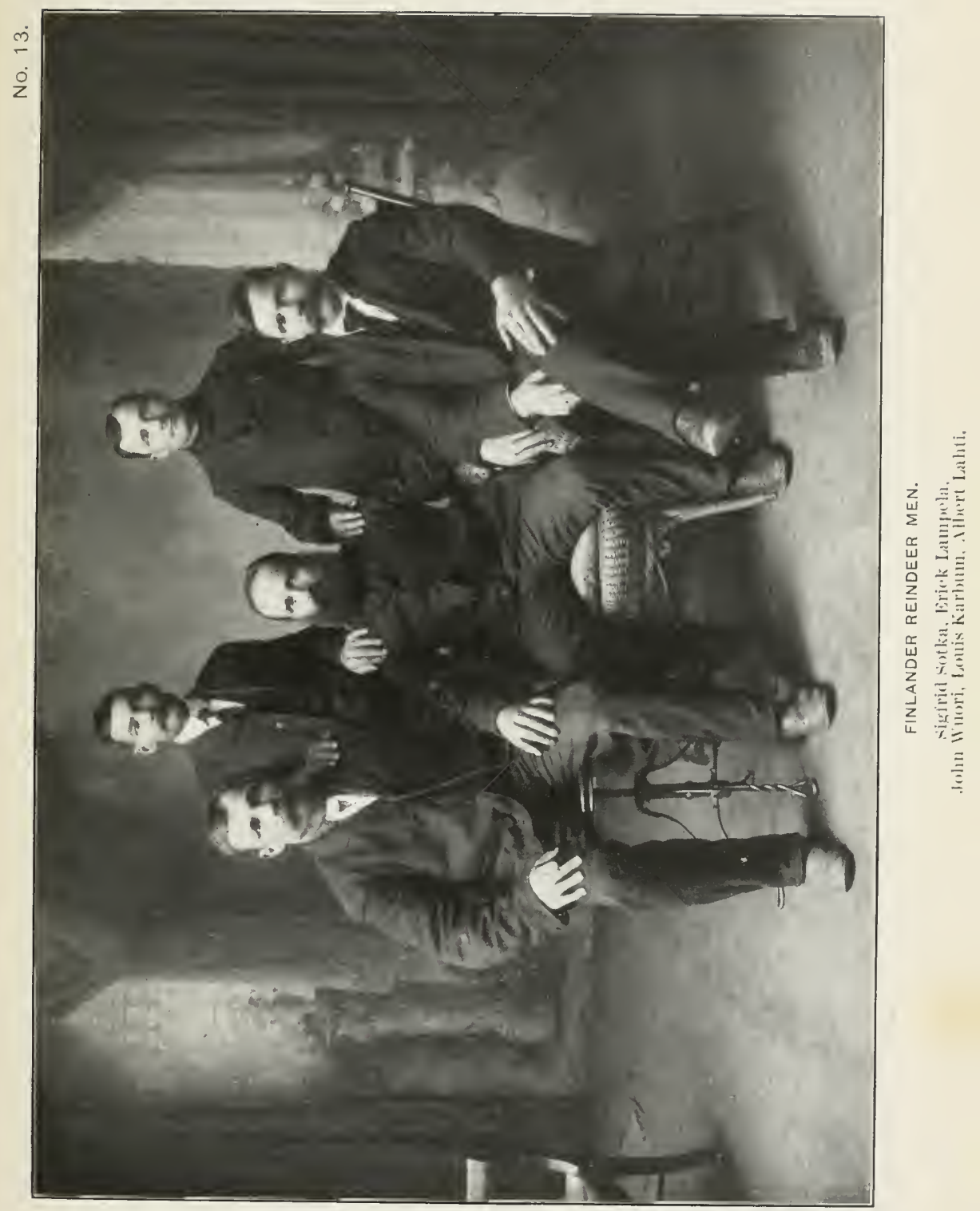


No. 14.

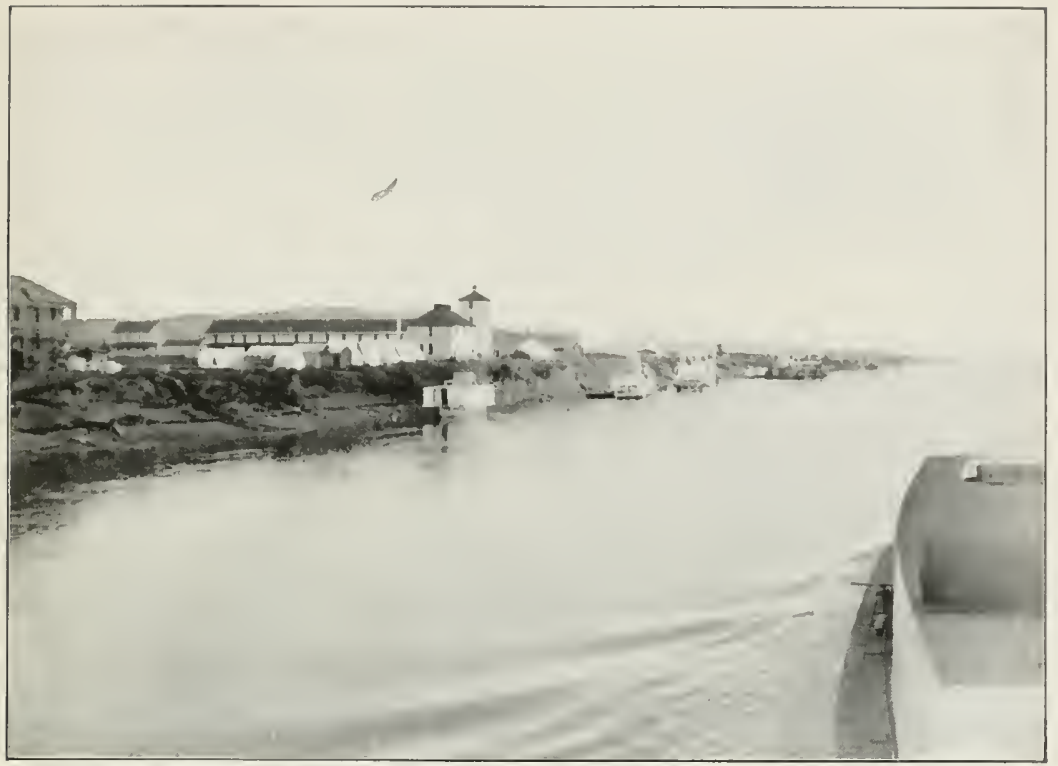

FORT GIBBON, YUKON RIVER.

No. 15.

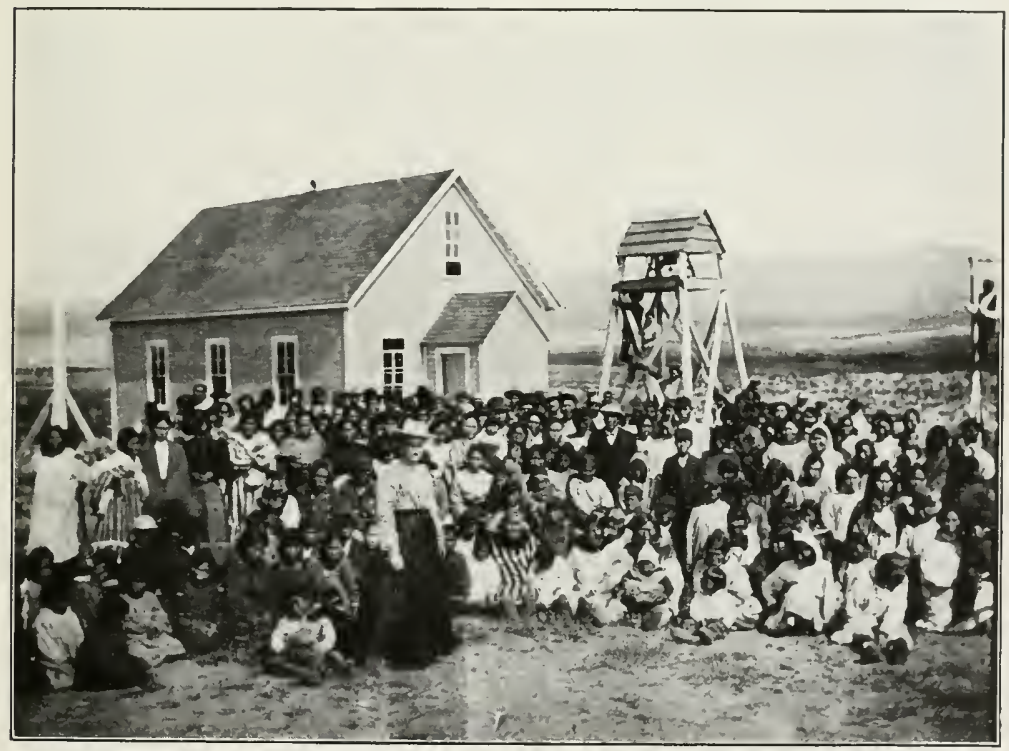

ESKIMO CHURCH AND CONGREGATION. SWEDISH EVANGELICAL MISSION, GOLOFNIN. Photouraph by kinue. 



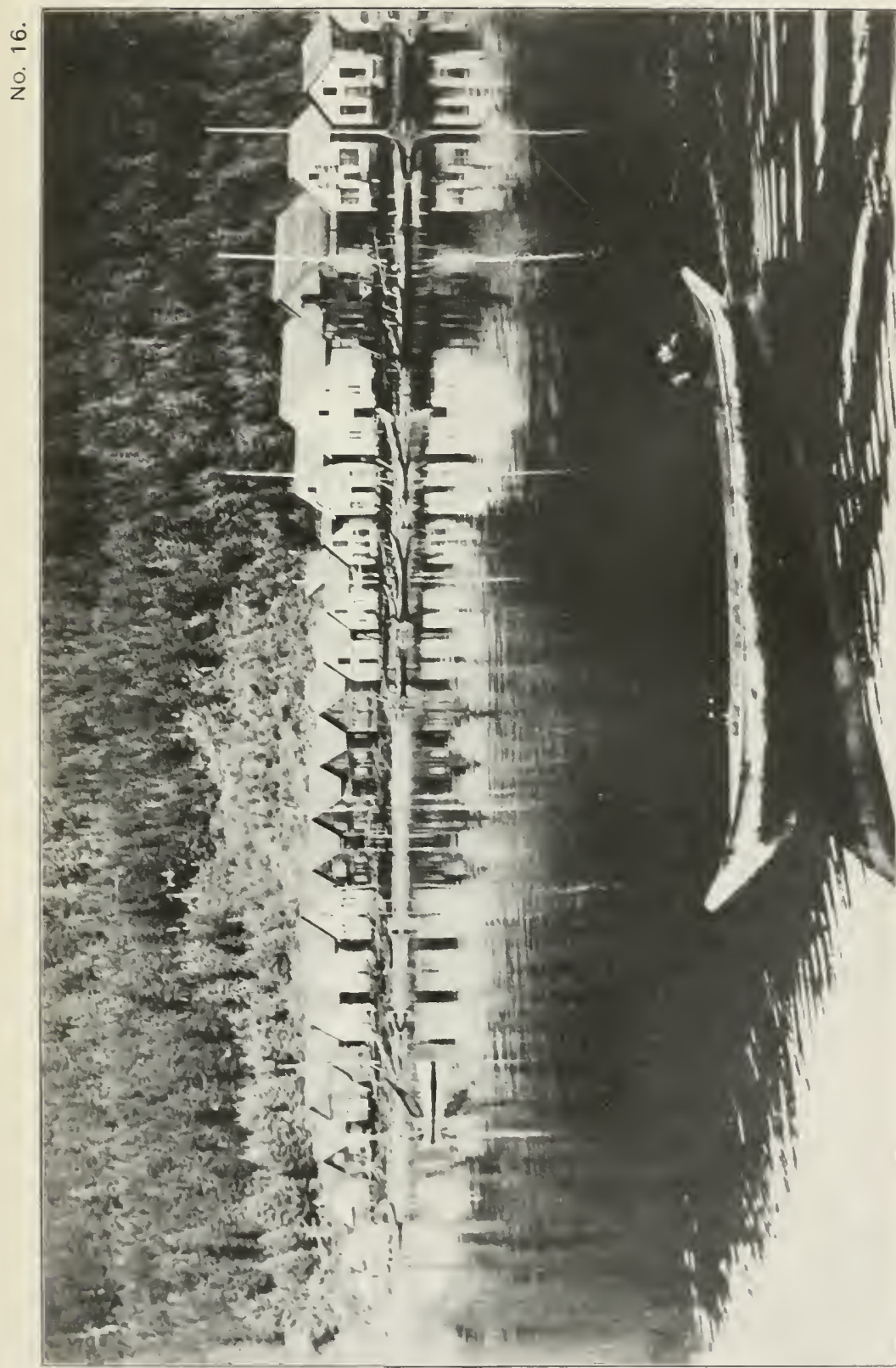





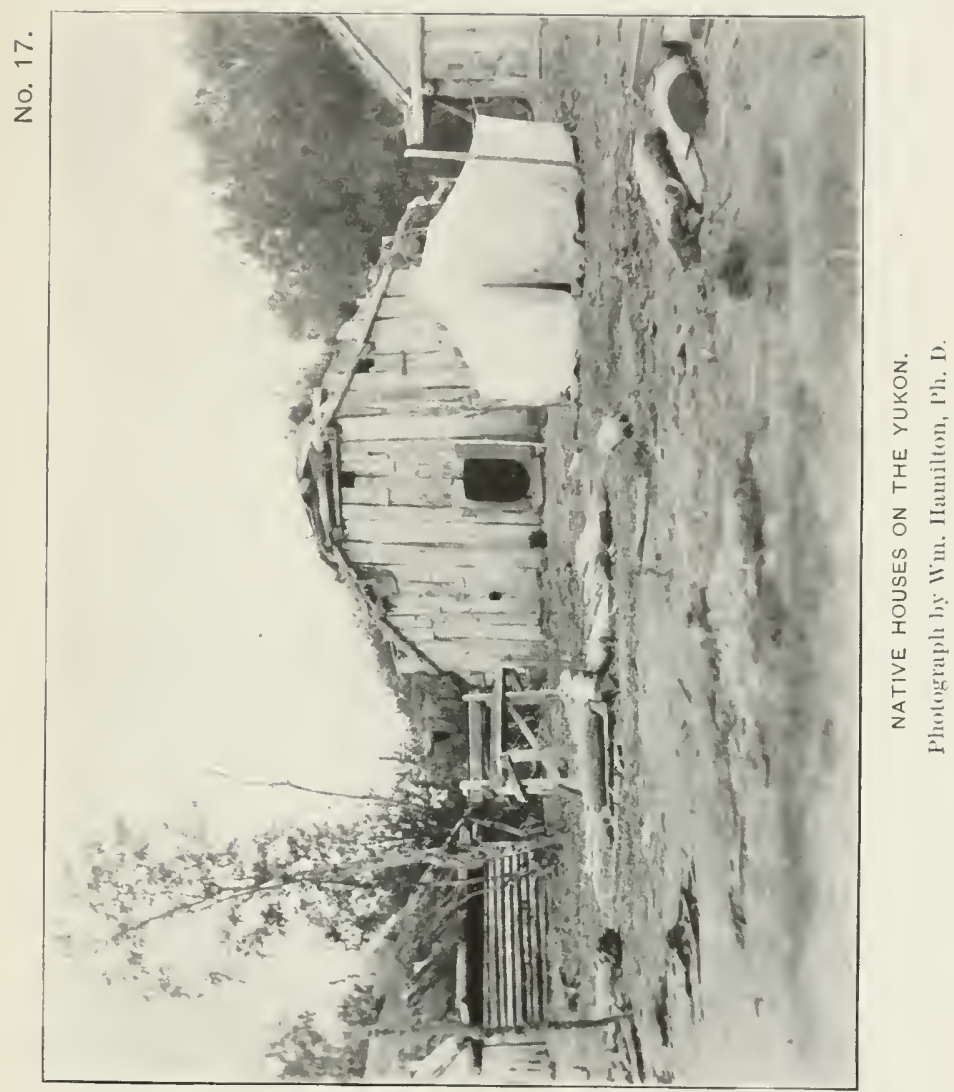





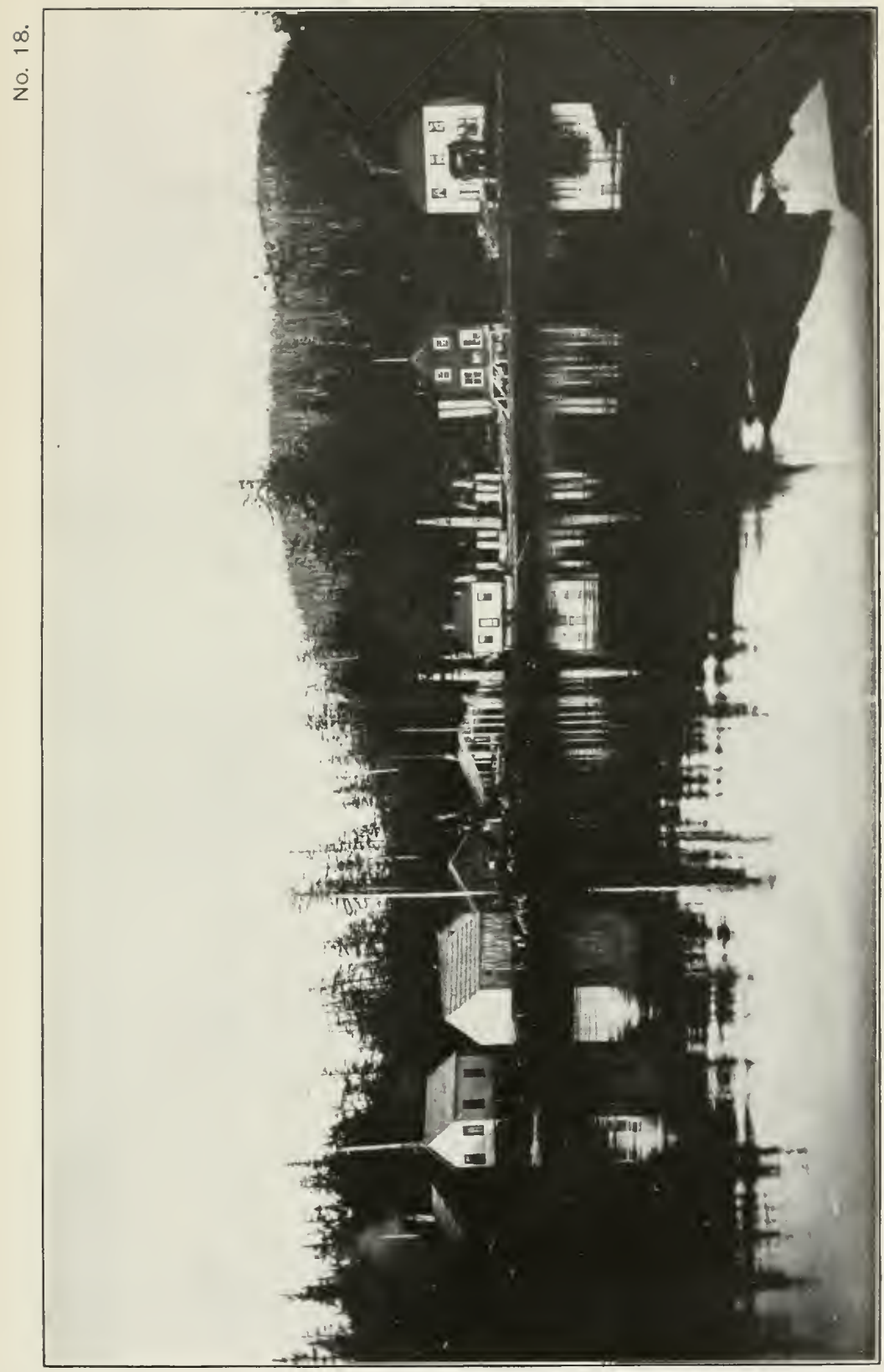

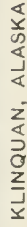


$\frac{\dot{0}}{\dot{0}}$

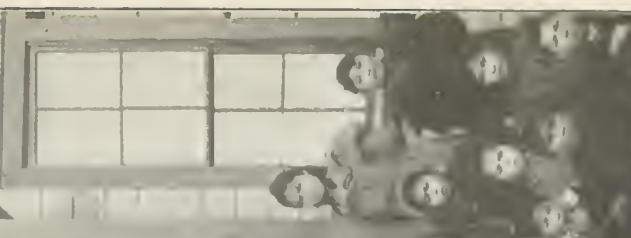

$x^{2}:$

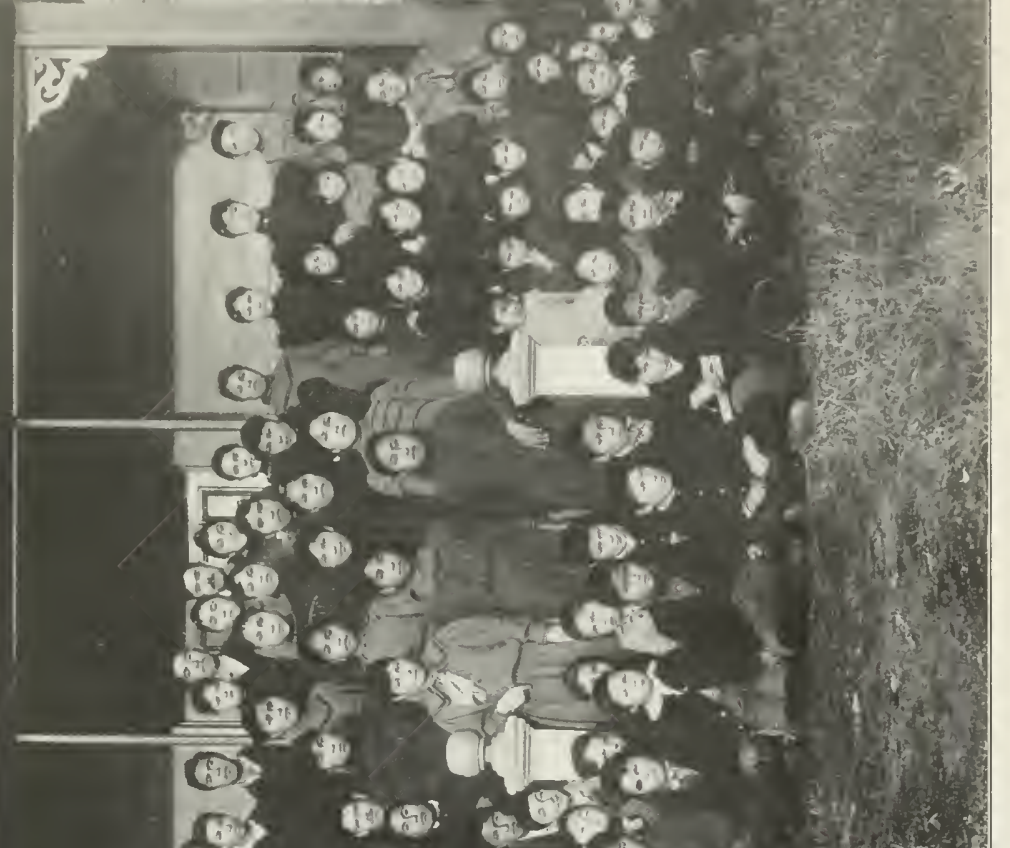

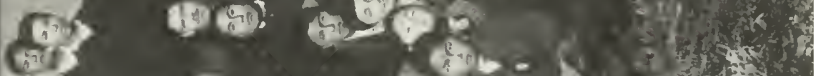

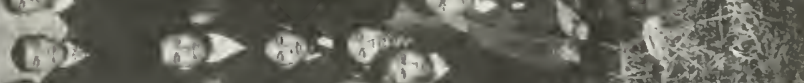

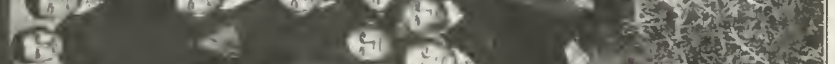
Bifes Gitar

32. $5(6)\}$

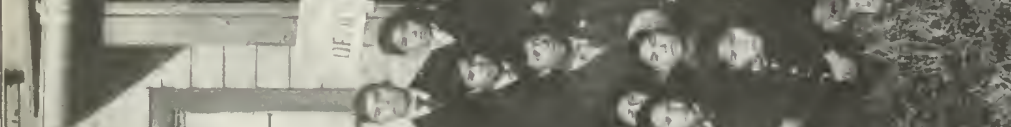

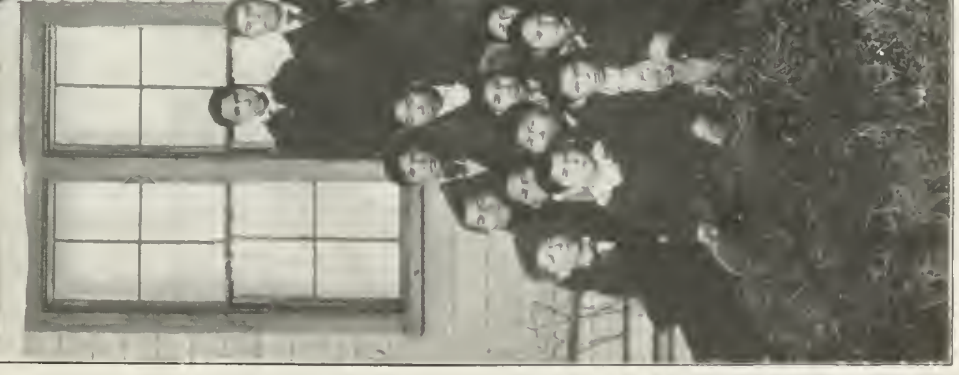



No. 20

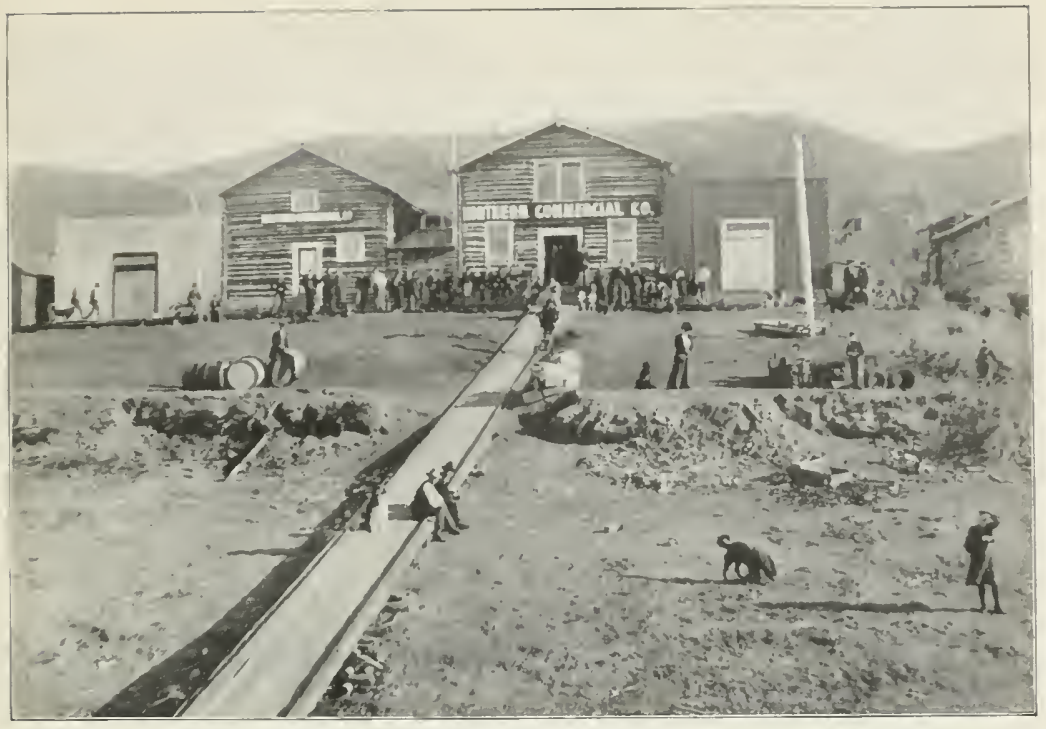

STORE AND STEAMER LANDING, RAMPART.

No. 21.

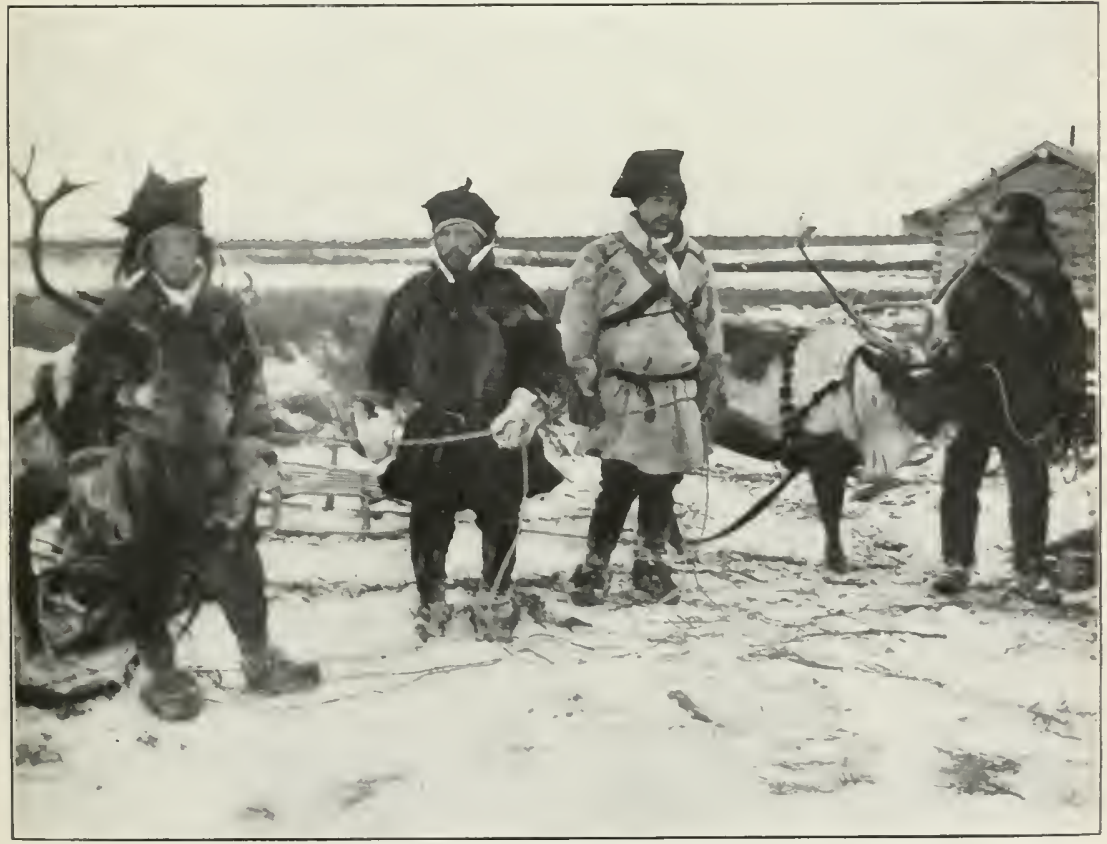

ARRIVAL OF LAPLANDERS AT BETHEL. 

ลั

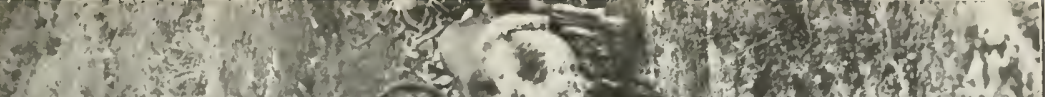

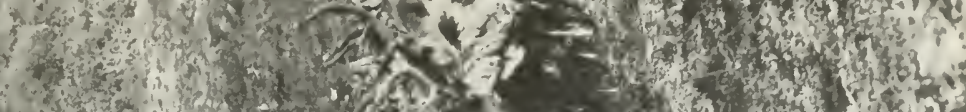

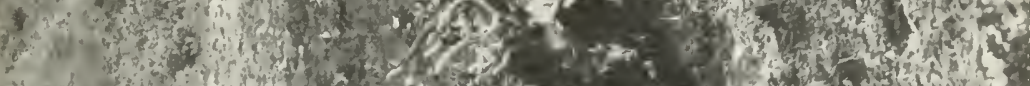

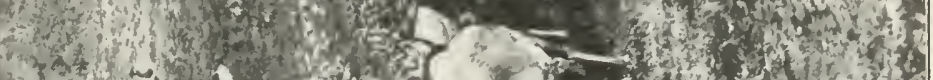

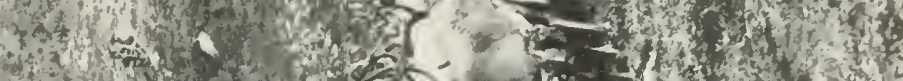

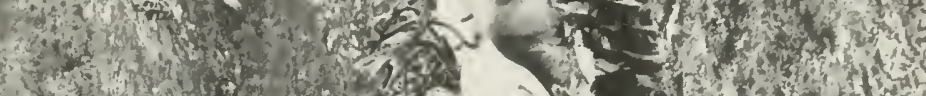

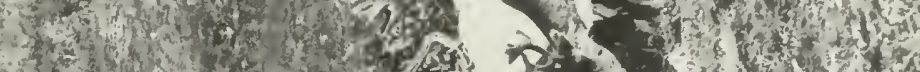

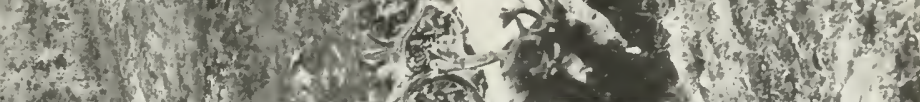

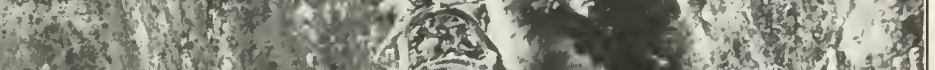

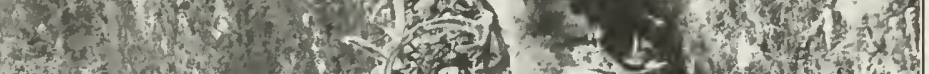

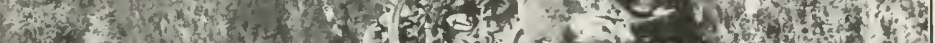

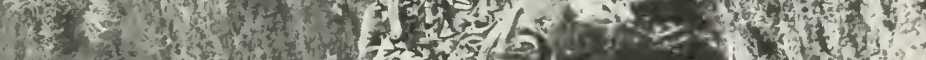

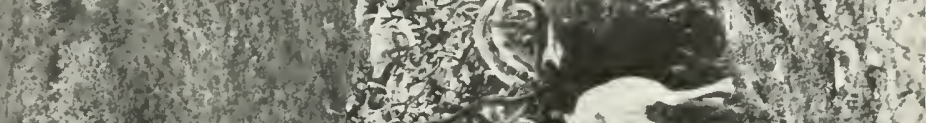

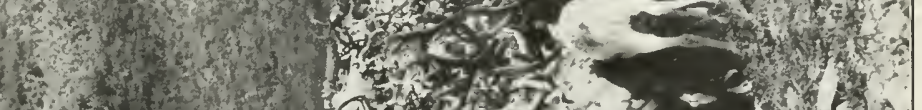

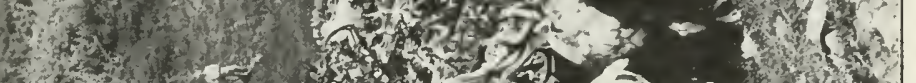

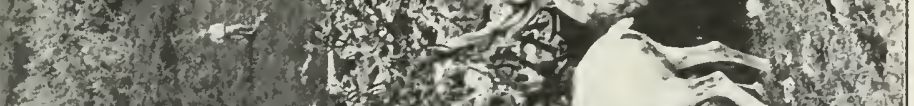

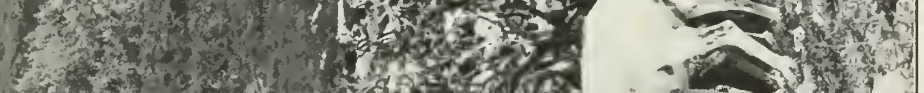

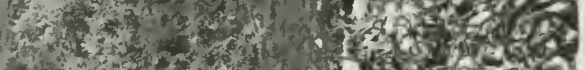

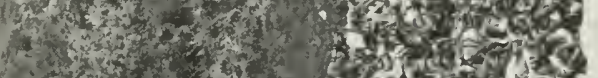

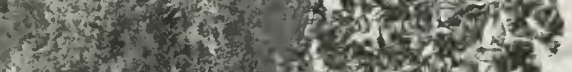

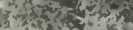
1) $x^{2}$

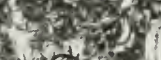

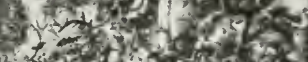

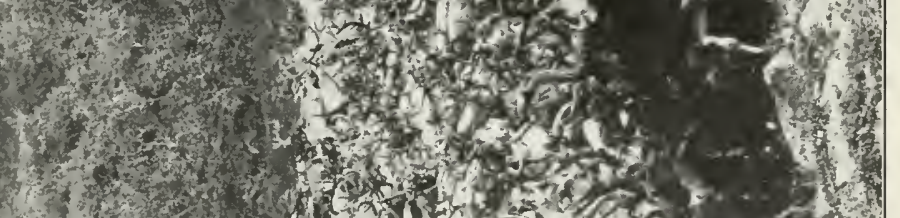
If

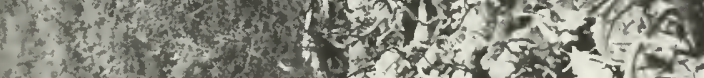

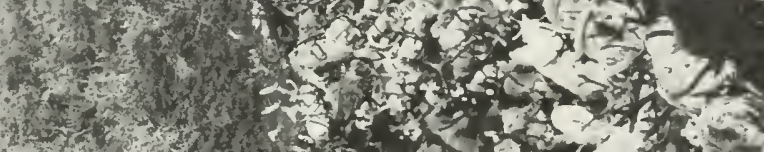

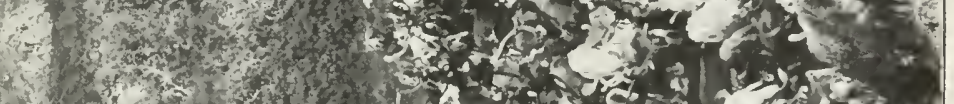

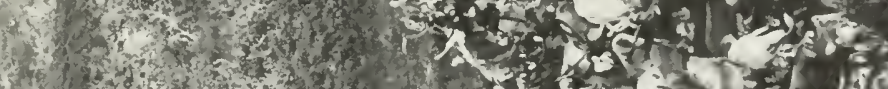

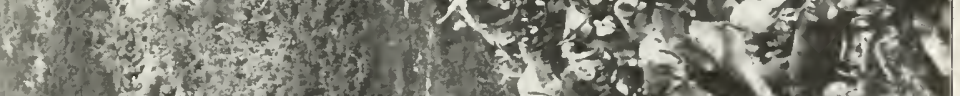

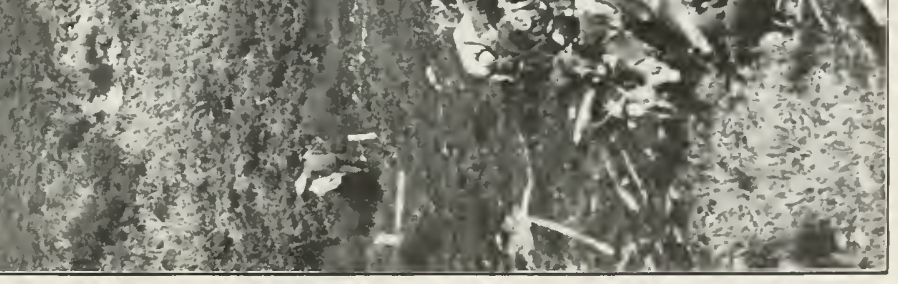

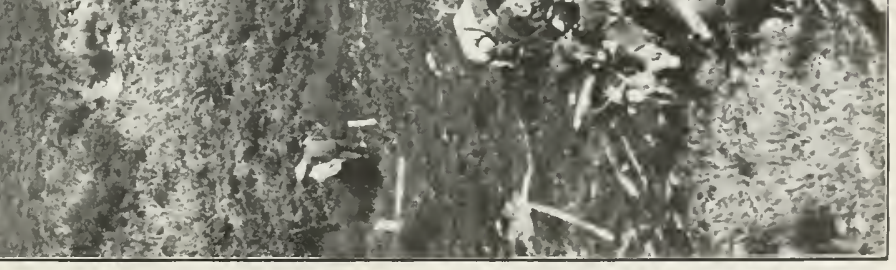




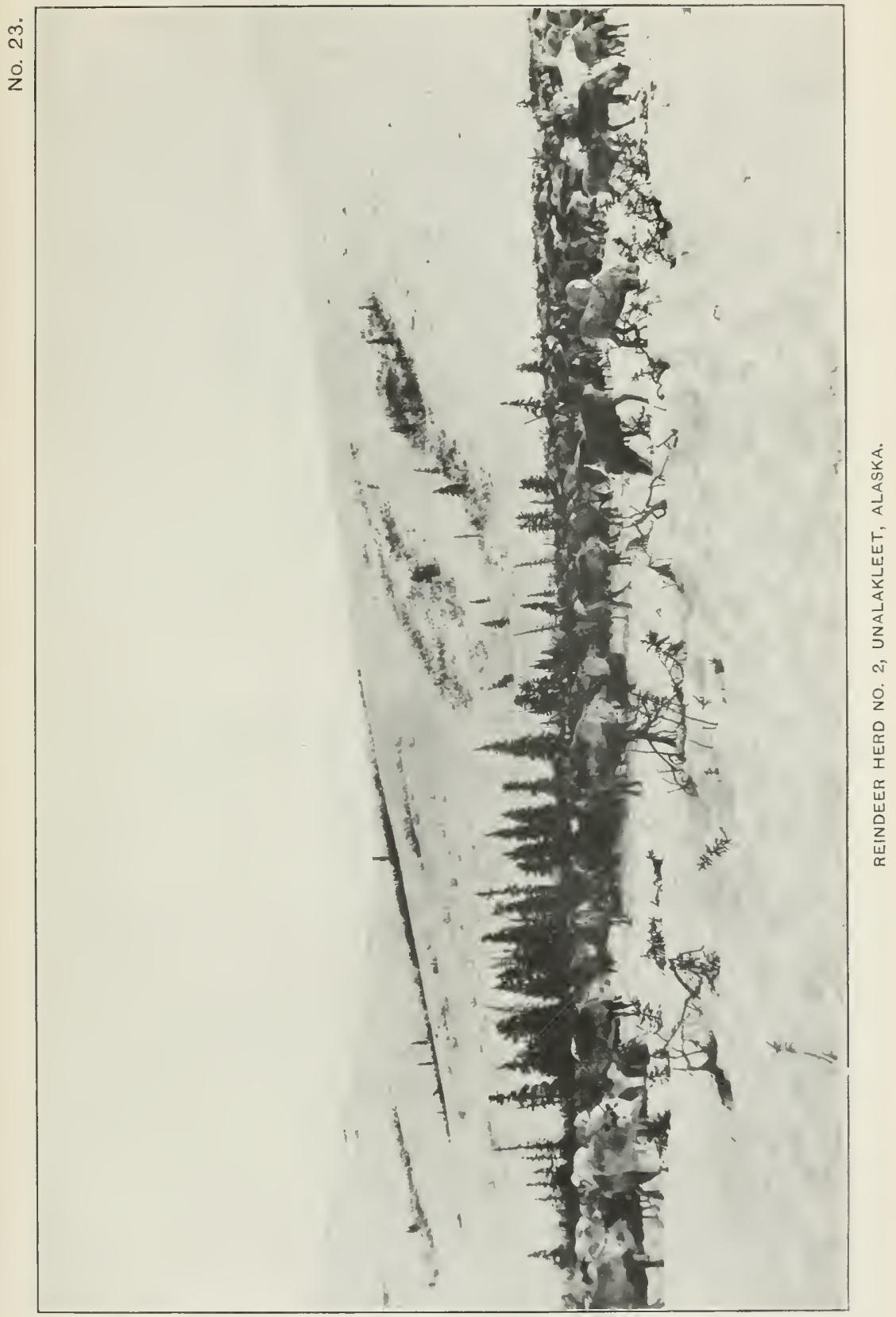





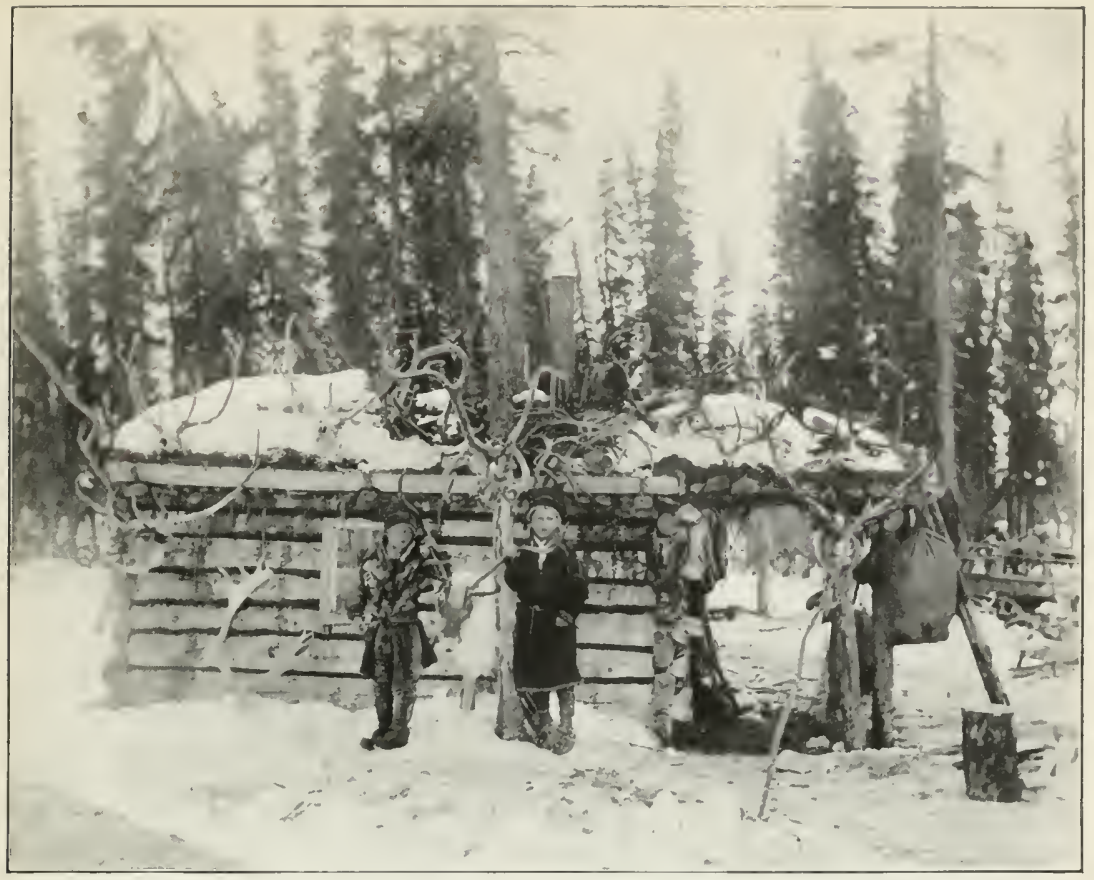

REINDEER HERDER'S HOUSE, KUSKOKWIM VALLEY.

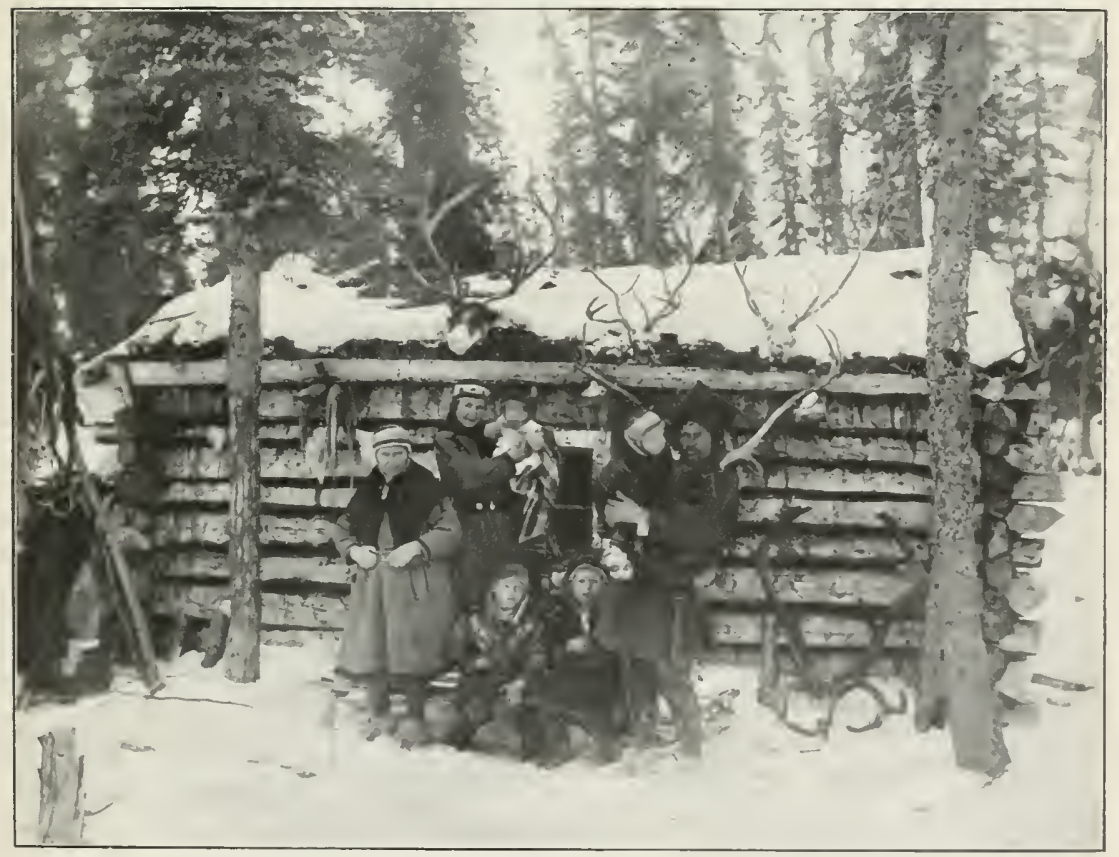

HERDER'S HOUSE NEAR BETHEL, KUSKOKWIM VALLEY. 


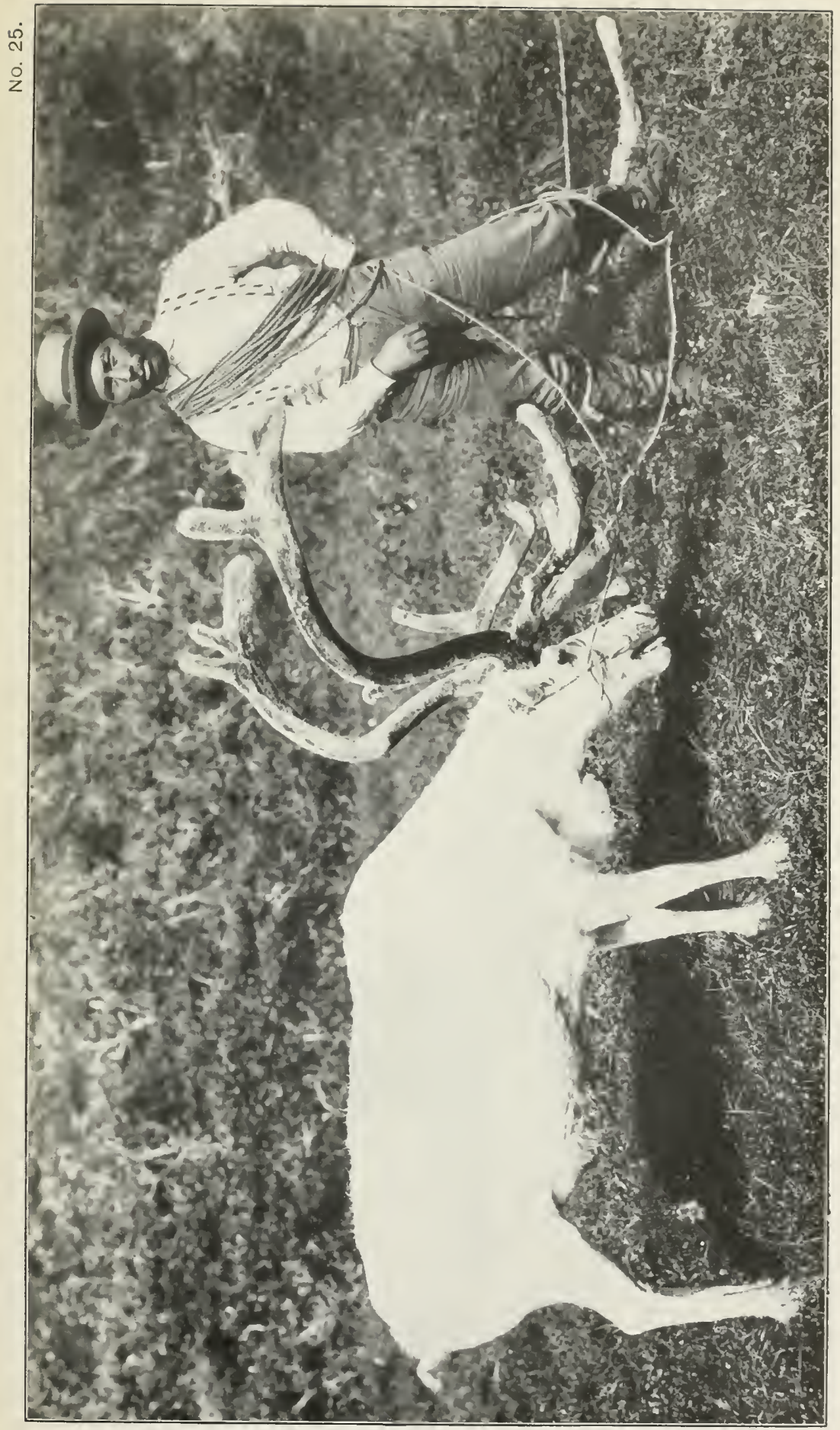



No. 26.

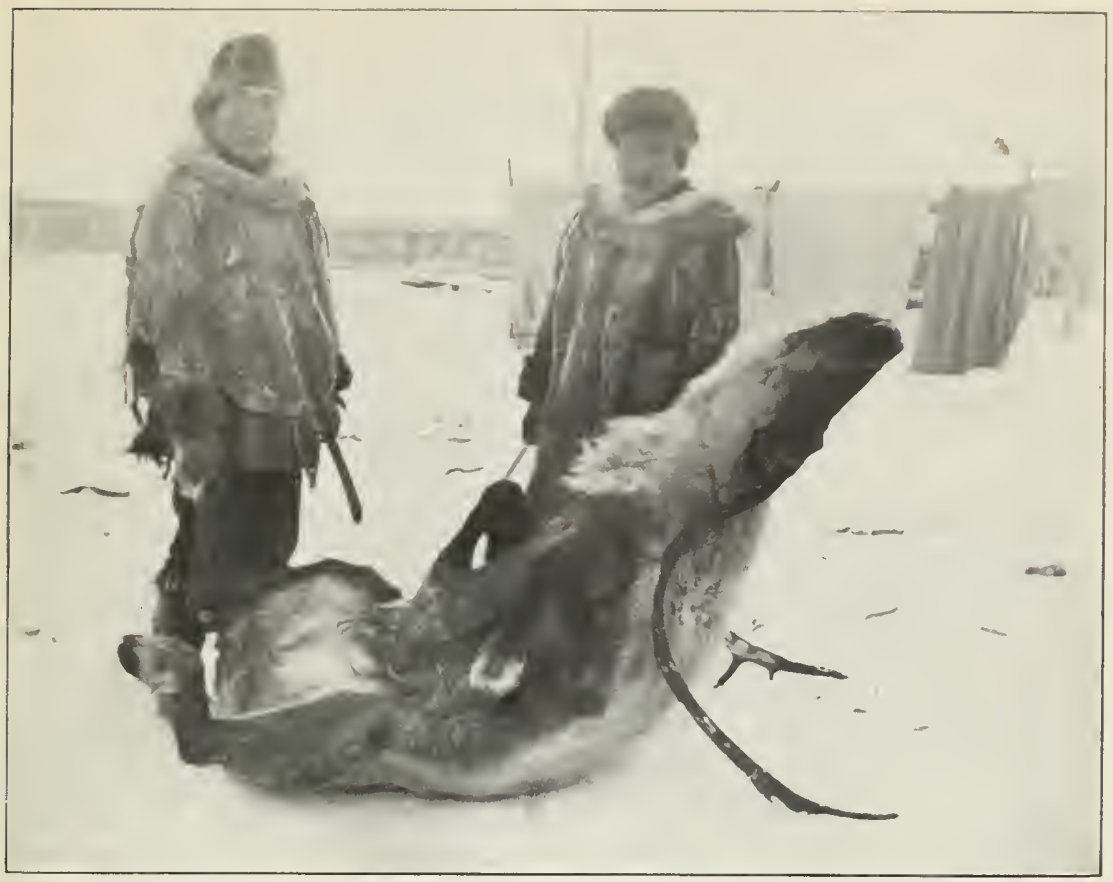

WASELY AND TOMMY, ESKIMO APPRENTICES, SKINNING A REINDEER, BETHEL.

No. 27.

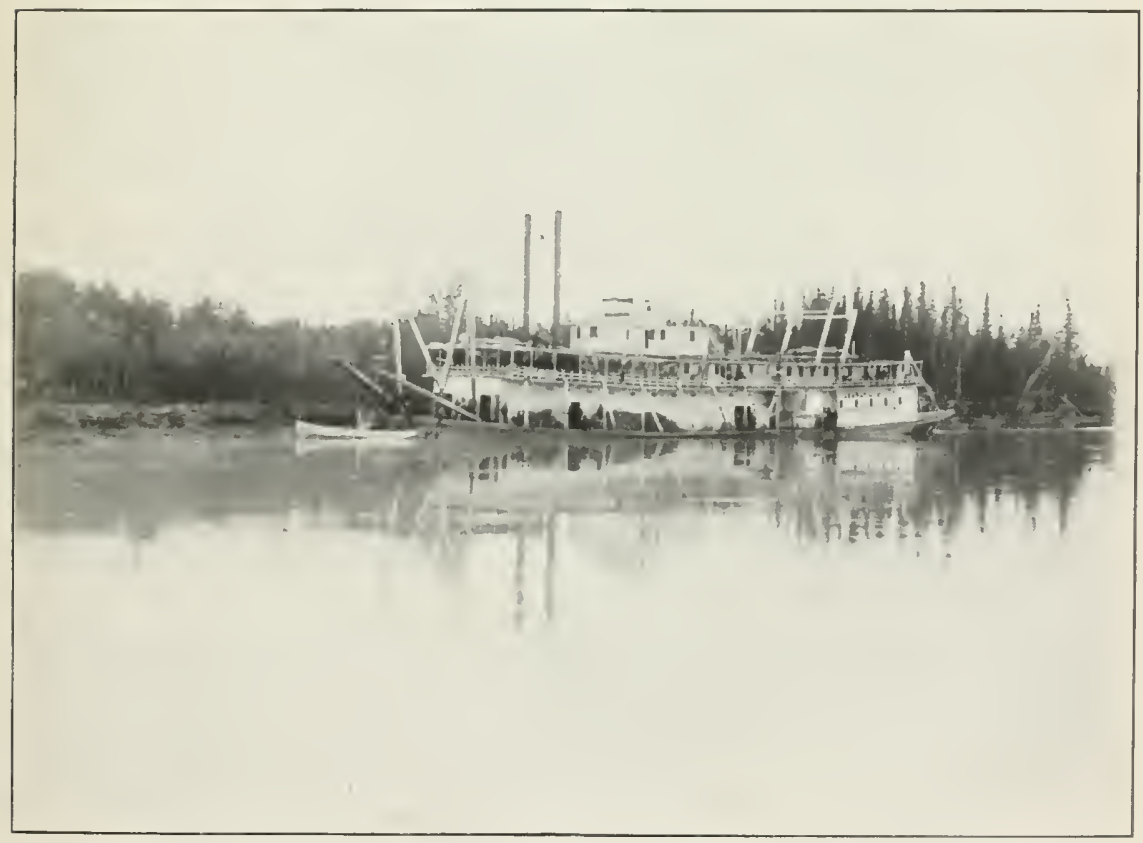

STEAMER ON THE YUKON RIVER.

Photographs by Win. Ifamilton, I'h. I). 



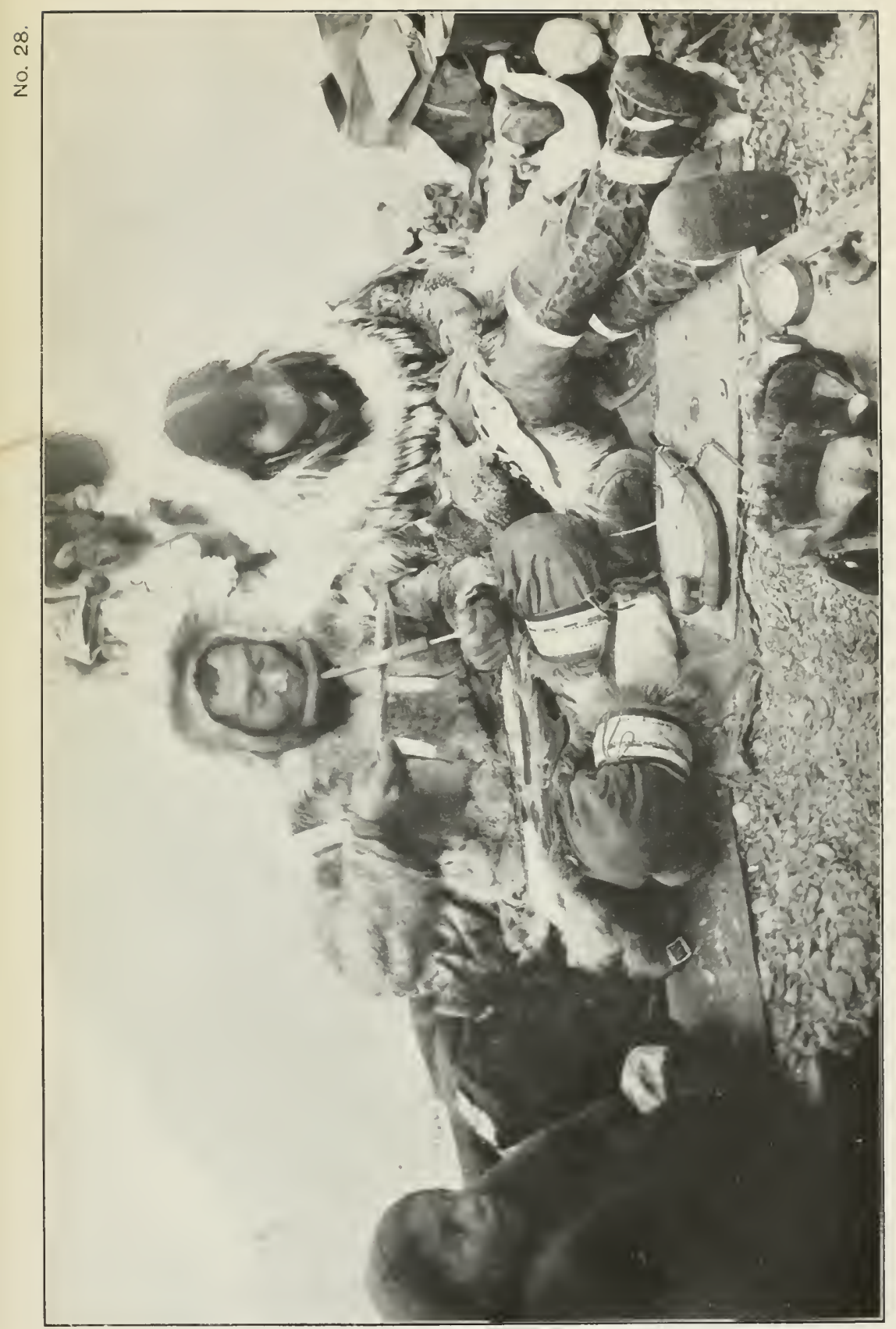



No. 29.

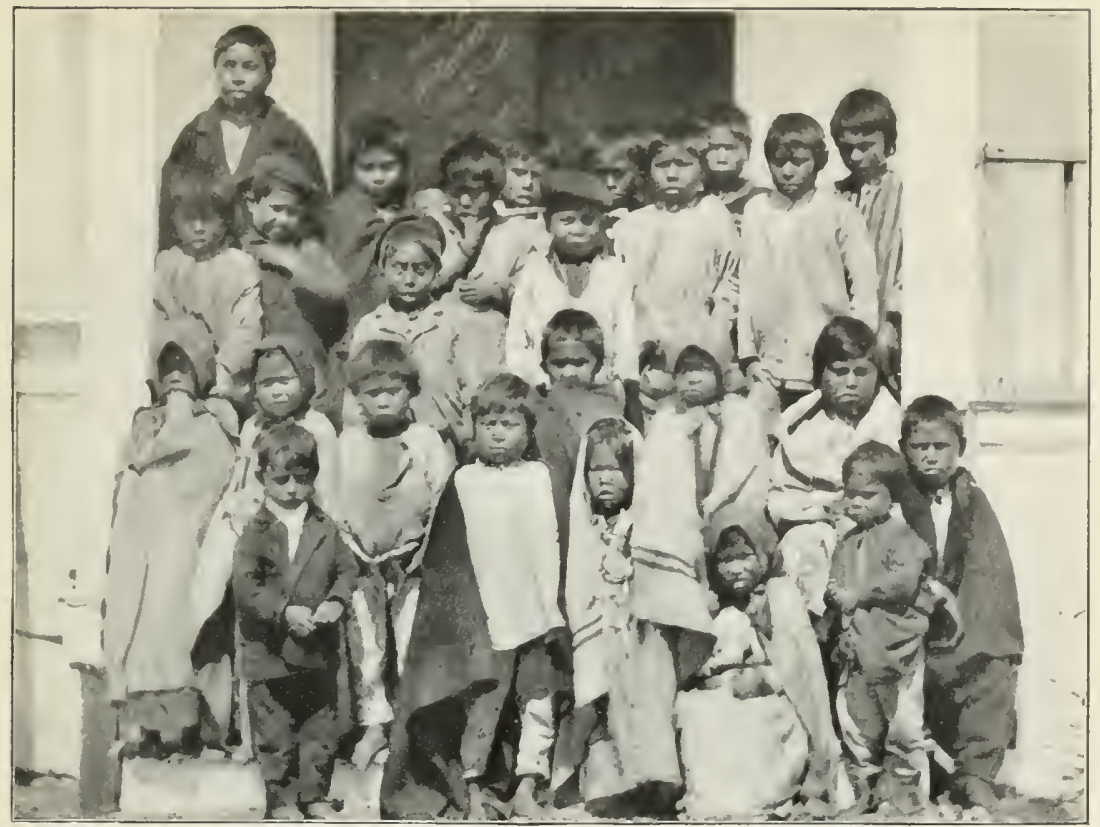

THLINGET CHILDREN ENTERING PRESBYTERIAN MISSION SCHOOL, SITKA.

No. 30 .

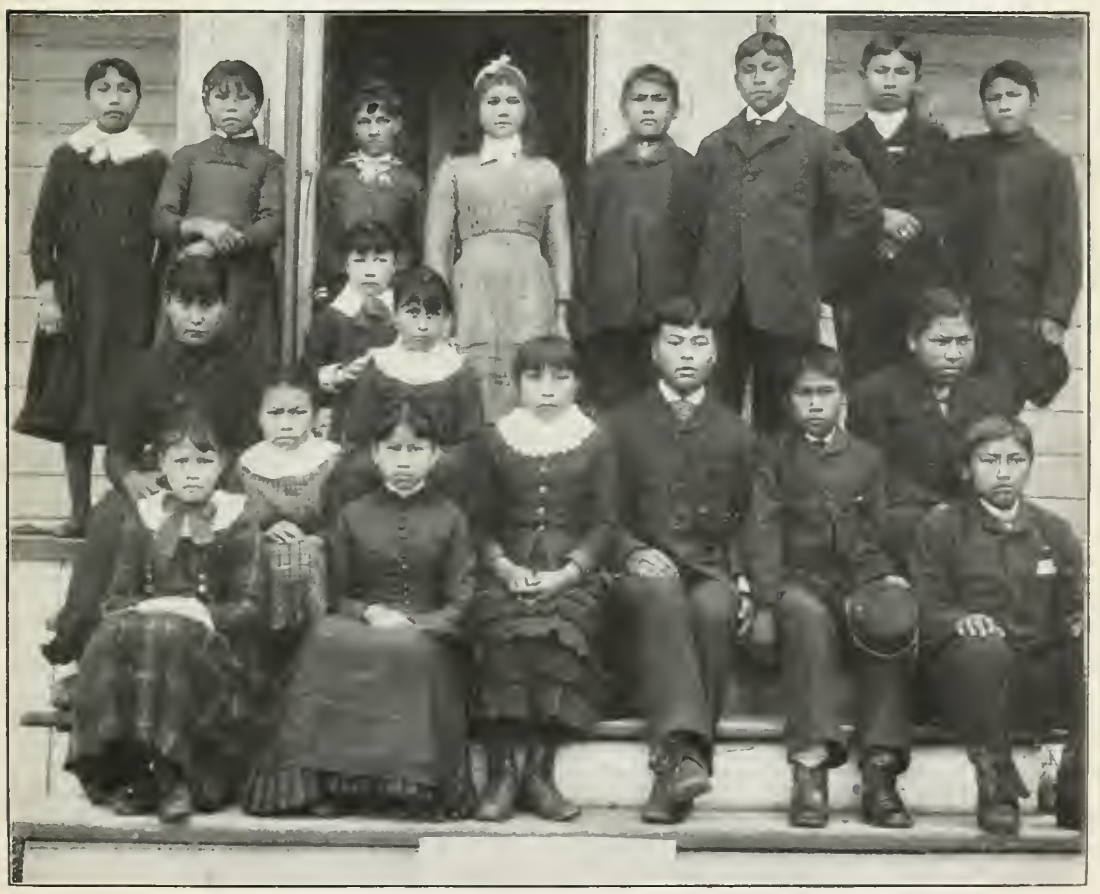

THLINGET CHILDREN TRAINED IN SITKA SCHOOL. 


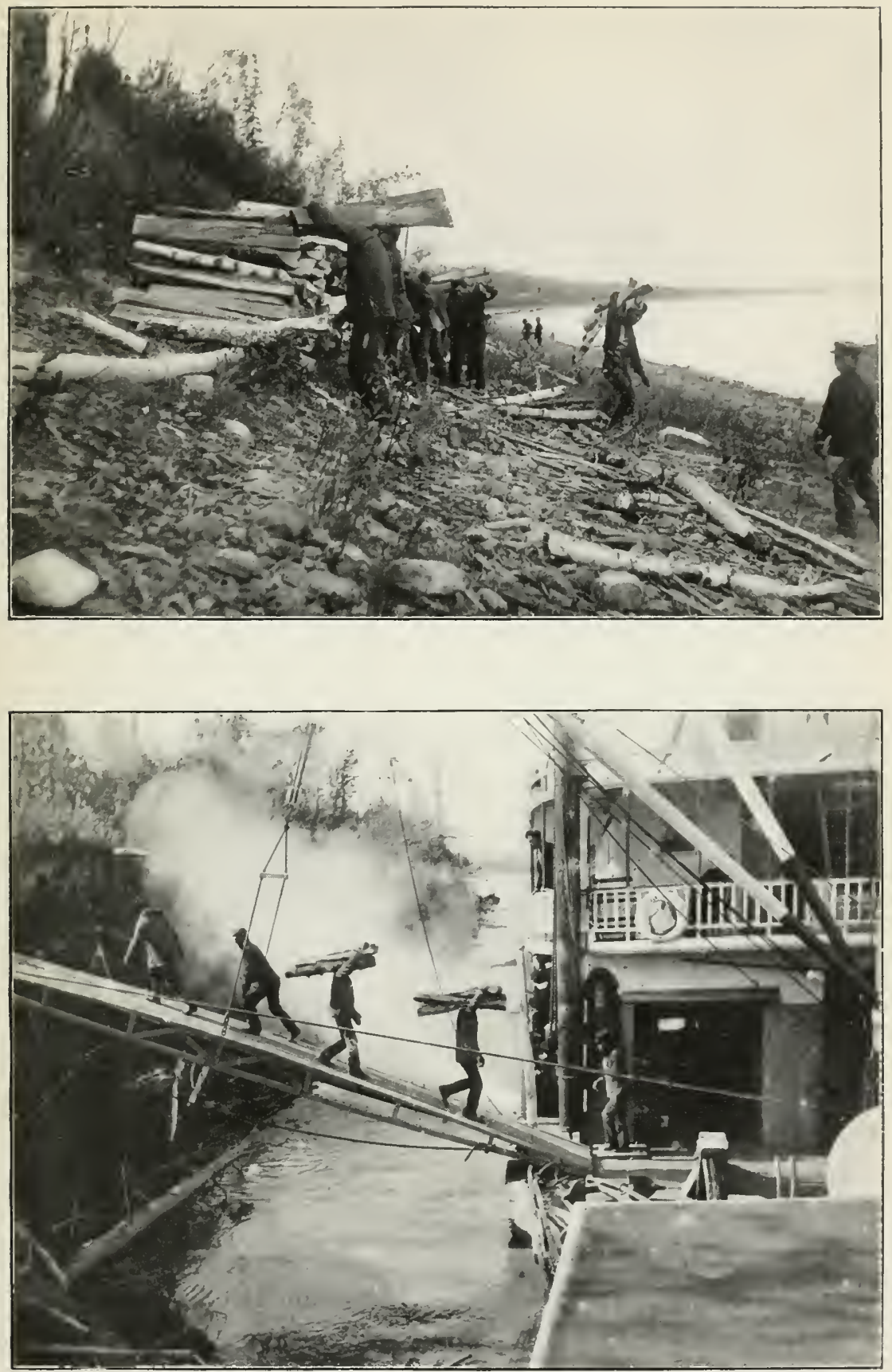

WOODING UP A STEAMER ON THE YUKON RIVER.

Photographs by $1 \mathrm{~m}, 11$ mmilton, l'h. 1 . 

No. 32.

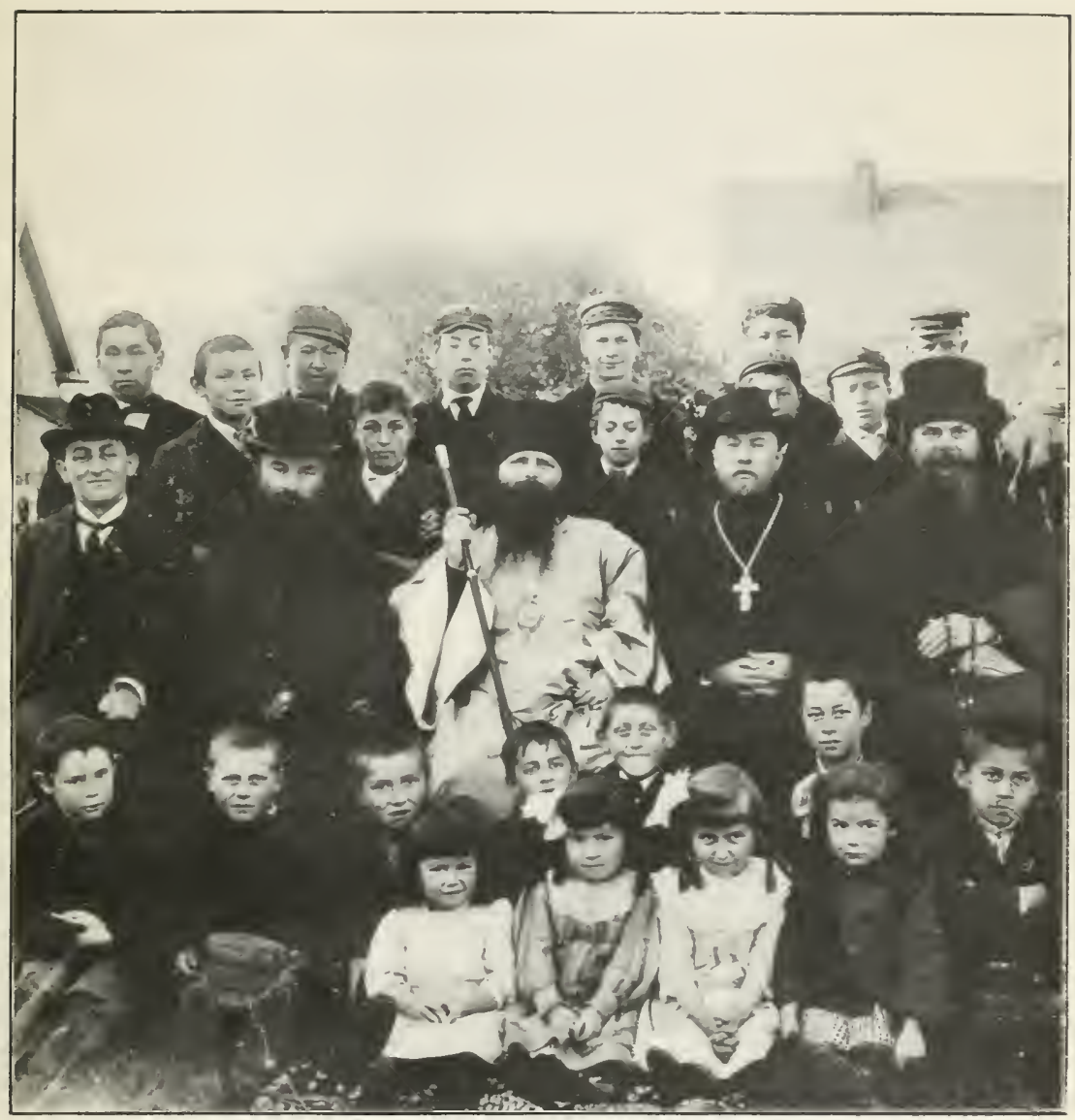

BISHOP INNOCENT AND A GROUP OF SCHOOL CHILDREN, SITKA. 



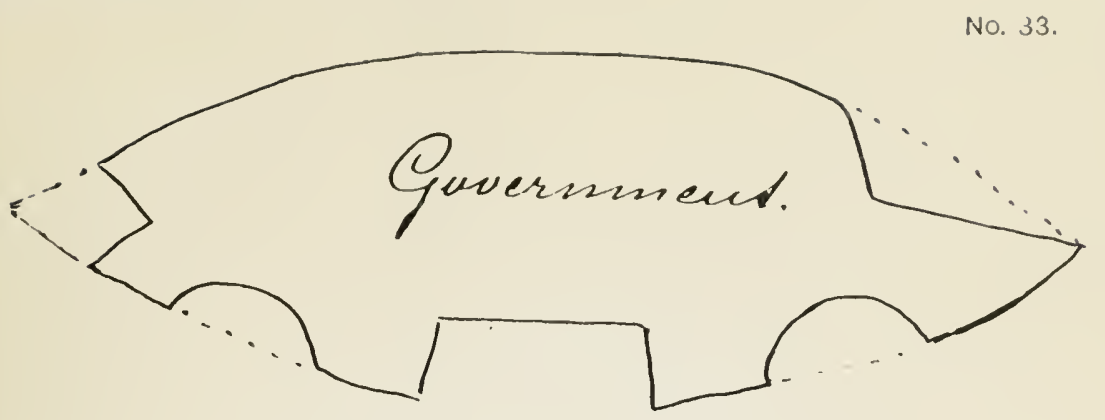

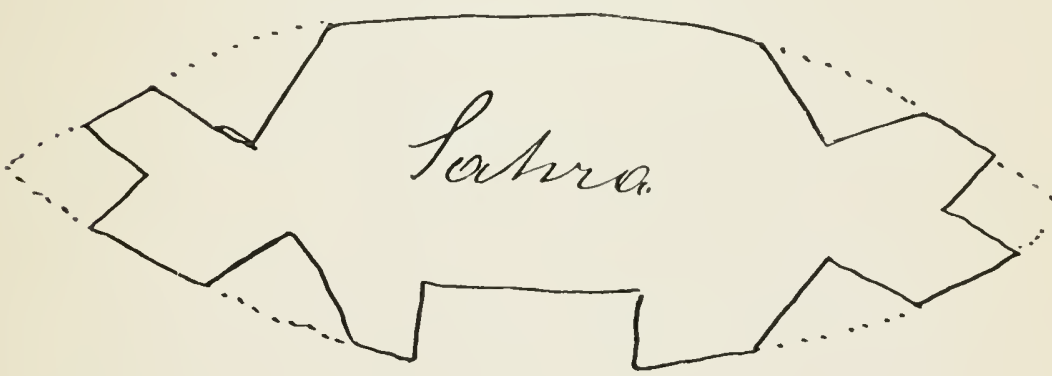

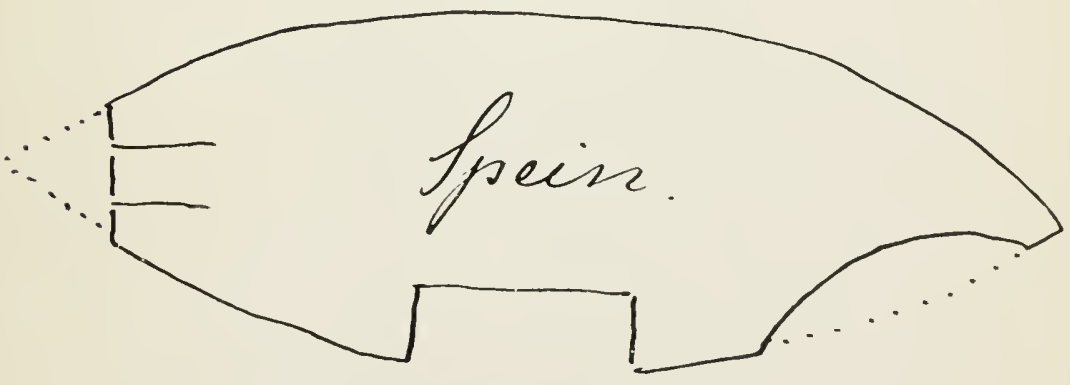

REINDEER MARKS. 


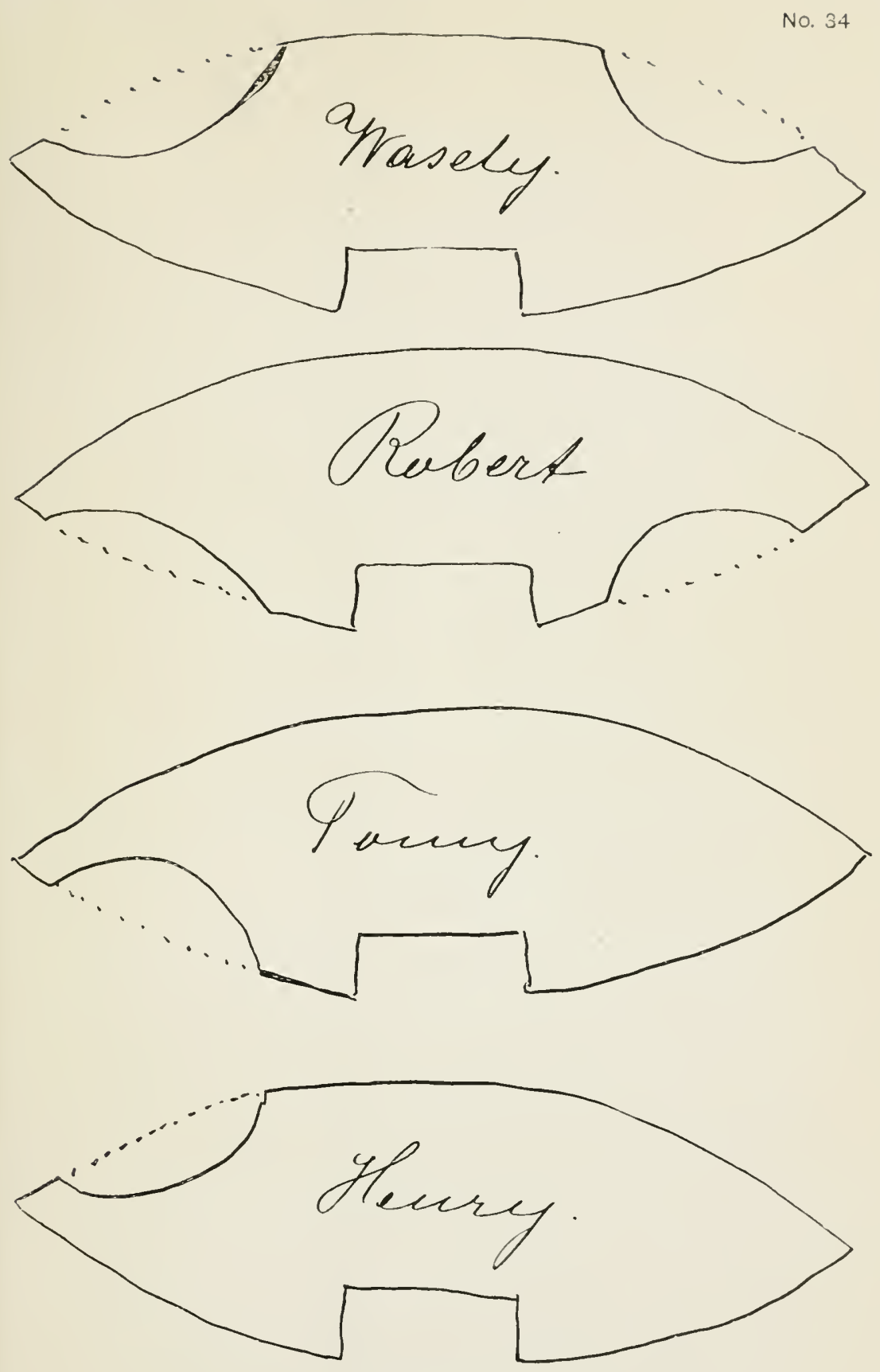

REINDEER MARKS. 



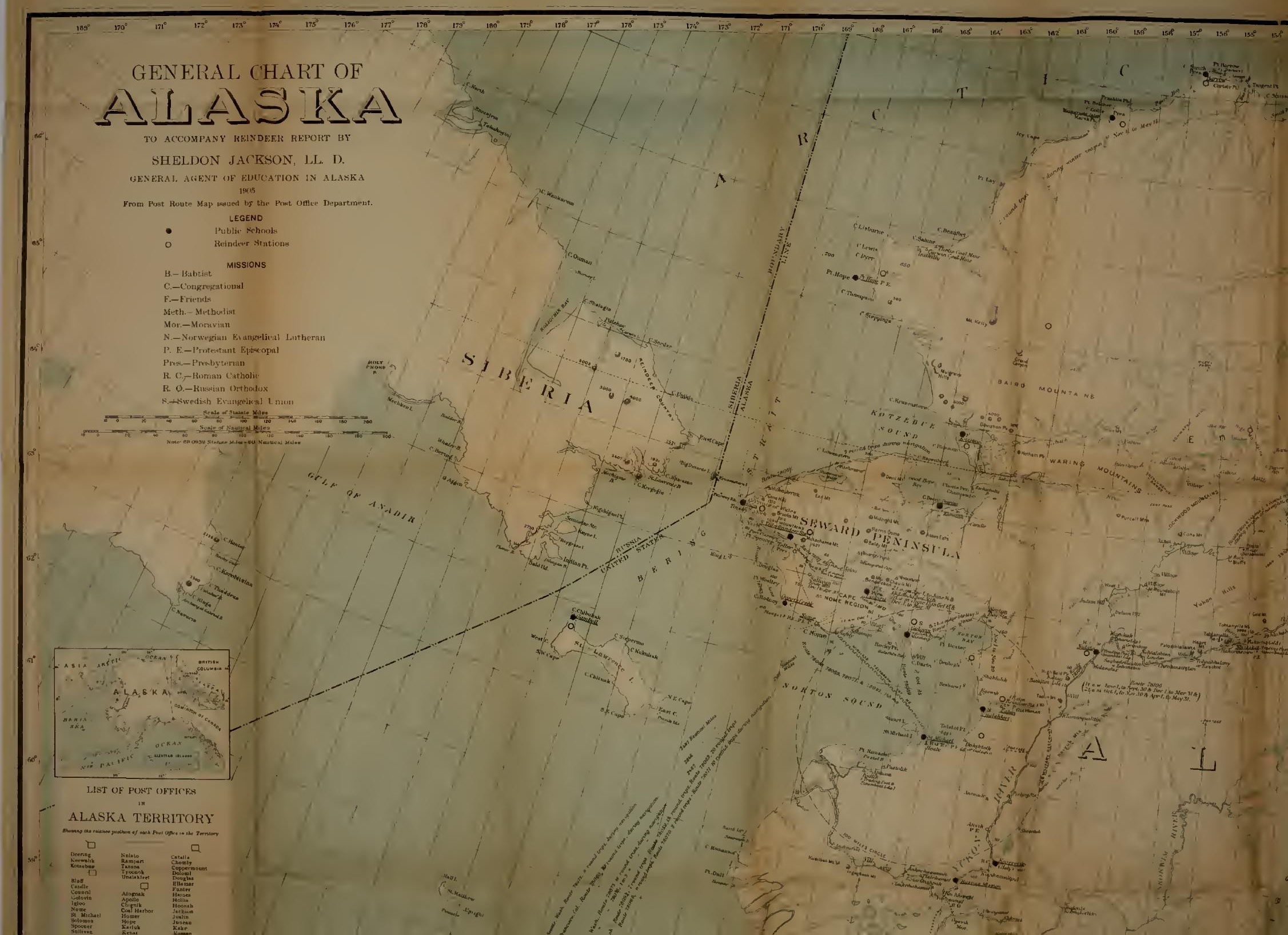




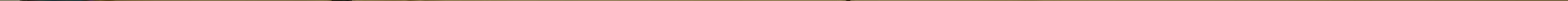




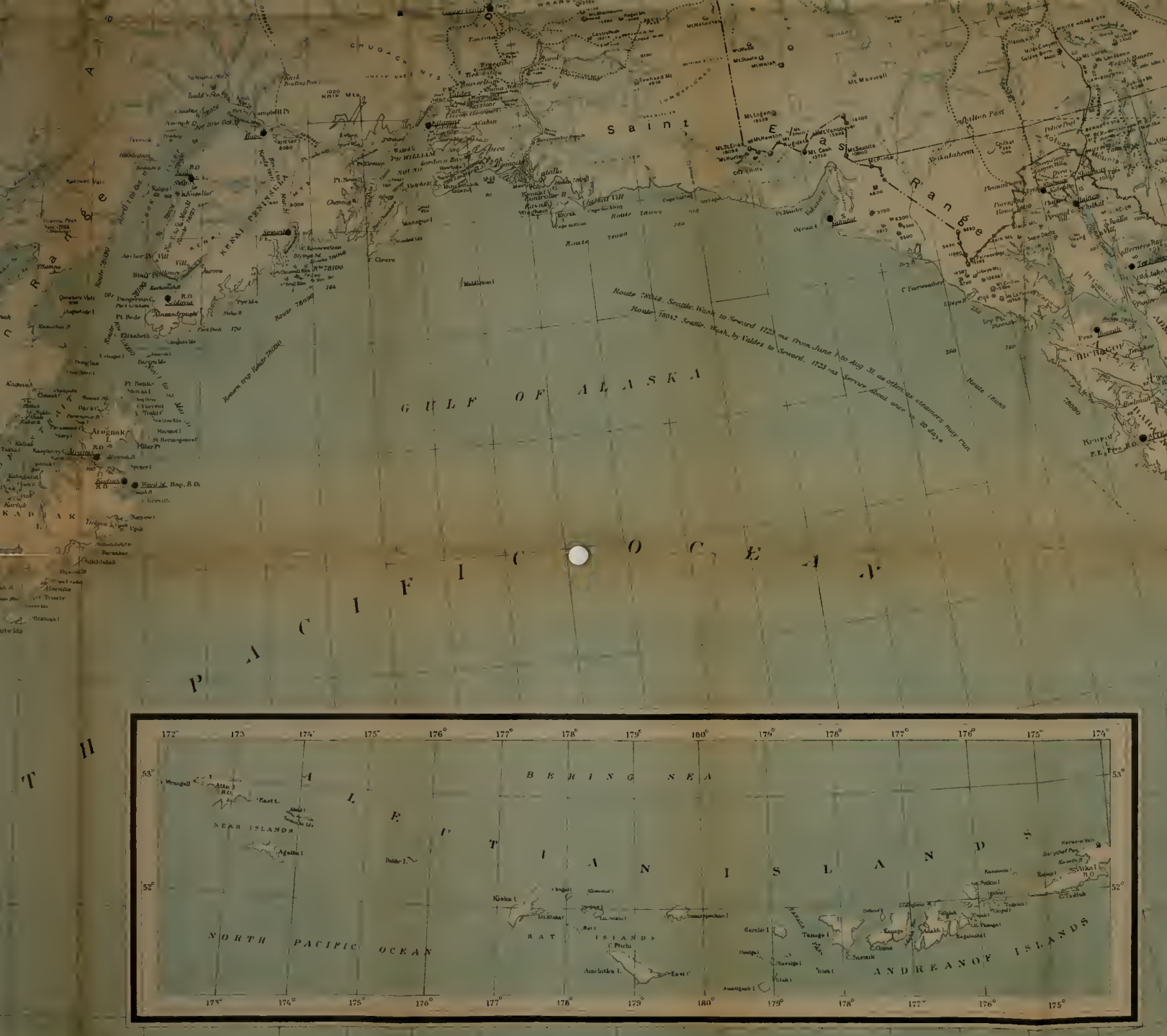





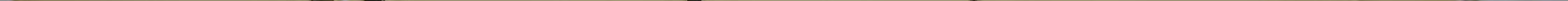


APPENDIX. 


\section{Reindeer Song}

Laplandish Song
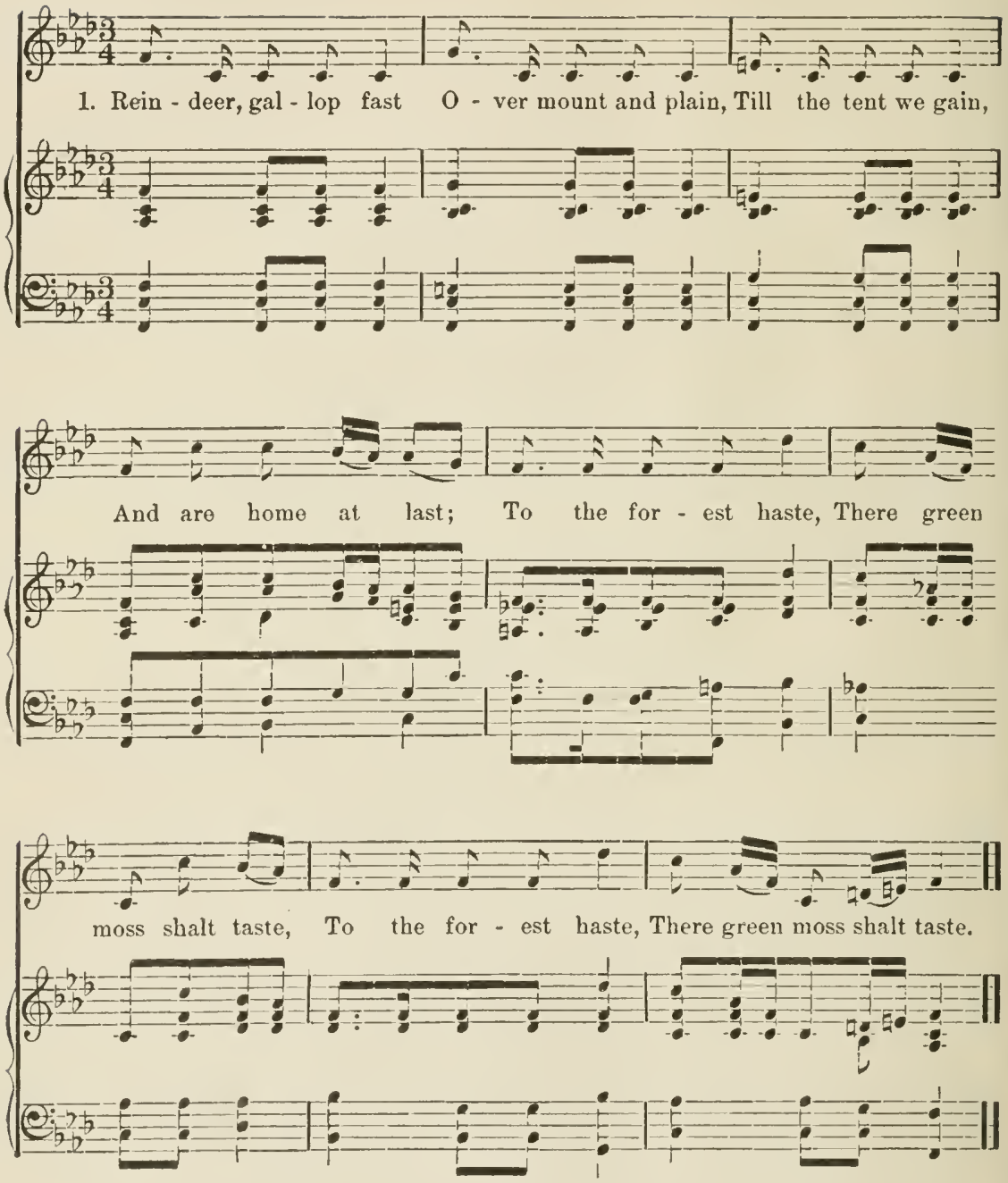

$2 \mathrm{Ab}$, how short the day, And the road how long! Come, let merry song Shorten now our way. II: Fly, my reindeer, hear, Wolves are howling near! : |
$3 \mathrm{Ah}, \mathrm{y}$ on eagle see! Could I with him hie, Like the clondlet fly From all sorrow free, I: Then my heart would rove Unto thee, my love! :||

FROM SOUTHERN WORKMAN. 


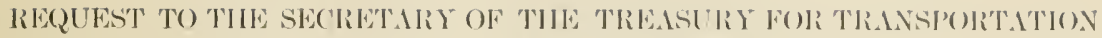
OF TIE AGFNTS OF THE BOTEAU OF EDLCATION ON THE REVENUE CUTTERS.

\section{DEPARTMENT OF THE INTERIOH, \\ BuREAT OF EntCATION, Washington, D. C., Jarch 16, 19014.}

SIr: I have the honor respeetfully to invite vour attention to the fact that for fourtecn seasons past, through the permission of the homorable the Secretary of the Treasury and the courtesy of the chief of the Revenue-Cutter Service and of the captains commanding the cutters eluising in Alaskan waters, the agent of the Burcau of Education has been able to establish and inspect schools and reindeer stations on the shores of Bering Sea and the Aretic Ocean.

As many of these schools and stations are remote from civilization and can not be reached by the regular lines of passenger steaners, this Bureau has depended for the continuance of its important work in these distant regions upon the cooperation which has been freely given during many years hy the Revenue-Cutter Service.

The assistance of the Revenue-Cutter Service is again desired for the coming season, and I therefore respectully suggest that, if it mects with your approval, a letter be witten to the honorable the Secretary of the Treasury, requesting, if eompatible with the rules of his Department,

First. That he will kindly instruct the eommanding oflicers of the revenue cutters in Alaskan waters to extend to Mr. William Hamilton, assistant agent of education for Alaska, such facilities as will assist him in his work of inspeetion and will not interfere with the duties of the revenuc cutters.

Second. It will be of especial assistance if the commanding oflicer of the U. S. S. Thetis am be instructed to conver the agent of this Bureau to Gambell, on st. Lawrence Island, either while the ressel is on her way north from Dutch Ilarbor or by making a trip from Nome at sueh time as shall be convenient for said commanding officer.

Third. That the eommanding oflicer of the Thetis be instrueted to convey from Nome to Point Barrow and St. Lawrence Island the mail for these remote plares.

Fourth. That the commanding oflicere of the Thetis be anthorizod to extend to teachers at places remote from eourts of law (where the 
only semblance of Government control is the authority exercised by the captains of the revenue (utters) such protection as he can; also that he be requested to lend his influence to prevent encroachments upon the reindeer herds fostered by the Government in northwestern Naska.

I have the honor to be, very respectfully, your obedient servant, W. T. Halisis,

Commissioner.

The Secretary of the Interior.

THE SECRETARY OF THE TREASLRY GRANTS PERMISSION FOR THE AGENTS OF THE BLREAL OF EDUCATION TO TRAIEL ON THE REVENUE CUTTERS IN ALASKAN WATERS.

\section{Treasury Departient, OfFice of the Secretary, Washington, 1L ay 2, 1904.}

SIR: Respectfully referring to your communication of Mareh 16, last, you are informed that the commanding officer of the U. S. S. Thetis (which ressel is expected to leave Honolulu, Hawaii, about the 1st of July, next, for Dutch Harbor and Point Barrow) has been directed to carry into effeet the requests made in your communication above referred to.

He has been further informed that it is expected that all fuel purchased or expended on behalf of the Department of the Interior shall be paid for by the representative of that Department.

Respeetfully,

The Secretary of tile Interior.
L. M. Sнаш,

Secretary.

LETTERS OF INSTRUCTION TO ASSISTANT AGENT OF EDLCATION IN ALASKA.

Department of the Interior,

Bureau of Education,

Washington, D. C., June 4, 1904.

SrR: With the approval of the Seeretary of the Interior, you are hercby detailed to inspect the public schools and industrial sehools in Alaska during the coming summer.

The Secretary of the Treasury has granted my request that you may be permitted to travel upon the revenue cutters during the discharge of your official duties. You will join the U.S. S. Thetis at Honolulu and proceed northward upon that vessel. Is occasion offers, you will secure transportation upon other vessels in Alaskan waters. 
Fou are direeted to visit and inspeet, an far as possible, the following schools in western and northern Maskan: Unalaska, St. Michacel, Unalakleet, Golofuin, Teller, Port Clarence, Cape Prince of Wales, Kotzelue, and Gambell (St. Lawrence Island). L'pon your return from the Bering Sea region you will visit and inspect, as far as possible, the schools in southeastern Mlaska.

Your actual necessary expenses on this tour of inspection (railroad and sleeping-ear fare, steamship fare, and subsistence) will be paid from the appropriation "Schools outside incorporated towns, Mlaskil."

You are authorized and instrueted on your journey across the continent to stop at all places where you have business in the interests of your work to transaet.

Very respectfully, yours,

Mr. Williay Hamiltox,

IT. T. Harris, Commissioner.

Assistant Agent of Education in Alaskia,

Washington, D. C.

\section{Department of the Interior, \\ Bureat of Enlcation, Washington, D. C., June S, 1904 .}

Dear Sir: After inspecting the publie and industrial schools in Alaska designated in my letter to you of June 4 , you will make a tour of the Yukon Valley, visiting the leading native villages, and where the school population is sufficient in number to justify the establishment of a school you are authorized to arrange for the erection of necessary sehool buildings and the selection of a suitable teacher.

Where you arrange for a building, keep in mind that the combined cost of a school building and teacher's residence is not to exceed $\$ 3,000$.

In the majority of places selected for schools it is probable it will be necessary to construct the buildings of logs, and on that account it may be possible for you to arrange with some responsible trading company to ereet the log buildings at a much lower price than frame buildings would cost.

Where you fail to find a suitable teacher in the community, telegraph this Office, in order that the teacher may be sent from the states in time for the opening of school in the fall.

Very respectfully, yours,

Mr. Willian Hamilton, W. T. Harris, Commissioner. Assistant Agent of Education in Alaska,

Washington, D.C. 
ITINERARY OF W'HLLAM IIAMILTON, PII. D.

DEPARTMENT OF THE INTERIOR,

Bureat of Eutchton, Alaska Division,

Wrashington, D. C., December 8,1904 .

Sin: In compliance with your instructions to join the U. S. S. Thetis for the ammual risit of inspection of Cinited States public schools in western Mlaska, and to make the tour of the Yukon River with a view of atsecrtaining the points at which it would be advisable to organize schools, I left Washington on June S, arriving at San Francisco five days later.

On June 16 I lelt San Francisco on the steamer Tentura, which entered the harbor of Honolulu on the morning of June 22. The Thetis was not there when the I'entura arrived, but returned to Honolulu from a short cmise to Midway and Lisiansky islands a few days later.

While the Thetis was taking on coal and stores for the arctic cruise we enjoyed many courtesies from friends in Honolulu and visited many places of interest on the island of Oahu. On the morning of .July 3 the Thetis steamed out of the harbor of Honolulu with Dutch Ilarbor, on the Aleutian Islands, as her objective point. The roster of the officels of the Thetis was as follows: Capt. Oscar C. Hamlet, commanding; executive oflicer, First I.ieut. Charles E. Johnston; navigator, Second Lient. Ermest F. Mear; Second Lieut., Francis R. Shoemaker; 'Third Lieut., IIram R. Searles; chief engincer, Levin T. Jones; assistant engineers, William L. Maxwell and W. E. Davis; surgeon, Samuel J. Call, M. D.

For several hours after leaving Ifonolulu we skirted the palmfringed shores of the island of Oahu. Toward evening we headed northward, and the wooded shores gradually disappeared below the horizon.

For the first two days we were in the track of the steady trade winds and good progress was made. On the third day the wind died down; then for three days we ghided over the smooth seas of the doldrums. Next came the fresh breezes of the north Pacific, and onee more, with all sails set, we proceeded rapidly northward. On July 13 we encountered the fog that almost constantly hangs over the waters adjacent to the Aleutian Islands. At slow speed, the fog whistle sounding, the steamer felt her way along. Sometimes, steaming through the fog, we came suddenly upon flocks of whale birds resting upon the smooth waters, that fled at our approach with a mighty fluttering of wings. Night fell before we sighted land, and, desiring to go through Tnimak Pass and enter Bering Sea by daylight, at $10 \mathrm{p}$. m. the captain headed away from land, and during the darkness of the night we stood ofl and on at a safe 
distance from the danererous rocks of the islands. At dawn on the 1tth the Thetis headed for Unimak Pass onec more, the for still hiding everything from view. Fortunately, about 6 o'clork, throuch a sudden rift, the navigatine offecer caucht a crlimpse of a headland, which he rightly judged to be one of the rapes at the entrance of the pass. 'Then the inevitablo fog closed down again, and through its clammy folds we steamed cautiously toward land. Soon the Scotch Cap light, with its group of buildings, was sighted, and we steamed through Lnimak Pass into Brring Sea and turned westward toward Tnalaska Harbor. Feeling our way from one dark, fourwreathed headland to another, during the afternoon we sutered Unalaska Bay and at is p. m. ticel 11) at the Duteh Harbor wharf".

The Thetis remained in this sheltered harbor for nine days, making repairs to her machinery and taking on a supply of coal. During this time I inspected the public schools in the neighboring village of [nalaska, and had frequent consultations with Mr. and Mrs. William A. Davis, the tearehers, and with Mr. N. Gray and Dr. 1. II. Newhall, the mombers of the local school committee.

On July 24, the repairs completed and the bunkers full of coal, the Thetis resumed hel cruise. By the courtesy of' Captain Ilannlet, the Right Rer. Innocent, who recently had been appointed to the oversight of the Russian Orthodox (hurches in Mlaska, and the Rev. R. I. Orlofl, of the same (hurch, were received on board. Bishop) Innocent was making his first visitation to the churches in his vast diocese, and was desirous of taking this opportunity to reach the Russian rhurches on the seal islands St. Paul and St. George.

After rounding Cape Cheerlul, one of the capes at the entrance to the bay, we ran into the fog. On the next day, when, accorrling to the ealculations of the navigating oflicer, we should be rery near St. George Island, under a slow bell the ressel folt her way through the fog with the utmost caution. The lead was kept going continuously; every three minutes there was a blast from the fog whistle, and sometimes through the impenetrable fog (ame the answering echoes from the precipitous rlifts of the islands. Startled sea crulls came wheeling ont from the mist; tide rips indieated tho proximity of a headland, and in the ofling wo caught sight of a faint line of breakers and heard their dull roar. Toward afternoon the fog lilted, and it was possible to locate the village on St. Geolege Island, a cluster of white luuldings on the grassy inillside. Soon alter the anchor was dropped a boat from the village came alongside, in which were Major Clark and Mr. Chichester, the Treasury agents on the island, Father Kedrorsky, the Russian pricst, and a number of matives who desired the services of the ship's surgeon. For the next few hours Doctor Call was an exceedingly busy man, pulling teeth and prescribing for many and various ailnents. No ship 
had visited the island for many weoks; the mail whih the Thetis brought and the news from the outside world were eagerly received by our exiled friends. Bishop Innocent went ashore without delay in order to hold services; the pealing of the bells of the little church on the hillsicle that greeted him when he stepped ashore came out to us over the gloomy waters. We could see the natives flocking to church from all directions.

The following morning a party from the ship went ashore and witnessed a "seal killing." This work is done entirely on land, and has been reduced to a science. The only persons permitted to kill and skin the seals, to the number of the annual quota prescribed by the Treasury Department, are the stalwart Aleuts of the islands, who, by life-long practice, have become experts in their profession.

The first step in the process is to segregate from the main herd some of the young male seals up to the age of 4 years. This is easily accomplished, as it is the habit of these "bachelor" seals to congregate upon the mossy ground in the rear of the "rookeries," the groups of seal families that fringe the beach. Crawling between the rookeries and the bachelor seals, the Aleuts drive the latter inland toward the killing ground. Not more than 5 or 6 miles are accomplished in a day, as the seals travel laboriously on land and easily become overheated, thus impairing the quality of their skins. Rainy or overcast weather is chosen for this driving whenever possible. The seals are often allowed to rest overnight in order that they may thoroughly cool off. Occasional whistling by their guides prevents them from straying. In the morning the seal killers appear with their long clubs and sharp knives. Small groups of 20 or 30 seal are separated from their companions and the slaughter begins. Any seal which to the eyes of the experienced officials appears to be either above or below the specified age or weight is allowed to scamper off to shore, and plunging into the waves goes rapidly on its way rejoicing. 'The less-fortunate seals are killed by a sharp blow on the head from a heavy club, which fractures the skull and produces instant death. The men with the clubs are immediately followed by the skinners, who with great dexterity divest the carcass of its valuable skin. The wives and daughters of the natives linger near and carry away to their homes large pieces of seal meat and blubber.

The skins are taken to salt houses and salted down under leavy pressure; then they are tied in bundles ol two each, with the fur side inside, and are ready for shipment. Formerly the company leasing the seal islands was permitted to kill as many as 100,000 seal per annum. Pelagic sealing has so leduced the number of the seal that during the current year the North American Commercial Company, the present lessee of the islands, is limited to 15,000 . 


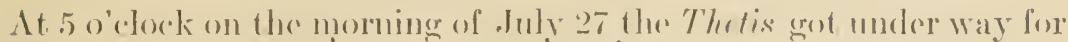
St. Paul Island. 'The fore still hume over the sea and a heavy gromed swell prevaled. Igain there was cautious navigation and careful sounding. Ibout noon a faint line of surf could be distinguished, and as we neared land the harking of the seals was heard. The waters shoaled rapidly and soon the dark elifts inclosing Lukanin Bay, to the northeast of the village of St. Paul, could be made out. Cautiously following the dinly outlined clifl's, toward evening the village was reached and anchor was dropped about $1 \frac{1}{2}$ miles from shore. The fog whistle had given the villagers notice of our approach and soon a boat came out to the ship bringing Mr. Wr. J. Lembke, Treasury agent in charge of the Seal Islands, and some of his friends. Here again the mail was eagerly received. Later in the evening Bishop Innocent and Father Orloff went to shore, the latter to resume charce of his church and the former to hold services and to make the aequaintance of his people.

At 9 p. 1 . the Bishop returned to the ship and without delay anchor was weighed and once more we glided into the all-cnveloping fog with St. Lawrence Island as our objective point.

For the next two days we steamed steadily northward seeing nothing except fog. The navigating officer had not been able to get a glimpse of the sun since we left Dutch Harbor on July 24; he had been compelled to depend entirely upon dead reckoning. The swift, irregular currents which prevail in shallow Bering Sea make navigation in its fog-ridden water's a matter of great difficulty.

During the morning of July 30, the dark cliffs of St. Lawrence Island loomed up. This cheerless, desolate island is treeless and destitute of regetation of any kind save grass and reindeer moss which, as pasture for the herds of reindeer, redeem it from absolute worthlessness. It is girded by a line of monotonous clifts and there are few landmarks to aid the navigator. It was difficult to tell just what part of the long coast line we had sighted. The navigator in Bering Sea must be gifted with a sixth sense, and from a glimpse of dark rock seen for an instant through a rift in the fog must be able mentally to construct a whole coast line.

By good fortune we made the village of Gambell, near Northwest Cape, and eame to anchor about a mile from shore. Vigorous blasts from the fog whistle soon brought out Dr. Edgar O. Campbell, who is the public school-teacher, medieal missionary, and superintendent of the reindeer herds on the island. I accompanied Doctor Camploell back to the village and extended to him and Mrs. Campbell a very kind invitation from Captain Hamlet to eome on board the Thetis for a voyage to the mainland, where the Thetis would leare them for three or four weeks while she continued her cruise to Point Barrow and return them to St. Lawrence Island when on her way south. 
During eight months of each year St. Lawrence Island is an island in the ice-bound sea, absolutely inaccessible from the outside world. During the short season of open navigation in midsummer the only visitors to the island are a few of the aretic whalers on their way to and from the whaling grounds beyond the Aretic Circle, the revenue cutter bringing the annual mail, and the schooner delivering the supplies for the school and reindeer station. Doctor Campbell and Mrs. Campletl had been for three years constantly on this desolate island.

Captain Hamlet's invitation was eagerly accepted. While I inspeeted the school and Government property at the station Doctor Campbell and Mrs. Campbell hastily made preparations for the summer's outing, and during the evening accompanied me back to the Thetis. Three of the native boys from St. Lawrence Island were also taken on board and entered upon the ship's roster as berth-deck boys, with a view to promotion if their services were satisfactory. Three boys from Unalaska who were given similar employment on the Thetis during the summer of 1903 were by this time good seamen. The opportunity thus given to the natives to advance themselves is most praiseworthy and ean not fail to be an incentive to all the Eskimo young men with whom they come in contact.

At 9 p. m., July 31, the Thetis dropped anchor off Nome, and early on the following morning we reeeived on board several sacks of mail for St. Lawrence Island and for the isolated settlements on the shores of Bering Sea and the Aretic Ocean, also many letters, magazines, and newspapers for the ship's company.

At noon of same day we were again underway, steaming southward through Norton Sound en route for St. Michael, 60 miles nortli of the delta of the Yukon River. In approaching St. Michael it is necessary to give a wide berth to the mud flats making out from the delta of the Yukon. The harbor is unsafe in bad weather, both from want of protection and shallow water, the depth at the usual anchorages, 2 or 3 miles from shore, ranging from 3 to 4 fathoms only. When the sea rises it is frequently necessary to shift anchor or head out into deep water. The first ocean steamers from Seattle or San Franciseo, making their way through the ice fickls of Bering Sea, usually arrive at St. Michael about the end of June. From that time until the closing of the harbor by ice in October, St. Michael is the place of transfer of passengers and freight from the ocean-going ressels to the lightdraft, stern-wheel steamers which ascend the mighty Yukon and its tributaries to the mining settlements on their shores. Until the completion of the White Pass and Yukon Railway, from White IIorse, at the head of river navigation, to Skagway, on Lymn Canal, St. Michael was the only base of supply for the Yukon Valley and the outlet for its trade.

While waiting for the departure of the river steamer, with the aid 
of Maj. W. L. Burk, I'. S. Army, and Mr. Lawrence M. Sohring, our local school committee lor Sit. Micharel, I made arrangements for the storing of the lumber and materials for the public school building that was to be erected at St. Michacl during the summer, and for the oponing of the new term of school in september. ()n Lugust 3, Mr. Hedley E. Redmyer and his assistant, Mr. I Iatta, who are to transpent a herd of reindeer from Bethed to Copper ('onter, arrived on one of the ocean steamers. At St. Michacl we purchased additional supplies needed for this expedition and had many ronsultations regarding their enterprise.

At 2 o'clock on the morning of August 7 , the river steamer Rock Island, Capt. A. E. Le Ballister, commanding, started on her voyage. Sometimes it is necessary for the river steamer's, whose draft of only 4 or 5 feet renders it dangerous for then to encounter the 60 miles of open sea between St. Michael and the mouth of the Yukon, to wait at St. Michacl for many days before it is safe for them to make this trip. Soon after leaving st. Michael the Rock Istand encounteled herary cross swells, the last trace of a gale that had disturbed Bering sea some days before. The little flat-bottomed steamer tossed about in a wonderful manner, smapping one of the hawsers which comnected her with a barge piled with hundreds of tons of heary freight. To properly secure the cumbersome barge was a serious task for our crew; however, by heading into the protected waters under a sheltered blufl this was successfully accomplished. About noon the swell died down and the rest of the trip through Bering Sea was made in smooth water. At 4 p. m. we anchored just north of Cape Romanof to wait until high tide before attempting to cross the shoals which bar the entrance to the mouth of the Yukon. At 6 o'clock on the following morning we entered the Aphoon mouth of the Yukon delta. The natives eompare the delta of the Yukon with its mouths to a human hand and have given the name Aphoon (thumb) to its northernmost channel.

What the Mississippi is to the eentral portion of the United States, the Yukon is to Maska. This great inland waterway, flowing through the heart of the rast northwestern section of the continent, has rendered it possible for the explorer to penetrate its remote fastnesses and make known to the world the untold wealth there held secret for unknown ages. The Lewes and Pelly rivers, which at Fort Solkirk unite to form the Yukon, have their sourees in the lakes held between the nountain langes of British Columbia, within to miles of the arms of the north Pacilic which penetrate southeastern Alaska. This Anazon of the north does not reach salt water until it has entered the Aretic Circle and turned southward to pour its muddy flood into Bering sea, more than 2,000 miles from its source. With its tributaries, it diains more than 600,000 square miles of territory and is said to discharge 
into Bering Sea one-third more water than does the Mississippi into the Gulf of Mexico. In its upper course it has sawn in twain the granite walls of the mountains which barred its progress; in its lower courses its rapid current undermines the muddy, forest-clad banks, sweeping along on its surface down to the sea the trees which it has overturned. When this driftwood reaches Bering Sea the great currents sweep it northward, distributing it along thousands of miles of treeless coast as far as Point Barrow, thus providing fuel and building material for many an Eskimo village. The mud which the Fukon deposits forms the treacherous bars and flats which extend into Bering Sea far out of sight of the low-lying land.

During the short season of navigation in midsummer the waters of the Yukon are plied by many large, flat-bottomed, well-equipped steamers carrving hundreds of passengers and thousands of tons of provisions and mining material for the busy settlements along the river and its tributaries. As the traveler is borne along, an ever varving panorama is unfolded before him. Along its vast reaches the banks of the river are covered with timber; here and there appears a treeless, grassy meadow, once the bottom of a lake which has been drained by the encroachment of the stream, now a favorite grazing ground for moose. In order to avoid the swift current in midstream, the steamer often hugs the shore near enough to hear the songs of the birds and to distinguish the flowers and moss that carpet the banks. In this land of paradoxes, while glaciers sleep between the mountains and snow rests on their summits, a luxuriant wealth of wild flowers colors the valleys at their feet. Toward the end of September the scene changes; before the chilly blasts of Autumn the birds fly to the southland, the prospector betakes himself to his cabin, the native to his hut, and in his retreat in the mountains the bear settles into his winter-long sleep. Soon every stream is locked in ice, every mountain is white from base to summit, snow lies deep above the withered flowers, and the great white silence broods over all.

From dawn until dark on August 8 we steamed through the Yukon delta, its low-lying, distant banks covered with willow and cottonwood and fringed with bleaching driftwood. Many sand banks projeeted from the muddy water. A few gulls that had strayed in from Bering Sea were the only signs of life. Early in the day we passed a flourishing settlement of natives who support themselves by eut ting wood and selling it to the river steamers. This was the first of a long series of wood camps which are found at frequent intervals all the way from the mouth of the Yukon to the head of navigation more than 2,000 miles above. The selling of wood to the steamers, employment as deck hands and as stevedores on the wharves, are industries which, together with packing supplies to the mines and selling dried 
fi has alog food in the winter, will support the thriftiest of the Yukon natives for many years to come. Each of the crew of stalwart native boys on our steamer received $\$ 60 \mathrm{per}$ month during the four months of naviration. Several of them expected to sceure amployment from trading companies and from army posts during the winter also.

At 1 a. m., August 9, we passed the mouth of the Andreafski River, $1 S 1$ miles from St. Michael. At this station many of the river steaners of the Northeru Commercial Company go into winter quarters. The small native village at Andreafsli does not at present contain a sufficiently large number of children to warant the establishing of a United ctates school at that place.

In a hary rainstorm, at 2 o'clock on the morning of August 10, we arrived at Hogmut (Russian Mission). At Ikogmut there is a Russian chureh, a trader's store, and a native village. A Luited States school was opened there last October. Here we landed Mr. Redmyer, who during the coming winter will transport a herd of reindeer from Bethel, on the Kuskokwim, to Copper Center, which is to be a new station for the reindeer industry. From Hkogmut Mr. Redmyer will follow the portage between the Yukon and the Kuskokwin, the first step in his long journey through the heart of the Alaskan wilderness. We left the party with their dogs and bales of supplies a forloru-looking group on the sodden shore, but Mr. Redmyer is an experienced explorer and was not daunted in the least by this somewhat inauspicious commeneement of the land part of his expedition.

On the river bank some miles above Russian Mission is a group of desolate cabins going to rack and ruin, a reminder of an unsuccessful attempt to carry the United States mail from this point to Katmai, on Shelikol Strait, 350 miles distant. Here the contractor with his ontfit was landed by the river steamer. The attempt to penetrate the fearfully rough, unexplored country to the southward proved too arduous an undertaking, and after suflering great hardship the contractor abandoned his project.

At Holy Cross Mission (Koserefsky) the results of successful mission work are more apparent than at any other point along the river. Here the Roman Catholic Church has maintained a mission since 1856. A range of hills shelters the group of mission buildings. On the level land hetween the mission buildings and the river are cultivated fields, where the painstaking missionaries and their native assistants have had great success in raising vegetables. Their vegetable garden, under the care of the native boys, in 1902, vielded 500 bushels of potatoes and 600 good solid heads of cabbage. Turnips, rutabagas, cress, and other rapilly-maturing vegetables grow in alum-

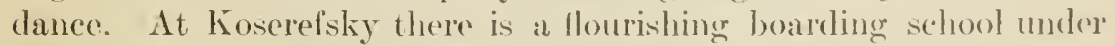
the charge of the Jesuit Fathers and another for the girls in charge of the Sisters of Saint Ann. The boys are instructed in carpentering, 
blacksmithing, gardening, and farm work; the girls, in cooking, household work, and needle work. The Bureau of Education assists in supporting the school by assuming the salaries of two teacher's, supplying the text-books needed, and paying for the fuel used in leating the schoolrooms. The school enrollnent during the term ending May 31, 1904, was 110. Father Luchesi, Brother Markham, and Brother O'Hare took pleasture in trying to give me an idea of the work, but I regret that I did not have time to make a satisfactory visit to the school. The Yukon cruise is a stupendous one, allowing only short stops at each place. After we had been on shore about half an hour vigorous blasts from the Rock Island's whistle hrought us hurrying on board.

The mission at Anvik, maintained by the Protestant Episcopal Church, was our next stop, on the morning of August 11. I had time for only a flying visit to the Rer. John IT. Chapman, Mrs. Chapman, and Miss Bertha M. Sabine, all reterans in the noble work of uplifting the natives of the Yukon Valley into Christian civilization and selfsupport. The school at Anvik does not yet receive aid from the Bureau of Education, but it is probable that assistance will be extended in the near future.

Nulato, where we arrived at 3 o'clock on the morning of August 13, is a point of considerable interest. It was the remotest trading station maintained on the Yukon River by the Russian-imerican Fur Company, the agency through which Russia held Russian Anerica until the transfer of the country to the Lnited States in $1 \& 67$. In the early days Nulato was the scene of considerable friction between the natives and the Russian traders. The natives resented the intrusion of the white men, and on several occasions destroved the improvements made during the summer by the Russians and abandoned by them during the winter. In 1851 Lieutenant Barnard, a member of the British expedition in search of Sir John Franklin, arrived at Nulato. In the course of his investigations he desired information from an influential chief; instead of requesting an audience with him, Lieutenant Barnard sent for the chief. This action the chief considered an indignity, and he determined to obtain satisfaction for the insult. At the head of a band of warriors the infuriated chief attacked the trading post, set fire to the adjoining native village, and shot with arrows the inhabitants who attempted to escape from their burning huts. Lieutenant Barnard and the Russian in command of the post were killed as they were rising from their beds to repel the assault. Lieutenant Barnard's grave is seen a short distance to the rear of the two or three dilapidated log buildings which are a reminder of the once flourishing post. In these days the Nulato natives are peaceful enough: many of them are members of the Roman Catholic Church, which maintains a mission in the village, and some of the 
most promising youmer men are apprentiess in the reindere herel which is under the eare of the mission. 'The Bureau of Education assists in bearing the expense of the sohool in eonnection with the mission.

On August 15 we reached the settlement on the north bank of the Yukon opposite the mouth of the Tamana River. As one approarches this important point the numerous buildings of Fort Gibbon, one of the largest army posts in Alaska, are seen: then follows a straggling row of log buildings alonge the edge of the blufl, flanked by the warehouses and stores of the North Ameriean 'Trading and 'Transportation Company and the Northern Commercial ('ompany. 'This small settlement has three names: Gibbon, Weare, and Tamana. Since the diseorery of gold in paring quantities on the crecks and tributaries of the Tanana and the establishment of the towns of Chena and Fairbanks, this settlement, at the junction of the 'Tamana and Yukon rivers, has becone an important point for the transferring of froight and passengers from the larger steamers to the smaller boats which with difliculty ascend the shallow, rapid, tortuous Tanana River. Hundreds of tons of freight and crowds of passengers are sometimes congested at this primitive settlement, which has absolutely no good accommodations for a large number of travelers.

During the evening of August 15 we left the wikle river and with difliculty threaded our way between the sand bars which block the entrance to the Tanana. The swift-flowing Tanana, with its driftladen eurrent and frequent sand bars, is a trial to the soul of the river captain who is compelled to push his long steanter and eumbersome freight barge around its abrupt curves. The Rock Island seemed to brace herself for the struggle, and panted and throbbed like a thing of life. Many a time her erew of native boys had to land and by pulling on a hawser swing the prow of the barge out of the swift eurent and around a sharp bend. By dint of hard work we reached the town of Chena, at the junction of the Tanana and Chena rivers, on the evening of August 20. On the way we passed the steamer Oil City, with a broken shalt, helplessly tied up to the bank. Her decks were black with miners and others flocking to Fairbanks, the most recent mining Mecca. We also left behind many small, flat-bottomed boats which men were laboriously poling against the swift current. The tewn of Chena is built on a plain, an excellent site for a town. but it is at present eclipsed by the larger settlement of Fairbanks, 12 miles up the Chena River. I railway from Chena to the gold-bearing creeks is projected. The town of Chena became incorporated in December, 1903. At the time of our visit it had a population of about 400. After making repairs to the machinery, the Roch Island proceeded up the Chena to Fairbanks. This short trip of 12 miles was the most difficult piece of navigation aceomplished since leavingr St. Michael. 
Fairbanks, the distributing point for the most recently discovered gold fields, almost in the center of Alaska, is on the Chena River, aloout 12 miles from its junction with the Tanana. The díscovery of gold in this district was made by Felix Pedro and others in 1898 , but it was not until the autumn of 1902 that the story of the rich strilie was told to the outside world. During the following winter many miners from (ircle City, Fortymile Creek, and Dawson, attracted by the tales of gold, flocked into the Tanana Valley orer the wiriter trails. The following summer the river steamers brought crowds of eager prospectors from the outside. Fairbanks has become the metropolis of central Alaska, and contains large warehouses and stores carrying ample stocks of prorisions, groceries, machinery, hardware, and miscellaneous merchandise adequate to supply all the requirements of the district. In sumner, steamboat service is maintained with St. Michael and Dawson. Conditions for mining are better here than in other sections of northern Alaska. Timber and water abound; on account of the comparatively mild climate the mining season is longer here than it is elsewhere; regetables are grown with great success, and prosperous truck farms are seen on the river banks as one approaches the town. About 5,000 persons have flocked into Fairbanks; they live in the log buildings of the town on the south bank of the river, or in tents in the suburbs on the north side. In the outskirts of the town is a large hospital, which was erected by Bishop P. T. Rowe, of the Protestant Episcopal Church. There are three saw mills in Fairbanks, and ther were kept busy both day and night in order to keep pace with the demand for lumber for the erection of the houses which must shelter the crowds of incoming people from the rigor's of the rapidly approaching aretic winter. Carpenters' wages at the time of our risit were $\$ 15$ per day.

On account of the heary freight charges on all commodities, living expenses are high. Flour cost $\$ 6$ per sack; beans, 15 cents per pound; beef, 50 cents per pound; chicken and turkey (cold storage), $\$ 1$ per pound; pork, 80 cents per pound; butter, $\$ 1.50$ per roll; hay, 7 cents per pound. In some quarters alarm was felt lest the few American steamers which ascend the shallow Tanana would not be able during the short time remaining before the river would be locked in ice to bring into the town supplies sufficient to feed the throngs that continued to pour into it. In order to provide an additional source of supply, by an arrangement between the customs officers of the United States and Canada, the steamers of the White Pass and Yukon Company and other Canadian steamers were given the privilege of cngaging in the Tanana trade until the close of the present season, provided that a convoy was put on board each steamer at Eagle. It is estimated that the output of the Fairbanks distriet will reach $\$ 1,500,000$ this scasous. 
Upon my return to the mouth of the Tanana, August 26 . I left the steamer Rock Island, which continued the royage down the river to St. Nichael. While awaiting the arrival of the Sarah, en route from St. Michael to Dawson, I was the guest of Maj. Arthur Williams, commanding officer at Fort Gibbon. It is a pleasure to arail myself of this opportuntiy to express my appreciation of the cordial hospitality extended to me by Major Williams and the other oflicers attached to the post.

During this stay I risited the St. James Mission, of the Episcopal (Church, on the river bank about 3 miles above Fort Gibhon. I regret that I did not meet the Rer. Jules L. Prerost, who is in chinge of this mission, but I had the pleasure of becoming acquainted with Mrs. Prevost and Miss Mason, who, among other duties, teaches the school. The mission station is an attractive group of buildings on the bluff overlooking the river. The settlement consists of a rery tasteful church, school, and residence building for the missionaries, and a neatly built native village of 40 or 50 houses. It is probable that in the near future the Bureau of Education will extend aid to this school.

In the village of Tanana I found an experienced teacher, Miss Emily B. Parke, whom I appointed to organize a school at Rampart, a mining settlement on the Yukon, 50 miles above Tanana. While I was delayed at Tanana the steamer Susie arrived. Among her passengers were Mr. and Mrs. D. W. Cram, who were on their way to Bettles, on the Koyukuk, at which remote point the Bureau of Education is starting a school, and whither during the winter of 1904-5 a herd of reindeer will be driven from the Bering Sea coast, thus forming a new center of the reindeer industry. At Tanana Mr. and Mrs. Cram awaited the arrival of the little steamer Koyukuk, which would carry them to their destination. They were in good spirits, and looked forward with enthusiasm to their pioneer work in that primitive region.

On September 1 I left my kind hosts at Fort Gibbon and went on board the steamer Sarah for transportation to Dawson. The Rock Island, on which I had made the first part of the river cruise, is one of the older, wood-burning steamers of the Northern Commercial Company, and several times a day we had to tie up to the bank and wait while the native crew carried many cords of wood from the bank to the steamer to feed the greedy fires with material to speed us on our way. These stops, however. frequently were interesting, affording opportunity to visit fishing camps and summer villages of the natives, or to wander over some flower-carpeted glade or wooded hillside. The Saruh, one of the largest and best equipped of the river steamers, is furnished with the latest vil-burning machinery, and stopped only at a few of the larger settlements just long s. Doc. $61,58-3-5$ 
enough to land freight and passengers, and then sped rapidly on her way.

Above the point where the Tanana enters the Yulion the seenery becomes bolder; the mountains approach the river, the banlis grow precipitous, and the steancr glides up a scries of canyons where the river has broken through the Rampart Nountains. 'The mountain sides covered with birch, willow, and cottonwood glowed with the rich tints of autumn, and their rugged summits were powdered with freshly fallen snow. The air was crisp and exhilarating, and all nature was bathed in brilliant sunshine.

During the afternoon of September 2 the Sarah tied up at Rampart, the distributing point for the Rampart mining district, a lypical Yukon River town. 'These little settlements along the river are few, and sometimes many hundreds of miles apart; they consist, for the most part, of the same elements. The largest and most conspicuous buildings, usually at the head of the wharf, are the store and warehouses of the trading company; a straggling row of $\log$ calins following the edge of the bluff are the homes of the miners, who, during the open season, live out on the gold-bearing ereeks, many miles distant from the village. The agent of the trading company, a United States commissioner, a postmaster, and perhaps a physician form the nucleus of the permanent population. Sometimes there is a group of mission buildings, church, school, and dormitories, where are found faithful, self-denying workers and clean, bright-looking native children, a contrast to the filthy, unkempt urchins l'rom the huts of the neighboring native village, with its howling dogs and accumulated filth.

Urgent requests had been received by the Bureau of Education for the opening of a school at Rampart. Miss Parke, the recently appointed teacher, left the steamer at this point and, with the assistance of the members of the school committee whose services were requested, we at once made arrangements lor the renting of a building for the use of a school until a permanent building could be erected. At $6 \mathrm{p} . \mathrm{m}$. the Sarah was again under way.

During the morning of September 4 we sighted the stockaded log buildings constituting Fort Yukon, a prominent place in the early history of the Hudson's Bay Company. This westemmost of the posts of the Hudson's Bay Company was founded in 1S47, and was the remotest point to which its indefatigable pioneers had penetrated. The present site was chosen in 1864. The older fort. was situated a mile higher up the river, but was abandoned on account of the encroachments of the stream, whose strong current had dangerously undermined the banks. Fort Yukon was supposed to be west of the international boundary line between Russian America and British Columbia, but its exact latitude and longitude 
had not been ascertained. The tratess of the Russian-1merican Fur Company, for the most part, confincel their operations to the settlements along the lowere raches of the Yukon, scolom asconding the liver beyond Nulato. Every spring the energetir Seotchinen of Fort Tukon were arenstomed to deserud the rivel about :300) miles to a point near its junction with the 'Tanana, where they mot the assembled Fudian tribes and purchased theil stores of hoar, marten, otter, mink, and fox skins before the tardy Russians from the lower livel, delayed by the swift current and masses of drifting ioce, could arrive at the rendezvous. The withdrawing of the RussianAmerican Fur Company after the transfer of the country to the Tnited States inameruated a new order of things. Several American companies established trading posts on the lower river, from one of which a small party sueceeded in ascending the river and wintered at a point opposite the Tanana River.

In the following spring, when the traders of the Iludson's Bay Company paid their ammual visit to their accustomed rendezvous, their right to trade within the temitory of the Enited States was fiercely contested. In the spring of 1869 San Franciseo capitalists proposed to transport to St. Michael on the deck of a sailing vessel a small steamer which would ascend as far as Fort Yukon, trading with the tribes along the banks. These movements rendered it extremely desirable that the position of Fort Yulion should be officially determined, and oceasioned the first action on the part of the Cnited States to ascertain something of the interior of the vast region recently purchased from Russia. During the summer of 1869 , by direction of the Secretary of War, Capt. Charles P. Raymond, of the Engineer Corps, ascended the Yukon River to Fort Yukon to determine whether it was in the domain of Great Britain or was included in the district of Alaska. Fort Yukon was foumd to be within the territory of the United States, and it was subsequently abandoned by the British company.

In October, 1904, the Buxeau of Education established a school at Fort Yukon to provide school lacilities for the children of the large tribe of natives who spend most of the year in this vicinity. From the Rampart Mountains to Circle City, a distance of between 300 and 400 miles, the river traverses the level stretches known as the Yukon Flats. Innumerable islands intersect the wide, shallow chamnel; comtless sand hars and mud flats, blind sloughs, and shifting shoals lorm a perfect maze. Four feet draft is perilous; anything beyond that makes promess impossible. It some remote period this region was the bottom of a great lake, of which the Rampart Mountains lormed the western barrier. Into this lake the Porcupine, Birch, and smaller streams emptied their sodiment. After the river had cut its way through the Rampart Mountains, 
thus draining the lake, the enormous quantity of silt deposited by these streams remained as the flats of to-day. Many river steamers have come to grief on these shoals: high and dry on a sand bar, the rictims of merciless mosquitoes, impatient passengers frequently spend many days of monotonous delay; here and there are the timbers of some wrecked steamer left to bleach eternally under the scorching sun of midsummer and the fierce blasts of winter.

In remote ages this region must have been the labitat of large numbers of mammoths; their huge bones, tusks, and teeth are found in great abundance in the flats and the adjacent country.

On the plateau forming the eastern boundary of the Yukon Flats lies Cirele City, once the metropolis of the Yukon Valley. Before the discovery of gold in the Klondike region of British Columbia, gold had been found in paying quantities on Birch Creek and other streams wholly within the territory of the United States, and Circle City was the result of the stampede that followed these discoveries. On this plateau, orerlooking the river, almost under the Arctic Circle, was built the largest town of $\log$ buildings in the world. Thousands of miners, many of them having brought their families with them, wintered here. In order to beguile the tedium of the long winter, the exiled people introduced into this northern wilderness many of the refinements of eivilization; conspicuous among these was a wonderfully well-selected library of several thousand rolumes. The stampede to the Klondike depopulated the town; the public sehool that the Bureau of Education had established hat to be closed on account of lack of pupils; the fine library found shelter in one of the buildings of the Episcopal Mission; the windows of the cabins were boarded up, the doors securely fastened, and Circle City became a silent, almost deserted eity. Since that time Circle City has been filled up sereral times only to be emptied out again when new grold strikes wore made. Its hundreds of empty log cabins form a picture of desolation. Several of the cabins which have been deserted by the white men are now occupied by natives who have moved into them from their camps on the neighboring streams. Conspicuous on the edge of the bluff orerlooking the Yukon are the buildings of the mission which the Episcopal Church maintains at this place. The Bureau of Edueation will probably assume the salary of the teacher and the supplying of text-books for this sehool.

Circle City is now the starting point for the winter trail from the upper Yukon across the country to the Fairbanks district.

At the mouth of Miller Creek is the town of Eagle, the last of the settlements on the American side of the international boundary line between Mlaska and British Columbia. It is the point of supply for the diggings on Miller Creek, Seventy-Mile (reek, and other streams. 
The United States custom-house and the army post. Fort Exylert, make Eagle an important point. It is an incorporated town and manages its own school aflairs. The spiritual and educational needs of the natives in the neighboring village are cared for by the missionaries of the Episcopal Church. Aid to this school also will in all probability be extended by the Burean of Education. From this point it is hoped to reach with school privileges the Ketchumstocks. a tribe inhabiting the interior country near the sources of copper River. At Eagle, about midnight September 6. I met and consulted with Mr. F. E. Willard, who was on his way to take charge of a public school at Fort Yukon. The steaner Lavelle Young, on which he was a passenger, was densely crowded with men and women eager to reach Fairbanks before the closing of the river by ice. In every available place temporary bunks had been constructed and eren these were not nearly sufficient to accommodate the crowd. The floor of the dining saloon was corered with sleeping forms, each wrapped in its blanket, and it was almost impossible to take a step without stirring up some human chrysalis.

Early on the morning of September 7 we crossed the international boundary line and entered British Columbia. A long, straight path 6 feet wide cut through the timber on the mountain side renders the course of the hunched and forty-first meridian very distinct.

Dawson, 1.600 miles from St. Michael by river, is the terminus of the American river steamers. It is the metropolis of the famous Klondike district. The motley aggregation of tents and log cabins of the days of the Klondike rush lias become a great commercial center with all the conveniences of a modern city-good hotels, schools, churches, hospitals, waterworks, telephone service, fire department. newspapers which daily publish telegraphic dispatches from all over the world, stores and warehouses filled with groceries, dry goods, hardware, machinery, and household goods of every description. Since $1 \mathrm{~s} 9 \mathrm{~S}$ the amual output of gold from the creeks that empty into the Klondike River, a tributary that enters the Yukon through the suburbs of Dawson, has averaged more than $\$ 15,000,000$. The tide of travel which eblos and flows through Dawson is ronsiderable. The records show that during the ten months commeneing December, 1903, 4.17- persons arrived at Dawson and 6,5s1 left. At an arerage of $\$ 100$ per ticket, the fares from this travel would aggrecate more than $\$ 1.000 .000$.

The schools of Dawson are remarkably fine. The gorermment provides generously for their support: liberal salaries are paid to the teachers, and thus the service of thoronghly eflicient people are secured; the schoolrooms are attractive and furnished with 
modern apparatus. The wistom of providing thus liberally for the schools can not be too highly commended.

During the season of open narigation the steamers of the White Pass and Yukon Company ply on the rivers and lakes between Dawson and White Horse, at the foot of White Horse Rapids, the limit of river travel and the northern terminus of the White Pass and Yukon Railway, which connects the interior country with Skagway on the coast. In winter a 4-horse stage line is maintained between Dawson and White Horse. Each sleigh is provided with an ample supply of fur robes and has accommodations for 10 passengers, 1,000 pounds of baggage, and 1,000 pounds of freight. Relay stations are maintained every 20 or 25 miles, at which fresh horses are furnished. Passengers travel during the daytime only, stopping overnight at well-appointed road houses along the route. Heretofore the line of winter travel for a long distance followed the tortuous, ice-bound surface of the river and was interrupted during several weeks in the autumn while the ice was forming and in the spring during the breaking up of the ice. Recently the Canadian government has completed a direct overland road from White Horse to Dawson. The distance between White Horse and Dawson by this route is 327 miles, and the average time between these places is from five to five and one-half days. In summer the arerage time from White Horse to Dawson by steamer is from thirty-two to forty hours, and the average through time from Seattle to Dawson, from five to six days.

I left Dawson for White Horse on the White Pass and Yukon steamer Sellirl: September 9.

In its upper courses the Yukon River is a very different stream from the wide, drift-laden flood that sweeps down to the sea between the low-lying, forest-clad banks of the delta. For the most part it is a narrow, swift, winding stream hemmed in between bare walls of granite or basalt. The hills are seldom at a great distance from the river. Even the color of the water had changed; the brown, mud-laden flood had given place to waters of a grarish hue, thick with the volcanic ashes which the White River, draining a voleanie region, liad poured into the main stream. For miles the steep, sandy bankis are honeycombed by thousands of nests of martins, which breed in this north land during the short summer. These upper stretches of the river mark the limit of the salmon's long travels from the sea. Ip the river, over shoals and battling their way against rapids, these beautiful fish travel in pairs, until here, thousands of miles from salt water, their strength sapped by the long journey, the salmon deposit and fertilize the spawn. The parent fish then die, having fulfilled their mission. Their carcasses furnish the favorite food of the bears. During the autumn months, through a field glass, the sluggish bears which have come down to the 
riverside from their homes in the mountains frequently nuay be seen feasting on the hundreds of dead salmon lying on the sambly shore.

This part of the river is famous in the ammals of the Iludenn's Bay Company, the powerful wedge with which British civilization cleft its way from ocean to ocean. Fort Selkirk, near the junction of the Lewes and Pelly rivers, is a reminder of those early days. This pioneer post planted in the northern wilderness wat the seene of frequent hostilities between British traders and barbarous natives. In 1851 the Chilkats. one of the coast tribes of southeast. Alaska, instigated perhaps by the jealous Russians, appeared hefore Fort Selkirk in force. Resistance on the part of the factor of the Hudson's Bay Company and his two assistants was useless. The natives entered the stockade, bound the white mien, plundered the storehouses, and wantonly destroyed hundreds of dollars worth of valuable goods, which it had taken many months of incessant lahor to bring into that remotest outpost. Then they departed, after setting fire to the fort. Two blackened chimneys are all that remain of old Fort Selkirk.

In later days Fort Selkirk has been the center from which Bishop Bompas, of the Episcopal Church, has spread Christian cirilization among the natives of that region.

At 5.30, September 13, the steamer Sellirh arrived at the town of White Horse, 2,200 miles from St. Michael, the head of river narigation, a short distance below the White Horse Rapids, which form an impassable barrier to the further progress of the river steamers. From White Horse there is one passenger train a day to Skagway. It had left before the Selkirk arrived and we spent the night in White Horse. The large warehouses along the river front contained thousands of tons of freight for the interior which had accumulated at this point, and it seemed doubtful if all of it could be carried to Dawson by the steamers before the elosing of the river by ice.

The White Pass and Yukon Railway, between skagway and White Horse, 112 miles in length, was the first railroad built in the Far North. The work of construction was commenced in June, 1S98. by a syndicate of British eapitalists to afford aceess to the gold fickds of the Klondike region. From its starting point at skagway, the railway follows the trail over the White Pass, the route taken by thousands of miners in the days of the Kilondike stampede. 'The successful construction of this railway in that ligh latitude. thounands of miles from its base of supply in the States, was a great foat of engineering.

Before the work commencel, the careasses of more than two thousand horses which were seattered along the line of the niners' trail were collected and burned with kerosene. For miles the roadbed had 
to be cut in the face of the solid rock by men lowered into position and supported by ropes; steel bridges had to be built over roaring torrents and deep gulches; almost insuperable diffieulties of grade had to be overeome; in attempting to lower Lake St. Louis 3 feet, the entire lake washed away causing widespread damage. The railroad was completed in June, 1900. It is stated that the cost of constructing certain sections of the road exceeded $\$ 250,000$ per mile. Its total cost was about $\$ 5,000,000$. The traffic of the road has been so great that it paid nearly $\$ 2,000,000$ profits during the first two years of its operation and it continues to pay inereasingly large dividends. Snowsheds and snowplows keep the line open during the winter, and traffie is rarely interrupted by the tremendous storms of that high latitude.

The passage from salt water to the head of river navigation formerly involved weeks of incessant toil of the sererest description: packing supplies over steep mountain passes; clambering over huge bowlders; wading across swift, ice-cold torrents; shooting seething rapids; fighting millions of gnats and mosquitoes; sleeping on the damp ground above the eternally trozen subsoil wherever overtaken by the darkness of night. Now, in a comfortable, well-equipped train, the passenger is whirled along beside the shores of the lakes, orer gorges and across rivers; from the observation car he gazes upon the magnificent scenery that meets the eye at every turn, and reaches his destination in a few hours, refreshed and delighted.

At Skagway, on the evening of September 14, I took passage on the steamer Cottage City, arriving at Juneau at 3 o'clock on the following morning, Both Skagway and Juneau are incorporated towns which manage their own school affairs; accordingly, I did not linger in either of them.

I was fortunate enough to find the U. S. S. Rush at anchor off the town of Juneau. On September 15, by the courtesy of Captain Kilgore, I went on board that ressel for passage to Sitka, where we arrived on the 17 th.

During my stay in Sitka I repeatedly risited the three public schools and consulted with Hon. John G. Brady and Mr. Edward de Groff, the president and secretary of the local school committee for Sitka.

On September 29, I left Sitka on the steamer Georgia, making connection at Juneau on the following day with the steamer City of Seattle, for Seattle, where I arrived on Oetober 4.

Having completed my business with the firms in Seattle and San Franciseo, who had furnished the season's supplies for our work in arctic Alaska, I left San Franciseo on October 12, arriving at Washington five days later, completing a tour of inspection which had covered about 14,500 miles.

I desire to express my appreciation of the numerous courtesies received from Capt. Osear C. Hamlet, commanding the U.S.S. Thetis, 
INTRODICTION OF DOMEATIC REINDEER INTO ALASKA. . 53

from Capt. W. F. Filgore, commanding the UT. S. S. Rush, and from the officers attached to those ressels.

I have the honor to be. very respectfully,

\section{Millam Hamintox.}

Hon. W. T. HLkRis, Assistant agent of Éducation in Alastir.

Commissioner of Education.

(Through Sheldon Jackson, general agent of edueation in Alaska.)

\section{ANNUAL REPORT, NLLATO REINDEER STATION.}

Netato, Alaska, October $\%, 1904$.

DeAr SIR: Inelosed please find the ammual report of the Nulato reindeer station, for the year 1903-4. I inspected the herd during the latter days of September and found the deer in very good condition. Ther are loeated at the foot of Hotel Mountain or Hodo'ore, one of the higher summits of the Kayar range, about 25 miles southwest of Nulato. We expect to bring back the herd to its former winter quarters 2 miles below Nulato, toward the end of November, but the reindeer moss there available will hardly last over two months, so we contemplate moving them again in February to some better pasture in the Karar region.

The herder actually in charge. Per Nilson Bals, has renewed the contract for one year, under the same conditions as before, and three copies of the agreement, which he and I signed, will be sent to Unalakleet by next mail.

Statistical report, reindeer herd, Nulato, 190.4.

Name of owner, Mission.

Old deer and fawns of 1903 :

Male ... . . . . . . . . .

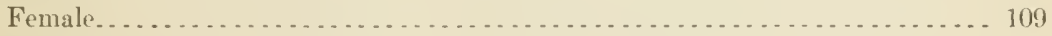

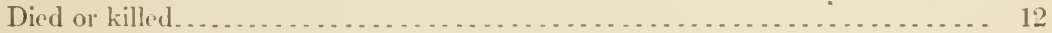

Fawns born, 1904:

Male . . . . . . . . . . . . . . . . . . . . . . . . . . .

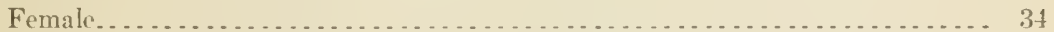

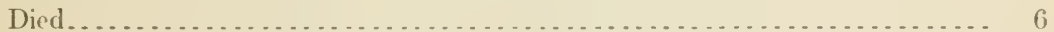

Total fawns living. . . . . . . . . . . . . . . . . . 66

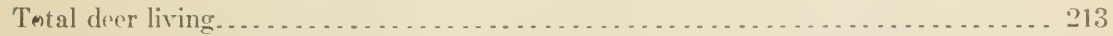

Apprentices, 1903-1.-Nexander Kinliana Dimoska, August 15, 1903, to February 15, 1904, six months; Mareh 15 to June 1, 1904, two and one-half months. Martial Ketsegeyak, May 1 to Oetoher 1 . 1904, five months. Roger Kedelor, February to March 15, 1904, one month; June 1 to August 2s, 1904, three months; October 1, 1904. Neduruslet, April 1 to April 30, 1904, one month.

Respeetfully, yours,

Dr. Sheldox Jackson,

JuLiUs JeTti, $S . j$.

Washington, I). $\mathrm{C}$. 
EXTRACTS FROM THE DAHLY JOURNAL KEPT ON THE JOURNEY FROM UNALAKLEET TO BETHEL AND RETLRN, IN NOVEMBER AND DECEMBER, 1903.

By C. O. Lind, M. D., General Superintendent Central Division.

The first week of November, 1903, has been a real busy one at the reindeer station at Unalakleet. Nils Bals and myself have had our hands full in repairing of sleds, harnesses, tent, ete., for the long and difficult journey we are just ready to begin. A young Lapp, by name Per Sara - a son to Nils Sara, whom we are about to move from Andreafski, on the Yukon, to Bethel, Kuskokwim-has been helping us a little with the preparatory work for the privilege of going along to meet his parents. The Sara family was broken up in Norway the winter of 1898 . Father and mother departed then from their native land, taking the smaller children along with them to Alaska, but leaving some of the older boys behind on the European soil. Per Sara is one of said boys, who had just arrived from Lapland a couple of months earlier to rejoin his parents and other members of the family in far-off Alaska. He could speak neither English nor Norwegian. Nallogoroak - the straight one-a native herder at Cnalakleet, who also is to join the party for Kuskokwim, has been busy at the herd the last few dars. He came down to the village in time for an early start on Saturday morning, November 7 . Sleds loaded and all ready; the 4 deer from the Mission herd were here also, but 3 more deer which were to be brought down from Ole Bahr's herd failed to come until late in the aftermoon the same day. Naturally we would not begin our journey late Saturday evening, so it was deeided to wait until Monday morning, November 9.

Monday morning found Nallogoroak, Per Sara, Nils Bals, and myself, with 7 deer and as many sleds, with provision, tent, necessary elothing for the trip, all ready. Farewell was taken on the ice near the mouth of Unalakleet River. Almost the whole village population was there to say good-bye. Mrs. Bals and Mrs. Lind followed us about a mile farther, and then a final farewell was taken, and the real travel had begun.

The day has been a beantiful one; clear, bright sky, with a southwesterly wind which was quite cold. Haring traveled about 18 or 20 miles till 3.30 p. m., we were foreed to retrace our steps 3 or 4 miles to a creek just passed, the reason being that the mountains come right to the water's edge and hhere terminate with an almost perpendieular wall, leaving no beach at all. The surf had piled the ice in big hummoeks, over which it was impossible to travel, and outside of these the ice was not safe, so the best thing and the only thing was to go back to the nearest place where it was possible to gain an access to the tundra. This we did, and reaching the place darkness overtook us; so our first camp was made. Due to the fact that we 


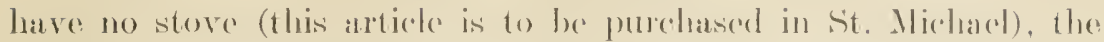
herelers felt disinclined to put up the tent overnight. The whole camp (consists of a houfire, around which we sit making cofleo and are trving to thaw out our hread and butter which is to sorve for supper. It is dark and eloudy this crening. The wind is increasiner in strength and velocity. Ifter supper and evening prayer we all went into slecping hage among somo small willows near the ereck.

Tuesday, Nomember 10. The rough road of yesterday had been rather severe on two of our sleek, so before starting out this morning they had to he repaired. It S o "elock we started off over the almost smowless tumdra. Our progress was of necessity very slow, having to cross at least hall a dozen little creeks on our way, filled with willow bushes which had to be eut down to allow of passing. At 12 uoon we arrived at Galsovia, a small native village, about 30 miles from Lnalakleet, where we stopped for a eup of tea. In the afternoon wa had a better trail along the shore and could travel better. Camp was made at 4.30 p. $m$. On the beach abont 10 miles larther south. Nallogoroak and I made the eamp while Bals and Sara went off to stake the derer. Unfortunately no moss was to be found for sereral mites, it all being burnt. The wind is blowing hard to-night and it is snowing some. It is only by repeated pounding of my hands that I can hold the pencil while writing these lines. At \& o'clock we all retire in the tent to-night.

Wednesday, Torember 11.- The moming hours passed by umusually fast to-day, not because we were more tardy than usual, lut because of disadvantages for which we are not lesponsible. Mr. Bals went out in search of better feeding ground for the deer at $4.30 \mathrm{a} . \mathrm{m}$. Fortunately he found a small patch of moss which had not been destroyed by fire, where he left the deer while he himself returned for breakfast, which was readr and waiting. After our morning meal Nallogoroak and Sara went to bring the deer, Bals was investigating the strength of the ice and pioking the way, while I loaded the sleds and made everything in readiness at camp. It was 10 o'clock before Bals returned and we could go onward. Our way over the new ice was certainly not without risk, but should we have followed the tundra it would have taken probaloly all day to make the next villacere, Thickotawik, which we now reached at $12.30 \mathrm{p}$. m. There we stopped for coffee and lumch about an hour and a half. 'The weather being l'athor thereatening, Mrr. Bals did not feel like going any farther; but 1 pursued a diflerent line of reasoning, thinking that if a storm should set in soon wo had better go on as far as possible and gret to Si. Michaed, where wowould not be so dependent on the goiner or coming of the jee. So onward we went about 10 miles nore during the afternoon, to Wood Point, where wo arrived at 4 p). m. and made (am p) for the night. It is cold to-night. I strong westerly wind is blow- 
ing, penetrating anything and everything in its way. We are all gathered around a big fire on the beach while eating our supper. One side is actually getting stiff from cold while the other is roasting. The clouds have disappeared and it is a starlight, beautiful evening. We all retire to our sleeping bags at 7 o'clock.

Thursday. November 1.2.- Immediately after we had retired last night steps of a man were heard outside the tent, and the next moment a roice asked in Eskimo, "Tho is here?" As no one answered tle inquiry, another question followed in English. "What kind of a place is this!" I told the man at once who we were and what we were, and asked him, if he had any dogs to tie them up immediately, because our reindeer were feeding in near proximity to the tent. "I have dogs, but they are all tied," answered the man. However, not trusting what the man said, I asked my three men at once to arm themselves with guns and run for the place where the deer were. Meanwhile I went out to the stranger, who stood just outside the tent trying to tie one of his dogs, while the rest were running loose in the bushes. One dog was already missing, and all the deer were gone and could not be found anywhere. Finally, about 10 p. m., the herders returned from the mountains, fortunately having found the deer, all in apparently good condition. But the missing dog not being found, we dare not leare the deer and so decided on taking turns to wateh all night. Armed with my shotgun, I took the first turn for two or three hours. Luckily no one else needed to take any turn, beeause before the termination of the first hour the dog was found. Our stranger then started off for his sled, which was left some distance off on the ice. To see that he really got away with his dogs I followed to find the sled. Owing to the many hummocks on the ice, it took us a long while to find it, in fact so long that I began to doubt the integrity of the man's statement. On my return to camp, about midnight, the moon just rolled over the mountains in the east and gave a bright light on my lonely path. In camp all had gone to dreamland, and none heard me join their band that early hour of 1 o'clock.

The day has been a beautiful one, with a light westerly wind. Due to the disturbances of last night, we did not leare eamp until 9 a.m. At noon we arrived directly opposite St. Michael, on the south side of St. Michael Bay. Mrr. Bals and I walked into the village to buy a stove and some other things needed for the trip, while Sara and Nallogereak continued about 3 miles farther to make camp and wait for our return in the evening.

After having had a little lunch we proceeded to business, but a stove which was fit for the journey could not be had until the next morning. Capt. C. Y. Malmquist, the Northern Commereial Company's agent, invited us for the night and treated us most royally. 
Bals returned early, but I sat up until about 10 p. m., engauged in writing letter's to the dear ones at home.

Friday, November 13.- About 9 o'clock this morning I got the stove, shells, and cartridges that we wanted. It 11.30 wo were all gathered again in our camp. The two men there were well, and so were the deer. A quick luncheon was taken, and half an hour later the sleds were packed, deer harnessed, and off we went in a southerly direction along St. Michael Canal. In all we traveled about 15 miles during the afternoon, and to-night we are more cozily fixed than usual. Our tent is placed in a bunch of bushes near a little creek. We have a nice stove in it, and can now keep both the food and ourselves warm and comfortable while eating. Another thing which gives us great comfort is the fact that we are now so far away from human habitation that we are not apt to be bothered by logs any more. The snow is deeper south of St. Michael, making the uneren tundra better adapted for traveling.

Saturday, November 14.-God in His merey has given us another most glorious day. The sun has been as bright as it is possible for it to be so far north at this time of the year. We left camp at the hour of $\&$ this morning and traveled in a southerly direction all day until $3.45 \mathrm{p}$. m., when we again made camp, this time at a point exactly opposite Cape Romanoff and about midway between said cape to the right and the mountain range on the left. Our tent, like last night, is placed among some small willows in a little creek. The distance from our last camp I judge to be about 20 or 21 miles. The snow is deeper for almost every mile we travel southward. Still, as yet there has not been enough to hinder our progress. An easterly wind has blown all day, and to-night it is very cold, but we are comfortable in our tent with the stove. I sad accident happened to-day when coming down some steep hills. The sleds rolled over and our storepipes were knocked apart, and it was nearly impossible for us to repair the damage with the means at our disposal. Supper is orer and the dishes are washed, so we are ready to retire about $S$ o'clock.

Sunday. November 15.-Another most beautiful day. When the herald of the day majestically appeared on the mountain tops in the southeast we had already breakfasted. loaded our sleds, and the caravan was slowly but surely adrancing orer the desert of snow. The same southerly course has been kept to-day, and this erening we are about 20 or 22-2 miles nearer our destination. True, wo can not compete with the Overland Flyer, nor any other flyer, but we are moving steadily onward. Toward evening a strong northerly wind started to blow, stirring up the snow considerably. As our company was not in sight of any place suitable for camping, we hacl to move onward for about thirty-five or forty minutes, until finally 
a little creck was reached in which some willows grew. It was certainly not a farorable camping place, because not a stick of dry wood could be found anywhere; but fortunately we arried some sticks of dry wood on our sleds by which to start the fire, and then we dry the willows about as fast as they burn. In thought of to-morrow, we have tried to dry some sticks in advance, but it secms ahmost hopeless. Still we are happy, and thankful for the shelter the tents afford us. After having walked a whole day over the uneven tundra, in $S$ or 10 inches of snow, it seems like a paradise in the tent Hu! how the wind is howling outside to-night, and how it tears and tugs at the place of our habitation. Soon, however, we will all be in our bags and then the wind will bother us very little. Mr. Bals has already turned in, and is snoring away as if he were going to Kuskokwim in a single night.

Uonday, November 16.- The day has not been so full of favors as the sixteenths have generally been to me. Somehow things have been a little contrary to-day; but we can not always sail in fair winds. Due to the fact of our less suitable camp of last night, we finished our duties late. During a stormy night, with flopping of the tent and rattling of the store pipes, etc., the night's rest was greatly disturbed.

At 4 a. $m$. I was up to see what kind of weather it was, but it being very dark and cloudy, I again crept into my sack and slept soundly until 7 o'clock, and no one else woke before being called. Having to contend with poor wood, it took a long time to get breakfast ready, so before we got away from camp it was about 9 o'clock. The wind was raging and the snow flying so that we could see but a short distance ahead. Our course has been a little to the east of south, along the foot of the mountains to the left, while the Yukon flats, we know, are to the right. Were it not for the hills, it would be impossible to travel at all on a day of this kind. Several times had we to stop and cut our way through brush in small creeks which were of necessity to be crossed. No one had a desire to stop for lunch to-day. All were anxiously struggling along, expecting to arrive soon at a river valley, where, according to information, a good camping place was to be had. About 4 p. m. we arrived at the expected place, hungry and tired from the day's struggrles. Truly this is a good place. We had plenty of wood and water and good shelter from the raging wind. Indeed it is so comfortable here that I much foar we shall not be able to get away to-morrow. The wind has been a little south of east and continues the same to-night. Nunapikloak (plenty crooked) is the name of the river on which we are camped to-night, and only about 10 miles away from where we were last night.

Tuesday, November 17.-Another day which has not been what 
one would call a perfect success. (Our last camip was really so good that it took us a long time to get away from it. 'Then having gone only a short distance this forenoon, Nallogorouk went astray after some ptarmigan, and after a while the whole party was delayed over half an hour waiting for him; but when he finally came, he brotglit four birds. Nbout noon Bals and I stopped to make tea, and had it all ready when Sara and Nallogoroak came, again having been after birds. This time Nallogoroak had shot three more birds, which were added to our stores. Sara had broken his sled, which accident took us fully an hour to repair; and on account of it we were not able to get to the good camping place of which we had previously thought. Darkness came on, and forced us to stay among some small willow bushes, on the open tundra. The wind has blown hard all day, but the weather has been, and still is, clear. One thing that bothers us exceedingly much to-night is the stove pipes. Because of the constant flopping of the tent, they jerk oll so often that it is all one man ean do to just stand and hold them in place, while I try to prepare the ptarmigan for supper. The distance traveled is only about 16 miles.

Wednesday. Normber 18.- The morning of the day was rather dark and threatening in whatever direction one could look. The heary wind that had been blowing from the south the last few days had brought mild weather, and the snow, to our great disappointment and hindrance, had almost entirely disappeared during the night. Fortunately, we had only 5 or 6 miles to the portage at the head of Pastolik River, where we were to change our course to the east, in order to gain entrance to the portion of the country drained by the Clear River.

Wo left camp at 7 a. m., and at 11 a. 11 . we had finally toiled over the mossy nigger heads and reached the summit of the divide. 'To our great help and happiness, there was more snow on the east side of the mountains. The afternoon has been more in our faror, so we have been able to make up partly for the unfarorable morning hours. After crossing the divide our course has been winding along in a similar manner to the creeks. On a little divide between two small tributaries to the Clear we are confortably camped this evening. This is a well-sheltered place, with plenty of dry wood. Te arrived here at 4 p.m., and have supper over at the early hour of 6 o'clock. Being nice and warm, it would be a pleasure to sit up for' a while chatting, but as we do not understand each other, but to a very limited degree. I find it more profitable to turn into the sleeping hag and prepare for an early start to-morrow.

Thursday, Nowember 1.9. - Surely we had an early start this morning. Breakfast was over at 60 clock and half an hour later we were trudging up a big mountain, winding along the course of a creck. It has 
been one of the most beautiful days a person could wish to see. It has been clear and cold, but not too cold, just right to make it agreeable to travel. No wind of any kind has been felt all day. Again we have suffered for want of snow. The hills are practically bare. About 2 o'clock this afternoon from the top of the mountain we could see the hills $s$ miles west of Clear. According to Mr. Bals's statement, we should ret be fully 25 miles away from the village. I am very tired and sore all over my body this evening, from that constant slipping from off every "nigger head " that happens to be in one's way. It is really a wonderful thing that one does not break off arms and legs at the "roll overs" one makes over these stumbling blocks in the way of every step.

Friday, November 20.-Before 7 a. m., our little caravan was moving along over hills and valleys, and at 3 p. m. camp was made about 5 miles west of Andreafski. When comfortably located for the night, with hand bag and my medicine bag on back. I started for the village to find Spein and Sara, whose herd and families we eame purposely to move. Bals had instructions to come after them in the morning in company with the other two men. If Spein and Sara had carried out their instructions and gone up the Yukon at freeze up (for us to follow until they were reached), this would have been just the proper procedure. Howerer, as soon as we arrived, I was met with the unpleasant news that they had not yet left their last summer's camp. The consequence of this simply means several days delay. Now we have to go back up the Andreafski River about 12 miles, and then from there start anew.

I was rery hospitably received by Mr. and Mrs. Petre-the Northern Commercial Company's people and given a good supper and a warm bed. The day has been most beautiful but quite chilly.

Saturday, Norember 21.- - After breakfast Mr. Petre accompanied me out in the village to see the sick people. One case of serere type was found and several cases with minor ailments, for which medicines and advice were given. At 11 o'clock a. m., Bals, Nallogoroak, and Sara, jr., arrived with the deer. At once we proceeded to take an inventory of our provisions and to lay off stores for the return trip. Three dars ago we had the misfortune to break our coffee kettle when rolling about in the hills, so we had to buy a new one, together with some extra strong storepipes. Because of the little snow the sleds roll over almost every rock and knoll and we do not know what moment our most essential articles of outfit may get damaged or probably ruined. Purchases made, lunch taken, and provisions stored, the time had already advanced to 1 p. m.. when we started in search of the herd and herders camp. The whole day had been dark and snowy, but toward evening it became far worse. It grew so thick in fact, that we could not find the herder camp, although I knew 
exactly where it ought to he. Weseareled lor it in rain until nearly j y. m., when it became su dark and stormy that it was hard to malkr

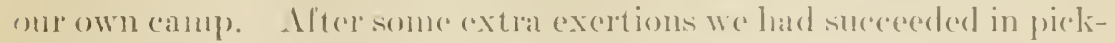

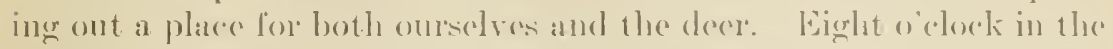
evening, and thewind is still howling and shaking the bushes violently, but we have a perferet shelter. It concerus us very little mow what weather and wind there nay be mutil the morning, when the hunt for the herders is to begin ancw.

Sunday, November 22. - Last night was pouecoful, and at daylight, so'rlock, we were all out on snowslocs in erery dinetion looking for tracks of deer and people. Breause of yesterelay's snowstorm all scarching seemed to be marle in vain. I went to the plare where the herders had their camp last fall and where they were said to be now. The place was foumel without difficulty. but they wore there no more. Wre had been to the rery spot last night, but could not recognize the place now since the (amp was noved. The four of us recomnoitered the comutry in different directions all forenoon in scarch of the new camp, but it was to be found nowhere. In the afternoon we started off for Andreafski again, searehing as we went along. And this crening we are again camped a short distance awa y from the village. During our return some tracks were found on the river at one place, which seemed to indicate that the herd had been driven towarl the Yukon. Thinking over our conversation with Mr. Petre about the herders we are inclined to think that he might have mismolerstood the Lapps--who all speak English very poorly, or not at all - and so misdirected us. Instead of their being on the main Andreafsti River we might be entitled to the belief that they are now 12 or 11 miles up the main Yukon, because that would comespond with the instruetions that the Lapps already had. To-morrow morning, if the weather permits, we ale going up the Yukou said distance, to see if any trace can be found of the lost ones. The day has heen cloudy with a northeasterly wind. No snow has fallen and it is rery mild weather, almost thawing.

Monday, November 2.-Dreakfast was over at. j.30 o'clock, and a little after 6 o'clock we were on our way toward the rilkage of Andreafski once more, to investigate il the hed and Lapps vere not up the Yukon. Upon our arival most al the people were yot asleep. Fortunately some natives had just come down the river some 20 miles. but they had no knowledge concerning the sought ones. From such information our minds were naturally undecided again as to the programme for the day. Bals thought it better togo homeagain, lunt, of course, such an act eould not be done. The herd must he lommel.

In a few mimutes the whole villater was astir herause of the presence of reindeer. Some of the natives at home in Indreafski declared that they knew where the lapps had their camp. Picking out the one

S. Doc. $61,5 \mathrm{~s}-3-6$ 
native who seemed the brightest, and paying him s.2, he followed to show us the place. We had, howerer, not gone many miles before we found that he led us to the same place we had been to previously several times. It would be of no use to go there again, so having gone about 9 miles, we stopped. It was about 11 o'clock. Nils Bals and the Andreafski native made an exemrsion ofl among the hills to the sonthwest to see if the herd was driven across the Yukon to the west of Andreatski. Nallogoroak watched the deer and made tea while Per Sara and myself went in a northeasterly direction to the hills on that side of the Andreafski River, a distance of about 3 miles. The whole distance was searched most carefully, but not a sign of a human being was seen anywhere, nor that of a decr.

Having arrived at the foot of the hills wo followed them first in an easterly direction about a quarter of a mile, and finding that way practically impossible for either man or beast we returned and went northwesterly along the hills, and after having plodded through loose snow, knee-deep, for about a mile, I saw something that looked like an old track of a man. Although old and snowed over it was a source of encouragement. With lighter steps and hearts beating with hope we eontinued through brush and snow a couple of miles when suddenly one of my feet was caught in a ptarmigan snare. From that place there were signs of people having walked several times, so our hopes were renewed. Following said trail we were led over the hills sloping toward Andreafski River and into the ralley of another river which is rumning parallel to the former and emptying its waters into it near Andreafski village. On the opposite hills was found a nice little bunch of spruce, and in the midst of it were the long-soughtfor Lapps. So well were they hid that it would have been hard to find a better place of refuge from an enemy. They had said in Andreafski that they were in exactly the same place where I visited them last fall, and here they are 6 or 8 miles away from that place. What is worse still is that they are not even in the same river valley. It is in Nils Sara's tent I write these lines while Per. Sara and younger brother have returned to bring Bals, Nallogoroak, and the deer. It was quite interesting to witness the meeting of Per Sara with his parents. Per is a man of 20 summers, and as he has been parted from his parents several years I expected to see a very touching meeting. This, however, did not come off according to expectations.

The whole ceremony consisted in the following: Father and mother retaining their sitting position on the floor. When Per entered the tent, he first turned to his father and placed his right hand on the old man's hack. In return the father touched his son in a similar manner with his left hand. His salutation of his mother was done in exactly the same way. Brothers and sisters were touched by Per's left hand instead of the right; otherwise the ceremony was the same. 
Very few words were spoken the next ten or filtern minutes, and then Per went ofl to pilot the other wo men with the dere into the hiclden camp.

Per Spein is away in seareh of a road to drive the laced up the Tukon. This is his second day out, hut is expected home to-night. I hope he will come, so we can get ready to leave canpl day after to morrow. Our driving deer were let loose to join the herd immediatcly on their arrival this afternoon.

Tuesduy, November 24. Most of the forenoon to-day was spent in packing sleds and getting harnesses and lassos in trin. Everything seems to go very slowly. All the men started for the herd at noon to lasso driving deer for the trip from here to Bethel. This was not a small item of the preparatory work, since we will have need of at least 25 such deer. The day has becn most beautiful and quite cold. Is it looks to-night, there is good reason to hope for a beautiful day to-morrow. The moon is bright and the whole hearens set most magnificently with the lesser lights of the night.

Wodnesday, Norember 25. The last night's rest was certainly very poor. Some of the people in eamp have been working all night - at least ther have pretended so- and made a lot of noise. It 4 o'clock I was up and prepared breakfast, and at 7 a. m. Bals, Nallogoroak, and myself were ready to bring the deer for a start on the long and difficult journey. Per Sara had now joined his parents and continued in their company. But all those people needed at least four more hours in which to get ready. When we came to take our deer two of them had broken loose. The one was soon caught, but the other one ran for the mountains. This was unfortunate, but had it ended the mishaps of the day we could have considered ourselyes fortunate. Michael and Martin Saratwo lads of 16 and 10 years, respectively-had gone to bring the herd in our way, to be driren by Bals, Nallogoroak, and myself, with the said Michael. Sara and Spein, with families, should follow us closely after. Bals had his two deer all ready, so he drove on, while Nallogoroak and I got hold of the runaways.

Because of the one deer which went to the mountains we had one more sled than deer, so we arranged for putting two sleds after one decr until we could reach the herd. This would have worked woll for a few miles, but to our great mortification one of the deer given us refused to work at all. It was not broken to work at all, and when, after a hard struggle, we finatly got the harness on, it simply lay down. It was already a couple of hour's since Bals had grone with the herd, and Nallogoroak and I began to understand that these efforts were all in vain. The Lapps were not ready, and apparently did not care whether they got away to-day or to-morrow. Then I started at once in pursuit of the herd to stop it until enough 
driving dear coukl be procured and for all then to start at once. I took three sleds with me after two deer-one old sick decer and the other one the poorest of the lot that had come from Lnalakleet. Such was my rigging up for the trip) - certainly not very encouraging. Nallogoroak was left behind to join the Lappes with his load of provisions and tricky deere. After three hour's hard work I reached the herd and with it Bals and the two Sara hoys. They had grotten into a heary forest of spruce, birch, and alder, through which we had to cut our way for about a mile.

For this work I came just in time, and at $1.30 \mathrm{j}$ ). $\mathrm{m}$. we were through at the foot of a big hill and small brush as far as we could see in the direction we wanted to go. There we stopped for tea, butter, and bread, and after a quick luncheon, Bals and 1 , with axes in hand, started off either to find or to make our way through the brush. Some scarching and some cutting made a fair road for a couple of miles and enabled us to get out on one of the branches of the Andreafski River to the east of the rillage. It was already 3 p. m. When we returned to the foot of the hill where the driving deer and our sleds had been left. The herd was still up on the mountains from which we had begun to make our way, so we concluded it hest to look for a camping place for the night and await the arrival of Nallogoroak with the Lapps. As Nallogoroak had nearly all our provisions on his sled, our sup er was very meager this erening. Just at dusk I was up on the mountains to look if the omes waited for had not come, lut not one could be seen, nor a sound heard. The two Sara boys shared Bals's and my own scant supper and have now to sleep with us, the one in N.'s sleeping bag, the other in my hig deerskin parka and tucked down between his brother and myself. Nallogoroak is ecrtainly all right where he is with all his provisions in the Lapps' company, but it is sad not to be able to make a better day out of the first out. Delay after delay, and the precious time passing without any results from our efforts. To-night we are not more than about 6 or 7 miles away from their old camp, and not all here, so naturally our to-momow, if God grants us it, will also be lost to a certain extent. The day has been calm and choudy till near evening, when it cleared up under a light easterly breeze, which is gently shaking the sides of our dwelling, just sufficient to remind us of the fact that we live in a tent. About $s$ p. m. the moon and stars are bright, making it a beautiful night to travel. Marbe the rest of our company will arrive sometime during the night.

Thursday, November 26 (in the morning).-At 3.30 this morning I was up and started the fire and prepared what little we had for breakfast. This minute 6.30 a. m.-Bals started ofl in search of a way again, while I stay at home till daylight and then intend to go in a different direction. The boys are up on the mountains 
to gather the herd and to see if our company has not come amd camped somewhere in our vicinity. As l sat in the lont wombleringe what had beeome of the herelers of what the reasom might be for such a delay and waste of time, a well-known volee from the ontsicte was heard. It was Nallogoroak, who, in the early moming, fook a stroll about in the wilderoness to see if ho could find bals and mo. Ine had, in Sara's and Spein's eompany, arrived during the nightly homrs, but had taken another divide. so they had (oome down to the river about $1 \frac{1}{2}$ miles bolow us. There they had made camp and all was well. The decr which went to the mount ains was eanght and the one which fussed so in the morning was gradually trained and herame a good deer. So now, on Thanksgiving Day morning, the mumber is lull in both people and deer.

Thursday. Nomember 26 (in the evening). The moming promised a beantiful day and the promise has been made good. No clouds have hid the sun from our view to-day, and no wind of any lind has been felt.

Nallogoroak. Michacl, and myseif went after the herd where it was grazing before Bals's return. But in spite of all rushing and hurrying, it got to be 10 o'clock before we reached Sara s (amp) with the herd and our four sled dere and loads. There everything was perfect comfort and ease, joy and happiness, as if a thought of moving had never entered their minds. It that place we now took two more sled deer, and at 11 a. m. Bals, Nallogrorouk, Michacl, Martin, and I started to move the herd toward the mountains east of Andrealski dolta, at a point where the Iukon rolls its waters just at the hase of the mommtain. It was quite a task, since several miles of the way had to be cut through bushes. What made it specially hard to find the way was that the country is so level and the bushes so high that one can not look over and piek the best way. Bals and myself in the lead with an ax, each went along breaking the trail. The herd followed, and closely after it came Nallogoroak with our ioads. Moving slowly but surely along, we reached the foot of the momintas, a distance of about 7 miles, at 3 o'clock p. m. There we stopped to have a well-earned cup of tea with some bread and butter. Ifter lunch we traveled again, in the moonlight, another 5 miles, and a t. 6 o'chock we made eamp just on the bank of the mighty Yukom. We have not had a slimpse of Sara and Spein with all their sleds until this moment. They having followed our trail are now, nearly s p. m.. making their camp beside us. Yes, this is the day our friends in the states enjoy their delieious turkey. We feasted on a ean of roast heef for Thankisviring dimer, and! I declare that a beter dinner could not he served in the most luxurious dwelling in our land than this one enjored in an $\&$ hy 10 tent put up on the bank of the Yukon for this festive occasion. 
Friday, Nonember 27 . - The day has been a very beautiful one. A light northeasterly breeze has been blowing and it has been quite chilly, but not disagreeably cold. We began our preparations for the day's journey at 5 a. m., and at 8 o'clock all the sleds were packed and stretched out in a line on the Yukon. Nallogoroak and Bals went up on the mountains after the sled deer and the herd, while I walked ahead a distance of $3 \frac{1}{2}$ or 4 miles to an Indian village. The purpose was twofold, the chief one being to find ont the exact way to travel, and secondly, to see if any dry fish could be procured. Nallogoroak had not been himself for sereral days because of not having had any such food. On my way I met a native who gave me quite good directions to follow. That is, he made a drawing in the snow, because not a word of his language was understood by me. That same drawing I reproduced at once on a paper for future reference. Having arrived at the village the same inquiries were made, and again an Indian drew a map on the snow, and, when he had finished, I reproduced that one also. Upon comparing the two they were found to be exactly alike. Fish, however, could not be bought, because they seemed not to understand exactly what I wanted. The herd was expected to come directly after me, but again there was quite a little waiting to be done. Not until 11 o'clock did it arrive. Nallogoroak had then come nearly an hour before. He was able to get 5 dry and moldy salmon at 20 cents a piece, and 5 white fishes at 10 cents.

It is needless to state that we had a happy Eskimo in the crowd the remainder of the day. For some unknown reason, the young Sara lad was not accompanying the herd to-day. On that account I had to take his place to drive on the herd for the day. Bals went ahead and Nallogoroak followed as usual close after with our provision, tent, etc. If we had a late start, we made it good by the better traveling during the afternoon. No doubt a 20 miles distance lies between us here and where we were camped last night. We made camp at 4 o'clock. All has gone well except that I got a heary blow on my left big toe in running against a stump during one of my deer's wild outbursts in trying to run away. Now I sit in my sleeping bag having snowy applications to my swollen black and blue, not toe only, but foot. Sara and Spein have not showed up at all, and it will soon be $\mathrm{s}$ p. m. Likely they will not be able to catch up to-night.

Saturday, Nowember 2S.- This day has been a perfect day. True it is that the morning was a little foggy and dark, but it soon cleared up and a northerly wind has been blowing, and still continues, only a little stronger this evening. Last night after we had gone into sleeping hags and slept for a while Sara and Spein came. It must have been about 10 o'cloek when they reached here. And on that account they were, as usual, not ready again in the morning. Two new driving 


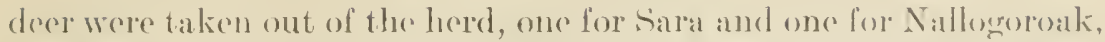
to reliere two others which stood the trip less woll. To the prepere lations of to-day was added the cutting and loading of ats much dry wood as we could possibly lake along, because after our last nierht is camp is left, there will be no rhance of getting amy wool, probably of any description, hefore wo get near Bethel.

All was ready and the drive began at 8.30 a. 11 . Ls wo were now across the Tukon and all its sloughs and brush, the vast tundral laty open before us. I due southerly course was takon by the compalssis and we have traveled all davaceording to it. It happened that a series of small lakes or ponds lay exactly in our way. These lakes some of which were as much as 2 miles in length are very nice to travel on, and between them is the best of feeding rround for the decr. It is certainly well to have the feed, but at times it gives us much trouble. The deer want to fred all the time, and as soon as we reach such a place of inoss they at once set off and spread out, so that. it becomes very hard to gather them again, for the next pond. Yaturally such trouble delars us, but still we are fortumate to have placed about 25 miles behind us to-day. Camp was made at 5 p. m., when we had traveled an hour and a half by moonlight. The deer bogan to be hungry, and Michael's voice as well as my own gave out entircly. so we were forced to camp before we had otherwise intended. No wood of any description is to be found for miles and miles, and the tundra is so level that hardly a knoll is seen anywhere. Sara and Spein arrived two hours later and made camp by our side, and all are ready to retire at the hour of 9.

Sunday, November 29.-The day's march began at 7.45a. m. That means, of course, we who escort the herd; the others, as usual, did not get realy at such an early hour. Having made about 20 miles, we made camp) at 4 ?. m., and are eomfortably situated to-night. But. at this hour - T jelock - the rest of our crowd has not yet come. I said we were comfortably situated. By comfort here is simply meant a few small willow bishes, in which the tent could he securely tiod. Wood for fuel has all, like last night, to be supplied from what. wr have on the sleds: conseguently we need to be very careful in casc it should happen to be had woather and a lay over be necessitated. The day has been cloudy and quite a strong northerly wind las heen blowing all day. All mountains have now sunk completoly below our horizon: so the compass is now our only guide when the sun is hid.

Just after our noon lumch of crackers and tea, I happened to slipon a nigrerhead and unfortunately sprained my riglit ankle, and was thus disabled to loun and chase the herd, but had to sito on the sled and bark as much as the organs of roice would allow. The pain is yet very aceute and it is certainly woll if I can sit and jump and jar on the sled 
at all to-morrow. The herd is doing excellently well. It is hard to drive orer these vast mossy fields since we are only two-Michael and I- to chase.

Monday, Nomember 30.- At 11 o'clock last night the Saras and Speins turned into camp. It 3 o'clock this morning when I woke up hearing laughter and talk in the Lapp's tent, I feared we had overslept, but the matter of fact was they had not yet retired, nor did they do so that night. Still they caused us considerable delay in getting rearly this morning. When the herd was brought at 8 o'clock some new sled deer had to be caught for Sara. This performance took them nearly an hour. Then Per was to take Michael's place to help me drive the herd to-day. We had, however, not traveled more than 4 or 5 miles when we were fully convinced that it was an impossibility to make any headway if we had not some more and hetter drivers. The deer began to seatter and eat everywhere. Per was too heary for so much ruming, and I being disabled by yesterday's accident to the extent that I had to sit on the sled and could do no more than drive after the herd and hark in place of the dogs. Two poor dogs were supposed to follow the herd, but they were not acquainted with Per and so they soon returned to the camp. At 11 o'clock we were tired and disgusted orer the result of our labor, and so we stopped to make tea and wait for Spein and Sara to come. When our luncheon was over the ones waited for came. Per and Michael and one dog at once followed with the herd, and at 4 o'elock we made camp, fully satisfied of having traveled some 20 miles, and to our great surprise all the rest of our party came to camp with the herd half an hour later.

The weather has been rery dark and threatening all day, with a northeasterly wind blowing hard. It started to snow this evening, but it soon stopped again. What should we do if an old-fashioned blizarard should start to sweep this level country, which affords no shelter at all, especially as there are some small children. One in the party is only 3 months old and another about $1 \frac{1}{2}$ or 2 years. It certainly behooves us to hurry on to more hospitable regions.

Tuesduy, Decembrr 1.- It 6 o'clock this morning we were all ready to start on our journey, but to our sorrow it began to snow very hea vily, so we did not dare to leare camp before daylight. A couple of hours later we started off in spite of the snow and did well. About 10 o'clock the snow ceased to fall, but it has remained rery cloudy and dark all day. A northeasterly wind has been blowing from morning till night. We have traveled fast and far. After having gone a comple of miles we struck ire. It was a lake, the length of which must have been at least 10 miles. On the latter was less snow, but still we did exceedingly well there also. Having reached the distant shore of the second lake we began to look about for a place to steep 
some tea, but there was no shelter from the cold, penetrating wind, nor was there any wood of any kind, and as we could inot afford to burn any of the wood we carried along, we simply continued on our way without tria.

Soon we came to an Indian village-2.30 p. m. Nallogoroak having gone before to bave all dougs chained or chosed in, I went also to incquire about the best way to Bethel and to lenrn how far we were from there.

Nünachăr! grinut was the name of the place. How far it was from Bethel in miles no one knew, bat they used to travel there in a day with a good dogr team. To our surprise we met a white man by the name of Twitchel in this lonely place of the north. I guide was hired to go with us to Bethel that we should be alble to get there without any necessary loss of raluable time. That man I sent with Nallogoroak to go with the loads on the trail ahead, while I went after the herd, which Bals meanwhile had dricen in an entirely different direction from what we should go. Some time later we had successfully driven the herd around the village to the southeast, but we wanted to go farther east still, and to do so we had to cross another lake. That proved to be a very hard task, because the ice was glare. One of the male deer belonering to Spein who had been limping on three legs all the way from Andreafski and was really in a miserable condition fell on the ice and walked very poorly after that fall. The best that could be done under the circumstances was done, in that Spein and Sara stopped to butcher it, while the rest of us drove on with the herd to catch up with Nallogoroak and the guide, who were a considerable distance ahead. Having accomplished this, we camper at 4 o'clock at the side of this lake. Possibly we can reach Bethel tomorrow if we get an early start.

Hodnesday, Decomber 2.-Four o'clock we were preparing breakliast and at $T$ our sleds were loaded, but as usual Spein and Sara were not ready and the herd had strolled off a long distance during the night, and it was not brought bark before 9 o'clock: then another driving deer had to be ('aught for sara. When at last we were off we were fully determined to make Bethel our next camp; but on alcount of hard traveling over 10 miles of glare ice and then a heary snow fall and thick weather we have not been able to accomplish our aim. It 1 oclock we arrived at a little village which is said to be half way between where we camperl last night and Bethel. All of us were hungrry and thirsty, so we stopped for tea. While tea was made, I took a walk into the village and met there a native by name George Spear, who had been oducated at Carlisle, Par. He is now doing erangelistie work here amomg his own people. Cieorge seems to be a very intelligent and practical man. The ald comeil house, in which the people have had their heathen festivals and dances, is now turned 
into a meeting house where le reads to the other natives the lifegiving word of God. One hour was very pleasantly spent there among the natives while tea was prepared in the camp and the deer had their lunch. George then followed me lack to the herd - in fact the whole rillage population followed to see the "tŭtín-tř," as they call the reindeer. Then we also had to arrange for a new guide to go on with us, because the onc we had had worn out his shoes and wanted to return. It 3 o clock sara and spein also arrived, just as we were ready to go on with the herd. For about three hours we traveled well, but then the deer wanted to eat, so we concluded we had better stop overnight and wait for sara and Spein, who again had gotten far behind. If any more snow should happen to fall they might not be able to find our trail. It is now 10.30 p. m., and our Lapps have not yet come. Where are they?

Thursday. Theember 3. Safe and sound are we all now at Bethel. All delars and all disappointments belong now to the past. Sara and company had net arrived when we began to drive the herd this morning at $\bar{i}$ o'clock. But we could not wait. so we marched on, and at 11 o'clock a. m. the herd was grazing 3 or 4 miles from the village of Bethel, while Bals and myself drove down to the mission. How pleasant it was to meet these dear friends and missionaries at Bethel. Nerer will the foelings that were experienced at that moment be forgotten. Those hearty handshakes and the pleasant faces and kiml words of weleome impressed me decply.

Dinner was served in Mr. Stecker's home. It was the best dimer I think I have ever caten. The afternoon was spent in talking about decr, missions, and natires. Bals returned to the herd with our sled deer before suppor, and will not return until in the morning. spein and sara also arrived a little before dark. So now all the herders and 400 deer are safe at the destination.

The wind has been the same, only a little more easterly, and quite strong. It has been very dark. The sm has not been seen for, I think, six days.

Fridey. Inecrmber 4.- The day has been a verr interesting one. I have visited all the three missiomary families and learned about the conditions under which they work here for the uplifting and betterment of the part of humanity which has come under their care. As stated, the missionary foree is made up of three familiesAdolphus Stecker, the niswionary in charge: Joseph Weinlick, the school teacher, and Mr. Heinz. Two native helpers are employed in the work. Both of them have recoived their education at Carlisle, Pa. The one is George Spear, who has already been introduced; the other is David, who is living at Bethel and makes trips to neighboring villages. The missionaries and myself were out on an excursion this afternoon to see the herd, but is it had gone several miles 
larthere away, we had all to return without serome it. 'The day has been very aloudy and dark, with a northeasterly wind hlowing quite hard. A litte sinow fell also in the forenoon. Mr. Sterkere and I have been talkingabout makinga tripup to the mission hord, which is nearly 100 miles away, but for various reasons it does not som possible to go there. The river is so very swift that as yot it has mot flomen, says Mr. Stecker, and the mountains are said to loc almost impassable. But should I go there I would run a great risk of not being able to return to Tualakleet in time to meet the appointments in regard to Mary's case with Lindseth. And if J do not return in time, Mary would not be able to do anything in the matter. So all things considered, it is better that this herd which we hrought be left in Mr. Streker's (rharge right here, and he take it up to the mission herel as soon as the ronditions be favorable. As far as wo are able to ascertain just now, not a single deer was lost on that long and troublesome journey, and no aceident happened axeret when the sick deer fell and hurt itself.

Saturday, December 5. - This day has reached its oud in much the same way as yesterday. The snow has lallen thickly all day, and the wind has kept up its speed pretty well. The barometer has nothing good to prophesy. We have now decided to leave next Monday morning for Cualaklert.

Sunituy, December 6 .- This has been a more than usually pleasant day. We gathered in the little chapel twice duringe the day, and were greatly hlessed by reading the old, but ever new word of Life. All the Lapps, except Mirs. Sara, eame to chureh, and rere made acequainted with the missionaries. 'They all stayed for dimer and roturned to the herd again before dark. Preparations were made for our start towarl home in the morning. After church this evening a man came down from the noighborhood of the Bethel reindere herd and told us that their herders, with nine deer, were just roming down to-morrow. So after all I might get a chance to sere some of the herders hefore our return. The weather has beon a littlo better' to-rlay.

Homday, Decomber 7 . - Somohow the night was almost slecpless. At 5 o'clock I was up looking and waiting for Nallogoroak and Bals, who were to come from the herd with our deer. IIour after hour passed and no one came. Dimner was partaliem of early so als to be in readiness to travel as soon as the Bethel herders and my own men eame. Two oblock in the afternoun, Bethel horders came with núne deer. Thoir deer.were in a most excollent andition. The herders were very niee and intelligent young mon. 'They gatres also a favorable report about the present condition of the hord, but several deer had died during the summer and arty autumn. Their trip down had been very diffeult beeause, as Mr. Sicelecr had 
said, there was no iec as yet. Tt had taken them seren days to reach the station, although they had rery light loads. I am very glad that we did not make an attempt to go there, because it would only have resulted in the wearing out of the few sled deer we now have and a delay so great that I most rentainly would come too late to Nome. Is Nallogoroak and Bals had not returned at 2.30 p. m., I sent some boys with a letter to B. to remind him that it was this very day that we intended to start for home. The boys had not beengone long, howerer, before Nallogoroak came with three deer. Of course it was too late then to go anywhere to-day, so he was directed out on the tundra to where Bals was waiting with the other four deer, and there to stake them all and return with $B$. to sleep at the mission over night. The reason for the delay was said to be that the herd had gone so far away that it took the boys nearly all clay to find it. Late this evening some travelers came to the village from up Kuskokwim River, and one of them brought the letter which I wrote to Mr. Stecker from Andreafski last fall, in which he was informed as to the plans of moving the herd. The weather has been very misty to-day, especially in the afternoon.

Tuesday, Drecmber S.- Five o'rlock I was up to see what lind of weather it was and to call my men to get the deer. But they, Mr. Bals and Nallogoroak, had already gone after them. The morning was calm, bright, and beautiful, promising a nice day. In spite of their early start, Bals and Nallogoroak did not return until s.30 a. m. At $90^{\prime}$ clock all was ready- two sleds loaded with wood, one with provision, and one with clothing, then one sled remained for each of us to ride on during the return. Farewell was taken and off we went quite speedily, taking a northwesterly course toward home. The whole day was calm and beantiful, but toward erening it began to grow eloudy. Camp was made about 2-2 miles away from Bethel, a little beyond a village by name Nesboangloakmut. We are very comfortably situated in the shelter of a willow hush, and have enjoyed our supper greatly because we had no lunch to-day on account of the late start. The wind begins to blow furiously now, late in the evening, and everything seems to indicate bad weather.

Wednesday, December 9. - Last night was very stormy. We could not keep the tent standing very well, but had to get up and raise it. twice during the night. At 3 o'clock the wind died out a little, and before $6 \mathrm{a} . \mathrm{m}$. we were ready to start the day's march. Just as the deer were harnessed up and wo held the reins ready to go, the wind came feartully strong and the snow with it. In such weather we could not think of traveling, so we made an attempt to put up the tent again. That undertaking was quite diffieult, but finally we succeded in getting slrelter, and then we remained until 10 o'elock. when we started off again. The wind had then gone down a trifle, 
but still it was protty stormy. Many a time during the day have our sleds bern blown sidewise and even rolled over. The smow has also continuod to fall throughount the day. Toward evoning we bogan to sec signs of our trip) here on the lst instant. Feom that wo mudersteod that we had found oul own trail again. Pleasant discorrery, indered. Te made (ammp agenin at + p. me, just by the side of a lake, and ane sheltered party by a bush and partly ly a litule knoll. Jad it hore light renough lor two hours more, we wemld have come to onr old (amp) of Norember 30. It seems now that our return would be ace(omplished much rasior than our (ooming, and naturally so.

Thursday, December 10.- It was raining all of last night and this morning and most of the forenoon. The snow is fast disappearing. The tundra is now practically bare, but by dividing our loads on all the sleds and walking ourselves the travel has gone woll just the same. The long lakes in our comrse have helped us greatly, and we are satisfied this crening of having traveled about 2.5 miles during the day. Before 3 o'clock it became so dark that we had to begin to look for a camping place, but as none could be found we continucd on our way more by foeling than seeing until jo oclock, when we found a few small willows, which afforded vory litte shelter, but there is no choice here. Ifter the tent was tiod to the sleds and bushes we cut a lot of small bushes a foot or two high and tied them together in bundles and then fastened with rope these bundles on the windward side of the tent. Hardly were we settled in camp before it began to rain again, and it still kept on at bedtime, or rather sleeping-bage time. Mbout two days journey from here are very few lakes to cross, so it certainly looks bad to have to drac over the heary moss fields without any snow. As we are lightly loasled we hope to manage it, but naturally the progress must be very slow if this weather continues. Hu! it is lonely out here; the coaseless wind tearing and shaking our little home, if anything, more furiously than ever as the hours go by. It is by the wind's lullaby and a constant lear of the tent blowing over that we crawl into our bags to-night. "But joy cometh in the morning."

Fridey, December 11. Ifter a rery stormy and ramy night the firmament cleared ofl and it was brighter than ever. The sams wind continues, but it is perfoctly dry and much colder than yesterday. The little bit of snow that is left is now crusted and the niggerheads are covered with frost, so that the sleds slide quite easily. On aceount of this pleasant change of weather we have traveled well to-day, probahly 25 miles or more. ()ur camp to-night is beter than it was last night. Wro are located near a littrereek. with sufficiently stere) and high banks to give us shelter from the

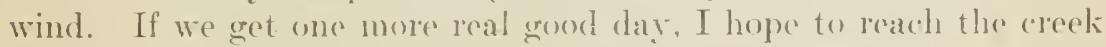
through which we gain exit from the tundra and across the Yukon. 
Saturday, December 12.- It 6 o'clock, while yet dark for about three hours, not seeing where to go, but having taken our course by the compass and then noting the wind, we went on accordingly. It was snowing and blowing all forenoon, so we eould not see anywhere. Somehow Mr. Bals seemed to favor a more westerly course than what we should have, and every once in a while I had to call him and try to explain my riew on the matter. It helped for a while, but soon we were back again in the same old direction.

After tea, at 12.30 o'clock, the sky cleared for an hour, so that we could see and fully recognize where we were. We were so near that the trees along the Iukon were plainly visible, and had we not gone so much to the west in the forenoon it would have been an easy matter to reach that river to-day. After being shown so exactly where to go we happily continued, but had to make camp at 4 o'clock in some willows. We were not able to find the timber, because it began to storm rely hard. The sleighing is getting better and better the nearer we come to Andreafski. If this weather continues, we might get plenty of snow for the use of our snowshoes, which hitherto have been almost useless.

Sunday, December 13. - The night was very stomy. Our tent blew over at midnight. Nallogoroak and myseif were thus given a little extra exercise in getting our home safe again for habitation. As it was sunday to-day, we made no rush in the morning. It was nearly half past 8 before we left eamp. Fortunately we soon found our old trail again, on which we conld easily find our way across the Yukon. At the early hour of 2 p. m. we had reached the nearest moss-covered hill to Andreafski, on the east side, or about 6 or 8 miles distant. Here we made camp again and stayed overnight. The whole day has been elear, cold, and calm. The possibility of getting home by Christmas is becoming greater every day. In another week of such travel we hope to be in St. Michael, and then we are only 60 miles from home.

iLonday, December 14.-To-day has been a pleasant one. No special difficulties have been encountered besides the ordinary trials of trail life, and in fact they have been less than usual.

As the deer were feeding quite far from our camp last night, and it being a dark and cloudy morning, it took until \& o'clock before we got started. The trail to the village was good, and in a couple of hours we were in Andreafski. Our provision stored there was again received and packed by Bals and Nallogoroak, while I risited and administered medicine to some sick people. When this was done, Mr. Petre invited us all to dinner.

It 12.30 p. 111. the march began anew. Mr. Bals thought we should follow the river some 2:5 or 30 miles up rather than go over the nountains, as we did in November. Ten or 11 miles were easily 
eovered during the short afternoon. Wo lawe plenty of wood and good sheltar as long as we trarel in among the momentains. A northerty wind has been blowing all day, but not hard.

Tuesday, December 1.5. All days can not be cqually bright, nor ean we be equally suceessful every day. As stated festerday, we

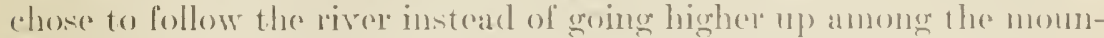
tains. All went well as lar as we knew the river perfeetly, but soon wo came beyond that himit, and we traveded all foremonn mot acoumplishing more than :3 milas. The snow became locsere and derepere the farther up we anme, and no possibility to get ofl from the river either, because of timber and hrush. About noon we reached at place where the mountains were tolerably steep, and there was not so much brush on the side hut what we could make our way though. Once more we were on the momntains, where reindere travelers really belong. In pure delight we made at onee a big camp fire and had our tea. The afternoon has been much more profitable to us than the forenoon was, but still the day's aceomplishment is not by any means what it ought to be.

It has been dark and snowy all day, but mot too much so for one to travel with comfort. The wind has been northeasterly and very gentle. The great lear we had a few days ago on the Yukon tundra, that all the snow should go away and we have to come home in boats, has proven itself groundless. 1 good lesisom, indeed, "not to worry for to-morrow." Never could the snow be more nearly right for traveling than what it is just here where we have gone to-day. On account of darkness we were obliged to make camp a little before 3 p. $\mathrm{m}$.

Wedncsday, December 16.- So another day with its strugrgles and pleasures is orer. While yet.quite dark this morning we were off on our homeward march, and at 3 p. m. camp was made exactly on the same spot as in the evening of Norember 18. If we had gone the best and shortest way, this place could have been reached at noon and to-night we could have been near the portage, where cxit is made to the plains again. But Bals got lost to-day and woukl not go the way Nallogoroak and I said, now proven to be the right one. The day has been beautiful. Nowinds.

Thursday, December 1r. This day has been the brighitest one we have had on our return trip. All the clouds had disalppeared this morning. The air was fresh and it was cold. As the morning, so the day has continued to be. Camp was left at 7 o'clock. At tea time we had just reached the summit of the divide which separates the headwaters of the tributaries of Andreafski and those of P'astolik River. 'There is no language by which to describe the splendor of such a noon hour. On the one side is the rast level tundra, which from the mountain tops looks like an ocean of snow. Is far als the eye 
can reach there is not a break, not an elevation. On the other side is a eleep basin inclosed by momntains of varions sizes and shapes. Back of these again are other peaks which rival cach other in raising their hoary heads towand the heavens, and, though it be only the Aretic December sun which illuminates their mantle of snow, the splendor is mexcelled. Never ean tea be trunk in a more luxuriously prepared erystal palace, and never could it taste better than it did in this big and great palace of nature prepared by God Himself. We could not but feel grateful for being privileged to view this scene in the splendor of noon. It $t$ o'elock camp was made among some low alders on the slope toward the sea. We are now about halfway between Andreafski and St. Michael.

Friday, Decembor 18 . This has also been a beautiful day, but very cold. There was a light northerly breeze all day, and as we traveled right against it our noses were quite troubled in that they had a tendeney to turn white and hard as soon as they were left to themselves for a few moments. Still none of our party had any serious results from this fact. 'This evening oul camp is just in line with a little knoll on the sea, the name of which is unknown. Cape Romanoff could be seen a few minutes before dark.

Saturday, December 19.-Camp was left before 7 o'elock this morning and we have traveled quite well all day, and are to-night camped a few miles to the east of Cape Romanofl and in a direct line with it. To thaw out our frozen meat was specially difficult this evening, because we have 110 more rood on our sleds and here is nothing to be had but very small and green willows that ean hardly warm themselves, much less anything else. It seems coleler to-night than it has at any time since we left home.

Sunday, December 20.-St. Nichael,. $10 \mathrm{p} . \mathrm{m}$. At last we are here after a pretty hard day's tramp. The trail on the coast from Pikmiklatik to St. Michael was most excellent, but the moss fields were far to the east of our course, and we being desirous to reach St. Michael to-day made use of a portion of the night to accomplish our task. The weather has been beatiful to-day also, but it became foggy in the evening, and before we knew it Mr. Bals was lost and could not be found. Of course Nallogoroak and I could not stop and search in such a fog. So we continued on to our flestination well knowing that Bals would show up there either this evening or in the morning. He had some food on his sled and also sleeping bag, so in reality there was no danger and we tried to not worry about him.

Honday, December 21. - I spent last night without sleep, partly because of Bals being missing and partly because of lear of dogs. At 7 o'elock a. In. I started ofï across the bay for st. Michael to see if Bals had come there, and while I was gone Nallogoroak should wateh 
on the canal and on the tundra to see if lie eould see Bals coming and stop him till my return.

On my arrival at the Northern Commercial Company's place Bals had not yet eome, hut shortly after breaklast he also came. Ile had been sleephing on the tundrat, 2 miles away from on ('ample, and claimed his errand was to look for me. It may Je so, Jut ehamers ane

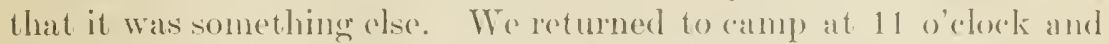
got ready for our journey toward Lnalaliket. To-night we ('amp) about 5 miles away to the south of 'Tlicketarik. It has becm sumwing all day to-day and a cold northerly wind has been blowing. In St. Michael we had the opportunity to communicate with our dear ones at home by telegraph, and to our great pleasure and romfort they are all well.

Tuesday, December 2D.-- Because of great darkness we left camp later to-day than wo usually do. The iee we have traveled on to-day was very had. Some of the deer broke through. Three of our sleds are not provided with steel rumers, and on the salt ice, with slush on top, they slide as heavily as il one were dragging over gravel. One of our deer got tired and refused to walk, so on that aceount I had to take that one sled also on top of my own and let the deer go loose. By (j o'clock we made ('amp) near Galsovia-a native village aloout 30 miles from [nalaklect-hoping this to be our last camp before reaching liome.

Wednesday, December 23.-- Early, while yet dark, we prepared for a final break-up. The steds were repacked so as to leave one of them at Galsovia until another tine, and thus enable our one tired deer to travel loose. The trail was good, and in a couple of hours we had reached the well-known Devils Gulch. There the decr were given an hour's rest while Nallogoroak and I took the sleds down that steep and rocky hill and placed them in order again on the ice helow. It that time two dog teams overtook us, and as deer and dogs do not travel well together, we allowed the dogs to go ahead a mile or two. Ten miles farther on is a coal mine and that we realched at 1.30 p. 11 . We stopped for tea and gave the deer another hour's rest, and at 5.30) o'elock camp was made. * * * But this time our tent and stove were not needed to make us comfortable for the night.

We are home once more among our dear ones. 111 is woll. C'hristmas preparations are all finished and we have arrived to join in the festivitios.

Very respectfully,

C. O. LaxD,

Suprintendent.

Dr. Sheldon Jackson,

Washington, D. C.

s. Doc. $61,58-3-7$ 
MEMORANIDA CONCERNING REINDEER DOETE BETWEEN BLTIEL AND COJPEL CENTER, MLASKA.

\section{DePARTAENT OF THE INTERIOR,

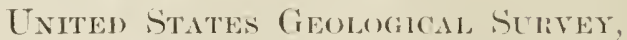 Wrashington, I). C... M/a!! 3, 1904.}

DEAr SIR: I inclose the two Alaskan maps, with the proposed routes practicable for reindeer indicated in red from Bethel on the Kiuskokwin, to Copper C'enter on the Copper. 'Through the crest of the Alaskan Range I have indicated three passes within a distance of 40 miles, which are numbered respectively 1,2 , and 3 . The southern or No. :3, which makes a great bend to the south, is the one used by Mr. Spurr; but I find on consultation that the others (1 and 2), which are both shorter than the southern, are also perfectly practicable for reindecr, having been used by pack horses. Mr. Spurr says that the Kuskokwim Indians know and make use of these passes.

Having passed the Alaskan Range and gotten into the Sushitna Basin, at the suggestion of Mr. Eldridge who has ascended the Sushitna and reports the going fine for pack and sledge animals on the high gromnd between the Talkeet and the head of the Sushitna and an asy passage to the Copper, I would recommend the upper or northern route, and do not believe I should take the southern unless compelled to diop down to some post at the mouth of the Sushitna for supplies, etc., in case of emergency.

Tery truly yours,

Dr. SHeldon JACKson,

F. ('. SCHRADER, Geoloyist.

Lnited States Bureau of Education,

Eighth and $G$ streets $I I I$., Wrashinglon, D. C.

$$
\text { Cincago, Ilı., April 2\%, } 1904 .
$$

Desr SIR: I have delayed answering your favor of April 6, but it arrived in due time, also the map, for which accept my thanks.

In measuring the distance from Bethel to Copper Center by the upper route and the lower, I find the distance to be about the same both ways. and if I were to take a herd from one place to the other I should surely solect the lower route. It has many advantages, such as known territory, moss, and mostly timberless, as well as casy to resupply necessities. The upper route may be good, but no one knows what there may be, except that it is a timbered country and therefore slow to travel through without a trail of any kind: then, too, there may be wolves encountered and other unknown or unforesecn obstructions. My plan would be to send a small supply of food to Bethel and the 
bulk of it (1) Nushagak Mision mow in the summere hy schooner" then 1 would he on the groum! hy December 1.j or so, and start the herel from Bothol with a lierht supply and make a fast run to Nushagak, where I would find a lesupply, rest a little, and then start for the real trip up the Koichak fo Iliamma Lake, follow that Joely of water to (lark lake, from where I would coros to Cook Inlet and travel on the sea iee up to the head of the bay ge to Knik villagere, then follow Knik River up to the lake, and then cross to Coppere Center. 'The ardvantace would still be lareor hy having a little supply placed at Cook Inlet, about at Toyomok Mission.

There are so mainy aldrantages in being able to travel on rivers and lakes that they can not be described, and a herd can be driven twice as fast on a lake as on land, because there is no food to tempt the animals to linger. They can be driven on a trot the whole day and at night brought to the shore, where lhey will be busy feeding orer night and will not have tine to roam about and scatter, but will be ready in a bunch for the next day's travel.

Tell, Dortor, these are only my personal views, and the man who goes can surely do as he pleases and pick his omn way.

Yours, truly.

SHELDUN TAChisos.

WM. 1. K.JELLuAx.

Washington, I). $C$.

ANNUAL REPORT FROM TELLER REINDEER STATION.

By T. L. Brerta, in charge.

Teller Rejneer Station, July 14, 1904 .

Desr sur: I herebr submit the anmual report from this station for 1903 and 1904 .

During the summer, fall, and early winter the herd was kept north of Grantly Harbor, on Sunset and Rock creeks. In January it was removed to the usual winter quarters on the Iriapuk River. The hool disease raged in the herd, causing many deaths, especially among the fawns. In May the herd was moved aclosis the bay near Berine, and is now 4 miles southwest of Bering, where it has dry ground and good pasturage. The fawning season was favorable, 37!) surviving the season of 1904. Mrs. Brevig and children left for the outside. July 12, as her health made it neressary for her to get a change. October 12 Mrs. G. Weeks and Miss II. Natas alrived, alter a most hazardots and trying trip) from Nome to Toller, to help me during the winter: but lailing health made it an absolute necosity for me to go outside, so Mr. A. Ilowick ollered to stay during the winter, and 
I left the station Oetober 14, Teller Octoher 17 , and arrived in Seattle October 28.

School was kept regulariy all winter and spring, report of which has been sent you by the teacher, Miss Naas. On my return, July 3, I noticed great progress, especially in ability to speak English. Carving and drawing was also taught, besides sewing, housework, etc.

The health of all has been good. In June, 2 children, a girl 1; months and a boy 4 years old, brother and sister, were taken into the home, the mother dying from consumption, and the father, a white man (they were legally married), gave them into our care.

Wood is now so searce that we have to depend entirely on coal for fucl. In February, 166 lemale deer were delivered from the herd at Cape Prince of Wales and accepted. Two females broke loose from their fastening before they were tumed over to Mr. Howick and ran back to the Cape herd, making the total 166 instead of 168 .

Through Mrr. Frank Kleinschmidt the mission obtained the contract to carry the mail from Teller to Marys Igloo and from Teller to Cape Prince of Trales. The round trip to each place is about 140 miles. Serawlook, a mission apprentice, made 14 round trips to Marys Igloo and 10 round trips to the Cape, or about 3,300 miles, from November 1 to Jume 1, with reindeer, generally driving double, or with two deer to one sled. The majority of the white people ridienled the idea of reindeer bringing the mail throngh on time or competing with dogs, also of having a native drive the mail. Results were a surprise, cren to those who believed in the deer. Ife always made good time and on many trips exceeded the best time made by crack dog teams under the most farorable conditions of travel. One round trip was made in twenty-seven hours, three hours faster than the best dog team has ever made it in the last five winter's. Some trips were made in thirty and thirty-two hours. The longest time required 36 hours.

The trips to the Cape were also made in all kinds of weather and always under unfarorable conditions of travel. Scarcity of moss along the coast, rough ice, and heary trails, make a detour into the mountains necessary. The arerage time on this route was four days for the round trip.

During the winter Sckeoglook's apprentice, Ehrmak, was discharged on account of disobedience and unfitness for becoming a decrman. Kozetuk was also suspended for disobedience, but as he promised to become a good deernian (he had served three and a half years) and always been a grood worker, he was on my return to the station, on pronise of obedience in the future, again taken in as an apprentice.

I arrived at the station July 3 on the Charles Nelson, and will remain at the station until the beginning of September.

Mr. Ludvig Larson cane in with me and will take my place and in 
the future render the necessary reports, arcounts, ete. Suljoined please find account of groods for herders, deer aceount, ote.

Very respectfully, yours,

Dr. SHELDON JACKSON,

T. L. BHEVIG.

General Agent of Eilucation for Alaslia,

ITashington, D. C?.

ANNUAL REINDEER REPORT, GAMBELL, ST. LAWRENCE ISLAND, ALASKA.

BY E. (. Camprell, M. D., in charge.

Dear Sir: Permit me the horor herewith to submit my third annual report of the reindeer herd at this place, for the year ending June 30, 1904.

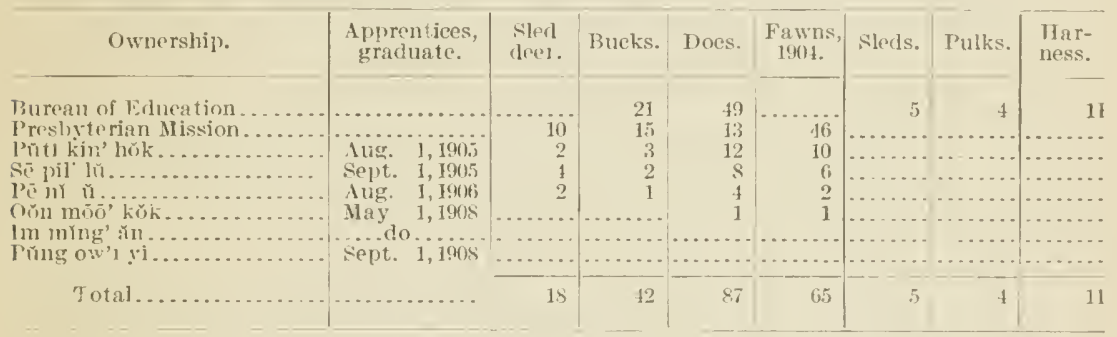

Girond total, 212.

The winter has been an unusually mild one, and the herd did well until the spring, which the Lapps report as a hard one for lawning. We lost 14 fawns from rarious eauses, and two were killed by dogs from the village 15 miles away. Some of the fawns were from nothers born in 1903, also from mothers only a year old, born in 1902.

When this is carried through the three or four generations, the progeny become so weakened as to readily suceumb to slight changes or inclemencies in the weather, and the mother's' instincts seem not to be fully developed, for they sometimes desert their offspring. The herd is now on entirely new ground, inspected partially by Per Larsen Anti and Sepillu two years ago. Near this place we hope to find some means of erecting another winter camp. It will be about 35 miles from the station, but in the center of a fine moss pasture entirely unused. A move of some kind has become necessary from the long feeding on much the sane range and from the increase in the size of the herd. We expect to kill a mumber of males in July and August and experiment a little in the curing of meat. Anti reports St. Iawrence Island as too marshy for the continued lassoing connected with milking and cheese making. The marshes 
and bogs soften the leg bones to such an extent in the summer that niany broken legs would be the result of much chasing a herd. This seems to us quite reasonable, though we know, too, the Lapps here took no pains to secure dried stomachs of deer, the rennet of which is a necessary element in the Lapp process of making cheese. Anti says the Lapp women do that sort of work and the poor man smiled a sad smile because he had no wife. We have saved up a lot of reindeer horns and hoofs, waiting for recipe and apparatus for making gluc.

$A$ corral is much needed, especially in the fall, when marking and castrating time comes, and when the fur is best for clothing. Reasons above mentioned.

We should also feel very grateful for some good dogs from the mainland. If Lapp dogs ean not he found or procured, perhaps you could get some genuine Scotch collies, which I think could stand the climate and surely have the necessary intelligence.

\section{TIIE APPRENTICES.}

We wish we had more cause to speak encouragingly on this subject. Whether the fault is with ourselves or with the boys, we can only state things as we see them. There have been no open breaks nor any attempts at riolence, owing to the efficient management of Mr. Thomas Richards, to whom we have largely committed the care of the Lapps and herders; but there is constantly present a desire to deceive. If the boys were alone and entirely away from the influences of the old men of the village they would do rery well, but I know that the old men are counting on a big killing of deer as soon as the boys' time is out. No one here seems to grasp the idea that any one ever does anything for them but to further his own ends, and exeept for the single element of fear of the powers of the United States Government rested in the revenue cutters, there is no authority over them apart from their own thinking-verily the traditions of the elders. We found a promising young boy last summer, an orphan from Plover Bay, Siberia, who wanted to become a herder. ITis guardian gave consent, with full knowledge, but in the winter when we took the boy, "Pung aw ř́ yı̆', "into our own home for the school, and to remove him from the filth and rermin of the guardian's home, the guardian objected, and had we not been firm about it would have taken him. We had five children with us in our home all winter, and he was the best one. He did his chores promptly and well, and seemed eager to learn. Many, many times he would draw a way from the other boys and quietly come into the kitchen where he could wateh Mrs. Campbell.

Physical fear of Richards has made the larger bors more careful in their treatment of the Lapps, and the same thing induced an increased activity on the part of the Iapps, so that the hoys have 
made remsiderable progress in loarning to break and drive the sled

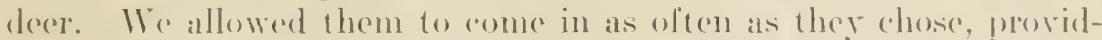
ing they wombl drive deer, until they got to neglecting the herd, when regular times were sot. Par Larsen Inti is an excellent deer man, and posiesses the pualifications of a shopherd. Ife knows the porsonality of nearly arery dece in the herd. Were he only a married man his worth and infuence would be far greater. In our opinion ('hristian homes are the foundations of all stable governmonts and cnduring civilization. Ole Pulk has been far from satisfactory. With a strong-minded American or Lapp constantly in the camp, he might do good service, but as it was wo thought best to remore him May 1, since which time he has lived in the Brach IIouse with Mr. Richards. Richards has been able to toll the boys of the eagerness of the roung men on the mainland to secure herds of reindeer, and that has had a good influence on the boys. so that they have conducted themselves much more satislactorily during the last few months. Shut in on an island of small population, idoas are narrow, and only become broadened by contart with those from outside. Seeing more outsiders and remored from the influence of the old men of the village, with an efficient teacher among them, the six boys we have would compare well with any herders I have read of. We hope to have some women in the camp this winter, a much-needed element, and a most necessary one before the camp will beeome a home.

One of the boys is very anxious to secure a wife from some other people. The people here are intermarrying to such an extent that the whole village is like a large family, and unless steps are taken for their relief they will soon be gone.

Inother matter under this head demanding rour most careful consideration is the future of the boys who graduate. What provision is to be made as an initial outfit for the young herder at the time of his gradtation? What is to be given him beyond his 50 head of deer? There is no market for meat here like there is for herders on the main land, neither any stores where a herdor could sceure needed supplies by purchase or in trade. There is no freighting to be done for miners nor other means of earning money, and at the same time preparation has to be made for weather perhaps severer than most of the herds meet on the mainland, because there is no protection from the severe winds so frequent here in winter. Tents can not stand, nor do they suflice for protection. Fuel is another serious problem on account of an absence of timber. Driftwood is only found along portions of the north side, and the brach is allotted among the different houses, so that each one has his claim, and for another to take wood from any place but his own is considered and treated as "claim jumping." 
I would respectfully recommend that each boy graduating be given a rifle and a shotgun with 200 rounds of ammunition for each, cooking utensils, bedding, a few articles of household furniture, rope and sled (wood and steel runners), a good supply for one year of cereals and recretables especially, some good clothing, and a cabin, to be located after consultation and agreement with the superintendent.

\section{TIIE SCIIOOL.}

This is the most promising and encouraging feature of our entire work. We deny that we are discomiaged - that we have the blues or any form of liver complaint-as some may infer from certain statements in our report. That we have made mistakes and that the work has suffered by them we admit. That others could have done better we most firmly believe, but by the grace of God we are what we are, and in the name of our Lord Jesus Christ we shall lammer away until something breaks.

Dr. Arthur J. Brown, a most careful, practical, business-like secletary of the Presbyterian Board of Foreign Missions, says it will take two or three generations to make good strong characters of the Filipinos. Similar testimony could be produced in regard to work among any people so far lost as these. While education can never produce character, it will most effectually banish superstition and devil worship, and we can see these things are fast losing their hold on the younger people on the island.

To more fully appreciate the attendance on sehool during the year it will be necessary to bear in mind the census figures, which are as follows:

Agr :

Census figures, Gambell, St. Latrence Island, January 15, 1904.

Under 6

Brys.................................................. 14

Girls . . . . . . . . . . . . . . . . . . . . . . . . . . . . .

6 to $1.1-$

Boys... . . . . . . . . . . . . . . . . . . . . . . . . . . . . . . 29

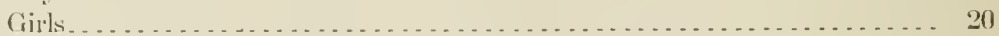

14 to $21-$

Boys. . . . . . . . . . . . . . . . . . . . . . . . . . . . . . . 30

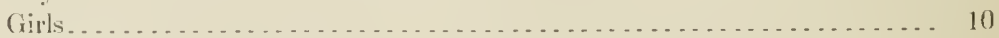

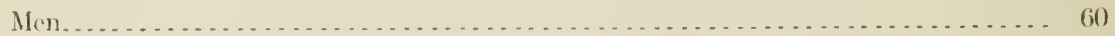

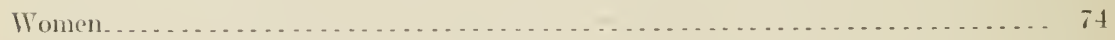

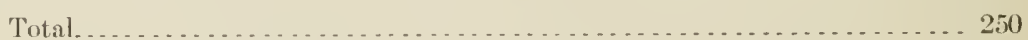

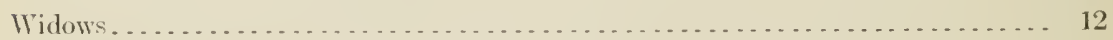

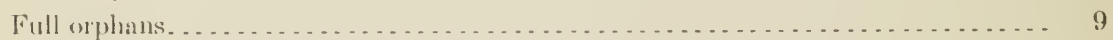

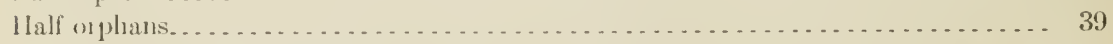

Now from this population, increased by the arrival of 19 , the entire population of the small village at Southwest Cape, in the first 
week of April, we had an enrollment of fit. two of whom were boys belonging to Southwest Cape and came only duringe April. Furthere, the three roumerer leinderer alpperentices did not (o)me into seluos mutil 'Thankegriving, and many of the boys were away more or less during April for the whalingr season. Notwithstanding all this and the lact that the school is composed of savage pagans we have the following record of attendance for one hundred and thirty-four days from October 1 to April 30 :

Inays absent .............................

Times tardy ..............................

Number of pupils.................... 14 6 $6 \begin{array}{llllllllll}1 & 1 & 2 & 1 & 4 & 2 & 1 & 1 & 2 & 3-10\end{array}$

'The average attendance for the year was (i1, more than treble the attendanec in 1900 . We latre pursmed the same policy of making the sehool the most attractive place to be found on the istand. 'The magazines you have sent did most excellent service, and we trust you have sent a fresh supply for the coming winter. Many of the illustrations were used in traching new words and have been the eause of many questions.

Mrs. Camploell assisted me the entire rear, taking six classes in the morning and four in the afternoon, though she had more other work than she could do. The crowded eondition of the sehoolroom, the as yet uncontrolled habit of studying aloud, and the necessary confusion from two classes reciting at the same time, when seated side hy side, made tearhing a great diffeulty, and yot we are pleased to eonsider ourselves privilonged in being permitted to be a linht in the darkness here. Appended is the programmo of our daily exercises and on anothor sheet an epitome of the class work eorered by each grade. Two of the older boys came this rear onty because I insisted so strongly and promised them they need not come any more. But the school has more attractions for them now and they are anxious to go to Carlisle, only the parents are holding them back. No one has yet gone from here to America and all are afraid to make the start. Tire shall be so grad when the first one has gone and ran come back and tell others what he has seen. There is more noed of work among the women and girls than among the men and boys, and we should be so glad if a new and separate building could be put up and a lady assistant employed so the sehool could be divided. There are six or eight children who should be admitted this rear, but we do not feel like earrying the additional burden, nor havewe seats for them.

We belicve the size of the sehool and the interest manifested would justify the erertion of amother schooloon and the employment of a lady primary teacher. 
COURAE OF STTDY, 1903-4.

1 class: Seven girls and 23 luss. Appleton's Reading Chart to No. 27. Counting, adding, subtracting up to 10. Copying on bodrd and slate. Changing printed to written letters. Parker's Arithmetic Chart to No.9. Naming objects and conversation.

B class: Eight rirls and 3 boys. Appleton's Reading Chart. Counting to 100; adding and substracting to 15. Parker's Arithmetic Chart. Seat work, copying. Dictation of words learned. Conversation, naming objects.

First grade: 'Three girls and 10 boys. Part of MeGuffey's First Reader, daily. Crr's Primer to page 100, daily. Parker's Arithmotic Chart to page 17, daily. Penmanship twice; drawing once a week. Dictation: reading lessons, twice a week. Spelling, oral, written, daily. Sewing cards for girls.

Second grade: Five girls and 4 boys. Cyr's Primer completed, daily. Cyr's First Reader to page 66, daily. Prince's Arithmetic, Book I, page 37. Spelling, oral and written, daily. Dictation, stories and reading lessons, twice a week. Pemmanship twice, drawing once a week. Conversation. Sewing cards for girls.

Third grade: One girl and s boys. Balwin's First Reader completed. Crr's Second Reader, daily. Parker's Arithmetic Chart, daily. Prince's Arithmetic, Book II, to page 21. Penmanship twice, drawing onee a week. Conversation. Spelling, oral and written, daily.

Fourth grade: Eight boys. Appleton's Seeond Reader, complete. Balwin's Second Reader to page 60. Milne's Elements of Arithmetic to page 74, daily. Penmanship twice a week, Drawing weekly. Spelling. Dictation. writing some reading lesson, twice. Letter writing. Conversation.

Fifth grade: Seven bors. Appleton's Third Reader to page "How to Talk" Language to page -. Milner's Elements of Arithmetic to page - Barmes's Geography and Map Drawing. Drawing once a week. Penmanship twice a week. Spelling, written and oral, twice a week, with a home-made dietionary of words learned. Journal, weekly, writing of events. Conrersation, correction of sentences. Singing, naming of States and capitals.

Wednesday erening class: Twenty-one young men. Reading, "Story of the Gospel." Explanation of wording. writing them on blackboard; map talks; board ilhstrations, talks on geography, etc. Singing. Playing of games, and tea.

\section{BLIIDTNGS.}

In July we began the construetion of the long-hoped-for hospital. The lumber was not dry, and some of it was yet to come on the 
supply schooner, which did not reach us until Lugust 2s. But we sharpened up the tools on July 22.2 preparatory to the buildinge and made some cold chisals. With the help of some of the boys, alsarrered July 227 as "Boll Founders' I) ay," removing tho leavy boll from the roof and refitting the collar to prevent as severe rocking whonever the bell was rung. July gs was "Blacksmiths" J)ay," becantse wo made somo necessary tools; July 29 was "Stomemasoms" I)ay," hecause spent in getting out stones for foundation. The next lom days were devoted to the "County Association of Architects," becanse plans for the new building were drawn, the scale besing one-twelfth inch to an inch. August 3 actual work bergan with six men helping me. The services connected with the laying of the corner stone were held August 6. Work was continued until the 26th, when we could go no farther until wo knew if more lumbor should come. Notwithstanding the eontinual vigilance necessaly to the best work and to make the lumber gro as far as possible, the work with the men was very pleasant and I an sure profitable to then. Ther learned much English and also the use of some of the carpenter's tools. The square and level have come, to those that worked with me, to mean something rery definite and cxact, and they also learned a little of the white man's use of diagrams and plans. As mistakes were made, each one had his share of the jocular querr, "What's the matter with__ asleep !" at which all would laugh, and right glad were they when they found opportunity to laugh at the hired carpenter. The addition consists of the hospital, 16 by 16 , separated from the main building by an entry which has been used all winter as a much-needed reception room and wash room. In the shed adjoining is a storeroom, a bathroom, and coal bunkers for the schoolroom. The wash room and bathroom may be called a part of the hospital equipment, cleanliness constituting a letter medicine than all the drugs obtaimable. 'The bathoom was used a crreat deal.

()ur plan was for four to go to the lake one-fourth of a mile a way and get water, which we put in a larese tank in our kitchen stove. When the water was hot the boys filled up the bath tub and two of them had their fun, when two more put in more hot water and washed off all the dirt the water would hold: so with hot water, plenty of soap and wash rags and towels the four came out, if not white as the smow. improved at least 300 per eent, the usual returus expected from expenditures in Alaska.

'The walls of the building have double air spaces, and the roof and floors single ones, making, as we know from experience, a much warmer room than if the walls had been put against each ofher. Is soon as the Laura Jadsen came and the supplies were piled under 
cover we made haste with two boat crews to move the reindeer camp house to a better place, where it would be nearer to moss. This was a hard, tedious piece of work. The house wis torn down in al light rain, the lumber loaded on two boats, which had to be portaged from the sea to a lake, then towed along the lake beach for 2 miles and disembarked. Everything was then carried on the backs of our people over the spur of a hill about 1 mile to the shore of Nan nook Lagoon, where it was again put in boats and taken about 2 miles from the sea to a good location. Nan nook Lagoon is navigable for large ships, but the entrance is so shallow, only whale boats can get in. The house was reerected, the walls packed with deer moss, the roof allowed air space with an outside covering of t-inch flooring and a good coat of paint. $A$ shed was also built over the doors and bunks put in both the boys' room and the Lapps'. By the time this was done the rough fall weather had come and the sea was so stormy we could not launch a boat.

We made a trip to the summer camp of the herders, gare them a list of deer to be marked for each apprentice, and killed a deer for meat, as our food supply was getting short. At last we dismissed most of the boys and let them walk home, with instructions to return for us when the weather modernted. But the weather did not moderate and at last we had to walk home and leave the boats and most of the camp ontfit. Fortunately my dogs had become lonesome and came to hunt us up, so we cut up some canoes, improvised harness. borrowed a deer sled and "mushed" 17 miles orer lakes, rivers, swamps, and mountains to Gambell. Besides Mrs. Campbell and our two small Eskimo boys, were two Eskimo women and anotler little boy to whom the trip was anything but play, thongh all stood it well.

Two weeks later Mr. Richareds took a crew and put up a small winter cabin on the shores of another lagoon, to give room for a change. of the herd. There should be more of these houses at different places over the island.

The beach house was repaired where some robbers had broken the door during Mr. Egan's absence two years ago, and the floor braced up to allow coal to be placed in the shed. The entire house is nothing but a shell and will not answer for either dwelling or storchouse. Te think it could best be utilized hy removal to the village, placing it on a proper foundation for use as an assistant's residence.

With the use of a few large timbers, the entire building could be moved intact, by means of large blocks and tackles now in possession of the people.

We have spoken of the need of winter quarters for the herders, who have no means of securing them themselves and could not be blamed if they deserted their herds and came in to the warm houses of their 
families in the village. In riew of the facet that the lives of the people of this station rirtually depend on two hanrests of seal and wallus, the lailure of either of which would throw the inhabitants inte at famine, it would secm highly proper that al good supply of staple food products should be kept here continually. and a proper huilding crected for the purpose. When the ice eomes in the carly winter, seal and walrus are usually quite plentiful. Between . November 1 and 1, 190:3. 111 seak were killed, and from Norember 2s to December 16, s1 walruses, the cold weather enabling the people to keep the meat. This catch, with the few killed during the winter, supplies the larder until about the time of the breaking up of the ice in spring, when another catch is made which tides them orer the summer. Ducks, fish, and eggs, with whale meat and skin, complete the diet, adeded to a small amount of white man's provisions obtained in trade for whalebone, ivory. and fox skins. Last year there was between $\$ 30,000$ and $\$ 40,000$ worth of these valuable articles taken from St. Lawrence Island, for which the people did not receire much more than one-fifth or one-sixth that amount. 'This year one of the boys brought me a bundle of whalebone asking me to weigh it for him, which I did and found it contained $1+$ pounds. The same bundle was weighed aboard one of the whalers and the weight announced as 9 pounds, and the boy given a new .4t-caliber Winchester rifle-sst for \$12. Rather large gain to cover handling. Sometimes a good trade is made to make a good impression and the man is caught for a large deal as well as many of his liniends, for everyone tells ereryone else of the trade he has made.

This is a well-known adrertising scheme in the business world, but sadly successful among a people so ignorant of the true value of what they get. It this connection I would say I do not believe the Gorernment teacher's and missionaries in Alaska are getting the lowest rate obtainable, but our isolation puts us in a position where we can not lave a choice. Many of the present erils of trading will disappear when the school gets a larger hold on the people, and those now in school have grown to years of maturity. We should be very glad, indeed, to see a stanch, stiff hackboned Christian business man here for trading alone. It would pay. But it is laard to have one kind of teaching going on all winter, and the direct antagonist coming with the ships in great power in the spring. Whisky or other alcoholic drink is still used as a trade or prostitution inducer, though not so openly as in former years. The method often practiced now is for the party of the first part, white, Portuguese, or negro, after trade, adultere, or prostitution to place the licuor in reach and go away. If it is taken he does not give it, and so escapes the letter ol the law. Words well-nigh fail to express the discouraging tendene'y such artions have on our work. 
Many of them cam not see why the white men should have anything to say about what the Eskimos should do, for the Eskimos were here long ago. Aroning in this manner they resent the use of their young mon as reindeer boys; the killing of their dogs when chasing the deer; the recental attendance of children at school; the punishment of disfurbers or criminals; and, in short, any interference. Some are awakening and becoming willing to be taught and led a little way. Then asking one of the most influential men here if he would not send lis boy out to school he told his boy, "Yes, if the white speak strong" (i. e., insists or urges). Let the authorities compel payment for that $\$ 2,000$ or $\$ 2,500$ worth of bone taken nuder false pretenses, stolen, and the influence of the action will be very great indeed.

ETINOL,OGICAL NOTES.

Mr. Thomas Richards has done efficient service in the preservation of order and instilling into the minds of the people a wholesome fear of the Government - fear being at present if not the only at least the most cflective means of controlling them. Though the people here, and Eskimos in general, have to pay large sums for "treatment" by their native doetors, the only evidence I have that anyone is grateful to me for the medicine given or surgical relief is the fact that they are coming to me more than formerly, and I see less of the native doetors' charms worn. They do not earry anything for use nor perlorm any mamner of work, but I am sule to heal some one say, "No pay?" They have a custom hele that the man who gets a whale shall give grown peopleon the beach when the whale is landed one or more slabs of bone, the value of which may lange from $\$ 2.50$ (a small shab) to $\$ 450$ (being the market price of 10 large slabs of whalebone), and yet he will see that you give him some return.

Everyone on Sit. Lawrence Island is assured of a house, food, and clothes, if enough can be gotten, whether he gets them himsell or another one is the successful man. Iast spring the whaling barkentine Norning Star, Capt. James Tilton, took four men from King Island for the cruise. Returning in the fall Captain Tilton could find no one on that island, and not knowing the cause he concluded to get. us to take them here or carry them on to San Francisco. Upon consulting with our people four homes were opened to them and all winter they fared as well as anyone hele. From these men I obtained the census of King Island, which shows 80 males and 57 females, they having gono orer the people house by house. In this connection it may also be interesting to grive a comparison of a few words from each language: 


\begin{tabular}{|c|c|c|c|}
\hline linglish. & Puint latarrow. & Kings Islatnel. & St. Iatwrence Islamel. \\
\hline 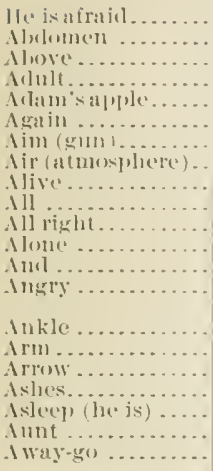 & 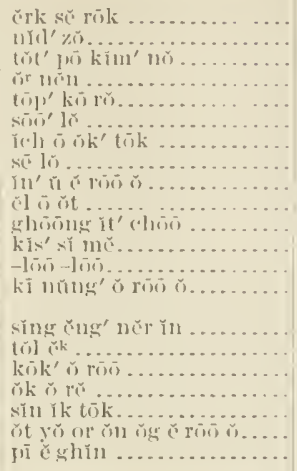 & 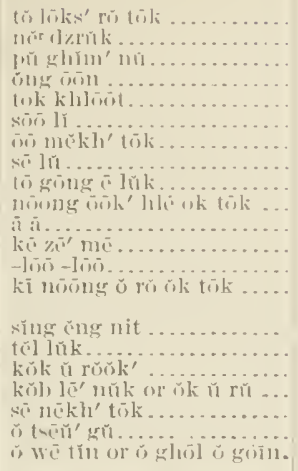 & 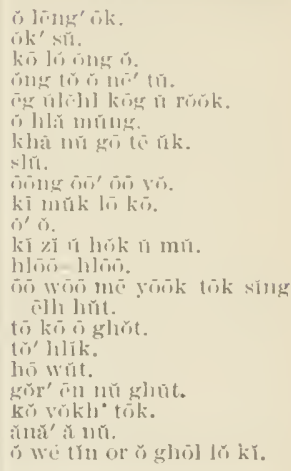 \\
\hline
\end{tabular}

The great similarity is noticeable eren in so short a list of words as the above, and many apparent differences woukd ranish were we possessed of a fuller knowledge of all the langltages. For instance, the

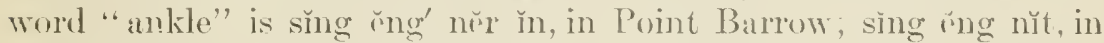
King Islanel; and singr' cth hut, in St. Lawrence Island. This in our language refer's to the constriction of the leg at the place where the boot straps seng' it -are fastened, whith would also be the word used if we were speaking, "My ankle is broken." But the bones and flesh composing the ankle joint woukl be more property interpreted, to kón 'ồ ghwot.

There is a set time and a certain sign for heginning erery game played by children or old people, and woe to the one who presumes to break the prescribed rules.

When the sun begins to change his course and moves with ererlengthening strides across the narrowed southern ate, the sages of the land eall upon the young scions of the house to get small billets of wood, about 6 inches long and 2 inches in diameter, to which is fastened a small piece of wallus rope sone 15 or 20 inches long. This is used as a bat for knocking small stones or lumps of snow or iee. When the ice comes a walrus is killed and the meat is drawn over the ice; two large whale vertebre or other objects are set up some 30 or 40 feet apart as goals, and three or four couples ol boys at partners begin throwing rocks at the goals to upset them. The rules are much like those governing the Scoteh game of quoits or our American game of horseshoes.

When a whale is killed the boys make small canoes and play with them in the house only, and throw darts with a pieces of cord at atcheth, having a loop in the end, which is eaught over a small perg in one side of the dart. With only one whale the dart may be thrown only away from the sea, but with two whales the dart may follow any direction. 
Also when a while or a baby walrus is killed they make a sort of bolos sling, the halls of whirh are mate of rolls of old walrus skin about an inch in width, and begin the favorite game of handball. In this a large ball about 5 inches in diameter is mado of beautifully pieced red and white sealskin, and stufted with deer hair. Usually the boys and young men are pitted against the girls and young women, and playing begins in the first patch of ground showing through the snow. As the days lengthen and the nights are so light, one could read all night; playing often continues all night, and during May and part of June sleeping is done in the daytime.

Two whales killed permit the use of toy canoes on the snow of the beach. Toy canoes made of a mitten, with its inner edge for the bottom, are used when a female walrus and her baby are killed. The same sign indicates the use of the sling, but the stones may not be thrown toward the sea unless two walruses and babies are killed. These slings are of the same pattern as that with which David killed Goliath, and are used with great skill by some.

No rules govern the playing of the white man's games, so checkers and dominoes go on all winter.

\section{GENERAL DEPORTMENT AND MISCELLANEOUS.}

We have had ver'y little trouble with the people this year'; indeed, the longer we stay the more do we seem to be a sort of house of guardians for the population. It is true we have to pay for every small thing done, but this is both our own wish and teaching, and would be expected by a people so poor and sick as these.

One big man last fall attrmpted to compel me to pay him his own price for helping to land the goods. He was furious for a while, threw off his coat, rolled up his sleeves, and threatened a messenger I sent for Richards, but soon cooled off, and is now quite friendly and apparently grateful for relicf from severe pain. He, with many others, would be greatly benefited by a vegetable diet, being sufferers from a form of scurvy due to an excessive meat dict.

In December Mrŭ kok, an Indian Pointer living here, a most troublesome fellow indeed, beeame enraged at his wife and hit her over the head with a big block of wood, cutting a frightful gash. Richards sent for him and some of the older men, delivered them all a good lecture, and put Mrŭ kok in charge of the old men; to be kept until the arrival of the Thetis. It was the same man who on several oceasions threatened Mr. Doty and Doctor Leri'go, one time nearly breaking in the door with stones. He and his brother also beat me on the beach in the spring of 1902, when the Indian Point boats arrived. The people here would be glad to see these two removed.

Indian Pointers are a hard lot, tyrannical and overbearing, even to the forcing of tribute from the St. Lawrence islanders. One 
of them took some 15 or 20 pounds of ivory lion Ifkowan, fatleer of Sepillu, one of our herders, and others are continually threatening and intimidating our people into griving of anything the Indian Pointers want. I called at Asshoonu's house one day just in time to abort an attempt of this kind by the son of the old Indian Pointer chief, Koworrin, who threatened to fight Asshooku il he did not give up some whalebone. 'These people always bring licuor with them, too, for there is no restriction as to trading such stuff on the Siberian coast.

In February one of the men, Hokh ko okh, drove his dog team too close to the sled deer which were staked out not far from the camp, causing one to break loose and run away, while another was so badly bitten it was thought for a while we would have to kill it, but we brought it to the station, housed it in the deer shed, and nursed and doctored it for two months, when the weather had so moderated and the snow sufficiently uncovered to permit of his being sent to the herd, where he is doing finely. The man was impressed into providing deer moss for the deer as long as it was in hospital, and we shall set a fine upon him as soon as the Thetis comes.

In May, three dogs, nearly starved, belonging to a lazy fellow named Koloo ku, went to the herd, over 15 miles, chasing it and killing one fawn and so injuring a second that it died. The boys killed all his dogs, which so enraged him he said we should have to pay for them and he would kill some deer. He had previously threatened the hoys and tried to intimidate them, so Richards took hin outside my house, where the conference was being held when he demanded pay for his dogs, intending to take him down to the Beach House and explain things to him; but on the way he attacked Richards, who, however, was too much for him, and put him in irons, from which he was released on the word of the old man who holds vassalage over him. On this case also we are waiting the coming of the Thetis.

There has been considerable liquor made here this winter, and some traded from the whalers, but we do not despair of its final extermination.

The medical work has increased and demands much of our time. It would seem to us as right for the Government to furnish a supply of medicines as it is for the surgeon of the revenue cutters to do such work, and no one would think of questioning that.

We feel much encouraged this year. There are beginning to be seen signs that the seed sown has fallen into good ground. Some blades of grass are even showing, and in due season we shall reap if we faint not.

A great moral and physical improvement in the condition of the people would result from a direct and specific order from Washington

S. Doc. $61,58-3-8$ 
to commander of the revenue cutter calling here, to enforce and direct a thorough elearing of the village grounds of the bones and vile rubbish, so profuse on every hand, and the designation of certain places where such garbage shall be thrown.

There are enough men and women, boys, and girls here to make short work of the job, and I am sure all would feel proud of the result and be incited to a like cleansing of house, person, and soul.

Trusting the work of the year may meet with your approval, that you will not spare us your valued suggestions and counsels, and that you will sustain us with continued mention before the throne of Him who holds us all in the hollow of His hand, I beg leave to subscribe myself

Your obedient servant,

\section{Edgar Omer Campbell,} Superintendent St. Lawrence Island Station.

Dr. Sheldon JACKson,

Washington, D. C.

Vital statistics, June 30, 190\%.

Population of Gambell:

Under 6 years-

Boys.................. 14

Girls ................ 15

6 to 14

Boys................ . 30

Girls... . . . . . . . . . . . 20

$1+$ to 21

Bors. . . . . . . . . . . 23

Girls.................. . 3

Adults-

Men . . . . . . . . . . . . . . . . 67

Womnn................ 83

Total ............. $\overline{255}$

Widows................ $\overline{12}$

Orplians.................. 9

Half orphans. . . . . . . . . . . 37

Births:

Males.................... 10

Females................. 2

Deaths:

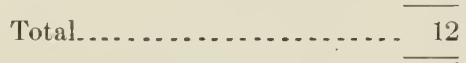

Infant males
Deaths - Continued.

Adult male ................ 1

Infant female.............. 1

Total................ 5

Population at Pōn wō'wầ lǔk, Southwest Cape:

Under 6 vears-

Boys................ 1

Girls................... 1

6 to i4

Boys................ 1

Girls................. I

14 to 21

Bots................ 2

Girls.................. 1

Adults-

Men.................

Women............... 9

Total.............. $\overline{19}$

Widows.....................

Orphans. .................. 1

Half orphans................ 2

Grand total............ $\overline{\overline{274}}$ 
ANNUAL REPORT OF EATON REINIDEER STATION.

By C.unl O. Liso, M. I)., General Superintendent C'entral l)ivision.

\section{[TXLAKLEET, ALASKA, Jun, 30, 1904.}

Sin: I have the honor to submit to your consideration my annual report of the work which has devolved upon me as supervisor of the reindeer herds and apprentices in Alaska for the vour which terminated .June 30,1904 .

Early in the morning of July 25 the pleasure was granted us to welcome Mr. Hamilton, the assistant agent of education for Alaska. His stay with us was brief, but the time was well spent. Is the mission at Unalakleet had previously had the promise of a herd of deer, this promise was acted upon. Mr. Bals, sr., was appointed chief herder for one of the herds at Unalakleet, while Ole O. Bahr still was to hold that position over the other herd. As ret there was but one held, but on Mr. A. E. Karlson's suggestion it was decided that it be divided into two and kept separately. It was also decided that Mr. Bals, jr., should go to Nulato to fill the place to be left by Isaac Bango. Is I had previously received an offer of appointment from Dr. Sheldon Jackson to the position which I now hold, Mr. Hamilton confirmed the same.

Bals, jr., was willing to go to Nulato at once, and as soon as the necessary preparations were made he left Unalakleet to go from St. Michael with the first hoat of August. Lpon Bals's arrival at Nulato, Bango returned and came to Enalaklect. The instructions in regard'to his being sent to Port Clarence arrived after he had reached Unalakleet. He not being willing then to lay out the money for his jomrney, I having no more to expend. he was delayed at Unalakleet until September 21, when he decided to go on his own risk. During Bango's stay at Unalaklect we received a letter from the local superintendent at Port Clarence to the effect that no Lapp was wanted at that place. But after all, when having had repeated instructions from headquarters as to his sending, and Bango at last being willing to lay out the moner for his fare, I let him go in the evening of September 21. On September 23 I received a telegram from the Commissioner of Education to dismiss Bango for the rear. I acted upon the instruetions immediatcly, but that letter must not have reached Bango until the local superintendent Brevig and Bango had formed an acquaintance and liked each other quite well. So Mr. Brevig wrote Doctor Jackson about his satisfaction with the Bango family, and a second telegram was received from Doctor Jackson on Norember 9, the same day I had left for the Kuskokwim, that Bango could continue in service. I having already gone, Mr. K. J. Hendrickson, the missionary in cluarge, wrote Mr. Brevig and Bango to that eflect. 
According to instructions received, I left Unalakleet on August 26 en route for Andreafski to see the herders, Spein and Sara, who had been left in Andreafski Valley last winter, after a vain attempt to reach Bethel, Kuskokwim, and also to arrange for their provisions until in the winter, when they were to be moved to their destination on the Kuskokwim. I arrived at Andreafski on August 31 at 10 o'clock a. m. A boat and a native were hired, lunch prepared, and in a little over three hours I was at the herders' camp, 12 miles up the Andreafski River.

Mrs. Pèr Spein had given birth to a child only four days previously, and there she lay with the infant, having very little to eat and no milk, this article not even to be had in Andreafski. An order was taken for provisions for both families for three months' time, which I promised to send them from St. Michael. The herd was inspected and found in good condition. The feeding ground near Andreafski is most excellent, and the deer had been doing very well. At 6 p. m. the same day I was back again at Andreafski, and as the steamer Leah, the boat on which I came up, was there yet, I bought some provisions and sent back to Mrs. Spein for her use, until the order from St. Michael could have time to arrive. Mr. A. Stecker was informed by the letter, which was sent by George Fredericks, who was just ready to go to the Kuskokwim in regard to our plans for moving the herd in the early part of the winter. The next morning, September 1, the steamer Rock Island steamed in on her way to St. Michael, and on September 2, at $10.30 \mathrm{a}$. m., she arrived at St. Michael. The orders for provisions were filled at the military post and the goods freighted up the river on the Northern Commercial Company's boats, and that same evening I arrived at Unalakleet aboard the mail steamer lleteor.

The 2d day of September the mission herd was counted and marked.

In the middle of September J. T. Lindseth brought suit against Mary Antisarlook, one of the chiel Eskimo reindeer owners, to recover, as he said, money which he had paid on her account; also for work which he claimed to have done in Mary's employ. Though late in the season, Mary and I had to leave Unalakleet for Nome on the 9th of October, there to report upon the summons. Ice had then aready begun to form on the Unalakleet River, making it very lard to get out to the open sea in one of the small native schooners of the place. A strong northerly wind was blowing, which, before we were able to reach the outer end of the channel of the river, had driven the water" out so that we were not able to get over the sand bars. There we hung, and had to be content from 2 o'elock p. 11 . till after 9 in the evening, when we finally got away en route to St. Michael. 'The next morning; October 10, we arrived, and in 
the evening were able to avail ourselves of the last chance to get away aboard the steamer Elli, bound lor Golofnin and Nome. The 12th of October we landed at Nome. We arranged our business by placing the case in the hands of Mr. A. J. Bruner, attorney at law. $\Lambda$ telegram which was received from the Commissioner of Education with request to have the trial postponed until the summer of 1904 , was presented, but as the plaintifl and his lawyer were not willing to listen to it, the trial was set for February 1 to 10, 190.t. October 15. we boarded steamer Ohio, and the next evening we landed in St. Michael. But all of our baggage was left aboard; though some of it was valuable, we were refused the landing of it. The next day the Ohio left St. Michael without sendingr a particle of baggacre ashore, and, as we have learned later, she took it all to the States. On the promise of having either the Meteor or the Sudie to take us home, we waited and waited for two days in St. Michael, and then suddenly the bay froze up during the night of Oetober 1s. For Mary to walk home was out of the question, so I had to leave her in St. Michacl while I walked home, a task which took four days to accomplish. Mary was sent lor later, when the ice hecame strong enough to travel on.

Immediately upon my return from Nome, Oetober 22, I had corrals made for counting and separating the herds. Ole Bahr was to have charge of his own, together with those belonging to (Okitkon, Tatpan, Moses, Episcopal Mission, Stephan Iranhoff', Bikongan (Bigone), Moses Kautchak, Jacob Kenik, and the Govermment, while the following herds were left in N. Bals care: Tnalakleet Mission, Nallogoroak, Mary Antisarlook, Kaktoak, Angalook, Sagoonuk, Aceibuk, Avogack, Amikr Avinik, Frank Kautchak, and Sakpelliok.

Since many of the fawns had to be separated from their mothers, it was quite hard to keep them in the different corrals until the work was finished. In fact, we had to let all the deer out on the fourth day of our work, while one more corral was constructed, that we might thereby be cnabled to do the work quicker. By having three corrals insteal of two only, as has always been the custom, we could do fully twice the work in a day. It was a perfeet suecess after the third corral was finished.

To rectify any mistake which possibly had been made in the first day's count, we intended to recount the one herd after our return from Kuskokwim, but for two reasons it was not done. First, it was rather late in the season to lasso the female deer; and, secondly, my time at home was short and well oceupied by correspondence and preparation for the trip north, etc.

On the morning of November 9 I left Unalakleet in company with 
Nils Bahr and Nallogoroak, who were to make the round trip with me to Bethel, and Per Sara joined our company to meet his parents in Andreafski. We found the herd and herders near Andreafski on the 23d of November. On the 25th the onward march began with the herd toward Bethel, Kuskokwim, which place we suceessfully reached without any accidents, and all in an excellent condition, on December 3d. As far as we were able to ascertain, not one deer was lost. True, one old male decr, belonging to Spein, fell on the ice when crossing a lake and hurt itself so that we found it best to kill the same, but that deer ought to have been killed before, because it had been sick nearly a year.

Adolph Stecker, the local superintendent at Bethel, took the charge and responsibility of the herd and herders right then and there, and was to take them on to their special feeding ground, 100 miles to the east, as soon as climatic conditions would allow. Thus I was free to return so as to be on time for Lindseth's and Mary's case, which was set for trial February 1 to 10. A report was obtained about the herd and herders at Bethel, which was really encouraging. Some deer had died from various eauses during the summer, but in December all were well and thriving. $\Lambda$ s there was no Laplander at the herd after Bals left, the native herders had all the responsibility, and they had proven themselves fully capable of doing their work. The best of feclings existed between the local superintendent and the herders, as well as among the herders themselves. These herder's have taken much to the deer and they love their work.

According to a letter from Mr. Stecker, the herd which we had brought from Andreafski and the Lapps ali reached the Bethel reindeer station on January S." Mr. Bals, Nallogoroak, and myself started on our homeward journey on the morning of December $S$, and on the 23d of December we safely arrived at home, Unalakleet. Some of our deer had then made the round trip from Unalakleet to Bethel and back and traveled easily 30 miles the last day out. Between Andreafski and Bethel those deer were traveling loose with the herd, but all the rest of the time and distance they pulled their load of from 100 to 200 pounds over a very poor trail.

On January 23 I started for Nome to be there in Mary's defense. Mary, her husband, and two witnesses from Unalakleet left here a

a When Wasely and Tanny were here, only Mr. Spein went up with them; the herd could not go; it was no worse on the ice nor tundra. Mrr. Spein, Robert, and Henry came down again just at Christmas; so we had the Lapps all here; onty the two boys were with the deer. They left December 29, and have come to their homes January 8 all well. I will mark the Government's division, to take only females, down in the book.

Wr. are without any news from the outside. December 15 , the two boys here named were the ones that came down at the time we were there. Spcin only followed them at the time, but then they returned and all went up to their camp.- Writien by A. Stecker, Bethel, January 18, 1904. 
few days earlier, so as to be sure to come on time. In Golofnin I took Rev. O. P. Anderson with us as a witness, and continued onward to Nome, where we arrived in the evening of January 31. Mary and her party arrived there the same day. 'To our sorrow, we found that the date had been changed and the trial set for the 29th of February instead of between the 1st and the 10th. Mr. Bruner, our attorney, went with me to Hon. Mlf. S. Moore, and after hearing with what eosts and trouble a journey like ours was undertaken he kindly changed the date and asked to hear our trouble on February 15. Meanwhile I intended to make a trip to Port Clarence, but as I ought to visit Cape Prince of Wales also at the same time and as it was not possible to make both places in the eight or nine days given, I did not go at all; and it was well that I did not, because the days passed rapidly by under the burden of some very important work before the 15th. The 15th eame and the 16 th also, and in the evening of that day the jury closed by sending in a verdict for the defendant. Mary was considered free from all Lindseth's elaims and Lindseth never had been employed by Mary. And thus Mary, with her herd, was saved from ruin.

Just as the business for which we had come to Nome was finished, it was my intention to go to Teller and Cape Prince of Wales, as Doctor Jackson had suggested, but conditions developed which entirely changed my programme. An opportunity was unexpectedly presented to demonstrate in a more special way the utility of the reindeer to the white population of Alaska and at the same time to earn quite a little sum of money for the herders. It was the question of taking a contract to haul 7 tons of freight from Fish River to the Imachuck country. This was my position: Either I should take the contract or else the deer would not have a chance to demonstrate what they could do and how much they excel dogs, horses, and mules when difficult traveling is in question. But should I take it, my original plan must of necessity undergo a complete change. Time would not allow me to go by way of Port Ciarence and Cape Prince of Wales, but I would then have to go back to Golofnin and there gather as many deer as possible and go on to the destination of the freight, and then continue my way north to Cape Blossom, while the herders were to return to Fish River after their second loads, and then meet two more men from Unalakleet, who were to bring 15 or 18 deer from that herd to join the Golofnin deer and men in their work. It was only after a great deal of consideration that I dared to tackle the matter-not for fear of not being able to carry it through, but because of the revolution such an undertaking would cause the scheduled plan of my travel. But finally, together with O. P. Anderson from Golofnin, $\mathrm{I}$ signed the contract and agreed to take 3 tons of oats and 4 tons of hay across the Seward Peninsula from Fish River to Chicago 
coal mine on the Kugruk River. At once we returned to Golofnin, and on the 27 th of February 18 deer with as many sleds were stretched out on Fish River at the mouth of Neukluk. Two thousand seven humdred pounds of oats made up our first loads, together with our camp outfit and provision, making about 200 pounds per deer. And so our journey began. The snow was deep and loose on Fish River, making it very hard traveling, and storm followed upon stomr, so that out of the ten days it took us to reach Chicago Creek nearly four were spent idly at camp. The deer travel just as well and almost better in bad weather, but we could not see where to go, and for two days it was so fearfully cold that had we been out it would have been an impossibility not to freeze.

Upon reaching our destination, the Sth of March, we unloaded at once and began the preparations for an early break-up the next day, and in the morning of Mareh 9 the two Golofnin herders, who were to continue freighting, were sent back with their 14 deer and as many sleds, while Tautook, the herder, Pjarak Rock, our guide, and myself, with four deer, continued our way toward Candle, Kewalik, and Cape Blossom.

Saturday, March 12, we safely arrived at that place in good condition, in spite of a fearful storm which had been raging. Some men that traveled with dogs had been on their way from Candle nine days, having been laid up by snowstorms umable to travel, and arrived at Kotzebue thirty-five hours later than we. Deer are the best.

The deer were staked out for the night and we ourselves were well taken care of by Mr. and Mrs. Dana Thomas, who are in charge of the Kotzebue Mission. A very unfortunate thing happened there, in that some dogs had during the night of our arrival gone out to the deer and killed one belonging to Tantook. This is the only accident met with on all my travels during the season.

Monday, the 14th of March, after a visit to the school, we intended to go to the herd, but the weather changed our plans. Instead of traveling we spent the day very pleasantiy, much the same as on Sunday in the school. In the forenoon the work of the school was enjoyed and in the afternoon we devoted between two and a half to three hours to a talk on the subject of hygiene, to which not only the school children were invited but the grown population of the village as well. The evening was given to Rock for preaching to his own people and in their own language. Hardly anything could be of greater pleasure to a servant of the Lord than to see with what an interest and eagerness every word semed to be grasped by his audience.

The following morning we left the mission for the Kotzebue herd, which was on the mainland about 25 or 30 miles away. Tlie morning was bright and beautiful, but it was hard traveling because of a lot of 
loose snow which we had to plod through. 'This, together with the face that the way was moknown to us, took us all day and part of the dark evening to get there. The next morning, Mareh 16, wo inspected the herd and fomd it in good condition, cxecpting the las that there were no shed doer. Seeing that one of onr deer was killod and the other ones had made such a lomeg and hard jommey lofore, one could not expect them to make the rotum trip, so I asked for liesh driving deer. 'They wore griven willingly, but as I said there wore hardly any of that kind. 'The conseguence was that one of the lot was only a year-old male fawn which was broken partly, and one 3-year-old deer which we had to break oursolves as we traveled; a thirci one had gone the long way from Point Barrow and arrived at liotzeloue only a few wecks previously. So with one decr which was really a fresh driving deer, one fawn which we drove only half a day on the trip, one unbroken deer, one which had traveled from Barrow a short time before, and one Gololnin decr which we wished to roturn, we started south about noon that same day.

At Kotzelue, as in Kuskokwim, I found peace and harmony between the local superintendent and the herders, as woll as among the herders themselves. I had a long talk with the horders and for the short time they have had the deer they have taken so much to them that they would not be without them for any price. Frank Nilima, the chief herder, had also the highest of eompliments for the Eskimo herders as well as for the place. It certainly is an ideal deer camp. It is well sheltered and there is an abundant moss supply for the deer, and wood and water of the best quality for the herders. Fish and game are also plentiful. Isaac Hatta, a Laplander, has been staying with Nilima for some time and was there at the time of my visit. Now, having heard that there were two Eskimo boys, Orpelle and Electoona, or Electure as he is also called, staying some 60 miles or so up the coast toward Point Hope with a herd of reindeer, I made arrangement with said Hatta to go and bring those two boys to the Kotzebue herd at onec before the fawning season began. Said boys had left Point Barrow early in the fall, en route for Kotzebue, with some 130 deer together, but never eame farther than Cape Cavalino, where they stopped with some other natives and squandered their herd. By letter from Dana Thomas ${ }^{a}$ I am informed that above boys

Dr. C. O. Lins,

"APRIL 15, 1904.

Unalakleet, Alaskia.

Dear Doctor: Hope that you reached home safely and found all well there. Isaae Hatta left for upper coast a few days after your departure. The Barrow loys did not wish to come, but finally agreed to do so and reached mission during my alsence at Candle on April 3. I found thems at reindece camp upon my return. The two had 123 deer upon arrival here. Sixteen had died or been killed since leaving Barrow. Deer in very bad condition and natives pretty hard up-in fact, they haven't anything that they need and have 
arrived in Hatta's company with 123 deer on the $3 d$ of April. Sixteen deer had been killed since they left Barrow and the living ones were in a very poor condition. The herders were also in want of tent, stove, provisions and all. Mr. Thomas reports also cold weather and a loss of one-third of the fawns at the time of the letter.

The mareh toward home, as said, began on the 16 th and after five and a half days' traveling we had reached the mouth of Neukluk on the Fish River, with the deer, as stated above. During that same time some men were there who traveled with dogs and it took them almost twice the time to cover said distance. At Neukluk, however, a three days' delay oecurred because of rain which made the deep snow so soft that one could not travel by any means. On the 26 th we sueceeded in getting away, and after a very hard day's tramp we reached the Golofnin herd nearly at midnight, and there again the weather bound us another day.

The Golofnin herd was also in a most exeellent condition. It was beyond doubt the best herd I have seen this winter. Their feeding ground for the winter was also an ideal place. The herders are doing very well. They show interest in their work, and there is no reason why the native herders should not be able to take eare of that herd at any time. Their nearness to Nome and Council markets is a great advantage to that herd. The sum total for which reindeer meat was sold from said herd during the past year exceeds $\$ 1,500$.

From Golofnin, Rock and I continued to Unalakleet, where we arrived on April 1, after forty-nine hours, traveling.

The Unalakleet herds have also done very well during the past year. During the time while Bals went with me to the Kuskokwim, Okitkon (Eskimo) had charge of the mission herd and did well. All the boys have done very well in their work and they are highly thought of by the chief herders. After the division of the herd last fall, the one of which Bals had eharge was driven to North River, some 6 to 10 miles up, while Bahr took his herd to the usual place on South River. At these respective places they have been kept until the first part of April, when they began to move toward the grounds for summer pasture. Ole Bahr had already begun to drive his herd toward Cape Denbigh when I returned from the north, so I met him with that

had to supply them with tent and food, etc., buying at Candle what we could not supply from our mission stock. Recent letters from Doctor Jackson speak of the probability of herd being established at Point Hope next season, so that these boys ean then return there.

With best wishes for the prosperity of your mission, I remain,

Most respectfully, your friend,

Dana Thomas.

UNALA KLEET, JURe 22, 1904.

Doctor JACkson: I inclose above letter of interest from Dana Thomas at Kotzebue. It is sad that so many fawns die, but I hope that the later fawns have been able to survive.

C. O. Lind. 
herd 16 or 18 miles north of Unalaklect. Bals was going toward the seashore about 6 miles north of Unalaklect village f'or the summer, and there he is now.

Although the herds have never been less than 1 s to 20 miles apart, the herders have had some trouble in keeping the deer from strolling from the one herd to the other. They have all had good pasture and no trouble with snow or any iey crust has been enconntered during the past winter. The fawns began to come on 1 pril 13. The weather was most beautiful, and the death rate among the fawn in both herds has been exceptionally low. Since some time before the fawning scason began the herds have never been alone. Two and sometimes three men have been watching by day and by night, so it is certain that no fawns have died from want of care on the herders' part.

The health among the herders has been most excellent the past year. Not only at Unalakleet, but at all the stations risited, the herders have been well and happy, with only one exception-John (Eskimo) at Golofnin, was suffering from pneumonia, and as it was his third attack he is naturally very much weakened and might not be al)le to stay with the herd and do as well as he at first promised.

The natives in general are quite well if we except the old chronic tubereular and rheumatic eases which are found in every village. Six deaths have taken place in our village of about, 300 inhabitants during the year, but in return we have been blessed with 16 births, and out of these 15 are living and thriving well.

Among the other improvements of the village we now have the pleasure of counting a new school building, for which the whole village population seems to be really thankful. Several natives who know Doctor Jackson have specially expressed their thanks to him because of all the interest he has shown for their advancement. In this connection allow me also to express our gratitude on behalf of the Unalakleet Mission for the assistance in getting that new and much-needed schoolhouse for the boys and for the medicines which were left for my use among the natives.

The Government buildings have been used but little the past year and are all in good repair. One of the eabins near the telecraph station was by my permission used by the Signal Corps men at the station as a store for their supplies a portion of the winter. The herders, when they come for their provisions, never care to stay in a room on that side the river, but they always go to some native to stay instead. One special trouble we have encountered the past year was at Eaton. As no one has been living there, travelers have been breaking in and made their home in the big building. After the first time I found it we left one small eabin open in which trarelers could stay if they wanted, but still they were not satisfied to leave the other building in peace. 
My experiences with reindeer during this year have been various and to my satisfaction. In my mind there is no doubt but that the deer industry will prove to be a permanent one in Alaska. It is the means by which our beloved Government has done and will do the natives of Alaska the most possible good. The herder is taught the practical lesson of helping himself. He does not live on charity; he works and earns his living, and is taught to depend more and more on his own resources. True, there are only a few as yet who have had the opportunity to get herds and to learn to take care of them, but when one stops to consider the short time the deer have been in Alaska an honest observer is forced to acknowledge great advancement.

It Unalakleet there are at present not less than 30 Eskimos who live wholly by the deer industry, and fully half that number who are indirectly benefited by their relatives having deer. At Golofnin there are 20 Eskimos who have their living directly from the herd at that place. And so it is wherever there are deer. Still, it seems to be the pleasure of some people to announce, not only as far as they themselves reach, but do it also throngh the agency of newspapers, that not one Eskimo gets his livelihood out of the deer, and that the deer prove to be a source of great expense and a waste of money, since they - the deer--are of no practical value. Of course, any sound-mincled person can reason that such statements are not true, but nevertheless they are bound to infuence the public to some extent, and for that reason I feel it my duty to prove by these statements of faets that such announcements are simply the productions of a few jealous and enrious ones. Many have not power of comprehension enough to counterbalance such false reports, but in their turn repeat and assure what they have heard as gospel truth.

Again, it is very common to hear that the reindeer are all right for the table, hut further than that they are of no value. Well, stop and consider the matter. There are many examples of the times of Mr. Kjellman and Doetor Gambell and others when the deer proved sufficiently well their utility to the public to establish for themselves a credit which justly belongs to them, but which they never received. Those things of the past are already on record for those who are earnestly seeking the truth to find it. But suffice it here to quote only my own experiences of the past winter. One trip, which demanded forty-five days for its accomplishment, was successfully done before Christmas. In all we traveled about 1,000 miles under adverse conditions, and 4 out of 7 deer made the return trip with us, hauling a load of from 100 to 200 pounds. If dogs should have gone that same way, they could not have hauled their own provision for the time and much less anything for their drivers. The deer hauled the whole load for the driver, its own provision being picked 
up by itself wherever and whenever we stop. No slecter is needed. When the most furious wind sweeps its path, the deer simply faces it with an open mouth and with an expression of satisfaction and joy. Another very practical feature with the deer is its inexpensiveness compared with other beasts of burden used and which are not adapted for the country. 'The cost price of a good dog is about as high as that of a good reindeer, but then for every day the dog is worked, or not worked, if he shall remain a good dog he will cost his owner 20 to 30 cents for food. Counting at 20 cents a day, which is cheap, the feed for one dog costs $\$ 73$ per year plus all the trouble, and then, at the best, the owner has only a d-o-g, which if he should need a piece of extra provision would afford very tough meat. Is soon as the wind blows a little, the dog can not travel; especially is this so if the wind happens to be in the face. The deer does not mind the wind in the least, from whatever direction it comes; it rather enjoys travelling against the wind. The deer never costs its owner 1 cent for feed. It causes much less trouble, and when it has served in hauling its master or his belongings it might serve as the greatest delicaey to satisfy his well-developed appetite.

As to the gentleness of the deer, let me state from my own experience that you can make it what you want it to be. Deer can do work which neither dogs nor horses can do, and mules, if they can do it at all, only under comparatively great expense. The have this winter been freighting 7 tous of goods from Fish River to Chicago Creek on the Kugruk River. On that distance the roud leads up a very hard river to travel, across three high and difficult mountain passes, the dreaded Death Valley and the valley of Koyok River, and down the Kugruk, a distance of 40 to 50 miles. On the road dogs are out of the question at once, because of the food, as they would have all they could do to haul their own provision. The horse would cost too nuteh and could not by any means stand the exposure. The mule would be impracticable also on account of its expense, and then the feet would not hold on the crusted snow on the divides; and where the trail is not solid it can do absolutely nothing. On the other hand, the deer need not laul 1 pound for itself; it costs nothing for feed; it faces all weather, and makes its way where the driver can hardly walk without snowshoes. It goes uphill and downhill alike. Trail or no trail, it will haul its 200 pouads or more day after day; yes, week after week. You might have to lay up for storms when you can not see where to gro or when you can not face the wind, but it can not be placed to the discredit of the deer.

After these simple facts are known, who is not able to see and understand that the deer is of value even to the white man who comes to Alaska. And if of value to him, how much more are they 
not worth to the people for whose special benefit and enlightenment our Government has placed these animals here?

I highly appreciate and wish to express my gratitude for everything done for my comfort and pleasure by the faithful workers at Bethel, Kuskokwim, Kotzebue, and Golofnin. I also wish to express my thanks to Mr. Karl J. Hendrickson, Unalakleet, for the many services rendered during my absence from home.

A. J. Bruner, attorney at law, Nome, Alaska, has, by his great services in so nobly and freely defending and freeing Mary Antisarlook, deserved not only my thanks but that of all who love liberty, truth, and justice.

Trusting and hoping for suceess in the noble work of educating the natives of Alaska, I remain,

Your obedient servant,

Dr. Sileldon Jackson, D. D.,

Carl O. Lind.

United States General Agent for Education in Alaska.

ANNUAL REPORTS, CAPE PRINCE OF WALES REINDEER STATION.

By Hugh J. Lee, in charge.

Wales, Alasisa, June 30, 1904.

Sir: The winter of $1903-4$ was a good one for the deer. From September 15 to Norember 15 the temperature was not above freezing nor below zero, and during the winter there was no weather warm enough to melt the snow, though the coldest was only $25^{\circ}$ below zero. The result was that there was no ice on the moss, so that the deer could obtain their food easily. There was very little snow until February and March, so that in the early part of the winter the deer did not have to dig for their food.

During the summer of 1903 some of the native herder's contracted to sell to the Government 168 female deer and to deliver them at the Teller reindeer station sometime during the winter.

In December the herder's began to prepare for the delivery of these deer, and started in by the hobbling method to separate them from the rest of the herd. This is the method often used in transferring them in the summer time. When about 40 of the deer were hobbled, the boys found that the feet on several of them were frozen on account of the stopping of the circulation, and they had to be killed; so they let the others go and came back and reported to me.

We had no corral into which to drive them for separating the herd, and I suggested making one with willows, but the boys said they had tried that in the past and the deer would break them down so that they could not be used. 
The boys suggested the postponement of the delivery nutil warm weather, hut I told them that we had agreed to deliver them during the winter and we must carry out our agreement.

They said the only way was to drive the whole herd to the Teller reindeer station, where they conld have the advice and assistance of the Laplander there, for the herder's at the cape have never lad the benefit of instruction from the Laplander, so that all they know of the deer business is what they lave picked up themselves. During my first season here a Lapp, who was married to a native woman, visited the village and spent a few days with the herders in the deer camp. The boys told me that they learned more about the deer in those few days than they ever knew before.

When we reached Teller with the herd it was in early February, and the Laplander showed the boys how to handle the deer and separate those to be sold from the rest. On account of storms this work took over two wecks, as they had to handle the deer very carefully on account of the danger of killing the unborn farns.

The $16 \mathrm{~S}$ were separated from the other's, but 2 escaped back into our herd and returned to the herding grounds, about 40 miles northeast from the cape. Those 2 deer are still in the herd, and 1 of them has given birth to a male fawn, so that we have those to be delivered with the others bought from the herd this summer.

On account of the lack of a corral I have never been able to enumerate the deer in the herd during my two years as superintendent, but I learned in Teller last winter that the herders there always make corrals of willows, and I contemplate making a corral in that way this fall and marking and enumerating the deer, for there are plenty of good willows at the winter feeding ground.

During the vear 66 of the mission deer have been slaughtered and 42 have died or been injured so that they had to be killed; also, $4 \mathrm{~s}$ of the deer belonging to the herder's have been slaughtered and 35 died or killed on account of injuries, making 191 deaths during the year, with 166 delivered in Teller, a decrease in the number of 357. and during the spring $37 \pm$ fawns were born.

Inclosed find a tabulated list of the owners and the number owned by each in this herd on June 30 , according to the tally liept in the herder's log book.

Dr. SHeldoN JACKSON,

Hegh LEE, Superintendent.

Washington, D. C.

Whates, Alaski, August 1, 1904.

SIR: I have spent the past week at the Cape reindere camp just south of Tin City. While there they strengthened the old corral, 
made of drift wood; marked 134 deer for the Bureau of Education; counted the herd; eut out and marked $39 \mathrm{~s}$ deer for the new herd at Shishmaref; and estimated the number of deer belonging to each individual herder. The fawns had not been marked for two seasons, and the 80 females sold by Stanley, 38 by Thomas, 33 by George, and 17 by James, which were sold to the Bureau of Edueation last February, were taken from the herd regardless of earmarks. This made it necessary for James, Frank, and myself to estimate the approximate number of deer each herder owned in the herd at present.

I inclose the tally of 1,391 deer we drove inside the corral and an estimate of the few deer outside.

On July 30 we took out of the main herd all the deer belonging to Thomas Sokweena, Joseph Enungwouk, Frank Iyatunguk, John Sinnok, Harry Karmun, and Walter Kiyuktuk, and sufficient number of mission deer to make a herd of 398. They plan to keep on the south side of Shishmaref Inlet this winter.

I purchased for the Bureau of Edueation 97 mission deer and 37 private deer. In marking these we used the aluminum button markers you mailed me. We are all well pleased with them. They are especially suitable for marking a Government or mission herd, as they do not mutilate the ear so as to prevent re-marking with an earmark when given out to apprentices. The earmarks, we think, are preferable for the individual herder. They enable them to recognize the deer without roping them. This ear marking is too often done irregularly, carelessly, with a sheath knife. Montgomery Ward \& Co., Chicago, have a cattle punch whieh I think would answer admirably. By using half of dies Nos. 1, 4, 5, and 6 in the inclosed deseription a great variety of regular earmarks could be made. Holes punched or cut through the ears of deer generally tear out and can not be reeognized without roping the deer.

The importance of the midway relay stations or herds between Kotzebue and Barrow, which you speak of in your letter of June 28, ean hardly be overestinated. I hope your plans in this direetion ean all be carried out this winter. In no other way can we have a satisfaetory and speedy reindeer mail service. In this conneetion I wish to emphasize the importance of the Government eneouraging the training of more sled deer by the Eskimo herders. This might be done by offering a price ranging from $\$ 45$ to $\$ 60$, according to age, size, speed, etc., for well-broken deer.

I suppose Doctor Hamilton will be able to give me much information in regard to the work you have planned, which you have not been able to give by mail. I am anxiously awaiting his arrival.

The schooner Fortuna arrived here July 15 and finished discharging July 21. The new building is almost sheathed all over and roof 
partially shingled. We had the assistance of Mr. Olson until July 30, when he had to go to 'Tin City to join the selooner Laura Mradsen, bound for Kotzebue and northern points. We are using \& native workmen now and can probably use more in a few days. Mr. Evans seems to have everything well in hand and is griving all his time in directing the work.

The Fortuna is now at Tin City discharging. The Laura Madsen sailed for Kotzeloue last night. 'The Thetis has been reported as having reached Nome, and will no doubt be here in a few days. 'This will enable me to reach Point Hope as soon or most likely before the Madsen. The Madsen has a $\$ 5,000$ outfit to discharge at Cooper whaling station before landing the schoolhouse.

I have been recently told that there is a chance to have the Nome-Kotzebue mail come via Wales. The herlers here could handle such a route to advantage. We have heen orer the route and know what it is. They could place relay sled deer, or two more herds, along the route and arrange for a quick service. By the use of relay deer they could make the trip from Wales to Deering in four days if necessary. If you can give them any information or suggestions in regard to securing contract for such a route it will he appreciated.

The route from Teller to Wales is better adapted lor dogs than deer most of the winter, but the Eskinno boy Sarilook made a splendid record with deer on this route last winter.

A canoe load of Shishmaref natives are here at the cape trading. They are very anxious to have you give them a school next year. The name of their settlement is Keviktuk. If a school is put there they say some of the families living just north and south of there a few miles will move in. I think it a splendid loeation for a school and hope you can put one there next season. I shall investigate it more fully this winter.

Hoping to hear from you as often as possible, I am, very truly, yours,

Dr. SHELDON JACKSON, IV. T. LOPP.

General Agent of Education in Alaska, Washington, D.C.

REPORT OF W. T, LOPP, SUPERINTENISENT OF REINDEER STATIONS AN1) SCIOOLS IN NORTIIWESTERA ALASKA.

WALEs, Ilaski, October 11, 1904.

SIR: As we have but one more chance to send mail, I will now try to give you a brief general report of the summer's work.

On June 4 Mr. A. N. Evans, teacher for Wales, and I left Seattle on the splendid steaner Fictoria, and arrived at Nome June 12. Three days later, we left Nome on the gasoline schooner Augusta $C$. for Cape Prince of Tiales and way points. Our two days experience sleeping on sarcis of potatoes in the hold of this small, frail craft,

S. Doc. (i1, 58-3) 
bumping and jarring through the ice, with a can of meat, bread, and black tea, served occasionally on a small improvised table, furnished with one knife and fork and spoon, all served to remind us that we were now entering the Arctic life, where, as Captain Jarvis says, "If you are subject to miserable discomforts, or even if you suffer, it must be regarded as all right and simply a part of the life." As for myself, the anticipation of giving the Cape Eskimos a complete surprise helped me to forget my own discomforts.

On June 18, about 1 a. m., just as the midnight sun had risen above the horizon in the north, we rounded the cape and came within sight of the village. The shout of $\mathrm{Ta}$ rah me! Ta rah me! (a ship! a ship') which went up from the people among whom I had spent ten years, caused me to tremble with excitement. By the time we were anchored, canoes were alongside of us and we were kept busy shaking hands.

Upon reaching shore we found that civilized food was scarce in the village. Walrus steak, seal liver, whale skin, ducks, and other Arctic luxuries made up the principal part of our bill of fare for a few days until we could go to York and get supplies.

Before the arrival of the school building on the schooner Fortuna, July 15, I was able, by traveling 230 miles in canoe, to visit the Port Clarence herd once and the Cape herd twice.

Mr. Olsen, the carpenter for Barrow, etc., arrived here June 27, and Mr. Alseth and his assistant, Mr. Finley, on July 6. Previous to their arrival and the mail with the invoice of the lumber and building material, Mr. Evans and I had considered the advisability of making two houses of the building-the schoolhouse near the old mission school building and the residence in the north end of the village. After estimating the additional lumber required for such a change we concluded to make no changes in the original plan of the building.

Just before leaving Seattle I received an urgent request from the American Missionary Association asking me to look after the management of their herd and herders at this place. On July 9 I took charge of the herd and divided my time between the herd and school building until the arrival of the Thetis. After repairing the corral, built just south of Tin City in the summer of 1900, we marked 134 deer purchased for the Bureau of Education, counted the entire herd $(1,488)$, "cut out" and marked a herd of 398 for Shishmaref Inlet, and marked the big herd remaining.

As but little or no marking or castrating had been done for two years, this prolonged and continued handling in the corral materially told on the condition of the herd. In "roping" the deer some of the fawns were brained. The lasso accidentally jerked a young horn off and a piece of skull 2 inches in diameter with it. These had to be 
killed. Most of them happened to be male lawns. Their slins were prime lor winter clothing and their meat was marketed at York for 25 cents per pound. Before leaving the reindece (am) I ardvised the herders, as an experiment, to castrate about 20 fawns during the summer. 'The Lapp and Siberian custom is to wait until they are 1, 2, and 3 years old. I know of no good reason why we can not follow the practices of stocknen in the States in regard to this, espereially because reindeer mature so young. Most of the yearlings have fawns.

The supply schooner Viling got on the Cape Prince of Wales shoal here on the evening of $\mathrm{August} 4$ and canc ashore a total wreck. With the exception of a few staples like sugar and beans, suflicient supplies were saved to supply the necessary wants at the Cape.

On August 6 the United States revenue cutter Thetis, Cajt. O. C. Inamlet commanding, made a hurried stop here, and I madr a hasty departure for the northern points in my district, a trip of seventeon days. With Captain Hamlet as host, and Mr. and Mrs. Kilbuck, Messrs. Collier, Washburn, and Hutchinson, of the United States Geological Survey, and Doctor Driggs as fellow-sharers in his hospitality, my time aboard was spent most pleasantly.

On the night of August 7 we came to anchor ofl Cooper Whaling station at Point Hope. On the following moming, in company with Surgeon Call, I visited the whaling stations and the settlenent surrounding them, and was informed that there was a school population in that vicinity of 30 to 40 . The selected a good location for the building near the stations, in case it should be decided to locate the building so far from the Point Hope settlement. Walking down the beach to Point Hope proper, we visited the mission and the Point settlement and returned aboard about ? p. n1. Doctor Driegs, of the St. Thomas Mission, seemed to think that their board could he depended upon to look after the educational wants of the fast diminishing Point Hope settlement. As the ship was getting under way, I sent letters of instruction ashore by natives to $\mathrm{Mr}$. Olsen, the carpenter, and Mr. Ilenry Konig, better known as "Cooper," to have the house landed at the site we had selected near the whaling stations.

On the night of August 10 we reached Point Barrow. 'The whaler's were all anchored or tied up to the ice waiting for an off shores wind to make a passage for them alound the Point. Rev. S. R. Spriggs and Doctor Marsh came aboard about michight and got their mail. On the following morning 1 accompanied Mr. and Mrs. Kilbuck ashore in a skin boat. We found them all husy at the mission reading or answering their mail. We looked over the ground for a suitable site for the new school building. Mr. Spriges accompanied me aboard about noon and the (aptain kindly steamed down the coast

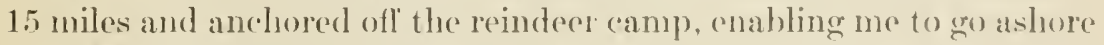
with Mr. Spriggs and his herders to see the hered. The deer looked 
very well. On account of having so large a proportion of spotted and white deer, it was the most beautiful herd I had ever seen. When the Cape and Symrok herds were selected from the Government herd at the Teller station in 1894 the herders naturally selected all the spotted deer they could get. Likewise when parts of these same herds were returned from Barrow in 1S99-1900 the herders at that place chose to keep the spotted and white deer there. The deer born in this northern latitude seemed to be considerably smaller than those born farther south. Before returning aboard a few deer were "roped" and some milk obtained for the captain's mess.

After returning aboard from the herd the ship proceeded to get underway. As we bade Mr. Spriggs farewell we could but appreciate the fact that his courtesy in accompanying us to the herd must now cost him a 15-mile walk home, facing a bracing wind.

On the following morning (August 12) we anchored off Wrainwright Inlet or Point Collie. Repeated blasts from the ship's whistle failed to bring any natives ofi. They probably considered the wind too high. Only 2 tents and 5 deserted winter igloos were visible.

Our next stop was at the coal mines near Cape Lisburne to pick up the United States Geologieal Survey party.

On the evening of the 13 th we came to anchor off Cooper station, where the schooner Laura Madsen was discharging lumber and supplies for the school building. Finding that the windows, doors, hardware, and lumber could not he properly or safely cared for without a temporary building, we concluded to put up the frame and outside of the school building. Captain Hamlet kindly offered me an officer and 5 men, including one of the ship's erew who had been acting as carpenter since leaving Honolulu. We found a very fair carpenter on shore in the person of Mr. George Marlen. We employed him and Mr. A. J. Allen and Joseph Frairo to assist on the building. Lieutenant Shoemaker volunteered to go ashore and take charge of work until the cutter should return from Liotzebue.

Dr. John B. Driggs came aboard here to go to Kotzebue. The doctor eame to Point Hope fourteen years ago, and was now going outside for his second yearly vacation.

We anchored off the Kewalik, on southeast side of Kotzebue Sound, on the afternoon of August 16. Here United States Commissioner Bosqui, who had been the guest of the ward room since leaving Nome, and Doctor Driggs were transferreci to the coasting steamer Corwin.

On the 17 th the vessel steamed abont 15 miles to the westward and anchored off Alder Creek to water ship. In order to save time while the ship was taking water, I took passage that same evening on the Saidie for the Kotzebue Mission, where I had a very pleasant two-day visit with Mr. and Mrs. Thomas and their people. The lrerd was 50 or 60 miles away, so I was unable to visit it. Mrs. Thomas 
had a very interesting summer school for the river liskimos who were camped on the fishing grounds about the mission for the summer.

On the 19th the Thetis got underway for Point Ilope and came to anchor off Cooper's Station about '2 p. m. the following day, making three consecutive Saturdays the cutter had anchored at this place.

Lieutenant Shoemaker and his crew had made a grood showing. They had the frame of the building up and ready lor the rafters. No work was done on the building Sunday, hut on Monday ('aptain Manlet sent extra men ashore and considerahle showing was made nailing on outside sheathing, the ceiling joists over the schoolroom, and sawing the rafters. A fierce, raw wind was blowing, so no attempt was made to nail the rafters in position. Lientenant Shoemaker reported that Mr. Marlen was a very fair carpenter, so before leaving we arranged with him and Mr. Konig to eomplete the frame and outside of the building and store the lumber and hardware inside of it.

On the evening of August 23 we anchored at Cape Prince of Wales. Here Mr. Collier and his assistants, Messrs. Washburn and Hutchinson, and myself left the eutter, and Doetor and Mrs. Campbell, who had been making a summer visit at the Cape, came aboard to return to their home on St. Lawrence Island.

Since returning here I have put in the time assisting in the work at this station. The new building is almost ready to ocerupy; the paint is almost dry; the benches are being put down, and we hope to have school open next Monday, Oetober 17. We have had a season of stormy weather for the past two weeks. Sixteen canoes have not returned yet, but most of them will probably arrive before the opening of school, so that Mr. Evans can begin with a full school.

The natives who have returned from Nome think our new building is much nicer than any house they saw there. The old mission building, which eost the American Missionary Association \$:3,000, now looks like a "shack." Mrr. Evans is planning to have a "housewarming," or ah va pa le za uk tuk, as the natives call it, one night this week.

Last week I plamed to go either to Kotzebue or Port ('larenec, but the weather prevented my going either north or south. It now looks as if navigation is about closed and that in the future I shall have to travel by sled.

As needed changes suggest themselves to me, I shall write you from time to time in regard to them. Hoping to hear from you of ten this winter, I am,

$$
\begin{aligned}
& \text { Very truly, yours, T. Lore, } \\
& \text { Superintendent of Reindeer Stations and Schools } \\
& \text { in Northuest Ilaska. }
\end{aligned}
$$

Dr. Sheldon Jackson, General Agent of Education in Alaska, Wastington, I. C. 


\section{ANNUAL REPORT GOLOFNIN REINDEER STATION.}

By O.P. ANDerson, in charge.

Dear SIR: I have the honor to submit the following report of the reindeer station at Golofnin:

The herders are Nils Klemetsen and wife, Tautook, wife and two apprentices, Amahktoolik and Simon.

Constantine with Lowry, apprentice, Taktuk with family, and IIarold, an apprentice.

The mission apprentices are John Pomerstchuk, Albert Angotok, and Benjamin. These are now all married, and have gotten their wives from the orphanage. They have all been in good health, with the exception of John, who was sick last winter for some tine.

The herd is doing well. There are of course some deaths from different causes, both external and internal, and from accidents. We have sold some for the meat market, both at Nome and at Council, and I have given the herders a chance to sell some deer to pay their provision.

Last winter we had a contract of freighting some goods into the luachuck with reindeer from our herd and from the herd at Unatlakleet. Although they were met with the most severe snowstorm of the season, they made it a suecess. This proves that the reindeer can do a great service where horses and dogs can not be used. This might open a field of transportation with the deer in years to come.

The worst enemy to the reindeer industry is the fire caused by careless miners going through the country. We have been fighting this enemy for two weeks this summer. It has been very dry, and the moss has burned like powder, and before the storm it swept the mountains very fast. A good rain came to our assistance and made an end to it.

Mr. Klemetsen has marked 19 female deer with the Government mark, for provision gotten through A. E. Karlsen. Tautook has done the same with two female deer for provision gotten at Unalakleet.

$\Lambda$ the orphanage we are all well. We had 35 children in the home last winter and during the school year. The school is growing every year, and it is in need of sehool benches. The teacher will be disappointed if the benches do not come this summer.

A new teacher has been sent up here by the board of the missions. Her name is Anna Hagberg, from Chicago, Ill. She has studied at North Park College.

My wife, who has been teaching school for five years, will now devote her time to the home and the mission work.

Best greeting from us all.

Yours, truly,

O. P. Anderson.

Dr. Sileldon Jackson,

General Agent of Education in Alaska, Washington, D. C. 
ANNUAL REPORT BETHEL, REINIEER STATION.

Bethel, Alaska, July $26,1904$.

Dean Sir: Since I wrote to you from the ship about the arrival of the Finns, I have received your letter of $\Lambda$ pril 22, announcing the coming of Mr. II. E. Redmyer.

We arrived at Bethel July 22 with all the Finns, but could not take all our provisions at once, therefore I sent the Finns down to Quiuhagak for the second load (with some natives), and then I will give them their provisions and take them to the deer. Mr. Karbum has 5 children, and we think it impossible that they ean all go to Copper Center in winter. Their children have been born in the States and have not even seen deer; traveling just in the coldest time of the year is too dangerous for them. I have made arrangements lor them to stay here orer winter. If the Government pays for rent, stove, and wood, the other things Mr. Karbum will pay from his salary.

Next year we ean either send them out to Valdes, or Mr. Karbum can come back and stay on the Kuskokwim. I will wait for your directions.

The men like Alaska very much--coming up the river, seeing the many places with so much grass. Oh! they just wanted some cows and start right in here. It is just like Finland, they always say.

Now, with the Lord's help, we will do all we ean to get them to the deer and start them for Copper Center.

From our deer I can give encouraging news. They have increased to 500 .

\begin{tabular}{|c|c|c|c|}
\hline & Fawns. & Male. & Female. \\
\hline $\begin{array}{l}\text { IIerd } \\
\text { Mr. Spein } \\
\text { Mr. Sara. }\end{array}$ & $\begin{array}{r}154 \\
79 \\
91\end{array}$ & $\begin{array}{l}46 \\
4 \\
47\end{array}$ & $\begin{array}{r}48 \\
a 35 \\
a, 44 \\
b .4\end{array}$ \\
\hline
\end{tabular}

"13 dearl.

b.11 dead.

How many of these fawns belong to the native herders I could not learn.

I thank you very much for the reading matter and school supplies. The latter is needed and the former always very woleome. Mr. Joaquin will go to the Yukon to-morrow and take our mail along. I close now with all good wishes to you, and renain,

Yours, truly,

Rev. Doctor J⿳⺈冂大son,

Anolf Stecker, Superintendent.

Wastington, D.C.

Two of the Finns have asked you to have some of their pay sent to their lamilies in Michigan. I hope that can be done, as they are anxious to help their families. 
ANNUAL REPORT KO'TZEBUE REINDEER STATION.

By Dana Thomas.

Kotzebue, Alaska, July 1, 1904.

Dear Sir: I herewith transmit to you my annual report as superintendent of Kotzebue reindeer station for year ending June 30, 1904.

The past season has been a prosperous one with us. Very little extremely cold weather and light snowfall; as a result we have only lost about 7 per cent of this year's fawns, as against 20 per cent last season. In midwinter we were given the pleasure of a visit from Doctor Lind, supervisor of reindeer in Alaska. He inspected our herd and reported the same in "best possible condition."

The early coming of the cold last October and the freezing-in near month of Kowak River of the river steamer John Riley with a number of people on board, gave us an opportunity to sell a number of male deer belonging to mission and Nilima. A few were used for meat, but the majority were desired as sled animals. Although our supply of latter animals was limited, and we could easily have sold double the number that were available, we did not increase the price, but sold all of them for the price quoted previous to the cold weather. Without a single exception, all of the purchasers of deer were satisfied with them. One man took 800 pounds of supplies 200 miles up Kowak River, helping the deer over the hardest places in the trail, sold a portion of supplies at Riley Camp, and freighted balance over divide to Koyukuk River; after reaching there sold his deer for $\$ 35$ more than he paid for it at the mission.

The use of deer as sled and pack animals is greatly growing in favor among mining men, and the only eriticisms from anyone come from the danger of deer being killed by dogs. That objection will be removed within a few years, when the country will be stocked with sufficient deer to enable everyone to dispense with dogs as beasts of burden. Personally I was not particularly enthusiastic over the reindeer when I first landed here two years ago, but I am "wiser to-day than yesterday," and have not the slightest doubt now but that the introduction of domestic reindeer into Alaska will, within a few years, be the main source of the greatest good to not only the natives but the whites as well. I venture the assertion that the reindeer will in the near future bring more wealth and happiness to the people of this district than all the gold and silver that is delivered from Alaskan mines.

Inclosed find table showing ownership of reindeer in my care at this date.

Most respectfully,

Dana Thomas.

Dr. Sheldon JACKson,

General Agent of Education in Alaska, Washington, D.C. 
REINDEER ANI) ( IRIBOU.

By C. C. Georciesox, M. S.

Special agent in charge of Alasku Agricultural Experiment stations, Office of Experiment Stations.

[Reprint from Agricultural lieport.]

The reindeer of Europe and Asia and the caribou of America are usually considered to belong to one and the same species, Rangifor tarandus, though some distinguished seientists reeograize seven different species. For the purposes of this article they may be considered as one.

\section{GEOGRAPIICAL IHSTRIBITION.}

The reindeer constitutes one of the sevoral genera into which the deer family is divided, and, considered from the standpoint of its usefulness to man, it is by far the most important mrember of this family. Its range in the wild state, though extensive, is confined to northern latitudes. On the American continent it is found from the shores of the Aretic Ocean along the Alaskan range, even below the boundary of the Inited states in the west, and in the east through Labrador to New Brunswick and Newfoundland, while on the plains it does not reach down so far. In Newfoundland, which is as yet but thinly settled, and the settlements located chiefly in the south and southeast portion of the island, there are still large herds of caribou, which feed in summer on the barren highlands of the north and in winter migrate to the wooded districts in the south. Caribou, it is reported, are likewise still found in the hilly districts of New Brunswick and adjoining distriets. In the interior of Alaska caribou is the most important game animal, though it is rapidly disappearing from the regions most frequented by the prospector and miner. In the Kenai Peninsula caribou are still found, but they are searce. Its ramere is here almost identical with that of the moose. Both oceupy the woods in winter and in summer both seek relief from mosquitoes by going to open ground, the caribou secking the mountains, while the moose is more inclined to go to the errassy meadows along the seacoast to escape the pest. In the interior of Alaska there are still large regions umexploited where earibou are found in numbers, but they are scaree along the trails. In fact, they are nowhere numerous, except in the foothills of the range in which Mount MeKinley is the prineipal peak. Small herds are seattered all through the northerm plains of the continent to the Arctic Ocean.

In Europe it is found in the northern parts of Norway, Sweden, and Russia in the same regions as the domestic reindeer. In the sieandinavian range it extends well down toward the south, and in Russia it is said to be found throughout the whole length of the Ural Mountains, but not in the Caucasus. It is likewise found throughout the 
whole of northern Siberia and in the mountains as far south as latitude $52^{\circ}$. Reindeer are especially numerous in eastern Sibcria, in Kamchatka, and in the region bordered by the Sea of Okhotsk, where they are largely domesticated. They have been imported into Iceland, where they have escaped from domestication and now run wild in great herds. They are found in Greenland, and, more wonderful still, in Spitzbergen, a group of islands in the Aretic Ocean nearly 400 miles north of Norway, stretching from latitude $76^{\circ} 30^{\prime}$ to $80^{\circ} 30^{\prime}$. sportsmen have killed reindeer there by the thousand. This is, of course, a long way north of the northern limit of tree growth. The forest of more southern latitudes is here represented only by willows a fow inches high. There are some flowering plants, but the principal vegetation consists of mosses and lichen, on which the reindeer feed. In short, the range of the reindecr and caribou is bounded by the isothermal line which determines the character of the vegetation on which they feed. They apparently prefer a species of lichen (Cladoniu rangiferina), which for this reason is commonly called "reindeer moss," hut they eat also other eryptogams, and they are very fond of mushrooms. In summer they browse much on willows and other brush, as well as grass.

In a former epoch the reindeer inhabited all of Europe, even down to the Mediterranean, having apparently been driven south by the advancing ice. Its remains have been found in France and elsewhere in continental Europe and in Scotland and in Ireland.

\section{TWO RACES OF CARIBOU.}

It may be noted here that in America there are two races of the caribou, commonly namerl after the range they occupy. One is called the Woodland caribou, and occupies the southern limit of the range; it feeds largely on grasses, and migrates southward in summer. The other, which is known as the Barren Ground caribou, follows the receding cold weather to the northward in summer, and goes to the woods, when it goes there at all, only in winter. The two differ in size, the northren type being the larger; they differ also in the antlers, which in the northern type are more palmated - that is, flattenedthan in the southern type. These and other slight differences may be sufficient to separate the species - they are certainly varieties; but it is worth noting that no one thinks of erecting new species among our domestic cattle. And yet there are more marked differences between a Jersey and a Galloway, for instance, or a Merino sheep and a Blackfaced Seoteh, or between a racer and a Shire horse, than between these groups of the reindeer. 


\section{IESCRIITION.}

Reindere vary much in size. In athumlant food supply is an important lactor in their development, as in the case of other animals. Again, breed-perhaps we should call it race- charactoristics are another factor influcucing size. In some portions of Siberia the roindeer is much larerer than in I aplanel. Some domestic derer in that region stand 5 foet hight, can carry 200 pounds on their hackis, and are quite grenerally used for riding. There is more variation in size among the wild deer than among domesticated ones, the larerest being found among the former; but, on the other liand, taking a large number, the domesticated deer will average larger than the wild.

Compared with other members of the deer tribe, it is not a graceful animal. The head is large, muzzle broad, neck short, set low, and usually earried horizontally. When the animal walks the top line of the neck is below that of the back. The withers are high, reaching above the line of the back; shoulders rather heary, with prominent shoulder points, though when the animal is in good condition they blend pretty well with the thick hase of the neck. The laack is narrow, rump sloping: hind quarters light; flank low and quite full: underline nearly parallel with the back. In the fawns the legs seem disproportionately long, hut in the mature animal ther appear, on the contrary, rather short: the forelegs are straight, but the hind legs are crooked and spreading outward from the hock as if to brace the hind quarters and prevent their wabbling sidewise. The feet are large, and the hoofs spread when pressed against the ground-a provision of nature which aids the animal to get over soft snow or mud.

In color the caribou is gravish brown, larker in summer, lighter in winter; and while this, too, is the prevailing color of the domestic reindeer, the latter vary more than the wild ones, some being spotted, others almost white. All are lighter on neck, shoulkers, and belly than on the back. The coat is exceedingly thick, Ionger in winter than in summer, and under the neck the hair is some 5 or 6 inches long, but there is no mossy undereoat such as most animals indigenous to aretic latitudes have. One peculiarity of the hair of the Naskan earibon is perhaps worth mentioning, as I have not seen it referred to elsewhere, and that is that most of the hairs are more or less flattened, not eylindrical; the cross section is oblong. and in some eases they are as much as three times hroader than thick. Moreover, the individual hairs are sinuous, the wave lines being on the edges of the hair, so that they do not appear wary when riewed on the edge. The hair is exceedingly brittle and hreaks ofl' readily when handled. For this reason earibou and reindecr skims do not make good rugs. They litter the floor continually with broken 
hair. The summer skins are better in this respect than the winter skins. The hide is thick and impervious to water to a marked degree, and by a certain mode of tamming practiced by the Lapps it can be made perfectly impervious. On the face and lower part of the legs the skin is particularly thick and durable, for which reason the Lapps use these portions for footwear.

A unique eharacteristic of the species is that both males and females have horns or antlers. They shed them annually in Marel and April, after which a new pair immediately start to grow. The young animal has cylindrical horns-nearly straight- which grow to a foot or more in length the first summer, but as it grows older the borns become palmated and curve outward and backward, and prongs, or branches, increase in number annually up to the age of seven or eight years. From that time the prongs decrease in number until in old animals there may be only a few points on the outer ends of the horns. In the prime of life one or both horns produce prongs which reach down over the face, called "brow antlers." The size of the antlers varies with the size of the animal. Antlers of females are smaller than those of males. Occasionally a pair of antlers is found measuring 4 feet in length and weighing as much as 40 pounds, but this is extreme; half of these figures more nearly represents the average. It is not easy to see just what function they fulfill in the animal economy. They appear to be a hindrance rather than a help in the struggele for existence. It must be a vast drain on the system to furnish nourishment for their rapid and prodigious growth, and they are tender and of little use for defense during the summer months while growing. They are at this season covered with skin, which is abundantly supplied with blood ressels and a fine coat of hair, when they are technically said to be "in the velvet." They are full grown about the time the breeding season begins in the fall of the year, and then the bulls use them freely on each other, but otherwise they are not often used for either defense or offense; instead, they strike their antagonist with their fore feet. The horn is soft, spongy, and not strong. Nor does the animal use the antlers in digging away the snow to reach the moss underneath, according to the observations of reindeer berders and others; this is done with the feet and nose.

The writer has not learned if any of the modem dehorning fluids have been used to suppress the growth of horns on domestic reindeer, but it would appear to be a subject worth experimentation. So far as known, the natural life of the caribou is about fourteen years, as is also the case with the reindeer. It does not reach its prime until six or seven years old. 


\section{DOMESTIC REINDEER.}

We have no means of knowing when reindeer were first caught and tamed by savage man. They wore doubdess first captured and confined with a view to having a food supply handy. Later he also found that his fleet-footed captive could be made to draw him over the snow, and this is as far as he las reached to-day. They have been domesticated for ages by the Laplanders, or rather by that portion of them who live a nomadic life, for most of the lapps are fishermen and farmers. The reindeer is also domesticated by the Mongol tribes of Siberia, but to what extent is not fully known. It is known, however, that individual owners in that region hold herds of 15,000 animals or even more. One interesting feature of the deer in that region is that certain breeds or races of them are larger and much more powerful than the Lapland deer, and, in consecfuence, are of greater service to man. This is especially true of the breed of deer kept by the Tumguse tribe in eastern Siberia. It was to introduce these large deer into Alaska that Lieut. E. P. Bertholf, of the lnited States Revenue-Cutter Service, visited Sibcria in 1901, and, as we shall'see, succeeded in landing about 250 head of thom at Port Clarence.

The reindeer people, whether they live in Lapland or in Siberia, are all nomadic. 'They have to be. The deer, which live in large herds, must be moved from place to place in search of pasture. The people consequently have no fixed abode, but live in tents, both winter and summer. They take the reindecr to the woods in winter and drive them to the mountains and open tundra in summer. Some of the people have log houses for winter use, located at various points on the range; others live in tents always. This is, of course, not conducive to a high state of civilization. Herding decr is in most respects like herding sheep. They must be kept together to prevent their straying off and becoming lost; they must be protected from wolves and other predaceous animals, and the sick ones and the fawns must be looked after. In return for this ('are the reindeer supplies nearly all the frugal wants of its owner. The meat is his chief food; from the milk he makes cheese, or, in winter, he kceps it in frozen chunks for use in coffee or for cooking, or it is evaporated and kept that way, or it is made into butter; the blood is saved and eaten; the fat is used for food, for candles, and for making footwear and clothing waterproof; the skins are used for tents, for clothing, for mats and blankets, for boots, for lassos, for straps, and for thongs; the bones and horns are used for tools and utensils and, togrether with the hoofs, are used in boiling glue; and the animals are his burden bearers and motive power while they live. By the aid of the reindeer their owners maintain an existence where they otherwise would starve. 


\section{REINDEER IN ALASKA.}

The name of Dr. Sheldon Jackson is inseparably connected with the introduction of reindeer in Alaska. It was due to his initiative that the work was begun and it is due to his persistent, unflagging efforts that it has been continued. When he first began, his efforts were greeted with scoffing and ridicule. Elaborate arguments were advanced to prove that reindeer could not thrive in Alaska and that the attempt must end in certain and disgraceful failure. But he followed his plans undismayed. He succeeded at length in convineing Congress that it was the cheapest and easiest way of preventing the starvation of some thousands of Eskimos. Now the work has advanced so far as to prove beyond peradventure that reindeer will thrive in Alaska. The Eskimos are learning to handle them; the herds located in various places in the Territory are increasing fast; the white people who have seen the progress of the work have learned to appreciate the deer, and the voice of the scoffer is now but seldom heard. Some day a momument will be erected to Dr. Sheldon Jackson to commemorate this feature of his work and the benefits he thereby conferred on the natives.

The story of their introduction is most interesting. I will briefly note the salient points, derived chiefly from Doctor Jackson's reports on the subject.

Doctor Jackson visited aretic Alaska in 1890 for the purpose of establishing schools, a task which had been assigned to him by the Commissioner of Education. He found the Eskimos more in need of food than of schools. They were slowly dying of starvation and disease. Their condition had been changed for the worse by the influx of the white man. The relentless hunt of the whale and the walrus in steam ressels had largely reduced the number of these animals, or else they were driven beyond the reach of these poor people with the appliances at their command to pursue them. Thus their main food supply was lost. The fur animals had been hunted until well nigh exterminated, and the Eskimo could obtain but few furs to barter for food. The wild caribou, or reindeer, which had roamed over the tundra, were also killed off or driven away. Add to this the corrupting influence of the introduction of intoxicants and the vices of the white man, and it will be seen that their condition was pitiable.

In casting about for means to help them, it occurred to Doctor Jackson that the introduction of the reindeer would meet their wants. So soon as the deer were sufficiently numerous it would give them a permanent food supply and forever settle the question of starvation. He realized also that there were many and formidable obstacles to such a scheme. It was a task that it would take many years to accomplish, and the Government and people must be converted to the plan before it could be undertaken at all; and it meant that the 
modes of life of the Eskimos must be changed to some degree from a hunting to a pastoral life.

On his return to Washington he advocated an appropriation by Congress for the purpose of purchasing reindeer in siberia and transporting them to Alaska. The proposition was new; it took time to convinee Congress of the practicalility of the plan, and the first bills to that end failed to pass. Neanwhile Doctor Jackson, firm in his conviction, and with the approval of the Commissioner of Education, to whom likewise much eredit is due for his cordial cooperation, appealed to the public through the press--described the condition of the Eskimo people and asked the aid of eharitable persons to inaugurate his scheme. "The response was prompt and generous." $\mathrm{He}$ received something over $\$ 2,000$, and by the aid of a revenue cutter in arctic waters, assigned by the Secretary of the Treasury to transport the deer, he proceeded to procure the first reindeer from the semisavage tribes in Siberia.

This first importation consisted of only 16 head. They were landed in Unalaska in the autumn of 1891. During the summer of 1592 he made five visits to Siberia and purchased and imported 171 head of reindeer. These were landed at Port Clarence, where, on the 29th of June in the same year, an institution for their breeding was established and named after IJon. II. M. Teller, Senator from Colorado, who had taken much interest in the enterprise.

In 1893 Doctor Jackson purchased in Siberia and added to the Alaska herd 127 deer, and 79 fawns were born to the herd already imported. In the same year Congress made the first appropriation for this work " $\$ 6,000$, to be expended under the direetion of the Secretary of the Interior, for the purpose of introducing and maintaining in the Territory of Alaska reindeer for clomestic purposes." Siberian herders were employed at first, but it was soon realized that the Lapps were the best teachers for the Eskimos, and so in 1894 seven Lapp herders were brought over from Norway. For their traveling expenses Doctor Jackson again had to call upon private beneficence. He also hired a superintendent of the work, Mr. W. A. Kjellmann, who proved himself most efficient. The work was now fairly started, and Congress increased the appropriations.

In the meantime there was a steady progress in the growth of the herd. Some importations were made every year, except in 1 s! 96 and 1897 . The average increase in the herd for ten years has been 42 per cent. This is not the percentage of the fawns born, but the percentage of fawns which lived through the year in which they were borll.

This ineludes, among the killed for the year 1597, $1 \triangleleft 0$ deer driven to Point Barrow to feed the starving whalemen and 66 which were lost or killed on the way up there. I regret that I have no later dista 
at my disposal; but from the above it seems safe to assume that on the 1st of October, 1903, there were 7,000 reindeer in Alaska. This is a remarkably successful showing; and even if no more were introduced, Alaska could be stocked from the present herds. At a rate of 40 per cent annual inerease there would by 1910 be upward of 70,000 reindeer in Alaska. It is probable, however, that there will be a greater pereentage of losses as the number increases for the reason that they must be seattered more and more among the inexperienced natives, who can not give them the same care they have so far had under Govermment supervision, and, with the increase, more will probably also be slaughtered for food. There should be no cessation in the importations for several years to come. It will take many years under the most favorable circumstances to fill the territory with all it can support. Doctor Jackson estimates in his report for 1895 that there are 14,000 square miles of deer pasture in Lapland, and that there are 23 reindeer to the square mile. On the same basis he also estimates that it will require $9,000,000$ head to stock Alaska. Of course, this is only tentative. Lapland is more densely populated than Alaska is ever likely to be, and fewer deer will supply the wants of the people of Alaska.

\section{PRACTICAL, TESTS.}

The first notable example of the endurance of reindeer in Alaska and their adaptability to winter travel was a trip made in the winter of 1896-97 by W. A. Kjellmann while he was superintendent of the Teller reindeer station. He left Port Clarence in the middle of December, 1896, and traveled southward to the Kuskokwim River, about 1,000 miles distant, and returned to the station April 25, having accomplished 2,000 miles through a rough and barren country, in the worst season of the year, the reindeer obtaining their living from the moss which they dug out from under the snow.

The second practical demonstration of the value of reindeer was made in the winter of $1897-98$, when a relief expedition in charge of Lieut. D. H. Jarvis, of the Revenue-Cutter Service, was sent overland to the shipwrecked whalers at Point Barrow. The expedition was a success, and the leaders in it, First Lieut. D. H. Jarvis, Second Lieut. E. P. Bertholf, and Surg. S. J. Call, were awarded gold medals and the thanks of Congress. On December 16, 1897, Lieutenant Jarvis and his companions started from a point some 300 miles south of St. Michael and proceeded northward, first with dog teams and later partly with reindeer and partly with dogs. Some distance above Nome the herd of a native, Charlie Antisarlook by name, was secured. Charlie had been an apprentice at the Government reindeer station and had beeome a skillful manager of the deer. At Cape Prince of Wales a herd of nearly 300 animals, belonging to private parties, under the management of W. T. Lopp, was 
secured, and Mr. Topj) volunteered to drive them to Point Barrow, a distance of 800 miles. They were to be used for food to surene the 300 whalemen who had been lrozen in at that point withont sufficiont provisions. The hardships of this trip throuerh a barren, unpeopled country, with the temperature from $200^{\circ}$ to $500^{\circ} \mathrm{F}$. holow zero, and blizzards raging much of the time, can he better imacrined than described. The undortaking was a suceess. That the deel' could be driven through such a rountry in larea number, find their own food, arrive sately at the destination, and there drop a large number of healthy fawns is evidence of the value of the reindeer to people who live in the Aretics. Dogs must anry their food with them: remdeer serape the snow away and feed on the moss they find undermeath. Numerous other tests lave been made, though less severe. Reindeer have been employed to cal'ry the mail for' several winters between the settlements scatterod along Bering sea. In short, it has been proved to the satisfartion of crery fair-minded person who has taken the trouble to post himsell on the subject that reindeer are an unqualificd success, both as a moans of transportation and as a source of supplies for most of the necessities of life in that region.

\section{TUNGUSF DEER.}

In that portion of northeastern Siberia which is contiguous to the Sea of Okhotsk lives a tribe known as the "Tumguse people." Reindeer breeding appears to be their main industry, and their deer are of a much larger type than those found either in Lapland or Kamchatia. To introduce a stock of these deer in Mlaska Lieut. E. P. Bertholf, of the Rerenue-Cutter Sorviee- the same gentlenan who had accompanied Lientenant Jarvis on the expedition to Point Barrowwas sent to Siberia in the spring of 1901. The traveled from New York to St. Petersburg and 6,000 miles across Russia and Siberia to his destination. It was an eventful and interestine trip. I few quotations from his report to Doctor Jackson, published in the latter's report for 1901, will serve to give an idea of the kind of dere he was after and the way the natives use them:

These Tunguse deer were big follows * * * and they sterk lo their work steadily. Notwithstanding the diffeulties, we made excellent time; and by 2 p. m. we had gome some 12 miles, ineluding 7 miles of roal breaking. Here we came upen a lea cararan of 40 sleds and $100 \mathrm{~d}$ eer that had been stalled for three days by l lae storm. * * * The deer in this part of the country are very much domestiented and tame, and whe 1 he g are allowed to feed the drivers never tether them, lut turn them loose to wander as they wiil. When ready for a start one man romeds the dere up and drives them lo camp, where the: rest surround them and inclose the herel with a long hiche line, which is strelehed alorg between the men. The animals stand very quiotly whilo some of the drivers piek up the halter lines that have beren trailing in the snow, and the derer are then bed for the diflerer:t sleds and harnessed. I never saw an oerasion on our whole route when it was necestary to lasso a deer. When traveling the driver uses a swileh with which to lomels up a lazy decr. 
Again he says:

The Tunguse deer are eertainly magnifieent animals, for they ean earry a full-grown man several miles through very deep snow. In fact, when we were sighted from this eamp, two Tunguse came out to meet us, riding deer that at times sunk in the snow nearly to the sh vulder. The Tunguse who own reindeer do not remain long in one place, for they are of necessity wanderers, being obliged to slift eamp frequently to keep their deer (n) good feeding ground. In these shiftings about the deer are utilized not only as draft, but as pack animals, particularly when the snow is deep.

Speaking of their use for freighting, he says:

During the winter over 1,000 sleds leave Ola at different times, bound for Cemechan, in caravans of about 100 each. With a caravan of about 100 sleds belonging to one out fit there would be about 10 men, each man managing a train of 10 sleds, he driving the head team, while the other teams are tied by their halter lines to the sled in front. As each sled has two deer, and each train extra deer for emergeneies, it will be seen that some 2,500 reindeer are used on this caravan route. Fifteen poods ( 510 pounds) per sled makes a total of at least 15,000 poods (270 tons); and as the difference between the cost of the deer caravans from Ola and the old horse caravans from Yakutsk, both bound to the same place, is $\$ 4$ a pood, orer $\$ 60,000$ is saved to the Government yearly by the establishment of this deer caravan route from Ola to the Kolima River.

Concerning their use as pack animals, he says:

During my travel in the winter I had seen the rcindeer used extensively with the saddle, especially in deep snow: but while I had noted their oceasional use as pack animals, it was by no means general. Now, however, in the summer, I found they were used entirely as beasts of burden. In winter, when sleds ean be used, two deer draw a load of from 15 to 20 poods, or from 540 to 720 pounds, thus transporting from 270 to 360 pounds per deer. That amount is not considered excessive, and the animals plod along with such a load day after day. When used as a pack animal, 150 pounds are considered the proper weight for the pack, though some animals can carry 200 pounds and more.

After much trouble Lieutenant Bertholf succeeded in purchasing 428 head of these large deer, and a ship was chartered to bring them to Alaska. However, owing to rough weather, 174 of these deer died or were killed on the voyage, and only 254 were landed at Teller Reindeer Station, Port Clarence.

TRAINING THE DEER.

Reindeer are naturally wild, and it takes much time, patience, and skill to train them so they can be handled without much trouble. Their wildness is in large measure due to the fact that they are usually bred in large herds, and individual animals are therefore not aceustomed to be handled by the herders, who confine their attention in this respect to the few trained sled deer. The training begins when the deer is 3 years old. Generally the stoutest males and geldings are selected. Females are also trained, but they are smaller and less enduring. The training begins by lassoing the selected animals, thus separating them from the herd. The poor beasts are much scared, and jump about in frantic efforts to escape. The trainer advances hand over hand on the rawhide lasso till the head is reached. They 
are then sometimes given a little salt, of which they are lomd; they are then led about for some time or tied to a post to acesstom them to confinement and, the lesson over, again released. 'This is repoutrol day hy day, and when suflicienty lamed they ale hamessed and in the same manner gradually aceustomed to draw light loads. This takes a long time and persistent work. They should not he worked before they are 3 years old. At 6 or 7 they reach their prine and then grialually decline.

In regard to driving them, Lieut. 1). H. Jarvis makes the following observation in his report:

All hands must be ready at the same time when starting a deere train, for just as soon as the animals see the head team start they are all ofl with a jump, and for a short time keep up a very high rate of speed. If one is not quick in jumping and holding on to his sled, he is likely eitler to lose his team or to be dragged a long through the snow. They soon come down to a moderate gait, however, and finally drop into a walk when tired.

\section{DEER HARNESS.}

There are at least three ways of harnessing deer-one in Siberia and two in Lapland. Lieutenant Bertholf makes the following observation on the Siberian method:

They are harnessed in pairs by a very sinuple arrangement-a plain loop of rawhide about 2 inches wide that gors over the ofl shoulder and between the forelegs. These loops are made fast to a single piece of rawhide that goes over the bent sapling on the front end of the sled runners, allowing it free motion. This makes both deer pull together, for if one gets ahead the other's hind legs hit against the sled and he is spurred on.

That is, the animal pulls by the left shoulder, the loop or strap referred to passing over the withers and between the legs, as when one ties a sash over the shoulder. The trace is fastened at the right side, at the elbow of the right fore leg: the hind legs are thus both on the left side of the trace. The animal can not pull straight, but must of necessity advance somewhat sidewise. It appears like a barbaric and primitive, not to say cruel, way of working them.

Another method used in Lapland is not very diflerent, but yet an improvement. A broad strap of rawide is placed over the neck: the two ends being lashed together, they are drawn in between the fore legs and fastened to the trace, which passes out between the hind legs and is secured to the sled. The deer thus straddles the trace, and the pressure of the pull comes on the neck just in front of the shoulders and on the brisket.

A more modern style of harness is now also much used in Lapland. Lieutenant Jarvis describes it so fully that I will guote him again. this being the manner in which the deer he used on his Point Barrow trip were harnessed:

They are harnessed with a well-fitting collar of $\mathrm{two}$ flat pieces of wond, fron which a short trace goes back on each side to the ends of a breast pieer, or swingletree, that fits under the body. [It is held up by a strap over the back.] From the conter of o his a single trace runs 
Inack to the sted, either between or on one side of the hind legs. In the wake of the legs this trace is protected with some soft fur, or the skin will be wom through with the constant chafing. Generally there is a single line made fast to the left side of the halter, and with this the animal is guided and held in check.

In Lapland, as in Alaska, there is seldom more than one animal hitched to a sled.

\section{SLEUS.}

There a re two forms of sleds used in Alaska. One is called a " pulka." It is a style which has been used in Lapland for centuries. It is about 7 feet long and 2 feet broad, pointed in front and square in the back, and generally rounded underneath so as to greatly resemble a boat. It has the desirable merits that it pulls easily and does not sink into soft snow. The front half is covered with deerskin strctched over bows. In this receptacle the baggage of the travcler is placed. A partition in the sled makes it a closed box. Access is had through a square hole in the top closed by a tight-fitting lid. In the back half of the sled is an upholstered low seat with back rest. It takes much experience to keep the seat, as the sled rolls from side to side. The other form of the sled is like the dog sled, or hand sled, in common use. It varies very much, as it is largely homemade; it is 9 feet long and 2 feet wide, built of thin slats to make it as light as possible, and inclosed by a railing about a foot high.

\section{PLAN OF DISTRIBLTION OF DEER.}

The object in introducing the deer is to familiarize the Eskimos with their use and to induce them to breed and to handle them. To this end the following plan has been adopted: The Teller reindeer station has been made the headquarters for the Government herd. A general superintendent and the other necessary employees hare been stationed here. A number of expert Lapp reindeer men have been employed, who have the handling of the deer and also act as teachers to the Eskimos. The most intelligent young men from the various villages along the coast have been selected as apprentices to learn the art of breeding reindeer. They enter into an agreement to remain from two to five years or until, in the judgment of the superintendent, they have acquired sufficient skill to handle a herd. Deanwhile they are given rations and clothing and get a nominal pay in deer. If they show a lack of interest or are too dull to learn they are dismissed. When capable to handle them the Government will lend them a few deer, from which they can have the increase, but must return within five years the original number loaned. This gives them a nucleus for a herd. The Govermment also lends herds to mission stations on the same conditions. According to Doctor Jackson's report for 1902 there were then 60 individual owners of 
reindeer in Alaska, $4 t$ of whom were Eskinos. Some of the mision stations have Lapp herdors, who teach the natjest, and where this is the case these missions beeome in eflect powrernl assistants to the Government. This appears to the writer to bo an exerllent plan. It helps the missions and at the same time hastens the arequisition of skill among the natives, which is a prine object. By lending deer to those natives only who have taken an interest in the mattre and who have learned to handle them the danger of loss from enrelessness is reduced to a minimum. The deer owners soen boromes important men in their respertive neighborhoods, and others will strive to emulate them. Tho ownership makes them independent of the ortinary methods of making a living; it teaches them selfrespect and self-reliance. The deer also bring in money. The meat on one of them is worth from $\$ 50$ to $\$ 100$ at the mines, and sled deer are worth upward of $\$ 100$ each.

\section{MISEASES OF REINUEEI?.}

The reindeer is subject to several diseases, and it is very prone to acciclents. In every herd, therefore, there is a certain ammul percentage of losses which seem to be inevitable. One of its afllictions is known as the hoof disease. It begins with a laneness, followed by a swelling near the hoof, though the swelling may appear higher up on the leg or even on other parts of the body. 'The swelling is follower! by the formation of pus, which may result in a ruming sore, followed by gradual recovery after several months; or the disease may become systemic, when the animal usually dies. Dr. F. II. Gambell, superintendent of the Eaton reindeer station, writes as lollows on the subject:

Iiy belief is that the disease originates in the bones, generally wear the art iculation: that the inflammation is due to pus-produeing gorms, which find lodgrnem in the devianlized bon.: that gradually the pus "works" Io the surface, cansing an open sore: that at this time the trouble is localized, but later may become systemic.

Doctor Gambell has noticed a craving for calcium salts, and adranees the theory that the disease is due to lack of vitality, owing to the great strain upon the system to grow the antlers in so short a time. It might be inferred that giving them access to lime in some form would have a tendency to remedr the evil, but no (axperinents on that point are reported.

Reindeer are also subject to another trouble, designated as liverand-lung disease, from which it appears that many have died in the Government herd. No remedy has been reported.

They are prone to aceident, and many deer break their leces, their necks, or their backs while rumning about or while fighting with each other. 
IMPROVING THE BREED.

It appears to the writer that much could be done in the way of improving the size and strength of the animal, and therefore its usefulness, by breeding them up. The laws of breeding which hold sway in the development of eattle, sheep, and hogs, nust likewise be applicable in the breeding of reindeer. Is has been noted, many of the wild deer are larger than the domesticated, probably because in the former ease nature has applied her laws of the survival of the fittest, and the strongest males of the herd, as a rule, have become the sires of the herd. Tnder domestication these laws could be applied to even better advantage and doubtless with good results.

The abortion of the antlers, which under domestication are not only utterly useless, but a decided disadvantage to the animal, is another line in which experiment might be tried with interesting results.

\section{REINDEER ANI AGRICLLTURE INCONPATIBLE.}

The zone of the usefulness of the reindeer lies wholly outside that in which agriculture is possible. It lives ehiefly on the lichen and herbage indigenous to the region where no agrieultural plants will grow. It will not thrive in the warmer regions where agriculture is practicable, and it can not live on the kind of forage which we feed to eattle and horses. Wherever the ground can be cultivated its place will be taken by the horse and ox. But it is by far the most useful animal for the region north of the agricultural belt. It is the means of transmuting a rast amount of regetation into meat and skins necessary to the support of the Eskimos. 


\section{IN D F X .}

1 ate.

1:31

114

+1. IHi

$4-2$

11ti- -1

1.9. 9!

t른

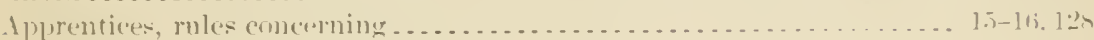

Stumler of, with thejr holeliugs...........................

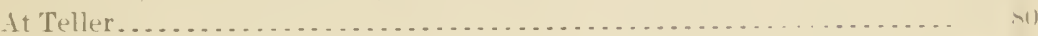

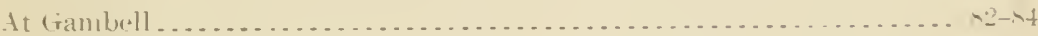

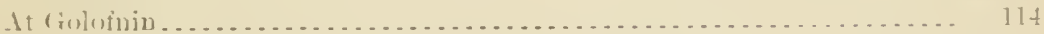

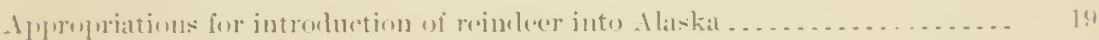

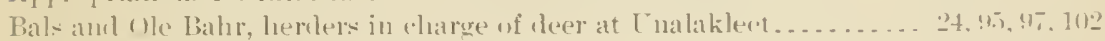

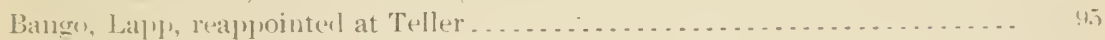

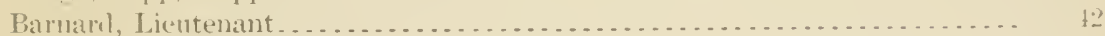

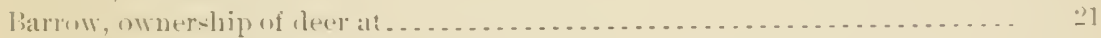

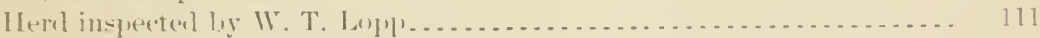

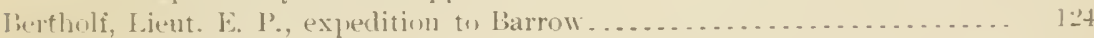

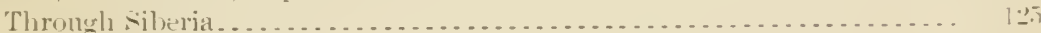

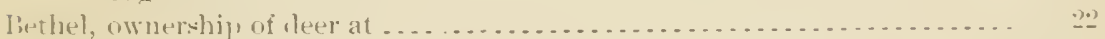

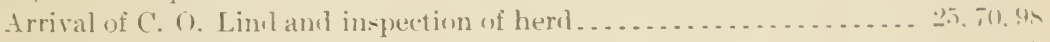

Repurt of superintendent . . . . . . . . . . . . . . . . . . . . . . .

lietles. establishment of station at . . . . . . . . . . . . . . . . . . . . . . .

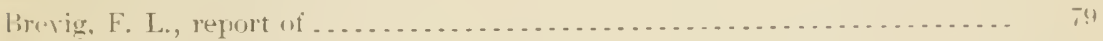

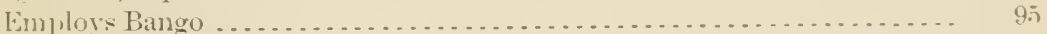

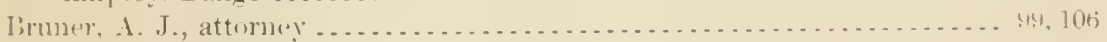

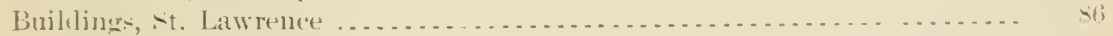

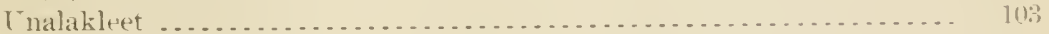

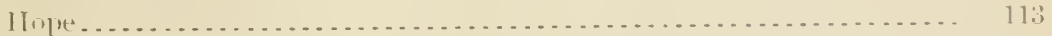

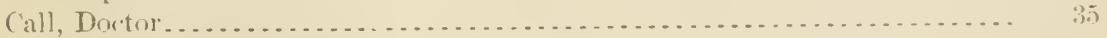

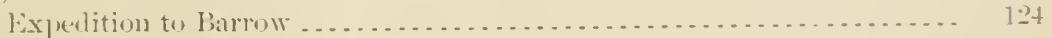

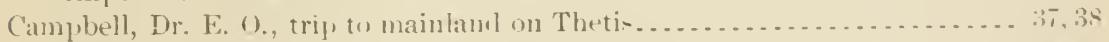

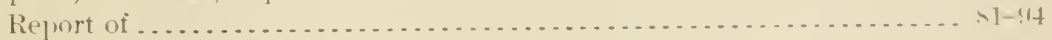

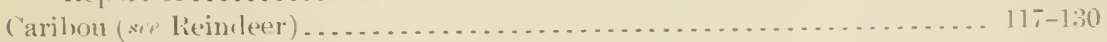

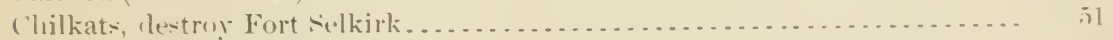

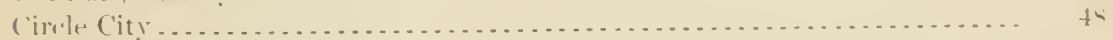

(immisioner of education; ioruatols reimleer report to the seceretaly of the Interior

Repuests feeretary of the Treasury for transportation wh revelnu "inter.

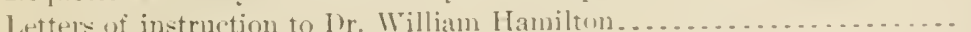

Telesraphs to postpone trial of Mary Antisartook. 
Copper Center, station established at ........................... 17

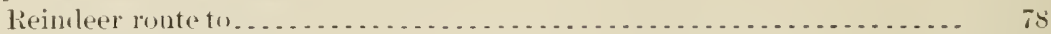

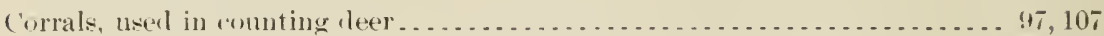

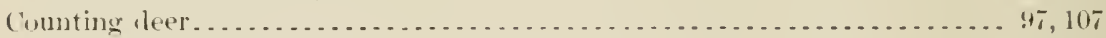

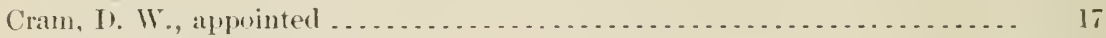

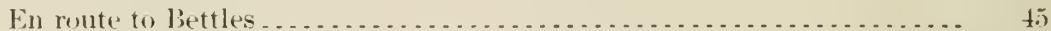

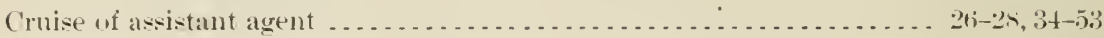

Dawson.......... . . . . . . . . . . . . . . . . . . . . . . . . . . . . . . 49

Disease of reimleer ... . . . . . . . . . . . . . . . . . . . . . . . . . . . . . . . 129

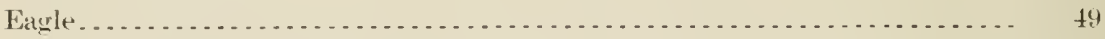

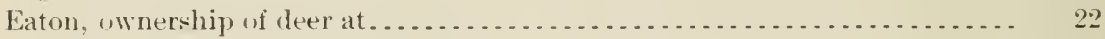

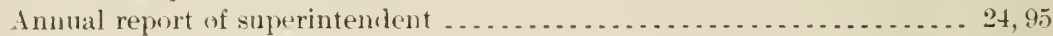

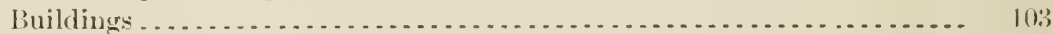

Education. (sereshools.)

Exkimu, civilization of (see Natives) ... . . . . . . . . . . . . . . . . . . . 12-16

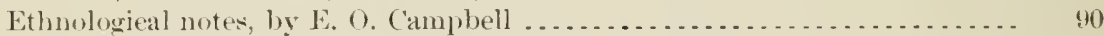

Expenditures of appropriation, "Reindeer for Alaska, 1904" . . . . . . . . . 19

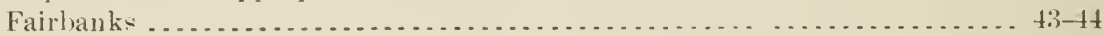

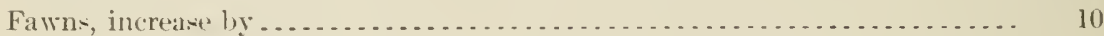

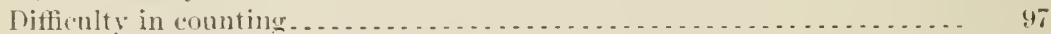

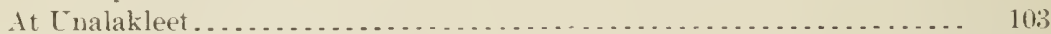

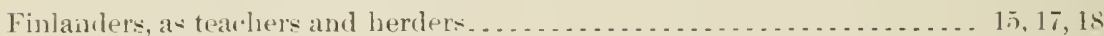

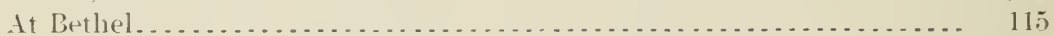

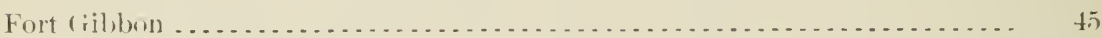

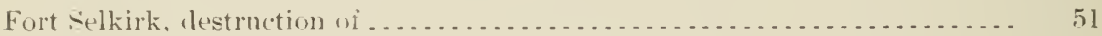

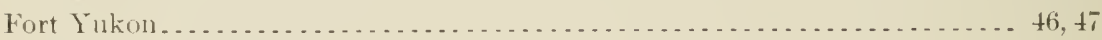

Freighting. (Ser Reindere)

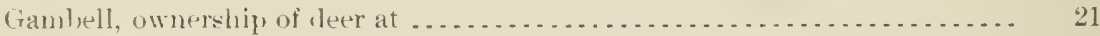

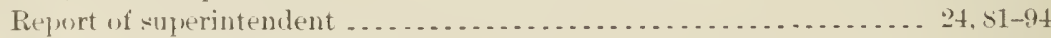

(iambell, Dr. F. H., on hoof disease............................. 129

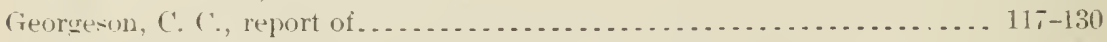

Gold, on creeks and tributaries of Tanana. . . . . . . . . . . . . . . . . . . 43

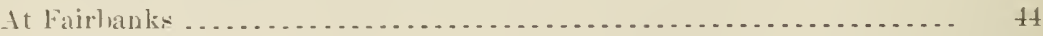

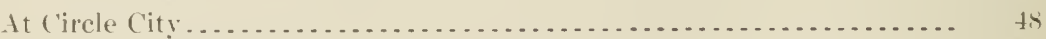

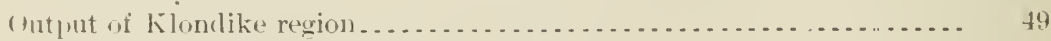

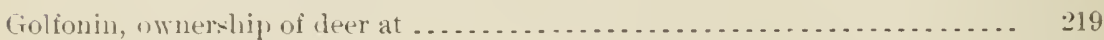

Insperted ly $($. O. Lind . . . . . . . . . . . . . . . . . . . . . . . . . . . 102

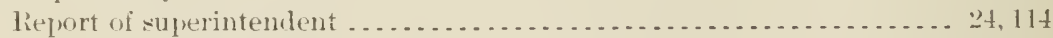

Govermment, deer belonging to . . . . . . . . . . . . . . . . . . . . . . . .

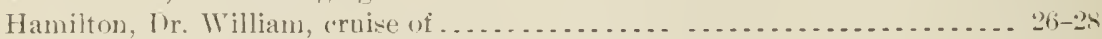

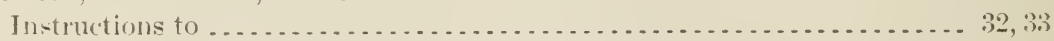

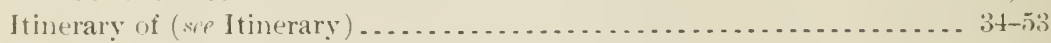

Ilarnes. . . . . . . . . . . . . .

Harris, Dr. IV. T. (Ne Commissioner of Elucation.)

Herlers. (Sie Natives and apprentices.)

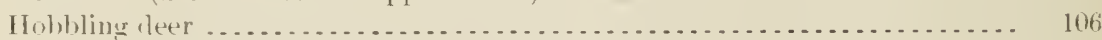

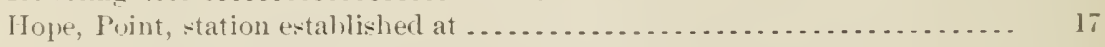

Tixit of IV. T. Lopl' ...................................... 111

Horses and mules eompared with reindeer . . . . . . . . . . . . . . . . 10.5

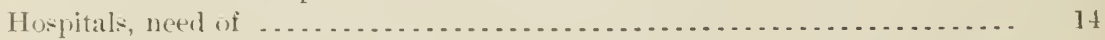

Hudson Bay (1)., at Furt lukon .............................. 46

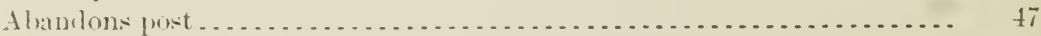

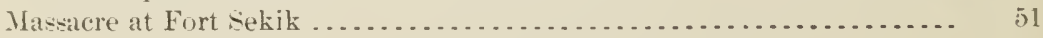


P'are.

Fkngmut (Russian mission)

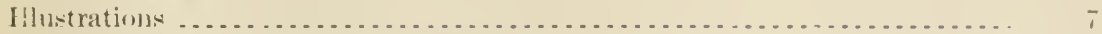

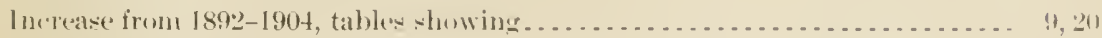

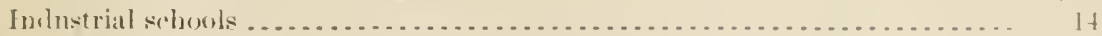

I'se of reindere in .................................... 11

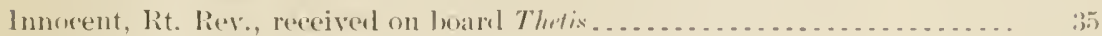

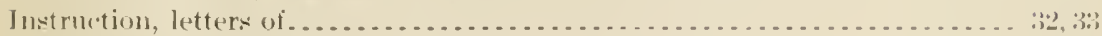

Itinerary of Doctor Hamilton:

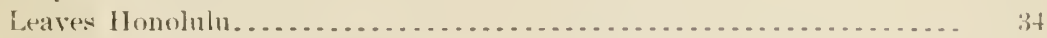

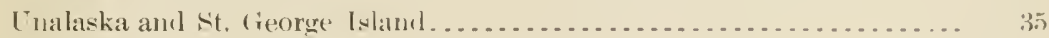

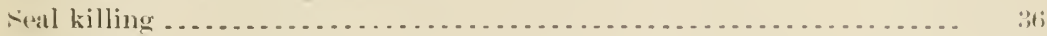

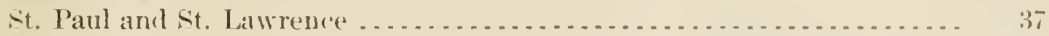

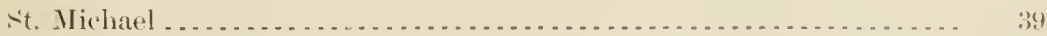

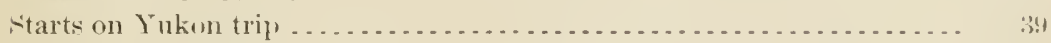

The Yukon rlescriberl. . . . . . . . . . . . . . . . . . . . . . . . . . . .

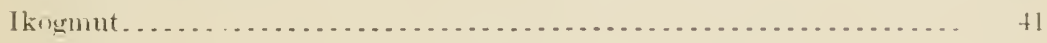

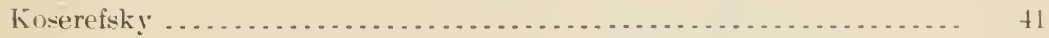

Nulato ............................................ t2

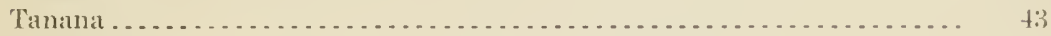

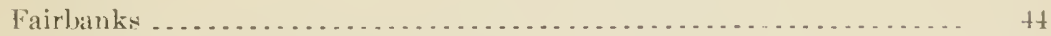

Fort Gibbon, St. James Misisjon, Tatnana. . . . . . . . . . . . . . . . . t. th

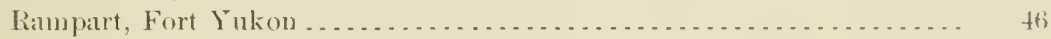

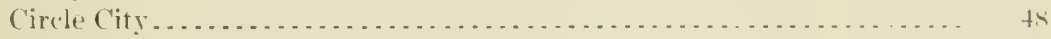

Fayle...................................... th

Irawion ....

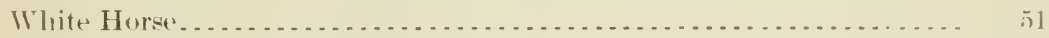

Skagway, Juneau, Sitka, and San Francicon . . . . . . . . . . . . . . . 5.

Jackwon, Doctor Shelklon, annual report . . . . . . . . . . . . . . . . . .

Comeetion with introluction of reindeer into Alakka ... . . . . . . . . 12.3-1:t

Jarvis, Lieut. D. H., relief experition to Barrow . . . . . . . . . . . . . . . . 1:24

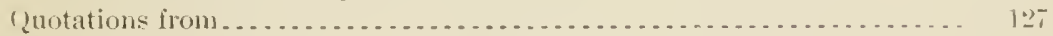

Jaslıer, J. H., appointed . . . . . . . . . . . .

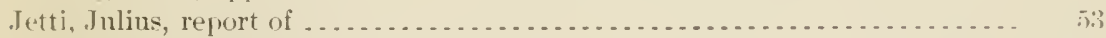

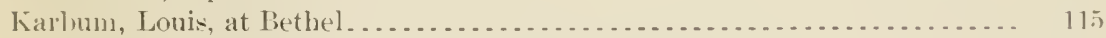

Kilburk, John H., placed in cluarge of Wainw right . . . . . . . . . . . . . . 17

Arrival at Barmw . . . . . . . . . . . . . . . . . . . . . . . . . . . . 111

Kjellinan, W. A., letter concerning route jom Bethel to Coppere Center..... T.

Trij of 2,000 niles . . . . . . . . . . . . . . . . . . . . . . . . . . . . . . .

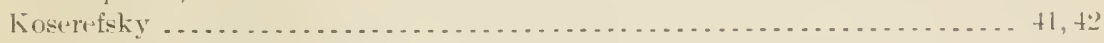

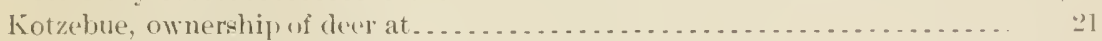

Inspected hy C. (). Lind................................... 10. . . .

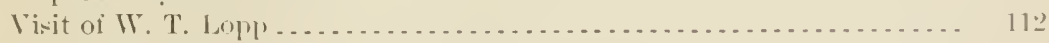

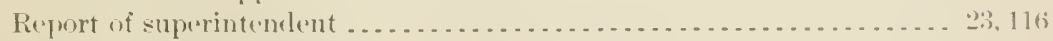

Kuskukwim. (see liethel.)

Laplanters, as instructors . . . . . . . . . . . . . . . . . . . . . . . . 15, 1:4

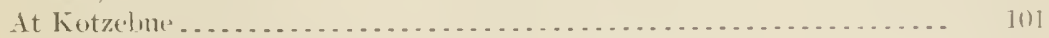

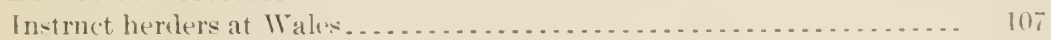

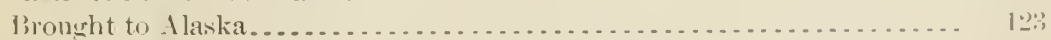

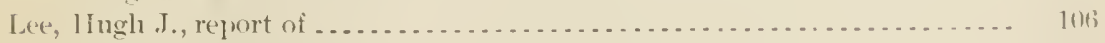

Lind, C. (0., tonl of inspection ... . . . . . . . . . . . . . . . . . . . . . .

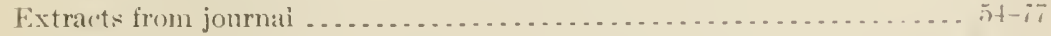

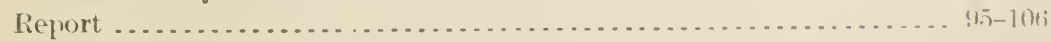

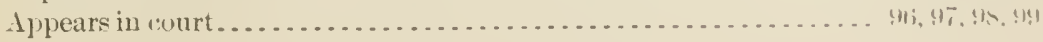


Lind, (. (), tour of inspection-Continnerl. Prge.

Arrives at livthel . . . . . . . . . . . . . . . . . . . . . . . . . . . . . . . 48

Arrives at Kotzebue . . . . . . . . . . . . . . . . . . . . . . . . . . . . . 101

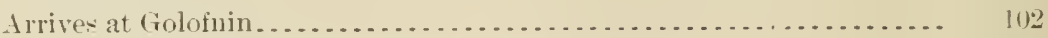

Arrives at Unalaklet. . . . . . . . . . . . . . . . . . . . . . . . . . 102

Lindseth, J. T., brings suit aqainst Mary Antisarlook . . . . . . . . . . . .

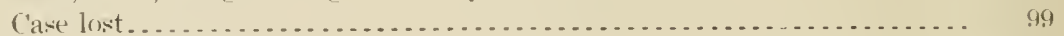

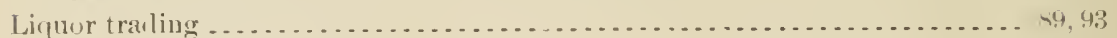

Loans of lewr, tahle showine. . . . . . . . . . . . . . . . . . . . . . . . . .

lopp, II. T., appointed superintendent ..................... 17, Is

Letter of . . . . . . . . . . . . . . . . . . . . . . . . . . . . . . . . . 1017

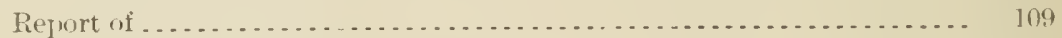

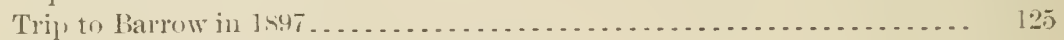

Mail carried by reindeer teams (st Reindeer).

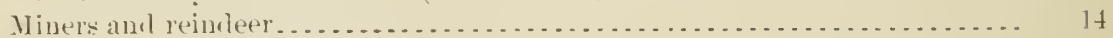

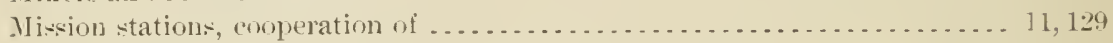

Loans to . . . . . . . . . . . . . . . . . . . . . . . . . . . . . . . . . 12

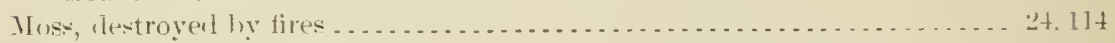

Nallogoroak, trip to Bethe] ... . . . . . . . . . . . . . . . . . . . . . . .

Natives, as asistants in development of Alaska. . . . . . . . . . . . . . . . . 12-16

Numler obtaining supjort from deer . . . . . . . . . . . . . . . . . . . 11;, 104

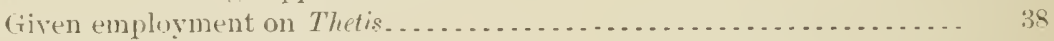

Employmentis on Yukon... . . . . . . . . . . . . . . . . . . . . . . . . . $411-41$

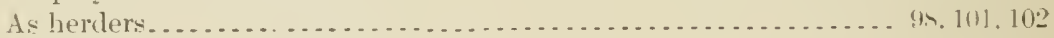

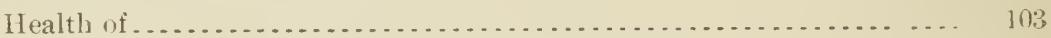

Nilina, clicf lierder at Kotzebut... . . . . . . . . . . . . . . . . . . . . 1111

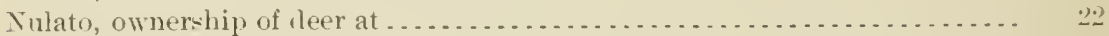

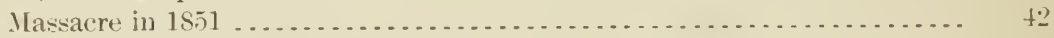

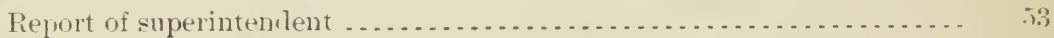

Persomel of reindeer service . . . . . . . .

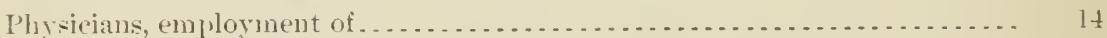

Pust-Office Department, mail routes established by . . . . . . . . . . . . . . . 13, 17

Presirlent's message calls attention to 1 laska . . . . . . . . . . . . . . . . . 12

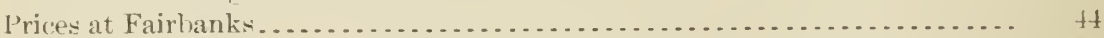

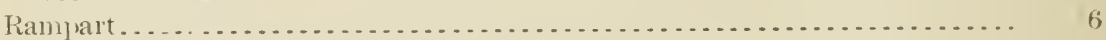

Redmiver, 11. E., to drive herds to Copper (enter. . . . . . . . . . . . . . . . 17

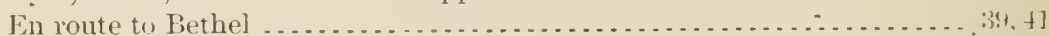

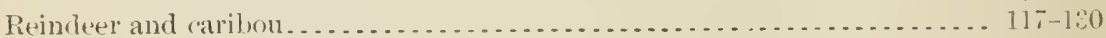

Important factor in the civilization of the Eskimos . . . . . . . . . . . 12-16

Ability to travel . . . . . . . . . . . . . . . . . . . . . . . . . . . . . . . 105

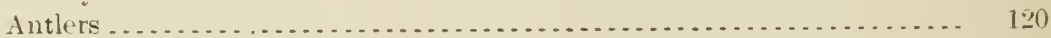

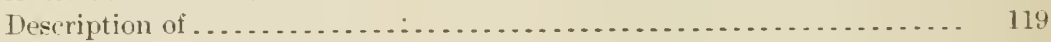

Hiseises of . . . . . . . . . . . . . . . . . . . . . . . . . . . . . . . . . . 129

Dog teams compred with reindeer teams..... 24, 25, 100, 102, 104, 105, 114, 116

Domesticated . . . . . . . . . . . . . . . . . . . . . . . . . . . . . . . . 121

Freighting with . .............................. 99. 100, 105, 114, 116

In Siberia........................................... 126

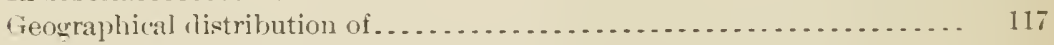

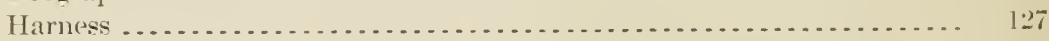

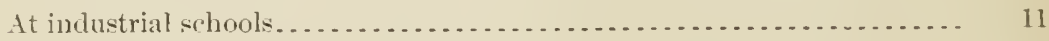

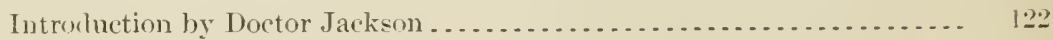

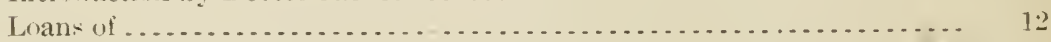

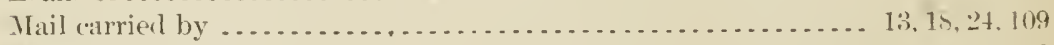

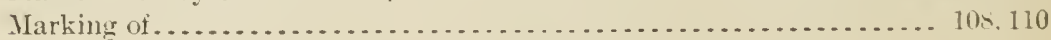


Reimlexp anul raribnn-cintinnexl.

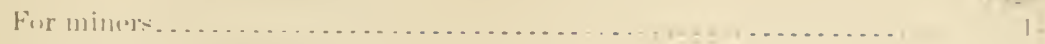

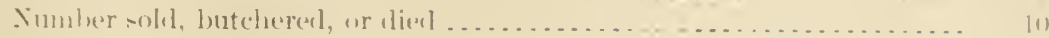

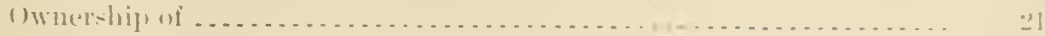

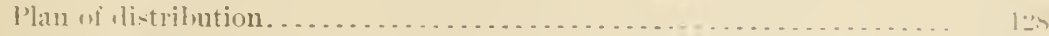

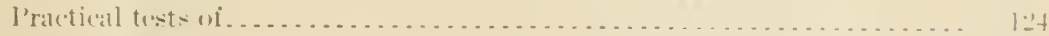

Rule and regulations concerning . . . . . . . . . . . . . . . 111, 1:. 15, 11;, 1:3)

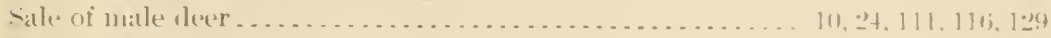

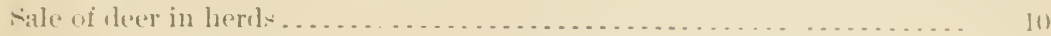

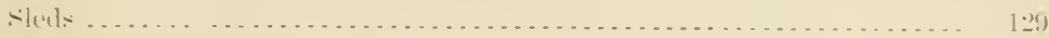

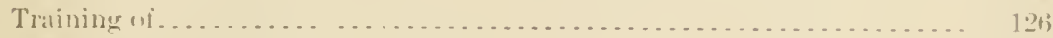

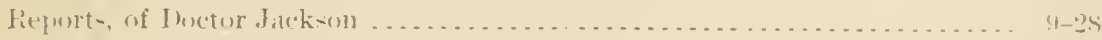

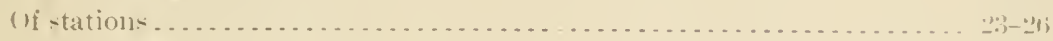

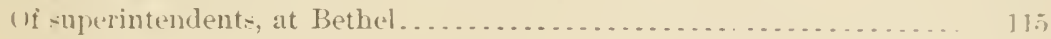

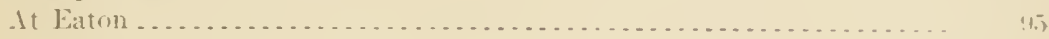

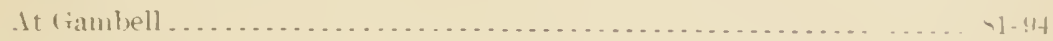

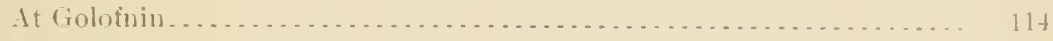

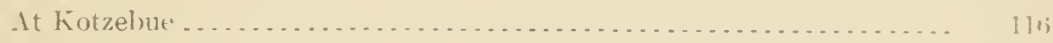

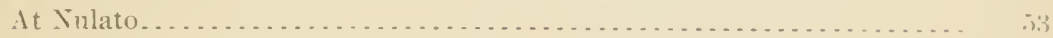

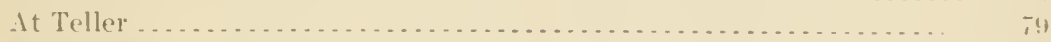

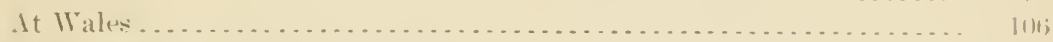

Request to seretary for transportation. . . . . . . . . . . . . . . . . .

Richarls. Thumas, assistant to Buctor Campbell ... . . . . . . . . . . . . .

Efticivut management wi ajprentice. . . . . . . . . . . . . . . . . . .

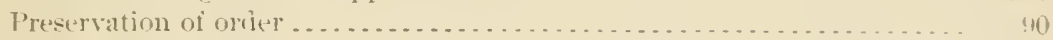

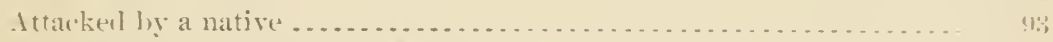

Rowe, Bislıol, P. T., hospitals erectel ly. . . . . . . . . . . . . . . . . .

Rules :mil regulations (see Reindeer).

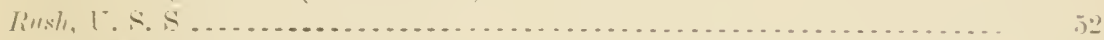

Rusian-Aneric an Fur Company on the Yukon .................... ti

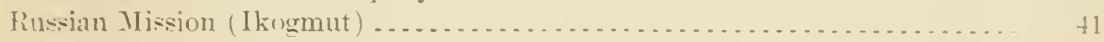

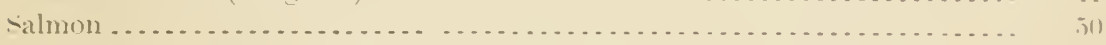

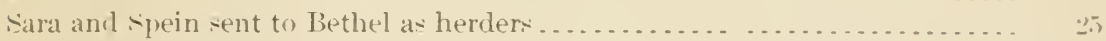

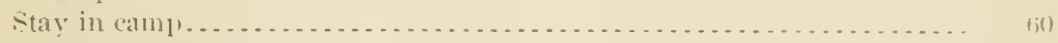

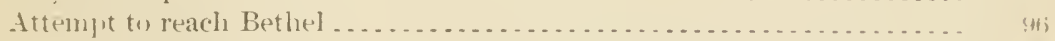

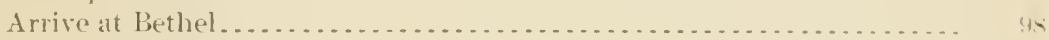

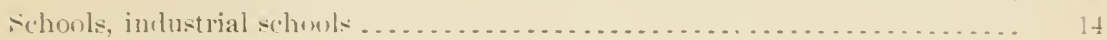

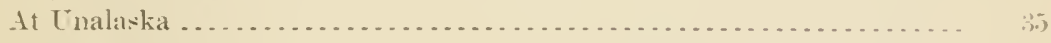

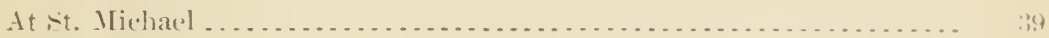

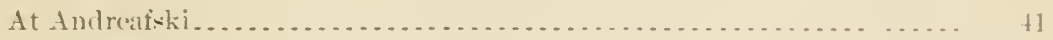

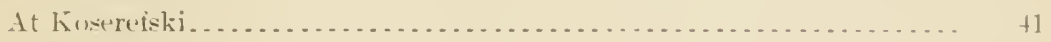

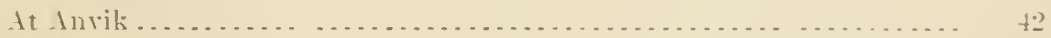

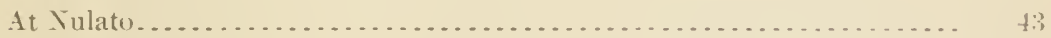

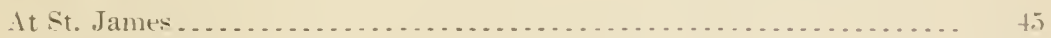

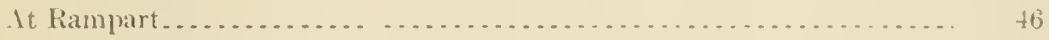

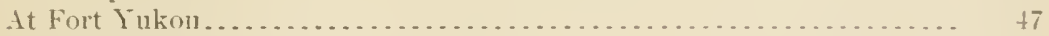

At Dawson. . . . . . . . . . . . . . . . . . . . . .

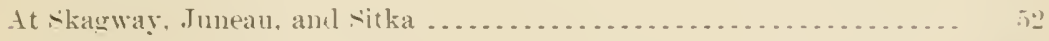

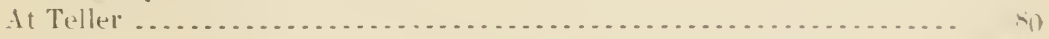

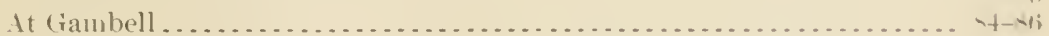

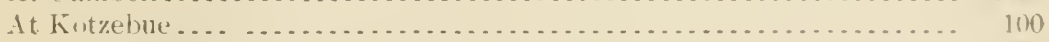

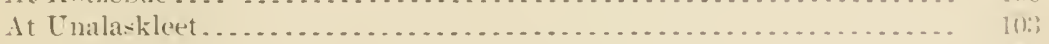

At Shishmaref . . . . . . . . . . . . . . . . . . . . .

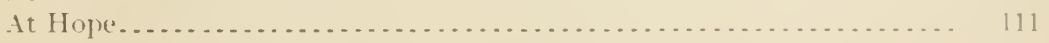

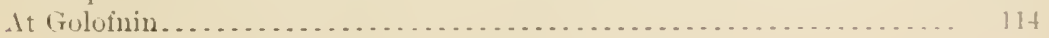




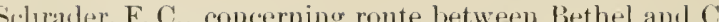

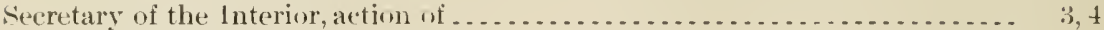

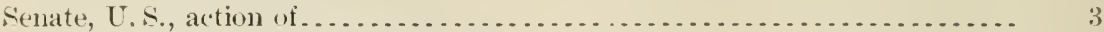

Serawlook, applentice, drives nuil teams . . . . . . . . . . . . . . . . . . . 24

Sex of rleer in herds, table showing ............................... 10

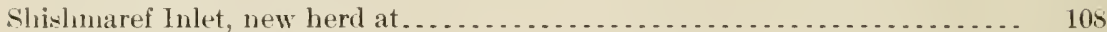

fichool needed at ......................................... 109

Siberia, visits of Doetor Jackson to... . . . . . . . . . . . . . . . . . . . . . 123

Experlition of Lientenant Bertholf. . . . . . . . . . . . . . . . . . . 125

Signal Corps, use huilding at Eaton. . . . . . . . . . . . . . . . . . . . . . 10.3

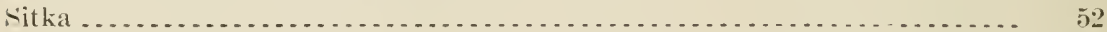

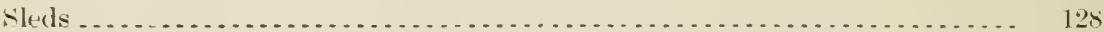

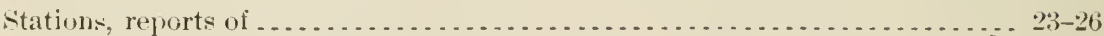

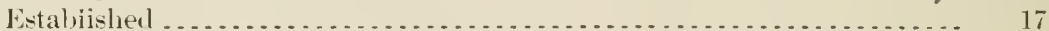

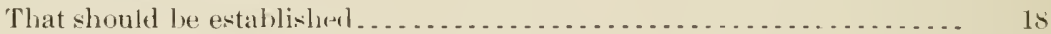

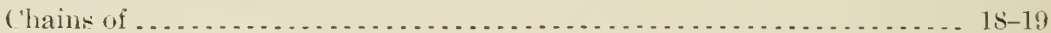

IV. T. Lopl's opinion of proposed stations . . . . . . . . . . . . . . . . 10 s

Sterker, A., receives Doctor Lind................................ 70

Informed of plans to move herds. . . . . . . . . . . . . . . . . . . . . . 96

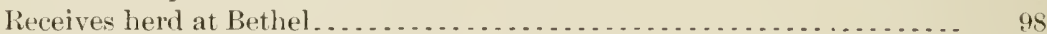

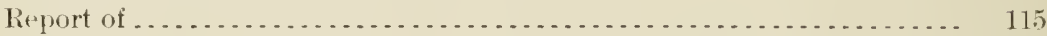

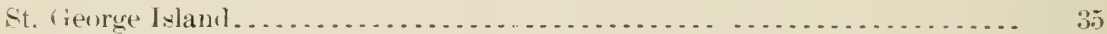

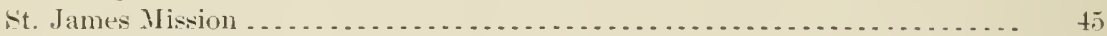

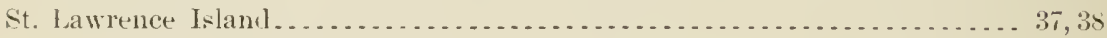

Report of station on . . . . . . . . . . . . . . . . . . . . . . . . . . . $81-94$

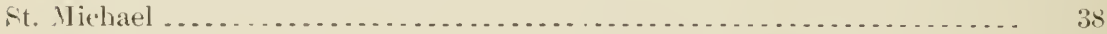

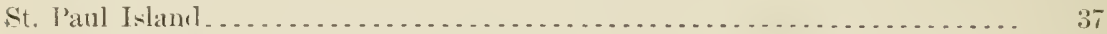

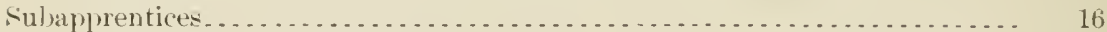

Superintendents, aplointerl (se heports) . . . . . . . . . . . . . . . . . . . 1 .

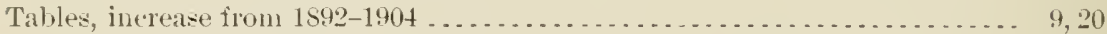

Increase of fawns . . . . . . . . . . . . . . . . . . . . . . . . . . . . . . . 10

Number of deer sold, butchered, or lied . . . . . . . . . . . . . . . . . 10

Sex of deer in herds ... . . . . . . . . . . . . . . . . . . . . . . . . . . . . . . . 10

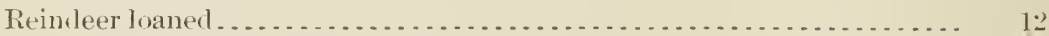

Number of apprentices with their holkings...................... 16

Congressional appropriations................................. 19

(1)nership of deer...................................... 20

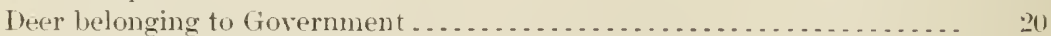

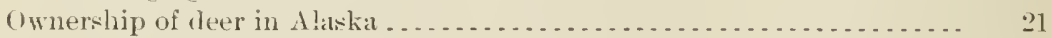

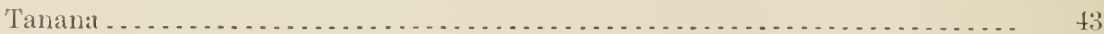

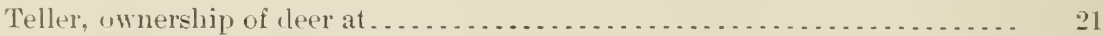

Rejurt of superintendent ................................... 4 .

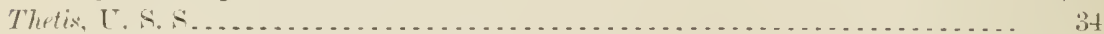

Thomas, Dana, entertains Inetor Lind ........................... 100

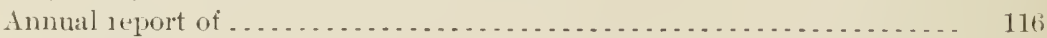

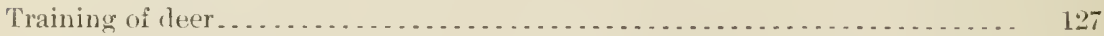

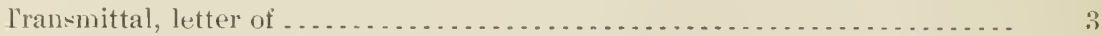

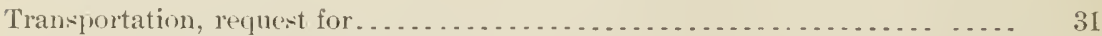

Treasmy Department, copperation of . . . . . . . . . . . . . . . . . . . .4, 52, 113

(irants permission for transportation . . . . . . . . . . . . . . . . . .

Tunguve leer . . . . . . . . . . . . . . . . . . . . . . . . . . . . . . . . . . 125

Unālakleet, report of herd at (see Eaton) ... . . . . . . . . . . . . . 102-103

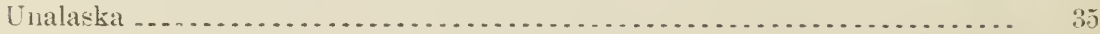


Yegetables, grown at Kinserefisy

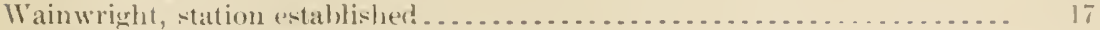

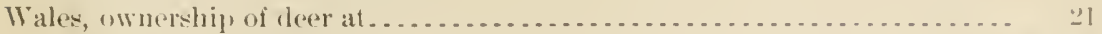

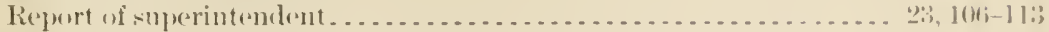

Mail route to.............................................. I lo

Walrus, fish, etr..................................................

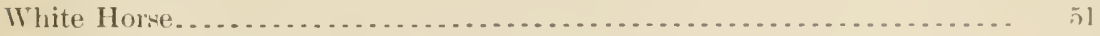

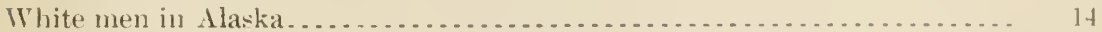

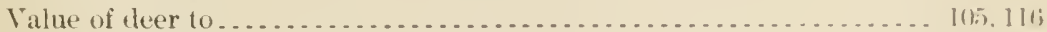

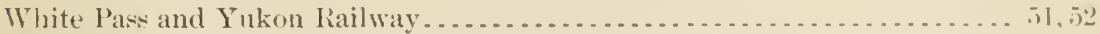

IVillard, F. E., en route to Fort Yukon......................... ti

Yukon River deseribed ........................................

$\mathrm{O}$ 







\section{UNIVERSITY OF CALIFORNIA LIBRARY}

Los Angeles

This book is DUE on the last date stamped below.

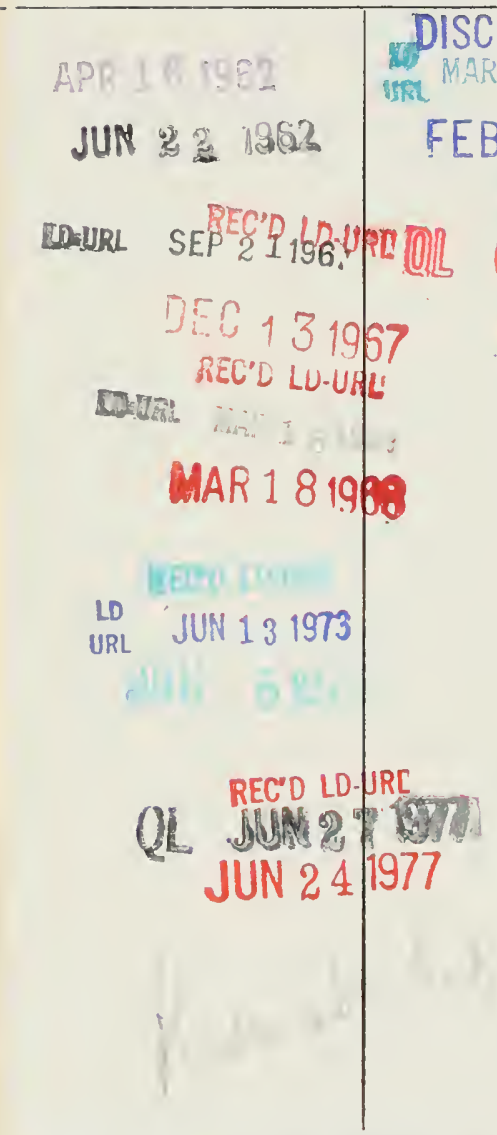

Form L9-20m-9,'61 (C3106s4) 444 
